Prepared in cooperation with the U.S. Department of Energy, National Nuclear Security Administration Nevada Site Office, Office of Environmental Management under Interagency Agreement DE-A152-07NA28100

\title{
Groundwater Withdrawals and Associated Well Descriptions for the Nevada National Security Site, Nye County, Nevada, 1951-2008
}

Data Series 567 



\section{Groundwater Withdrawals and Associated Well Descriptions for the Nevada National Security Site, Nye County, Nevada, 1951-2008}

By Peggy E. Elliott and Michael T. Moreo

Prepared in cooperation with the U.S. Department of Energy, National Nuclear Security Administration Nevada Site Office, Office of Environmental Management under Interagency Agreement DE-A152-07NA28100

Data Series 567 


\title{
U.S. Department of the Interior \\ KEN SALAZAR, Secretary \\ U.S. Geological Survey \\ Marcia K. McNutt, Director
}

\author{
U.S. Geological Survey, Reston, Virginia: 2011
}

For more information on the USGS - the Federal source for science about the Earth, its natural and living resources, natural hazards, and the environment, visit http://www.usgs.gov or call 1-888-ASK-USGS.

For an overview of USGS information products, including maps, imagery, and publications, visit http://www.usgs.gov/pubprod

To order this and other USGS information products, visit http://store.usgs.gov

Any use of trade, product, or firm names is for descriptive purposes only and does not imply endorsement by the U.S. Government.

Although this report is in the public domain, permission must be secured from the individual copyright owners to reproduce any copyrighted materials contained within this report.

Suggested citation:

Elliott, P.E., and Moreo, M.T., 2011, Groundwater withdrawals and associated well descriptions for the Nevada National Security Site, Nye County, Nevada, 1951-2008: U.S. Geological Survey Data Series 567, 126 p. 


\section{Contents}

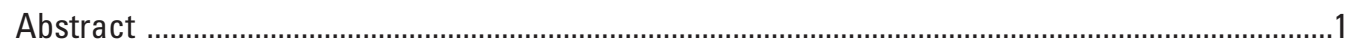

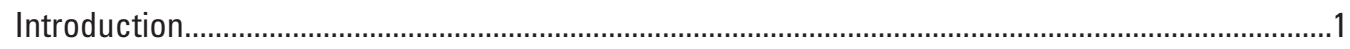

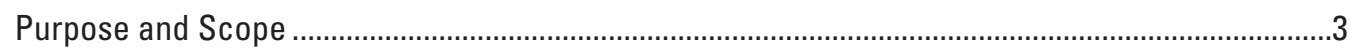

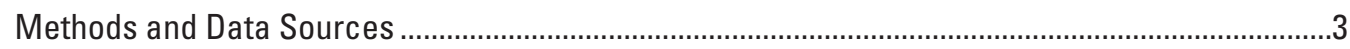

Groundwater Withdrawals for the Nevada National Security Site ................................................

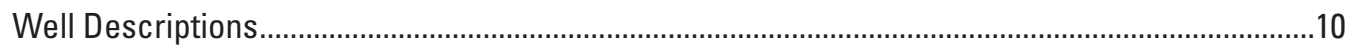

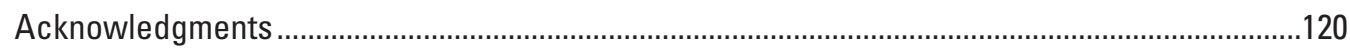

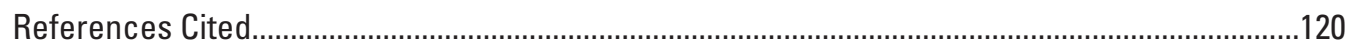

Appendix A. Database of Groundwater Withdrawal Data and Associated Well

Characteristics for the Nevada National Security Site, Nye County, Nevada, 1951-2008

\section{Figures}

Figure 1. Map showing boreholes used for water withdrawal in support of Nevada National Security Site activities, Nye County, Nevada ..........................

Figure 2. Screenshot of Microsoft ${ }^{\oplus}$ Excel graphics showing how to access groundwater withdrawal data and well characteristics interactively for wells and a site map showing borehole locations on and adjacent to the Nevada National Security Site, Nye County, Nevada ............................... 8

Figure 3. Graph showing annual groundwater withdrawals for the Nevada National Security Site, Nye County, Nevada, $1951-2008$...............................

Figure 4. Graph showing groundwater withdrawals by region on the Nevada National Security Site, Nye County, Nevada, 1951-2008

Figure 5. Diagram showing lithologic patterns and units used in the lithology diagrams for wells on and adjacent to the Nevada National Security Site, Nye County, Nevada

Figure 6. Diagram showing borehole lithology and well construction for well Army 1 WW (MV-1), Area 22, Nevada National Security Site, Nye County, Nevada ........ 13

Figure 7. Graphs showing annual groundwater withdrawals and water levels for well Army 1 WW (MV-1), Area 22, Nevada National Security Site, Nye County, Nevada, 1962-2008

Figure 8. Diagram showing borehole lithology and well construction for well ER-6-1-2 main, Area 6, Nevada National Security Site, Nye County, Nevada ............... 16

Figure 9. Graphs showing annual groundwater withdrawals and water levels for well ER-6-1-2 main, Area 6, Nevada National Security Site, Nye County, Nevada, $2002-08$

Figure 10. Diagram showing borehole lithology and well construction for well J-11 WW, Area 25, Nevada National Security Site, Nye County, Nevada.

Figure 11. Graphs showing annual groundwater withdrawals and water levels for well J-11 WW, Area 25, Nevada National Security Site, Nye County, Nevada, 1957-2008

Figure 12. Diagrams showing borehole lithology and well construction for wells $\mathrm{J}-12$ $W W(885 \mathrm{ft})$ and $J-12$ WW, Area 25, Nevada National Security Site, Nye County, Nevada 


\section{Figures-Continued}

Figure 13. Graphs showing annual groundwater withdrawals and water levels for wells J-12 WW (885 ft) and J-12 WW, Area 25, Nevada National Security Site, Nye County, Nevada, 1957-2008

Figure 14. Diagram showing borehole lithology and well construction for well J-13 WW, Area 25, Nevada National Security Site, Nye County, Nevada ................... 26

Figure 15. Graphs showing annual groundwater withdrawals and water levels for well J-13 WW, Area 25, Nevada National Security Site, Nye County, Nevada, 1962-2008

Figure 16. Diagram showing borehole lithology and well construction for well RNM-2S, Area 5, Nevada National Security Site, Nye County, Nevada

Figure 17. Graphs showing annual groundwater withdrawals and water levels for well RNM-2S, Area 5, Nevada National Security Site, Nye County, Nevada, 1974-2008

Figure 18. Diagram showing borehole lithology and well construction for well U-20 WW (cased), Area 20, Nevada National Security Site, Nye County, Nevada 32

Figure 19. Graphs showing annual groundwater withdrawals and water levels for well U-20 WW (cased), Area 20, Nevada National Security Site, Nye County, Nevada, 1982-2008

Figure 20. Diagram showing borehole lithology and well construction for well U-20a 2 WW, Area 20, Nevada National Security Site, Nye County, Nevada

Figure 21. Graphs showing annual groundwater withdrawals and water levels for well U-20a 2 WW, Area 20, Nevada National Security Site, Nye County, Nevada, $1964-76$

Figure 22. Diagrams showing borehole lithology and well construction for wells U-20n PS 1DD-H (4309 ft), U-20n PS 1DD-H (3025 ft), and U-20n PS 1DD-H (recompl),

Area 20, Nevada National Security Site, Nye County, Nevada

Figure 23. Graphs showing annual groundwater withdrawals and water levels for wells U-20n PS 1DD-H (4309 ft), U-20n PS 1DD-H (3025 ft), and U-20n PS 1DD-H (recompl), Area 20, Nevada National Security Site, Nye County, Nevada, 1983-2008

Figure 24. Diagram showing borehole lithology and well construction for well UE-1r $W W$, Area 1, Nevada National Security Site, Nye County, Nevada

Figure 25. Graphs showing annual groundwater withdrawals and water levels for well UE-1r WW, Area 1, Nevada National Security Site, Nye County, Nevada, $1984-88$

Figure 26. Diagram showing borehole lithology and well construction for well UE-2ce, Area 2, Nevada National Security Site, Nye County, Nevada

Figure 27. Graphs showing annual groundwater withdrawals and water levels for well UE-2ce, Area 2, Nevada National Security Site, Nye County, Nevada, 1977-2008

Figure 28. Diagram showing borehole lithology and well construction for well UE-5c WW, Area 5, Nevada National Security Site, Nye County, Nevada

Figure 29. Graphs showing annual groundwater withdrawals and water levels for well UE-5c WW, Area 5, Nevada National Security Site, Nye County, Nevada, 1966-2008

Figure 30. Diagrams showing borehole lithology and well construction for wells UE-15d WW (1735-6001 ft) and UE-15d WW (cased), Area 15, Nevada National Security Site, Nye County, Nevada 


\section{Figures-Continued}

Figure 31. Graphs showing annual groundwater withdrawals and water levels for wells UE-15d WW (1735-6001 ft) and UE-15d WW (cased), Area 15, Nevada National Security Site, Nye County, Nevada, 1962-2008

Figure 32. Diagram showing borehole lithology and well construction for well

UE-16d WW, Area 16, Nevada National Security Site, Nye County, Nevada 56

Figure 33. Graphs showing annual groundwater withdrawals and water levels for well UE-16d WW, Area 16, Nevada National Security Site, Nye County, Nevada, 1981-2008

Figure 34. Diagram showing borehole lithology and well construction for well UE-19b 1 WW, Area 19, Nevada National Security Site, Nye County, Nevada ....

Figure 35. Graphs showing annual groundwater withdrawals and water levels for well UE-19b 1 WW, Area 19, Nevada National Security Site, Nye County, Nevada, 1964-66

Figure 36. Diagram showing borehole lithology and well construction for well UE-19C WW, Area 19, Nevada National Security Site, Nye County, Nevada

Figure 37. Graphs showing annual groundwater withdrawals and water levels for well UE-19c WW, Area 19, Nevada National Security Site, Nye County, Nevada, 1974-2008

Figure 38. Diagram showing borehole lithology and well construction for well UE-19e WW, Area 19, Nevada National Security Site, Nye County, Nevada

Figure 39. Graphs showing annual groundwater withdrawals and water levels for well UE-19e WW, Area 19, Nevada National Security Site, Nye County, Nevada, $1964-75$

Figure 40. Diagram showing borehole lithology and well construction for wells UE-19gS (2650-4508 ft) and UE-19gS (2650-7500 ft), Area19, Nevada National Security Site, Nye County, Nevada

Figure 41. Graphs showing annual groundwater withdrawals and water levels for wells UE-19gS (2650-4508 ft) and UE-19gS (2650-7500 ft), Area19, Nevada National Security Site, Nye County, Nevada, 1965-75

Figure 42. Diagram showing borehole lithology and well construction for well UE-20h WW, Area 20, Nevada National Security Site, Nye County, Nevada

Figure 43. Graphs showing annual groundwater withdrawals and water levels for well UE-20h WW, Area 20, Nevada National Security Site, Nye County, Nevada, 1964-66

Figure 44. Diagram showing borehole lithology and well construction for well UE-20j WW, Area 20, Nevada National Security Site, Nye County, Nevada

Figure 45. Graphs showing annual groundwater withdrawals and water levels for well UE-20j WW, Area 20, Nevada National Security Site, Nye County, Nevada, 1964-69

Figure 46. Diagrams showing borehole lithology and well construction for wells UE-25c 3, Ue-25c 3 (2286-2879 ft), and UE-25c 3 (2285-2667 ft), Area 25, Nevada National Security Site, Nye County, Nevada

Figure 47. Graphs showing annual groundwater withdrawals and water levels for wells UE-25c 3, UE-25c 3 (2286-2879), and UE-25c 3 (2285-2667), Area 25, Nevada National Security Site, Nye County, Nevada, 1984-99

Figure 48. Diagram showing borehole lithology and well construction for well $W W-1$, located outside Nevada National Security Site near eastern boundary of Area 5, Nye County, Nevada 


\section{Figures-Continued}

Figure 49. Graphs showing annual groundwater withdrawals and water levels for well WW-1, located outside Nevada National Security Site near eastern boundary of Area 5, Nye County, Nevada, 1950-67

Figure 50. Diagram showing borehole lithology and well construction for well $W W-2$ (3422 ft), Area 2, Nevada National Security Site, Nye County, Nevada 86

Figure 51. Graphs showing annual groundwater withdrawals and water levels for well WW-2 (3422 ft), Area 2, Nevada National Security Site, Nye County, Nevada, 1962-2008

Figure 52. Diagram showing borehole lithology and well construction for well $W W-3$ (1800 ft), Area 6, Nevada National Security Site, Nye County, Nevada

Figure 53. Graphs showing annual groundwater withdrawals and water levels for well WW-3 (1800 ft), Area 6, Nevada National Security Site, Nye County, Nevada, 1952-2008

Figure 54. Diagram showing borehole lithology and well construction for well $W W-4$, Area 6, Nevada National Security Site, Nye County, Nevada

Figure 55. Graphs showing annual groundwater withdrawals and water levels for well WW-4, Area 6, Nevada National Security Site, Nye County, Nevada, 1981-2008 ... 93

Figure 56. Diagram showing borehole lithology and well construction for well $W W-4 A$, Area 6, Nevada National Security Site, Nye County, Nevada 95

Figure 57. Graphs showing annual groundwater withdrawals and water levels for well $W W-4 A$, Area 6, Nevada National Security Site, Nye County, Nevada, 1990-2008

Figure 58. Diagram showing borehole lithology and well construction for well WW-5A, Area 5, Nevada National Security Site, Nye County, Nevada.

Figure 59. Graphs showing annual groundwater withdrawals and water levels for well WW-5A, Area 5, Nevada National Security Site, Nye County, Nevada, 1951-2008

Figure 60. Diagram showing borehole lithology and well construction for well $W W-5 B$, Area 5, Nevada National Security Site, Nye County, Nevada 101

Figure 61. Graphs showing annual groundwater withdrawals and water levels for well WW-5B, Area 5, Nevada National Security Site, Nye County, Nevada, 1951-2008.

Figure 62. Diagram showing borehole lithology and well construction for well $W W-5 C$, Area 5, Nevada National Security Site, Nye County, Nevada 104

Figure 63. Graphs showing annual groundwater withdrawals and water levels for well WW-5C, Area 5, Nevada National Security Site, Nye County, Nevada, 1954-2008

Figure 64. Diagram showing borehole lithology and well construction for wells $W W-8$ (2031-5490 ft) and WW-8 (30-2031 ft), Area 18, Nevada National Security Site, Nye County, Nevada

Figure 65. Graphs showing annual groundwater withdrawals and water levels for wells WW-8 (2031-5490 ft) and WW-8 (30-2031 ft) Area 18, Nevada National Security Site, Nye County, Nevada, 1963-2008

Figure 66. Diagram showing borehole lithology and well construction for well $W W-A$ (1870 ft), Area 3, Nevada National Security Site, Nye County, Nevada

Figure 67. Graphs showing annual groundwater withdrawals and water levels for well $W W-A$, Area 3, Nevada National Security Site, Nye County, Nevada, 1960-2008 


\section{Figures-Continued}

Figure 68. Diagram showing borehole lithology and well construction for wells

$W W-C$ (1373-1701 ft) and WW-C (recompleted), Area 6, Nevada National

Security Site, Nye County, Nevada

Figure 69. Graphs showing annual groundwater withdrawals and water levels for wells

$W W-C$ (1373-1701 ft) and WW-C (recompleted), Area 6, Nevada National

Security Site, Nye County, Nevada, 1961-95

Figure 70. Diagram showing borehole lithology and well construction for well $W W-C-1$, Area 6, Nevada National Security Site, Nye County, Nevada

Figure 71. Graphs showing annual groundwater withdrawals and water levels for well $W W-C-1$, Area 6, Nevada National Security Site, Nye County, Nevada,

1962-2008

\section{Tables}

Table 1. Well characteristics and groundwater withdrawal data for wells on and adjacent to the Nevada National Security Site, Nye County, Nevada

Table 2. Groundwater withdrawal estimates, annual workforce population, and per capita water-use rates for Mercury and Forward areas of Nevada National Security Site, Nye County, Nevada, 1969-85 


\section{Conversion Factors and Datums}

Conversion Factors

\begin{tabular}{lcl}
\hline \multicolumn{1}{c}{ Multiply } & \multicolumn{1}{c}{ By } & \multicolumn{1}{c}{ To obtain } \\
\hline inch (in.) & Length & \\
foot (ft) & 2.54 & centimeter $(\mathrm{cm})$ \\
mile (mi) & 0.3048 & meter $(\mathrm{m})$ \\
& 1.609 & kilometer $(\mathrm{km})$ \\
\hline acre & Area & \\
square mile $\left(\mathrm{mi}^{2}\right)$ & 0.4047 & hectare $(\mathrm{ha})$ \\
\hline & 2.590 & square kilometer $\left(\mathrm{km}^{2}\right)$ \\
\hline gallon (gal) & Volume & \\
million gallons (Mgal) & 0.003785 & cubic meter $\left(\mathrm{m}^{3}\right)$ \\
\hline & 3,785 & cubic meter $\left(\mathrm{m}^{3}\right)$ \\
\hline acre-foot per day (acre-ft/d) & Flow rate & \\
\hline & 0.01427 & cubic meter per second $\left(\mathrm{m}^{3} / \mathrm{s}\right)$ \\
\hline
\end{tabular}

Datums

Vertical coordinate information is referenced to the National Geodetic Vertical Datum of 1929 (NGVD29).

Horizontal coordinate information is referenced to the North American Datum of 1927 (NAD27), unless otherwise stated.

Altitude, as used in this report, refers to distance above the vertical datum. 


\title{
Groundwater Withdrawals and Associated Well Descriptions for the Nevada National Security Site, Nye County, Nevada, 1951-2008
}

\author{
By Peggy E. Elliott and Michael T. Moreo
}

\section{Abstract}

From 1951 to 2008, groundwater withdrawals totaled more than 25,000 million gallons from wells on and directly adjacent to the Nevada National Security Site. Total annual groundwater withdrawals ranged from about 30 million gallons in 1951 to as much as 1,100 million gallons in 1989. Annual withdrawals from individual wells ranged from 0 million gallons to more than 325 million gallons. Monthly withdrawal data for the wells were compiled in a Microsoft ${ }^{\circ}$ Excel 2003 spreadsheet. Groundwater withdrawal data are a compilation of measured and estimated withdrawals obtained from published and unpublished reports, U.S. Geological Survey files, and/or data reported by other agencies. The withdrawal data were collected from 42 wells completed in 33 boreholes. A history of each well is presented in terms of its well construction, borehole lithology, withdrawals, and water levels.

\section{Introduction}

The U.S. Geological Survey (USGS) compiles and maintains groundwater withdrawal data for wells on and adjacent to the Nevada National Security Site (NNSS). Current and historical withdrawal data are reviewed and stored in a Microsoft ${ }^{\complement}$ Excel 2003 spreadsheet (appendix A). Selected withdrawal data for the NNSS previously have been published since 1994 by the USGS in annual water-resources data reports (water years 2002-08 are available at http://wdr. water.usgs.gov/). Annual withdrawal data were compiled for 16 wells from 1951 to 1971 (Claassen, 1973); for 12 wells for 1992 (Robie and others, 1995); for 14 wells for 1993 (Reiner and others, 1995); and for 24 wells from 1951 to 1991 (Wood and Reiner, 1996) with a gap of missing withdrawal data from 1972 to 1982 for most of these 24 wells. Reiner and others (1995) and Robie and others (1995) compiled withdrawal data only for water-supply wells, and excluded any withdrawals from other wells for hydrologic testing or drilling and sampling activities. This report expands on these previously published reports temporally and spatially, includes all wells with known total withdrawals of more than 5 million gallons (Mgal), and includes withdrawals from water-supply wells and wells used for hydrologic testing, drilling, and sampling activities.

Withdrawal data compiled for this report can aid in the management of NNSS water resources, and help with the assessment of the potential effects of withdrawals on groundwater flow. For example, the withdrawal data documented in this report are being used in support of a concurrent study to evaluate temporal changes in water chemistry in selected water-supply wells as a consequence of long-term pumping. Withdrawal data also are used to support efforts to predict the potential for radionuclide transport under pumping and non-pumping conditions.

The study area is in southern Nevada about $65 \mathrm{mi}$ northwest of Las Vegas (fig. 1). The study area is the NNSS and adjacent areas that supply water for NNSS activities. The NNSS, which encompasses about 1,350 $\mathrm{mi}^{2}$, was established in 1950 to support nuclear testing that occurred from 1951 to 1992 (Wills, 2008, p. 1-4). The study area is within the southern Great Basin, an internally draining feature of the Basin and Range physiographic province consisting of north-trending mountain ranges and intervening desert basins (Fenneman, 1931, p. 326). The western and northwestern parts of the study area consist predominantly of Tertiary volcanic rocks to depths of several thousand feet or more. Rocks in the eastern and northeastern parts of the study area consist predominantly of Precambrian metamorphic and siliciclastic rocks, Paleozoic siliciclastic and carbonate rocks, a minor amount of Mesozoic granite, and Cenozoic volcanic rocks and basin fill. Basin fill occurs in low-lying tectonic basins, such as Yucca and Frenchman Flats (fig. 1), and consists primarily of Pleistocene to Holocene alluvial deposits, Pliocene to Holocene colluvium, and Holocene playa deposits (Slate and others, 1999). Carbonate rocks, ash-flow tuffs and lavas, and alluvium are the primary aquifers supplying water to wells in the study area (Fenelon and others, 2010). 


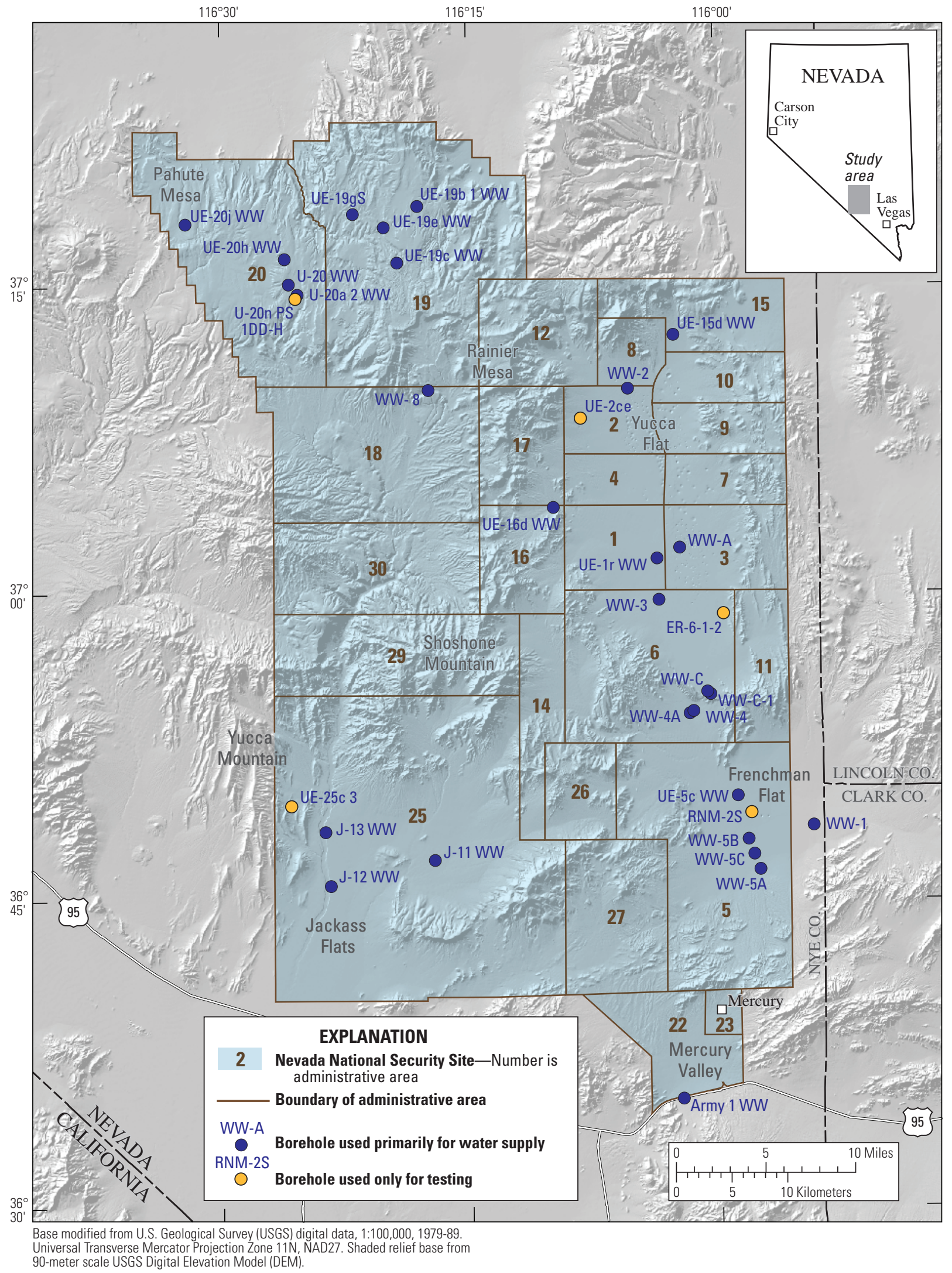

Figure 1. Boreholes used for water withdrawal in support of Nevada National Security Site activities, Nye County, Nevada. 
The climate of the study area, as described by Houghton and others (1975) and Soule' (2006), is a semi-arid high desert with cold winters and hot summers. Annual precipitation averages about 13 in. at high altitudes but less than 5 in. in the basins. Precipitation occurs mostly in the winter to early spring and summer. Pacific storms typically produce snowfall in high altitudes and rain in the basins during the winter, and thunderstorms occur throughout the study area during the summer.

\section{Purpose and Scope}

This report documents monthly groundwater withdrawal data from 1951 to 2008 for wells on and directly adjacent to the NNSS (fig. 1). Withdrawal data were collected from 42 wells completed in 33 boreholes (table 1). This report expands upon previously published datasets, and provides a temporally and spatially comprehensive compilation of measured and estimated withdrawal data for the NNSS. Withdrawal data compiled for this report are presented in appendix A.

Descriptions of the 42 withdrawal wells in this report are presented by borehole. The descriptions provide a history of each well and include well-construction and boreholelithology diagrams, and graphs of annual groundwater withdrawals and measured water levels. A photograph also is provided for most of the borehole sites. A Microsoft ${ }^{\odot}$ Excel 2003 spreadsheet (appendix A) provides monthly groundwater withdrawal data in an interactive format that allows the user to select a well name and view the withdrawal data and a generalized well-construction and borehole lithology diagram, and a site map showing borehole locations.

\section{Methods and Data Sources}

Groundwater withdrawal data for the NNSS were obtained from published and unpublished reports, USGS files, and/or data reported by other agencies. Estimates based on established water-use patterns were used when withdrawal records were unavailable. All measured and estimated withdrawal data were compiled, reviewed, and stored in a Microsoft ${ }^{\odot}$ Excel spreadsheet.

Measured groundwater withdrawal data were compiled mostly from water-production reports from successive U.S. Department of Energy (DOE) contractors: Reynolds Electrical \& Engineering Co., Inc. (REECo), Bechtel Nevada, and National Security Technologies, LLC (NSTec). Paper records of the water-production reports are filed at the USGS office in Henderson, Nevada. Withdrawal data from the water-production reports are referred to as metered data in the "Data" sheet of the Microsoft ${ }^{\circledR}$ Excel spreadsheet in appendix A. The water-production reports include cumulative in-line flow-meter readings made during periodic visits to the wells since the late 1950s. In-line flow meters record the cumulative amount of water pumped from a well by measuring the flow rate of water through a pump discharge pipe. For quality assurance, the flow rates recorded by the in-line flow meters at 7-10 wells have been checked annually by the USGS since 1998. Paper records documenting the comparison of flow-meter measurements also are filed at the USGS office in Henderson, Nevada. This comparison was made using a portable acoustic-velocity (ultrasonic transit-time) flow meter clamped onto the outside of the same pump discharge pipe as the in-line flow meter. An average of three instantaneous measurements of flow from the in-line flow meter and the acoustic-velocity flow meter generally were used for comparison. Differences between the two independent measurement methods ranged from 0 to 26 percent, but generally were less than or equal to 10 percent about 85 percent of the time.

Other sources of measured withdrawal data were provided by the following:

- Lawrence Livermore National Laboratory (Mavrik Zavarin, written commun., 2007) compiled cumulative withdrawal data for well UE-2ce from 1977 to 1984 as part of a radionuclide migration study (Buddemeier and Isherwood, 1985, p. 18);

- Los Alamos National Laboratory (J.L. Thompson, written commun., 1992) collected cumulative withdrawal data at well RNM-2S from 1975 to 1991 as part of the Cambric migration experiment (Bryant, 1992);

- USGS collected cumulative withdrawal data from multiple well completion intervals during various production tests at borehole UE-25c 3 in 1984, 1995, and 1996-97 (Geldon, 1996; Geldon and others, 1998, 2002; and A.L. Geldon, U.S. Geological Survey, written commun., 1999); and

- Stoller-Navarro Joint Venture (written commun., 2005) collected cumulative withdrawal data from well ER6-1-2 main during a multiple well aquifer test at the ER-6-1 well cluster from April to July 2004 (StollerNavarro Joint Venture, 2005).

For this report, the term "production test" is used to represent any type of short-term (hours to days) or long-term (months to years) test where water was pumped from the well and includes aquifer, capacity, hydraulic, hydrologic, performance, pump, and tracer tests, unless otherwise noted. 


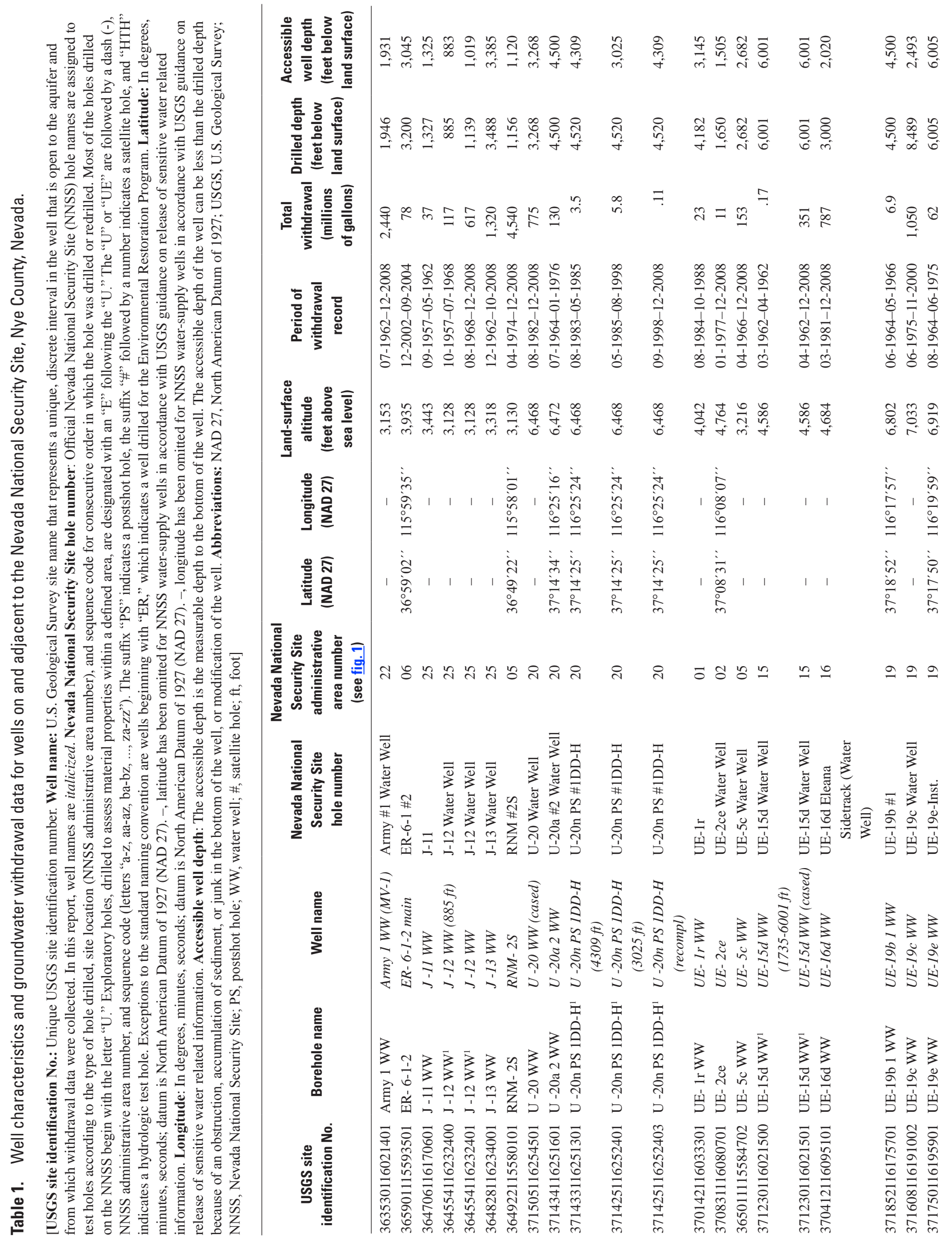




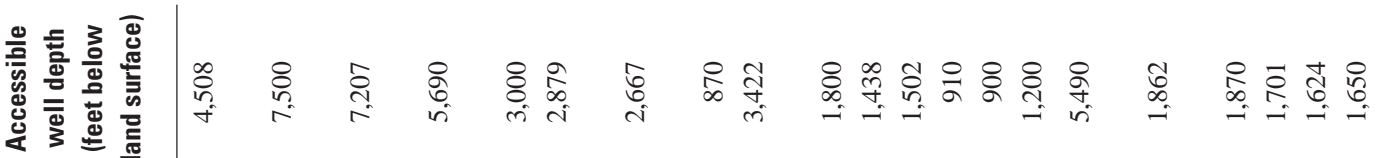

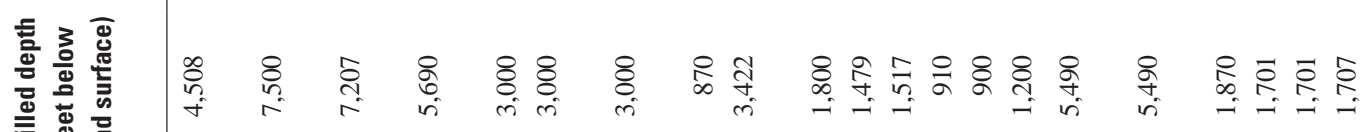
言冚

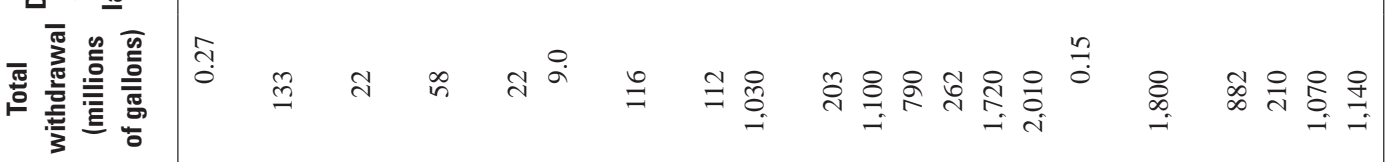

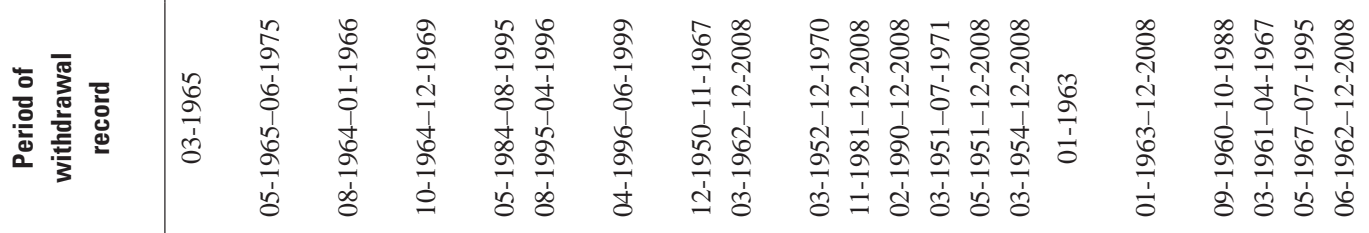

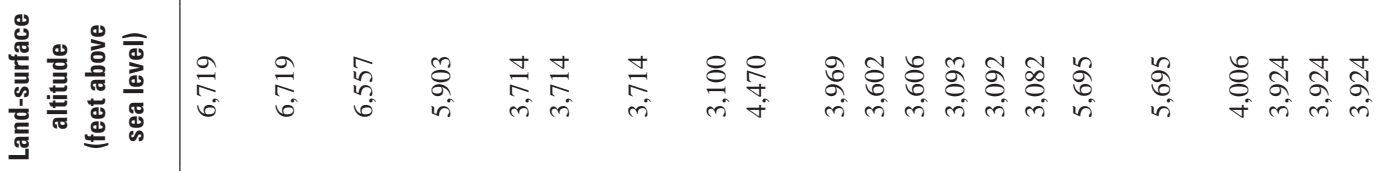

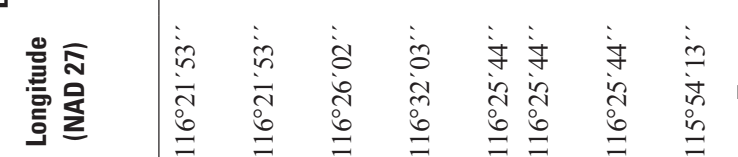

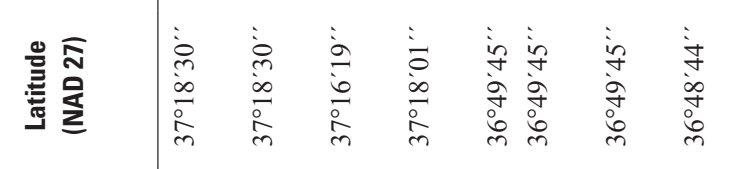

ᄀ ิ จำน

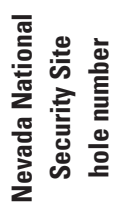

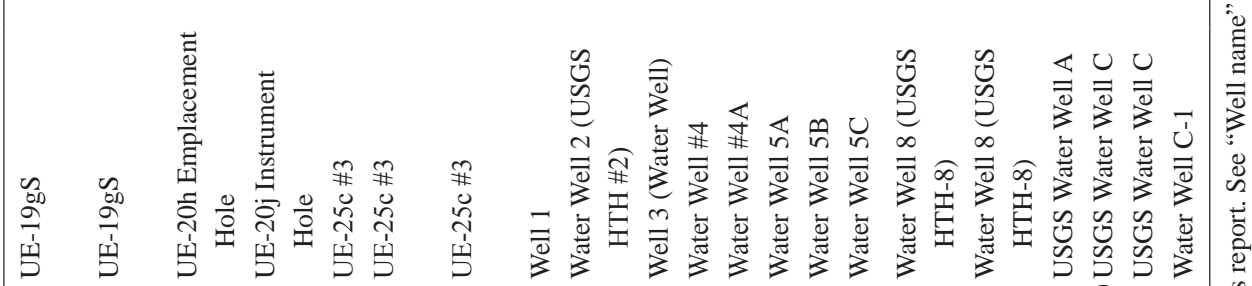

3

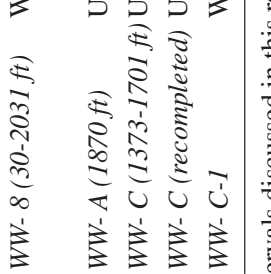

$\frac{8}{8}$

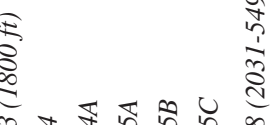

$\sum^{-1}$

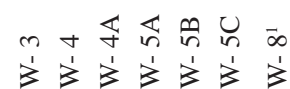

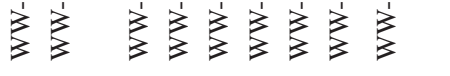


Groundwater withdrawals for periods when metered withdrawal data were unavailable were estimated using various methods. Claassen (1973) compiled annual withdrawal data for 16 water-supply wells from 1951 to 1971 . For wells with missing metered withdrawal data during this period, the gap was estimated using the "annual production” value reported in Claassen (1973). If metered data for an entire year were unavailable, then the estimated gap is the "annual production” value reported in Claassen (1973) for that year. If metered data were available for part of a year, then the estimated withdrawals for the remainder of the year were calculated by subtracting the available metered data for that year from the "annual production" value reported in Claassen (1973). Small gaps (1 month or less) in metered withdrawal data were estimated based on metered data bracketing the gap, if data from Claassen (1973) were not available. When less than one-half of a month of withdrawal data were unavailable, data were estimated based on the daily average of the metered data for that month. If more than one-half of a month of withdrawal data were unavailable, data were estimated based on the daily or monthly average of metered data reported for the month(s) preceding and following the data gap; the monthly average was used if the month(s) preceding and following the data gap were complete, otherwise the daily average was used. In some cases, estimates were based on pump run times recorded on daily ammeter charts or were provided by other agencies. For all estimated withdrawal data, the method of estimation, period estimated, and amount estimated are listed for each record in the "Data" sheet of the Microsoft ${ }^{\circledR}$ Excel spreadsheet in appendix A.

Metered groundwater withdrawals were not available for water-supply wells on the NNSS between 1972 and 1982. Groundwater withdrawals from water-supply wells believed to be active during this period were estimated using NNSS workforce population and per capita water-use rates (table 2). A similar estimate was made by Moreo and others (2003), but for this report, withdrawals were estimated separately for Mercury (NNSS administrative areas 22 and 23) and for the forward areas north of Mercury (all NNSS administrative areas except areas 22, 23, and 25; fig. 1; table 2).

Table 2. Groundwater withdrawal estimates, annual workforce population, and per capita water-use rates for Mercury and Forward areas of Nevada National Security Site, Nye County, Nevada, 1969-85.

[Groundwater withdrawals in shaded area of table were estimated from population data and per capita water-use rates. Annual workforce population: Data from U.S. Department of Energy, National Nuclear Security Administration, Nevada Site Office (written commun., 2009). NNSS, Nevada National Security Site]

\begin{tabular}{|c|c|c|c|c|c|c|}
\hline \multirow[b]{2}{*}{ Year } & \multicolumn{3}{|c|}{ Mercury (NNSS administrative areas 22 and 23) } & \multicolumn{3}{|c|}{$\begin{array}{l}\text { Forward areas (NNSS administrative areas } \\
\text { north of Mercury, excludng areas } 22,23,25 \text { ) }\end{array}$} \\
\hline & $\begin{array}{c}\text { Annual workforce } \\
\text { population }\end{array}$ & $\begin{array}{c}\text { Per capita } \\
\text { water-use rate } \\
{[(\text { gallons/person)/day)] }}\end{array}$ & $\begin{array}{c}\text { Annual } \\
\text { groundwater } \\
\text { withdrawals } \\
\text { (million } \\
\text { gallons) }\end{array}$ & $\begin{array}{c}\text { Annual workforce } \\
\text { population }\end{array}$ & $\begin{array}{c}\text { Per capita } \\
\text { water-use rate } \\
\text { [(gallons/person)/day] }\end{array}$ & $\begin{array}{c}\text { Annual } \\
\text { groundwater } \\
\text { withdrawals } \\
\text { (million } \\
\text { gallons) }\end{array}$ \\
\hline 1969 & 1,702 & 126 & 78 & 4,147 & 263 & 398 \\
\hline 1970 & 1,436 & 132 & 69 & 3,236 & 268 & 316 \\
\hline 1971 & 1,303 & 202 & 96 & 3,239 & 247 & 292 \\
\hline $1972^{1}$ & 1,109 & 122 & 49 & 2,863 & 296 & 310 \\
\hline 1973 & 1,262 & 122 & 56 & 2,420 & 297 & 262 \\
\hline 1974 & 1,260 & 122 & 56 & 2,571 & 297 & 279 \\
\hline 1975 & 1,251 & 122 & 56 & 2,611 & 297 & 283 \\
\hline $1976^{1}$ & 1,311 & 122 & 58 & 2,286 & 296 & 248 \\
\hline 1977 & 1,250 & 122 & 56 & 2,107 & 297 & 228 \\
\hline 1978 & 1,242 & 122 & 55 & 2,273 & 297 & 246 \\
\hline 1979 & 1,266 & 122 & 56 & 2,022 & 297 & 219 \\
\hline $1980^{1}$ & 1,299 & 122 & 58 & 2,247 & 296 & 244 \\
\hline 1981 & 1,449 & 122 & 64 & 2,592 & 297 & 281 \\
\hline 1982 & 1,489 & 122 & 66 & 3,015 & 297 & 327 \\
\hline 1983 & 1,827 & 85 & 57 & 2,755 & 332 & 334 \\
\hline 1984 & 1,662 & 137 & 83 & 3,089 & 348 & 394 \\
\hline 1985 & 1,627 & 70 & 41 & 3,369 & 338 & 416 \\
\hline
\end{tabular}

${ }^{1}$ Estimated per capita water-use rate adjusted for leap years 
Groundwater withdrawals from well Army $1 \mathrm{WW}$ ( $M V$-1) were assumed to support the workforce population reported for Mercury. A per capita water-use rate of 122 (gallons/person)/day was calculated for Mercury using 6 years of metered data for 1969-71 and 1983-85. This per capita rate was calculated by dividing the sum of annual withdrawals from well Army 1 WW (MV-1) by the sum of workforce population for Mercury for the 6-year period, and then dividing by the number of days in a year (table 2). Groundwater withdrawals during the gap period 1972-82 are then estimated by multiplying the calculated annual per capita water-use rate by the workforce population for each year of the gap (table 2).

Withdrawals from wells north of Mercury (UE-5c WW, $U E-15 d W W$ (cased), UE-16d WW, UE-19c WW, WW-2 (3422 ft), WW-5B, WW-5C, WW-8 (30-2031 ft), WW-A (1870 ft), WW-C (recompleted), and $W W-C-1$ ) were assumed to support the workforce population reported for the forward areas. Similar to the approach for estimating groundwater withdrawals for Mercury, a per capita water-use rate of 297 (gallons/person)/day was calculated for the forward areas using 6 years of metered data for 1969-71 and 1983-85. Using this estimated per capita rate, annual groundwater withdrawals from all forward area wells were estimated for the gap period 1972-82 (table 2). This estimated annual withdrawal amount was then apportioned to each forward area well according to the percentage of withdrawals contributed by each well during the pre- and post-gap period. For example, withdrawals from well WW-8 (30-2031 ft) accounted for about 16 percent of total forward area withdrawals during the pre- and post-gap period; therefore, 16 percent of the estimated total withdrawal during the gap period is attributed to well $W W-8$ (30-2031 ft). Groundwater withdrawals from forward area wells decreased from $398 \mathrm{Mgal}$ in 1969 to an estimated $219 \mathrm{Mgal}$ in 1979, and then increased to $416 \mathrm{Mgal}$ in 1985 following corresponding changes in population. The correlation between population and withdrawals for the forward areas allows for a reasonable annual groundwater withdrawal estimate for the forward areas as a whole. However, apportioning a percentage of the estimated total withdrawal to each well may result in large uncertainties. Because quantifying uncertainty for individual wells is difficult, estimates for 1972-82 (appendix A) should be used with caution.

Withdrawal data in this report were collected from 33 boreholes. In some boreholes, water was withdrawn from more than one well completion interval. A well completion interval represents a discrete interval in the borehole that is open to the aquifer and from which withdrawal data were collected. Unique completions in a single borehole result from the installation or removal of casing or perforated casing, the temporary installation of packers, or the deepening of a borehole after water was produced from a shallower interval. To distinguish multiple completions in a borehole, a parenthetical expression is assigned to the borehole name. For example, two completion intervals are included in this report for borehole WW-8-well WW-8 (2031-5490 ft) and well $W W-8(30-2031 \mathrm{ft})$. Well names are shown in italics. In this example, the numbers in parentheses indicate the depths of the open intervals for the well completion intervals.

In this report, withdrawal data from the 33 boreholes are presented by well completion interval; 42 wells representing unique completion intervals are listed in table 1 and appendix A. The wells are assigned a unique USGS site identification number and site name. Withdrawal data and well characteristics are provided separately for each well (table 1; appendix A). Only wells used for water withdrawals are included in this report.

Monthly withdrawal data are stored in a Microsoft $\left.{ }^{(}\right)$ Excel spreadsheet in the "Data" sheet in appendix A. The "View data" sheet in the spreadsheet contains an interactive format that allows the user to select a specific well name and view associated withdrawal data and a generalized well-construction and borehole-lithology diagram, and a site map showing borehole locations. A sample page from the spreadsheet is shown in figure 2. Data are selected from the pull-down menu labeled "Well name"; data for well Army $1 W W(M V-1)$ are shown. For each well, general well characteristics are displayed including USGS site identification number, latitude, longitude, hydrographic and NNSS areas, date well construction completed, primary aquifer, land-surface altitude, hole and well depths, bottom of casing, top and bottom open intervals, and casing diameter. A table that displays either monthly or annual withdrawal data for the selected well is below the well characteristics. Monthly or annual withdrawal data are selected using the pull-down menu at the top of the withdrawal data table. Withdrawal data are displayed graphically at the top of the page above the "Well name" pull-down menu. A generalized well-construction and borehole-lithology diagram is displayed to the right of the withdrawal data graph. This diagram is a general representation of casing and screened or open intervals for the selected well and lithology of the borehole. The casing, open intervals, and lithology are defined by color in the "Explanation" table below the diagram. At the far right of the "View data" sheet in the Microsoft ${ }^{\complement}$ Excel spreadsheet in appendix A, a map of the study area displays the locations of the boreholes. 


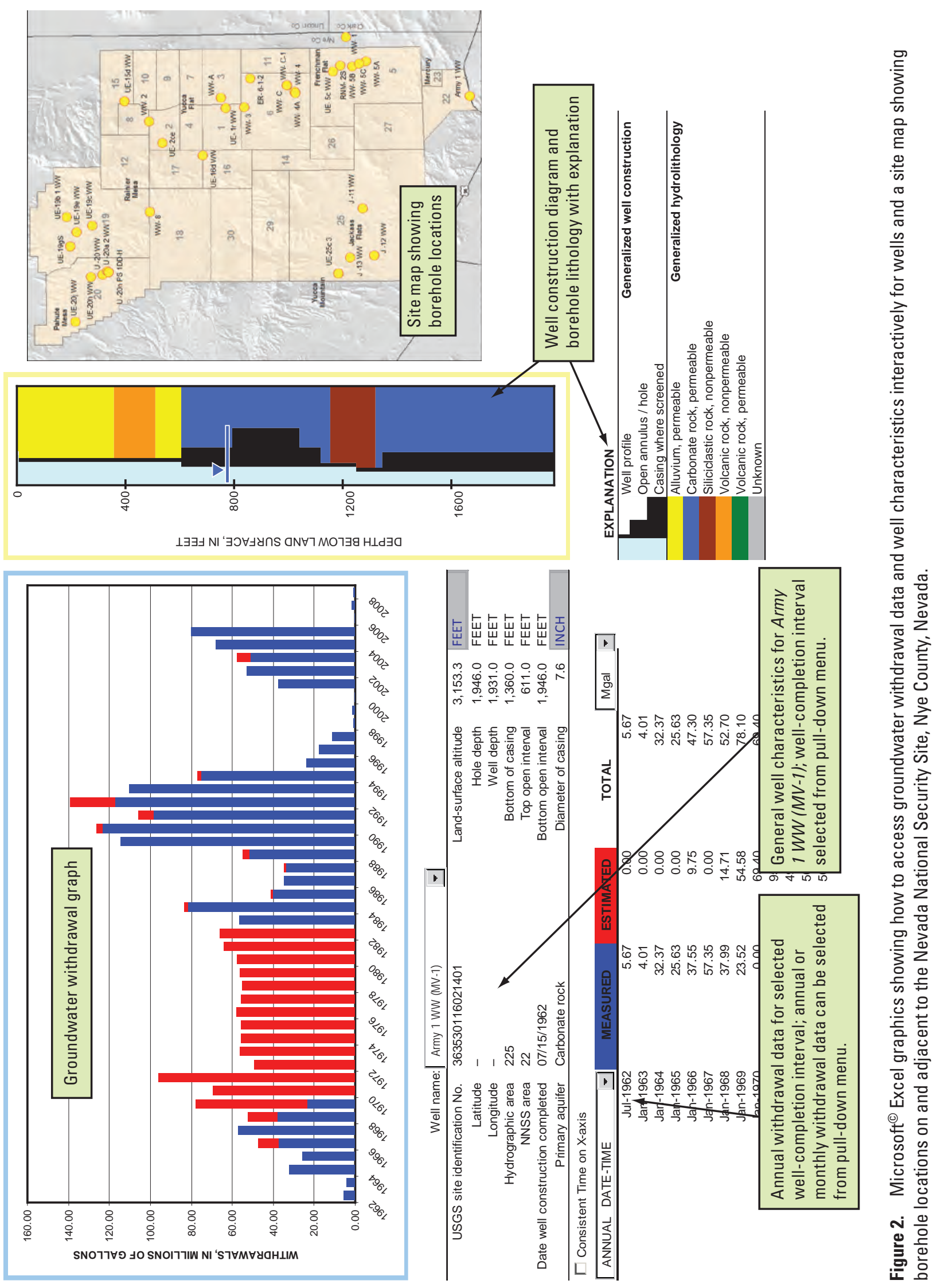


Groundwater Withdrawals for the Nevada National Security Site

Development of groundwater on the NNSS began in 1951. Through 2008, more than 25,000 Mgal of water have been withdrawn from 42 wells completed in 33 boreholes on and directly adjacent to the NNSS (fig. 3). Since 1951, water pumped from the wells has been used to support NNSS programs, projects, and personnel; the wells provide water for

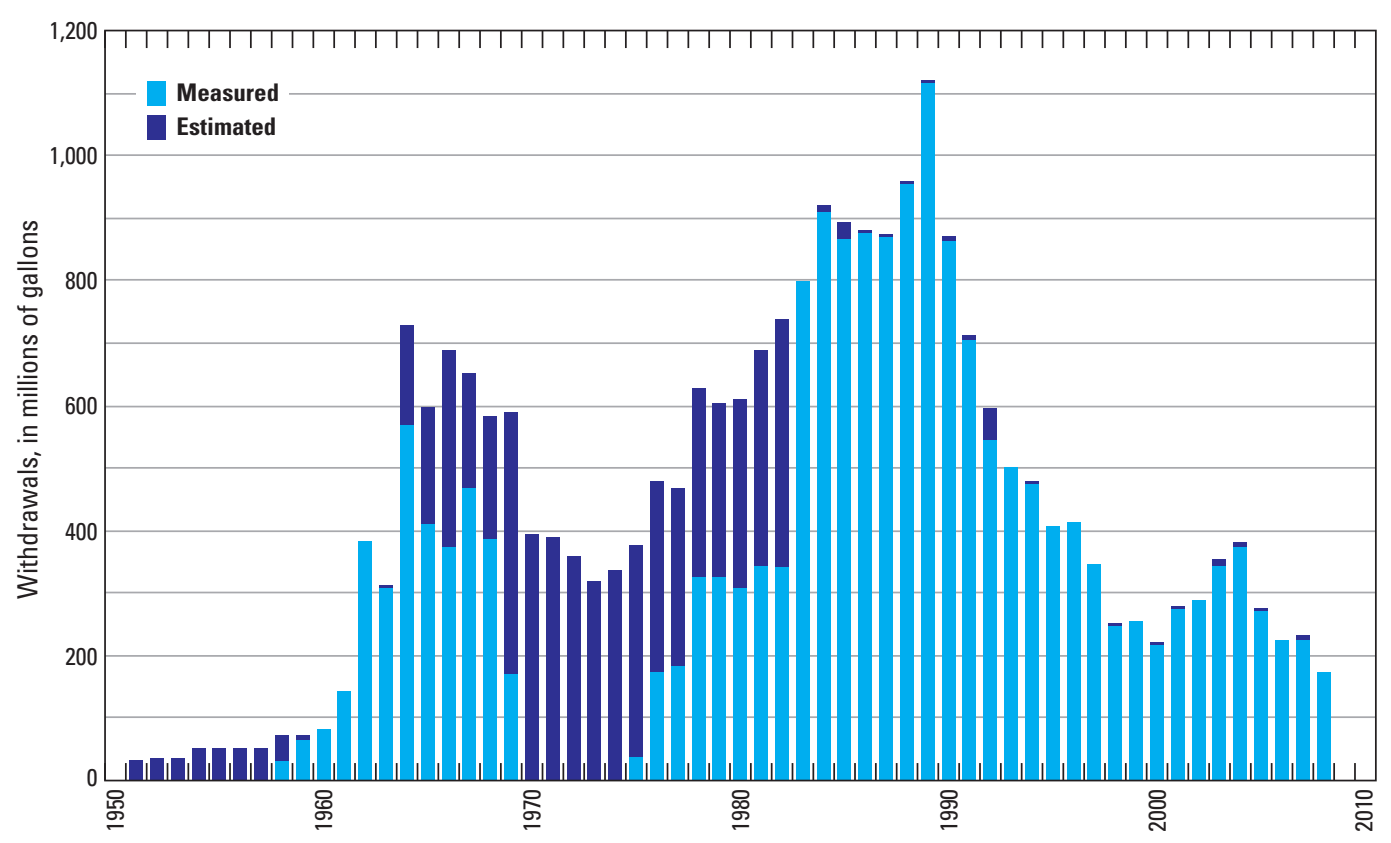

Figure 3. Graph showing annual groundwater withdrawals for the Nevada National Security Site, Nye County, Nevada, 1951-2008. various NNSS activities including construction, drilling, fire protection, aquifer testing, nuclear testing, and dust control (U.S. Department of Energy, 2008, p. 2-1, 2-6). More than 90 percent of total withdrawals were from 16 of the 42 wells; withdrawals from 11 of these 16 wells were more than 1,000 Mgal through 2008 (table 1). Total annual groundwater withdrawals for the NNSS ranged from about $30 \mathrm{Mgal}$ in 1951 to 1,100 Mgal in 1989. Annual groundwater withdrawals from individual wells ranged from 0 Mgal at many wells to more than $325 \mathrm{Mgal}$ at well RNM-2S in 1979.

Changes in groundwater withdrawals in the study area correspond with changes in NNSS-related activities. For example, increases in groundwater withdrawals likely are related to the development and maintenance of the Nuclear Rocket Development Station in Jackass Flats (Young, 1972, p. 17) and increased nuclear testing (U.S. Department of Energy, 2000, p. xi) in the 1960s, and radionuclide migration studies in the mid- to late-1970s to 1980s (fig. 3) (Buddemeier and Isherwood, 1985; Bryant, 1992; Sawyer and others, 1999). Decreases in groundwater withdrawals occurred as these activities decreased or were completed, and after a nuclear testing moratorium in the early 1990s (U.S. Department of Energy, 2000, p. viii).

Groundwater was withdrawn from four major regions on the NNSS where nuclear testing occurred: Frenchman Flat, Yucca Flat, Pahute Mesa, and Rainier Mesa (fig. 1; U.S. Department of Energy, 2000, p. xviii). About 8,800 Mgal of water were withdrawn from six boreholes in Frenchman Flat (Area 5 and one offsite hole) from 1951 to 2008; about 6,900 Mgal of water were withdrawn from 11 boreholes in the Yucca Flat region (Areas 1-3, 6, 15) from 1952 to 2008; more than 2,200 Mgal of water were withdrawn from nine boreholes on

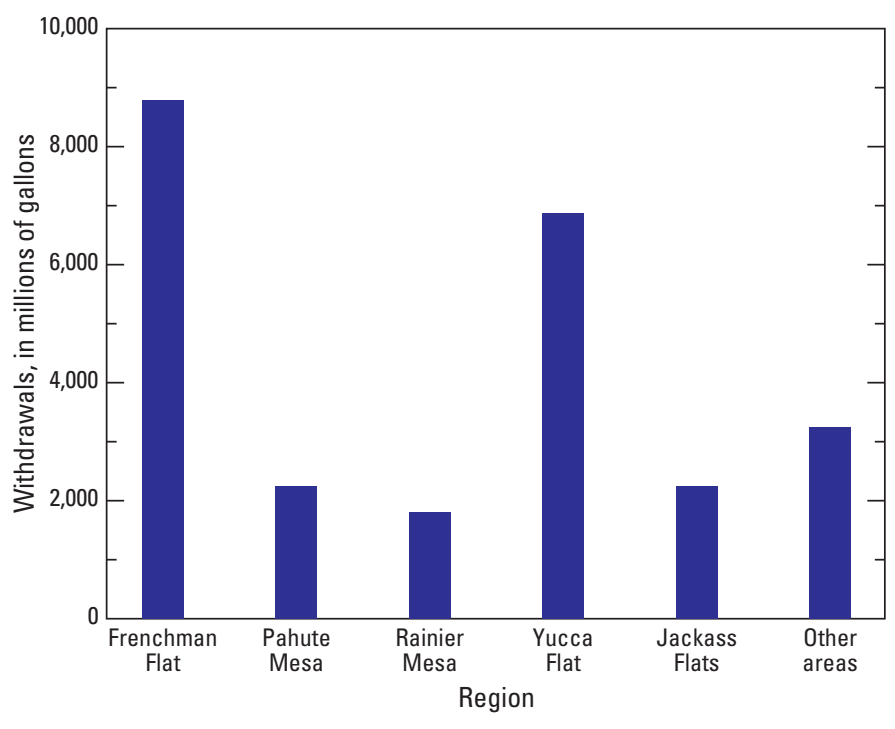

Figure 4. Groundwater withdrawals by region on the Nevada National Security Site, Nye County, Nevada, 1951-2008.

Pahute Mesa (Areas 19 and 20) from 1964 to 2008; and about $1,800 \mathrm{Mgal}$ of water were withdrawn from one borehole in Area 18, for activities in the Rainier Mesa region, from 1963 to 2008 (fig. 4).

Groundwater also was withdrawn from areas outside of the four nuclear testing regions. More than 2,200 Mgal of water were withdrawn from four boreholes in the Jackass Flats area (Area 25) from 1957 to 2008; and more than 3,200 Mgal of water were withdrawn from the two remaining boreholes, in Areas 16 and 22, from 1962 to 2008 (figs. 1 and 4). 


\section{Well Descriptions}

Descriptions of the 42 withdrawal wells are presented by borehole. The descriptions provide a history of each well completion interval, and include a well-construction and borehole-lithology diagram, and graphs of annual groundwater withdrawals and measured water levels for each well. A photograph also is provided for most of the borehole sites. Many of the withdrawal wells also serve as observation or monitoring wells for periodic water-level and/or temperature measurements and sampling. Water levels measured in the wells are stored in the U.S. Geological Survey's National Water Information System (NWIS) and can be accessed on the World Wide Web at http://waterdata.usgs.gov/nv/nwis. Hydrographs are presented with the well descriptions. The hydrographs generally represent pre-pumping water levels or water levels that were measured at least 24 hours after a well was pumped. Water-level measurements that represent short-term changes from pumping, construction, or other activities in the well have been excluded, unless otherwise noted. Water-temperature data for select wells can be accessed through the USGS/DOE Cooperative Studies in Nevada web page (http://nevada.usgs.gov/doe nv/). Water-supply wells also have been sampled periodically from 1972 to 1998 as part of DOE's Long-Term Hydrological Monitoring Program
(LTHMP) and from 1999 to present as part of Routine Radiological Environmental Monitoring Plan (RREMP; Bechtel Nevada, 2003). As part of this monitoring, the wells are sampled by a DOE contractor to determine if radionuclides from underground nuclear testing have contaminated the groundwater in the vicinity of the test sites. Frequency of sampling is dependent on analytes monitored and ranges from 3 months to 3 years (U.S. Department of Energy, 2008, table A-1). Wells completed in the following boreholes are or have been part of this monitoring network: Army $1 \mathrm{WW}$; J-12 WW; J-13 WW; U-20 WW; U-20a 2 WW; UE-5c WW; UE-15d WW; UE-16d WW; UE-19c WW; UE-19gS; WW-2; WW-4; WW-4A; WW-5B; WW-5C; WW-8; WW-A; WW-C; and $\mathrm{WW}-\mathrm{C}-1$.

Most of the data used to construct the borehole lithology diagrams included in each well description were obtained from and are available in databases by Warren and others (2003) and Wood (2007) (see well diagrams in this report for additional lithologic sources). The lithology descriptions on the diagrams have been categorized into lithologic units modified after Warren and others (2003) lithology list. The lithologic units were assigned a specific lithologic pattern and are shown in figure 5. Similar units were assigned the same pattern. 

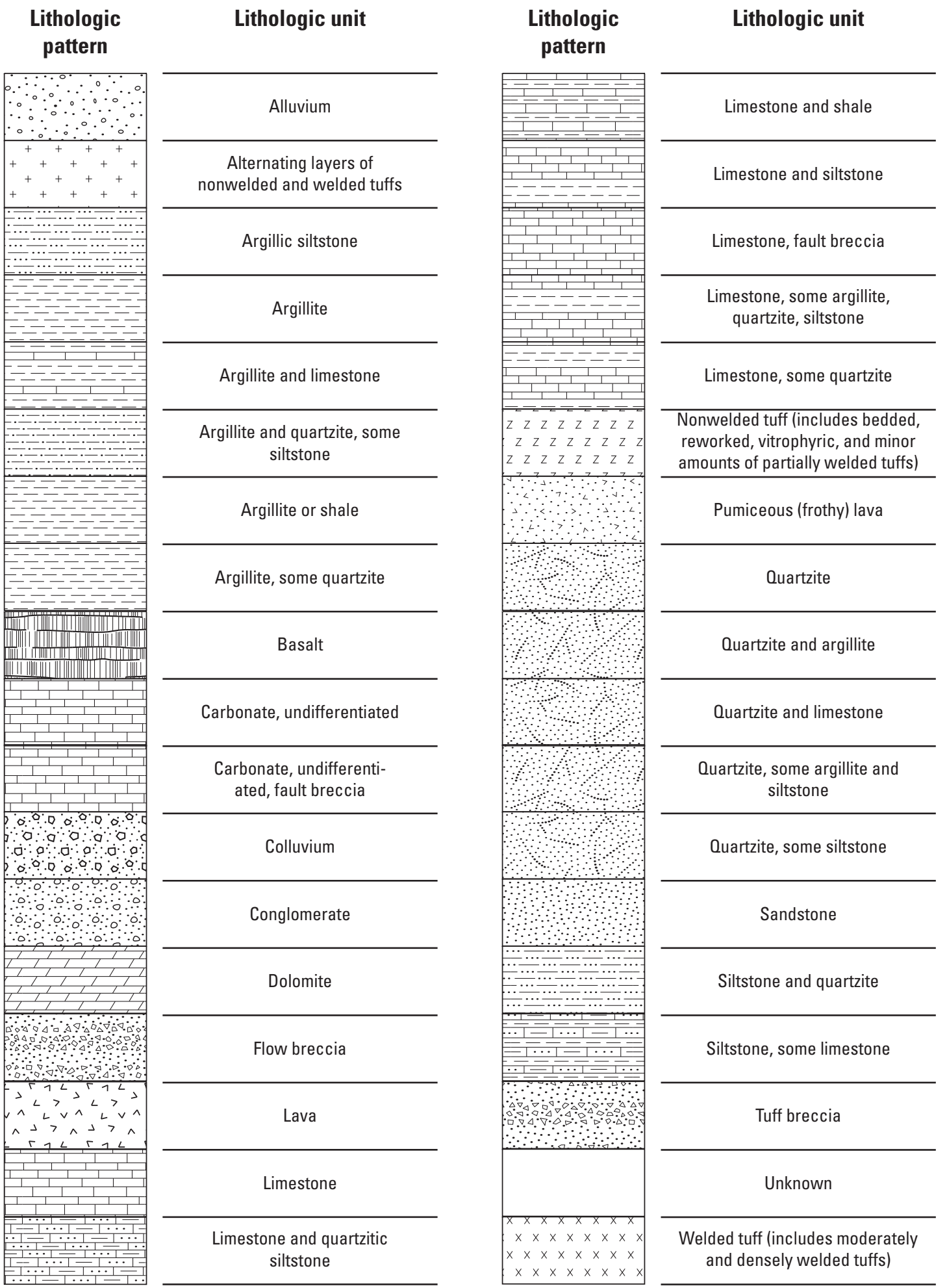

Figure 5. Lithologic patterns and units used in the lithology diagrams for wells on and adjacent to the Nevada National Security Site, Nye County, Nevada. 
Army 1 WW.-Army 1 WW is in Area 22 on the NNSS, about $5 \mathrm{mi}$ southwest of Mercury, Nevada (ifg. 1; table 1; Army 1 WW photograph). Construction information for the borehole was compiled from Moore (1962) and G.L. Meyer and R.E. Smith (U.S. Geological Survey, written commun., 1964). The borehole was drilled and completed to a depth of $620 \mathrm{ft}$ below land surface in July 1958 using the cable-tool method (Moore, 1962, p. 21). Drilling was stopped after encountering dolomite, which was believed at the time not to contain or release significant quantities of groundwater (Moore, 1962, p. 21). In July 1962, the borehole was deepened to $1,946 \mathrm{ft}$ using a combination air-hydraulic rotary drilling machine (G.L. Meyer and R.E. Smith, U.S. Geological Survey, written commun., 1964, p. 1). Borehole diameter ranges from 26 in. at land surface to 6.12 in. at the bottom of the hole.

Borehole Army $1 \mathrm{WW}$ has a single completion interval, well Army 1 WW (MV-1), which includes casing to a depth of 1,360 ft, and an open borehole to 1,946 ft (ig. 6). The casing is perforated from 800 to $1,050 \mathrm{ft}$ and the annular space between the casing and borehole is open above and below this interval. The lithology at the saturated part of the open interval consists of Paleozoic carbonate rocks (fig. 6; Wood, 2007). The well is open to two water-producing zones within the carbonate rocks (G.L. Meyer and R.E. Smith, U.S. Geological Survey, written commun., 1964, p. 3). The upper zone extends from 786 to about 1,050 ft below land surface, and the lower zone extends from 1,360 to 1,946 ft below land surface.

Army 1 WW originally was drilled to be used for water supply at a nearby Army post in Mercury Valley (Moore, 1962, p. 21), but was never used for this purpose (G.L. Meyer and R.E. Smith, U.S. Geological Survey, written commun., 1964, p. 1). Upon completion, well Army 1 WW (MV-1) was used for water supply on the NNSS from 1962 to 2005. The well also has been part of DOE's hydrologic monitoring network since 1972 (Russell, 1989; Bechtel Nevada, 2003; U.S. Department of Energy, 2008, p. 7-6). Use of the well for water supply was discontinued in September 2005 because of elevated arsenic concentrations (Wills, 2006, p. 4-24). Since 2005, however, the well continues to be pumped for short periods of time to maintain the pump (W.R. Templeton, National Security Technologies, LLC, written commun., 2008) and for quarterly sampling (T.J. Redding, National Security Technologies, LLC, written commun., 2010). More than 2,400 Mgal of water have been withdrawn from the well through 2008 (ig. 7A; appendix A).

Periodic water-level measurements made in well Army $1 \mathrm{WW}(\mathrm{MV}$-1) since 1962 are shown in figure $7 \mathrm{~B}$. The water levels range from about 784-792 ft below land surface. Measurements from 1963 to 2005 show the effects of pumping in the well. Maximum drawdown in the aquifer, as measured in the well, is about $8 \mathrm{ft}$.

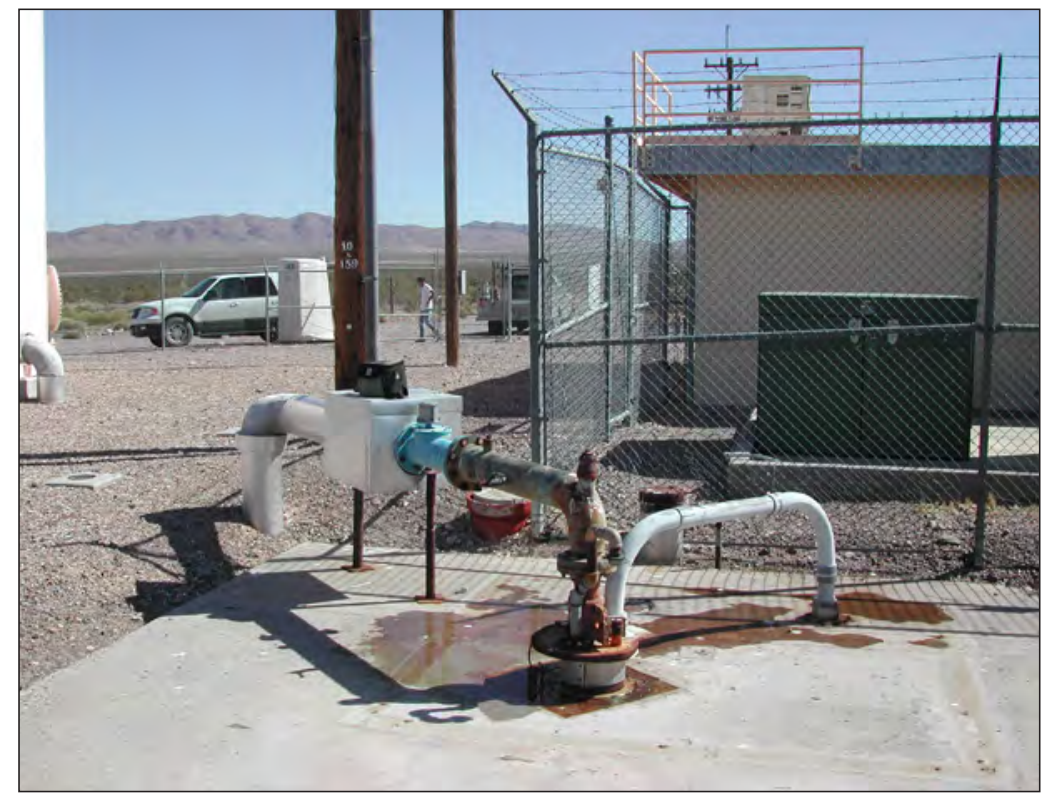

Army 1 WW, July 2005. Photograph by Richard J. La Camera, U.S. Geological Survey. 
Well name: Army 1 WW (MV-1)

USGS site identification No.: 363530116021401

Land-surface altitude: 3,153 feet above National Geodetic Vertical Datum of 1929 (NGVD29)

Latitude: -

Longitude:-

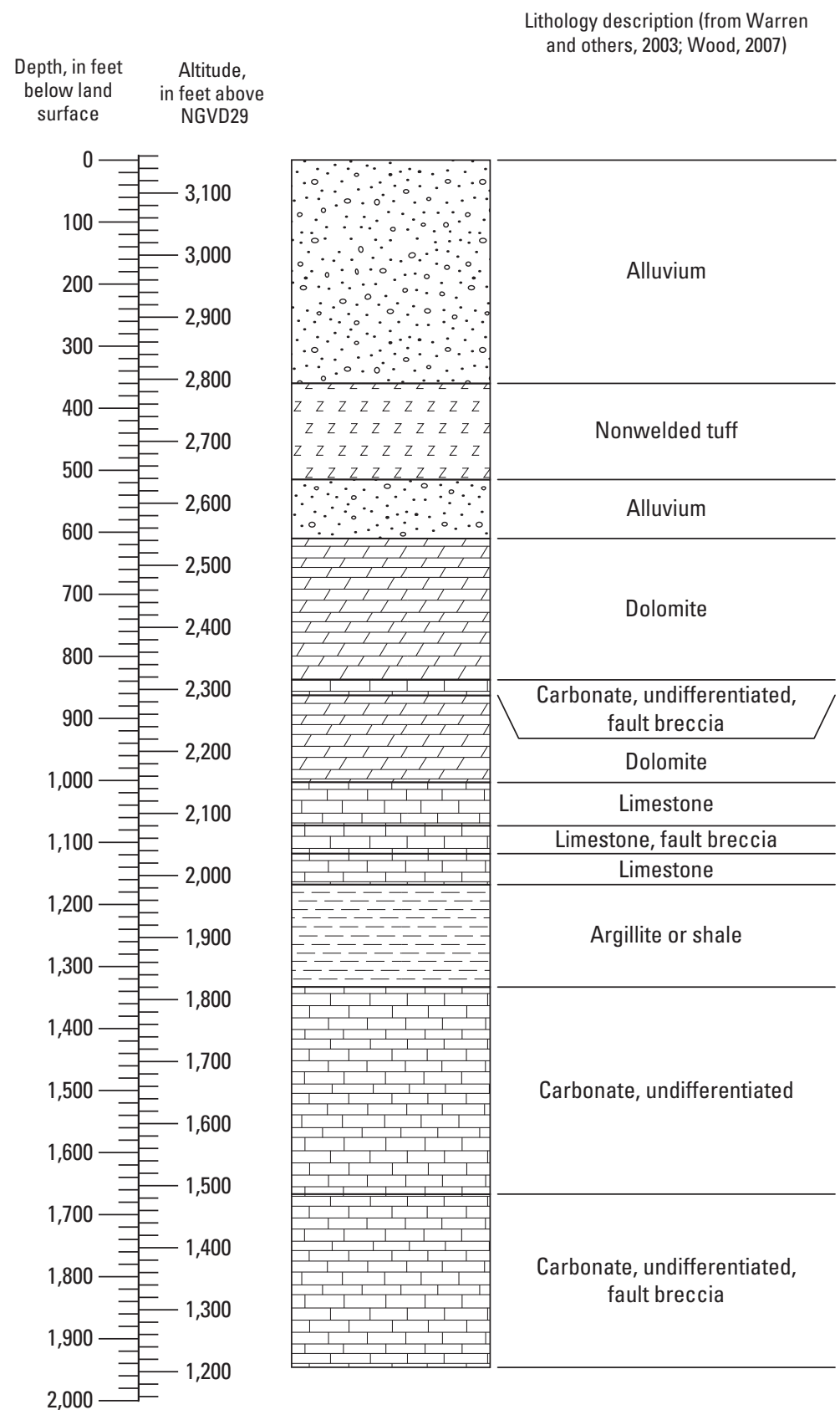

Well-construction diagram (from G.L. Meyer and R.E. Smith, U.S. Geologica Survey, written commun., 1964)
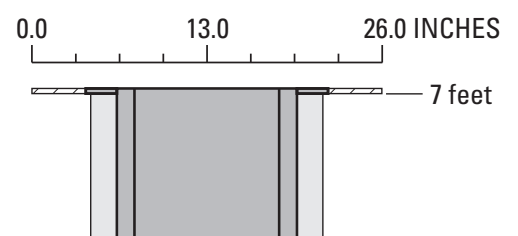

\section{EXPLANATION}

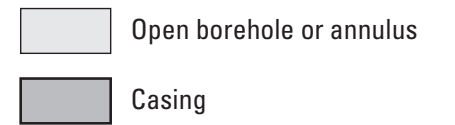

Cement exact thickness unknown

$\nabla \quad$ Average water level

Figure 6. Borehole lithology and well construction for well Army 1 WW (MV-1), Area 22, Nevada National Security Site, Nye County, Nevada. 

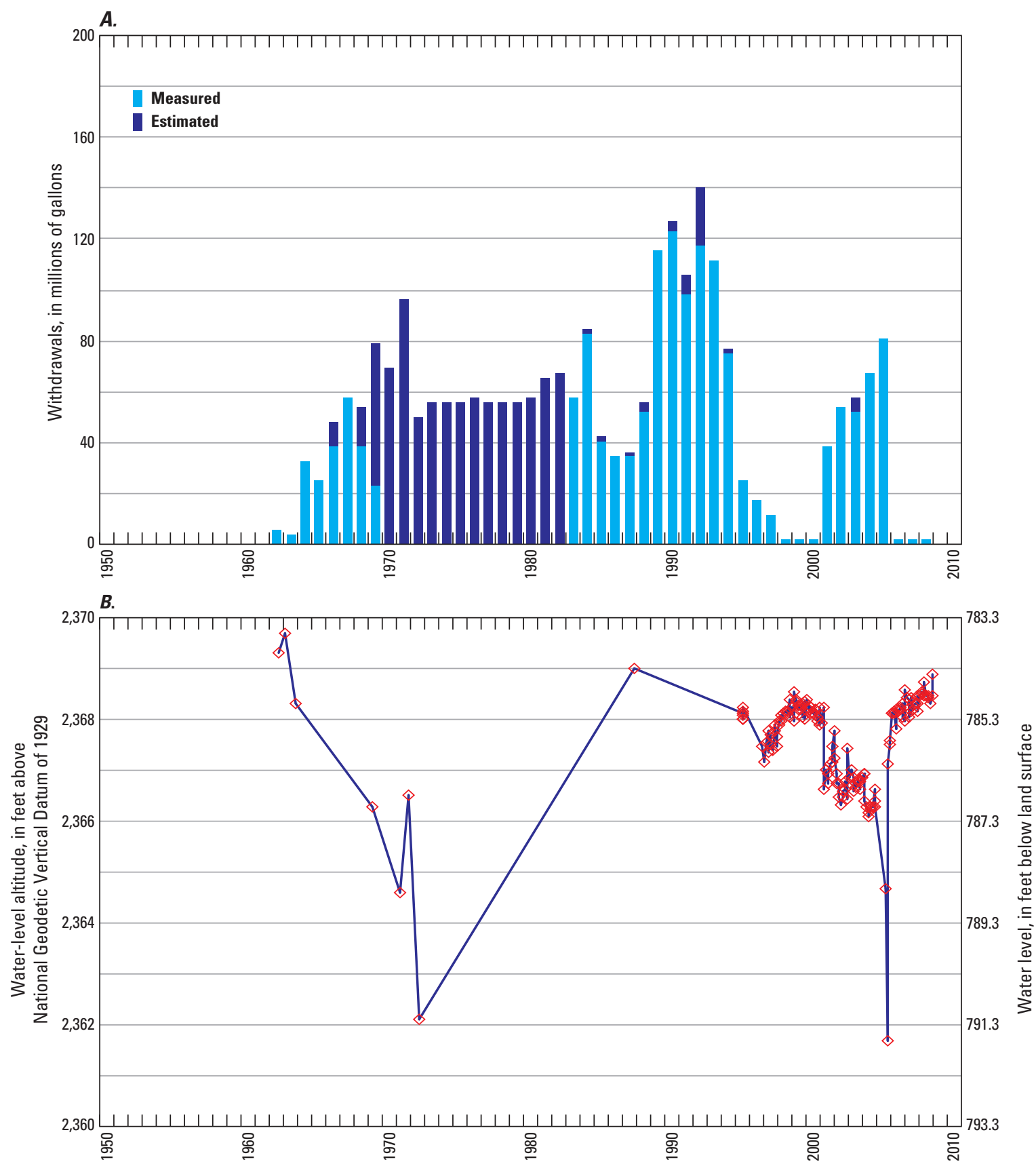

Figure 7. Groundwater withdrawals and water levels for well Army 1 WW (MV-1), Area 22, Nevada National Security Site, Nye County, Nevada, 1962-2008. 
ER-6-1-2.-ER-6-1-2 is on the southeastern edge of Yucca Flat in Area 6 of the NNSS (fig. 1; table 1; ER-6-1-2 photograph). Construction information for the borehole was compiled from Bechtel Nevada (2004). The borehole was drilled and completed to a depth of 3,200 ft below land surface in October 2002 using the rotary drilling method. Borehole diameter ranges from 36 in. at land surface to 12.25 in. at the bottom of the hole.

Borehole ER-6-1-2 has a single completion interval, well ER-6-1-2 main, which includes casing to a depth of $1,949 \mathrm{ft}$ and an open borehole to 3,200 ft (ig. 8). A piezometer string, containing a slotted interval from 1,526 to $1,587 \mathrm{ft}$, was installed in the annular space between the casing and borehole, and extends from land surface to a depth of 1,587 ft. Based on nearby borehole ER-6-1, the lithology at the saturated part of the open interval in well ER-6-1-2 main consists mostly of dolomite with some sandstone and quartzite (fig. 8; Wood,
2007). The carbonate rocks produce most of the water in the well (Bechtel Nevada, 2004, p. 5-13).

ER-6-1-2 primarily was drilled to be used as a pumping well in a multiple well aquifer test in the ER-6-1 well cluster (Bechtel Nevada, 2004). During 2003-04, about 78 Mgal of water were withdrawn from well ER-6-1-2 main (fig. 9A; appendix A). About $14 \mathrm{Mgal}$ of water were withdrawn in January 2003 and February 2004 for well development and testing and about $64 \mathrm{Mgal}$ of water were pumped during the aquifer test from April 24 to July 23, 2004 (Stoller-Navarro Joint Venture, 2005).

Periodic water-level measurements made in well ER-61-2 main since 2003 are shown in figure 9B. The water levels range from about 1,544 to $1,547 \mathrm{ft}$ below land surface. During the aquifer test from April to July 2004, the well was pumped at an average rate of 524 gal/min (Stoller-Navarro Joint Venture, 2005, p. 2-6). Water levels recovered by October 2004.

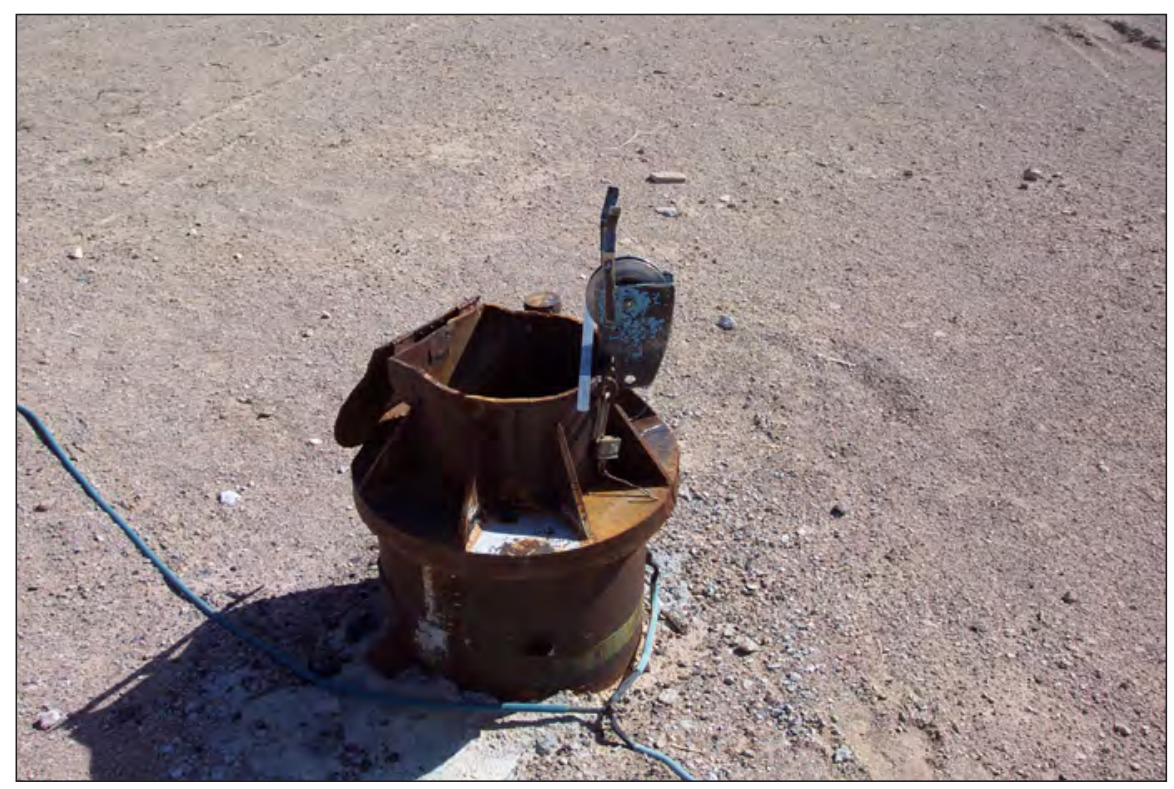

ER-6-1-2, April 2009. Photograph by Terry L. Miller, U.S. Geological Survey. 


\section{Well name: $E R-6-1-2$ main}

USGS site identification No.: 365901115593501

Land-surface altitude: 3,935 feet above National Geodetic Vertical Datum of 1929 (NGVD29)

Latitude: $36^{\circ} 59^{\prime} 02^{\prime \prime}$

Longitude: $115^{\circ} 59^{\prime} 35^{\prime \prime}$

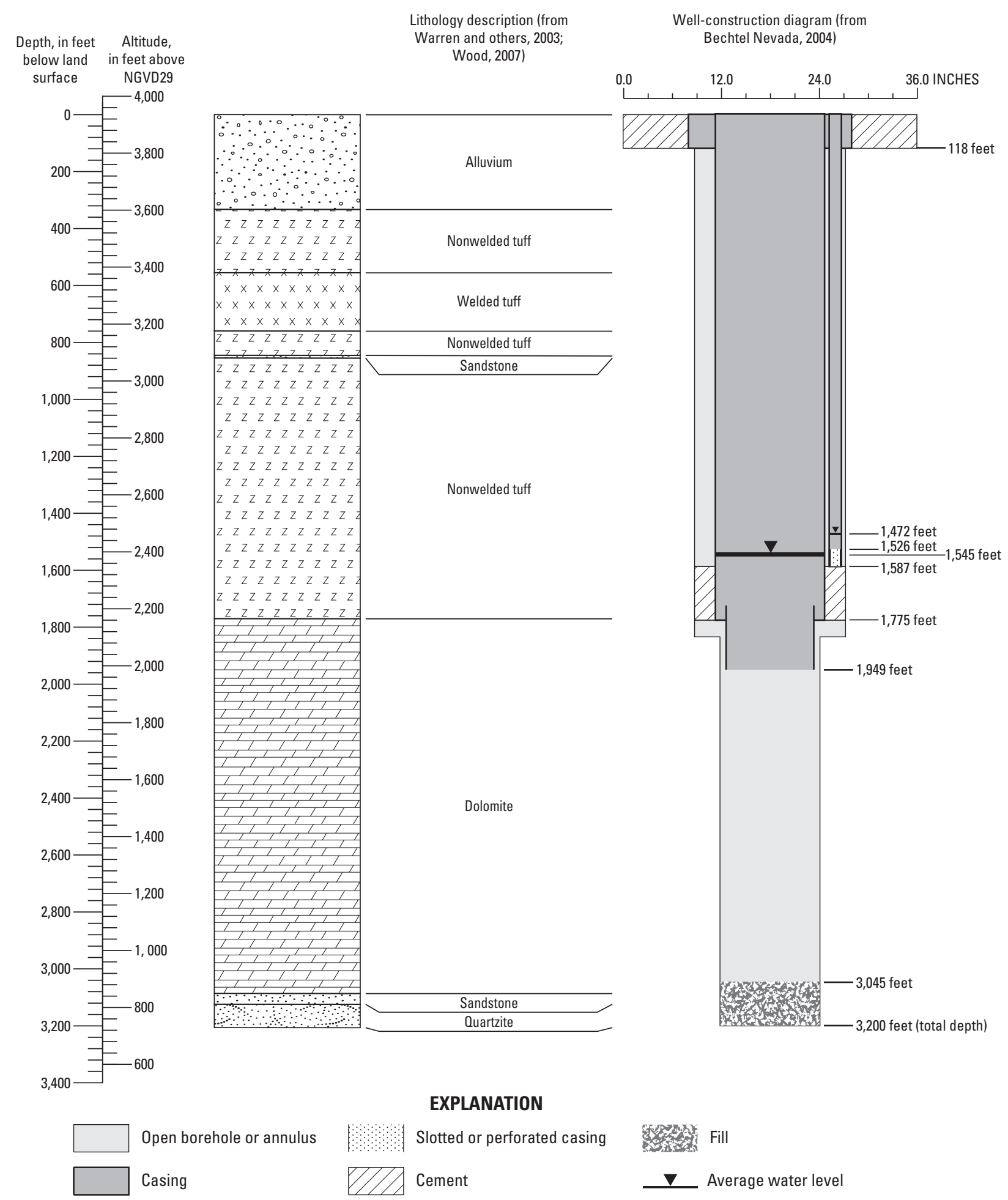

Figure 8. Borehole lithology and well construction for well ER-6-1-2 main, Area 6, Nevada National Security Site, Nye County, Nevada. 

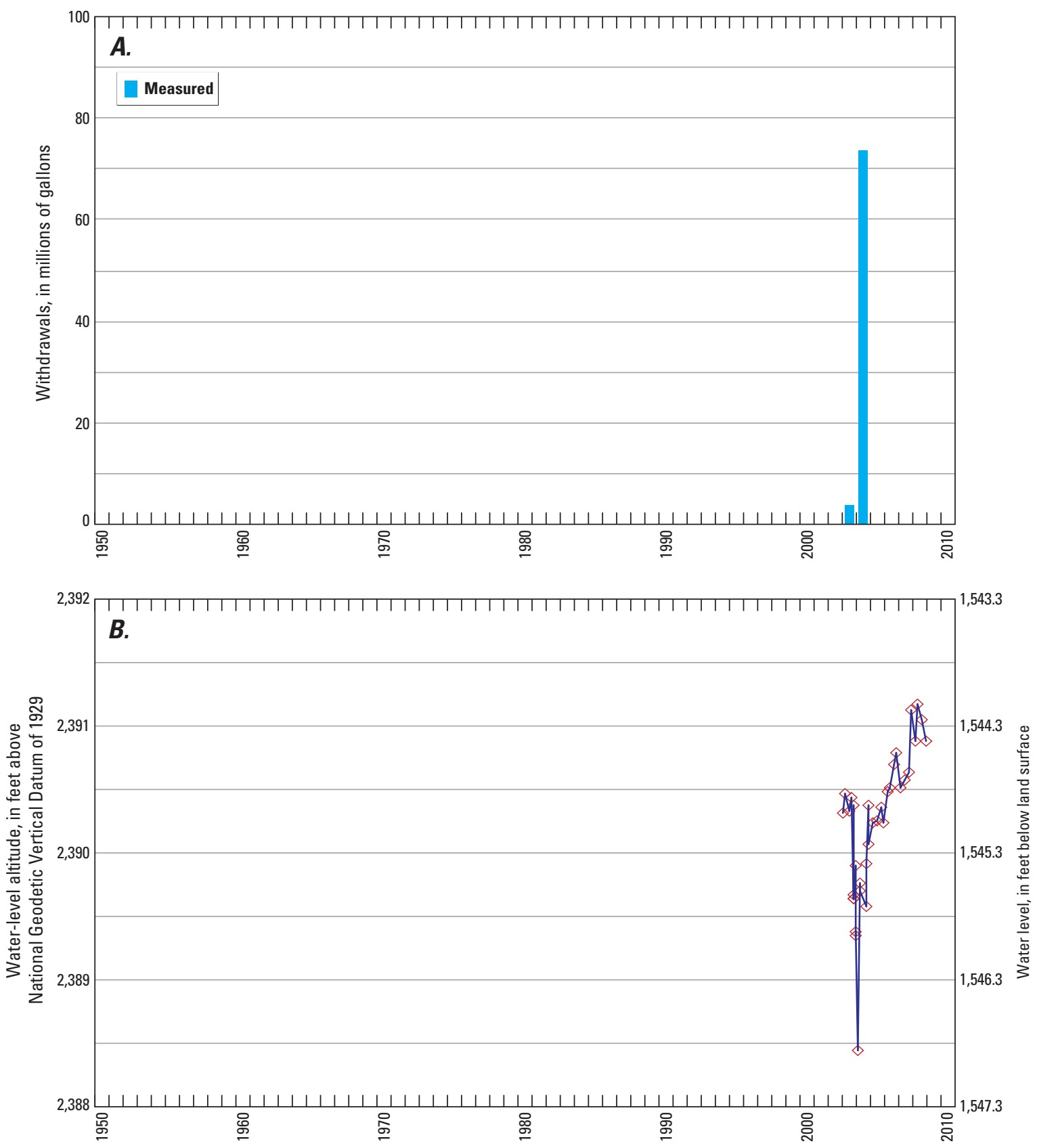

Figure 9. Annual groundwater withdrawals and water levels for well ER-6-1-2 main, Area 6, Nevada National Security Site, Nye County, Nevada, 2002-08. 
J-11 WW.-J-11 WW is in central Jackass Flats in Area 25 of the NNSS (ig. 1; table 1; J-11 WW photograph). Construction information for the borehole was compiled from Burns and McDonnell (1959). The borehole was drilled and completed to a depth of 1,327 ft below land surface in July 1957 using the cable-tool method. The diameter of the borehole is $15.75 \mathrm{in}$. from land surface to the bottom of the hole $(1,327 \mathrm{ft})$.

Borehole J-11 WW has a single completion interval, well $J-11 W W$, which is cased from land surface to a depth of $1,327 \mathrm{ft}$. The casing is perforated from 1,075 to $1,095 \mathrm{ft}$, and from 1,242 to 1,298 ft (fig. 10). The annular space between the casing and borehole is open from 16 to 1,327 ft. The lithology at the saturated part of the open interval consists of basalt and nonwelded and welded tuffs (fig. 10; Moore, 1962, p. 32-33). The well is open to two water-producing zones; the upper zone is in basalt at a depth of about 1,085 ft below land surface, and the lower zone is in the welded-tuff aquifer at a depth of about 1,285 ft (Burns and McDonnell, 1959; Young, 1972, p. 17).

J-11 WW was drilled to supply water for U.S. Atomic Energy Commission activities in Jackass Flats (Moore, 1962, p. 31). About $37 \mathrm{Mgal}$ of water were withdrawn from well J-11 WW from 1957 to 1962 (fig. 11A; appendix A). Corrosion of the well casing caused a decrease in water production in 1962 (Young, 1972, p. 17). The well was abandoned after an unsuccessful attempt to re-perforate the casing, and because of poor water quality.

Periodic water-level measurements made in well $J$-11 WW since 1958 are shown in figure $11 B$. The water levels range from about 1,039 to $1,042 \mathrm{ft}$ below land surface. Water levels from 1958 to 1973 are somewhat erratic, which may be a result of measurement error but overall, measurements have been very consistent for 50 years.

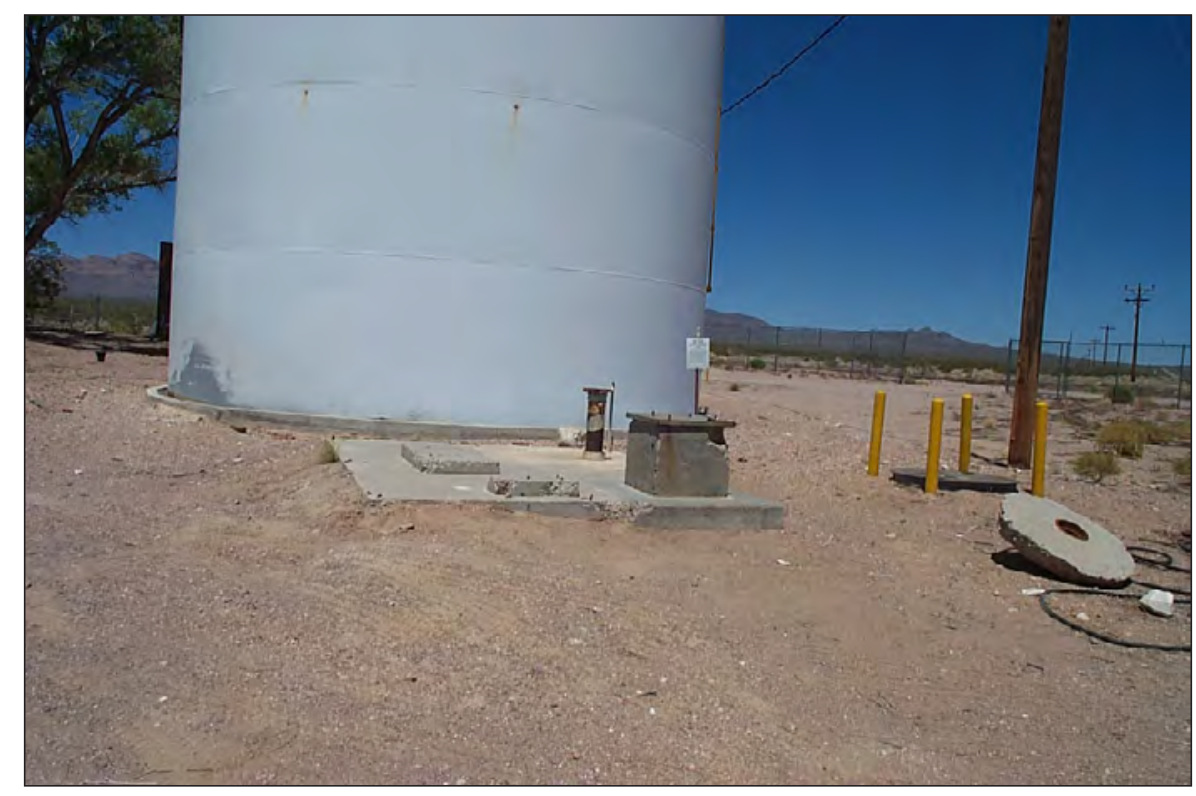

J -11 WW, June 2001. Photograph by Glenn L. Locke, U.S. Geological Survey. 
Well name: J-11 WW

USGS site identification No.: 364706116170601

Land-surface altitude: 3,443 feet above National Geodetic Vertical Datum of 1929 (NGVD29) Latitude:-

Longitude:-
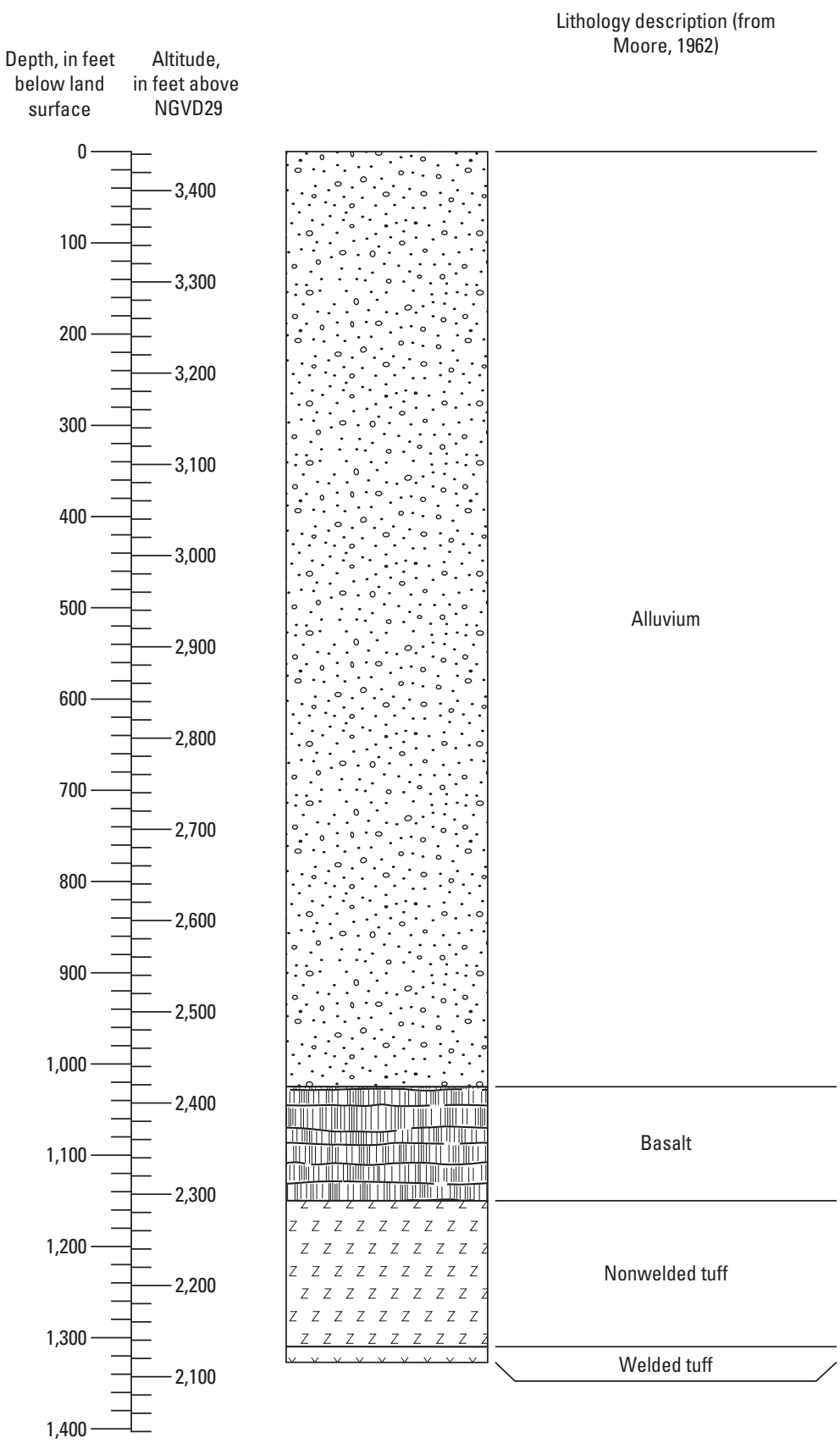

Well-construction diagram (from Burns and McDonnell, 1959)
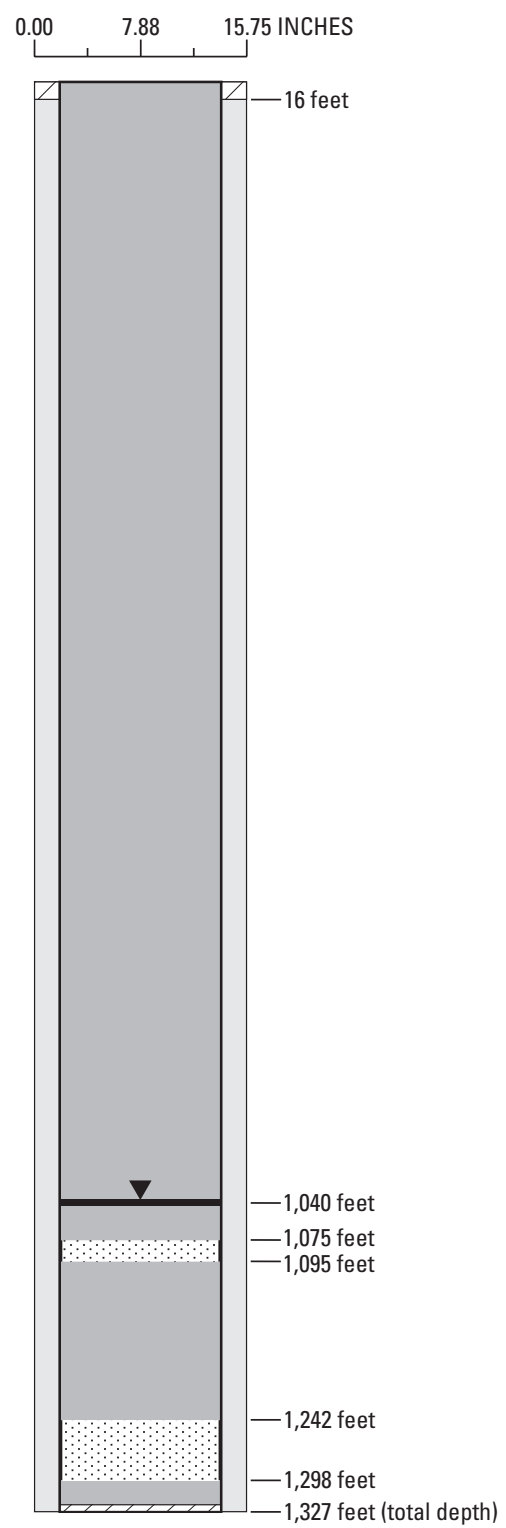

\section{EXPLANATION}

Open borehole or annulus

Casing
Slotted or perforated casing

Cement

Figure 10. Diagram showing borehole lithology and well construction for well J-11 WW, Area 25, Nevada National Security Site, Nye County, Nevada. 

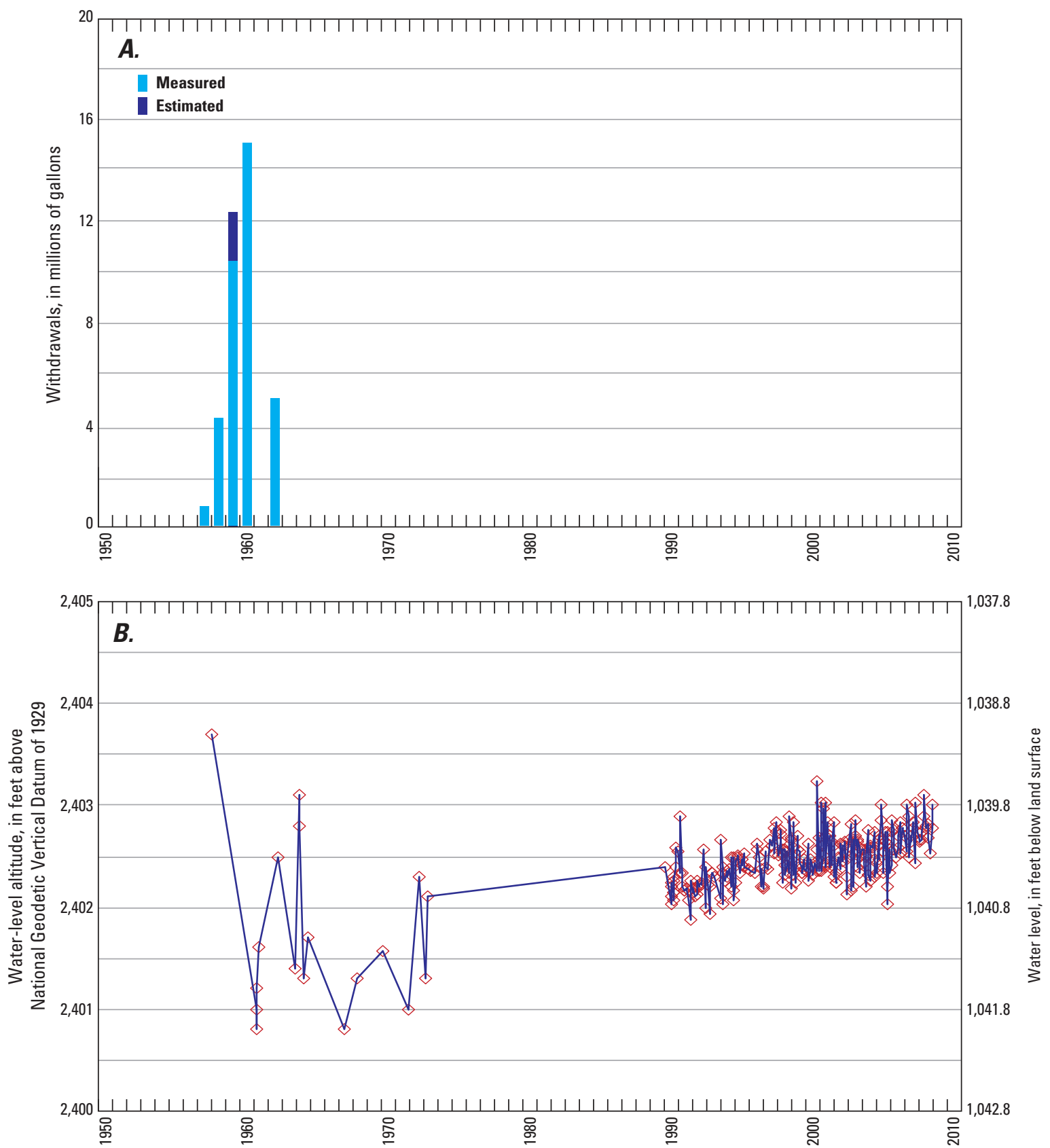

Figure 11. Annual groundwater withdrawals and water levels for well J-11 WW, Area 25, Nevada National Security Site, Nye County, Nevada, 1957-2008. 
J-12 WW.- - J-12 WW is on the southwestern edge of Jackass Flats in Area 25 of the NNSS (fig. 1; table 1; J-12 WW photograph). Construction information for the borehole was compiled from Burns and McDonnell (1959), Fenix \& Scisson, Inc., hole history data (written commun., 1988), and Bechtel Nevada (written commun., 2002). The borehole was drilled and completed to a depth of $885 \mathrm{ft}$ below land surface in October 1957 using the cable-tool method. In August 1968, the borehole was deepened to $1,139 \mathrm{ft}$, to open the hole to the entire thickness of the tuff aquifer (Thordarson, 1983, p. 50). Borehole diameter ranges from $15.75 \mathrm{in}$. from land surface to $885 \mathrm{ft}$, and $11.75 \mathrm{in}$. from 885 to $1,139 \mathrm{ft}$.

Borehole J-12 WW has two completion intervals, well $J-12 W W(885 \mathrm{ft}$ ) and well $J-12 W W$. In both wells, casing extends to a depth of $885 \mathrm{ft}$ below land surface with a perforated zone from 791 to $865 \mathrm{ft}$. The lithology at the saturated part of this open interval is welded tuff (fig. 12; Moore, 1962, p. 28-29; Claassen, 1973, p. 24). Both wells produced water from the welded-tuff aquifer (Young, 1972, p. 6, 17). Well $J-12 W W(885 \mathrm{ft}$ ) represents the borehole as it was completed in October 1957 (fig. 12A). In this first completion, the annular space between the casing and borehole in the well is open from 16 to $885 \mathrm{ft}$.

Well $J-12 W W$ represents the borehole as it was completed in August 1968 (fig 12B). In this second completion, the annular space between the casing and borehole is open from 16 to $885 \mathrm{ft}$, and the borehole is open from 885 to $1,139 \mathrm{ft}$.
J-12 WW was drilled as a water-supply well for U.S. Atomic Energy Commission activities in Jackass Flats (Moore, 1962, p. 27), and has been used as a source of water for site characterization activities at Yucca Mountain since the 1980s (La Camera and Westenburg, 1994, p. 30; U.S. Department of Energy, 2008, p. 2-6, 2-8). J-12 WW also has been part of DOE's hydrologic monitoring network since 1972 (Russell, 1989; Bechtel Nevada, 2003; U.S. Department of Energy, 2008, p. 7-6). More than 733 Mgal of water have been withdrawn from the borehole since October 1957 (fig. 13A; appendix A). Well $J-12 W W(885 \mathrm{ft}$ ) was pumped sporadically from October 1957 to July 1968, with a period of continuous pumping from November 1960 to June 1963. About 117 Mgal of water were withdrawn from well $J-12 W W(885 \mathrm{ft}$ ). Well $J-12 W W$ continued to be pumped sporadically from August 1968 to June 1980, and has been pumped continuously since then. About $617 \mathrm{Mgal}$ of water have been withdrawn from well $J-12 W W$.

Periodic water-level measurements made in J-12 WW since 1957 are shown in figure 13B. The water levels range from about 739 to $744 \mathrm{ft}$ below land surface in well $J-12 W W(885 \mathrm{ft}$ ), and 739 to $742 \mathrm{ft}$ below land surface in well $J-12 W W$. Water levels measured from 1957 to 1983 appear somewhat erratic, and could have been affected by measurement error or pumping. Fluctuations in water levels from 1983 to 2000 have been attributed to local pumping and recharge from precipitation (Fenelon and Moreo, 2002, p. 57). Since then, water levels show a rising trend amid continuous pumping in the well.

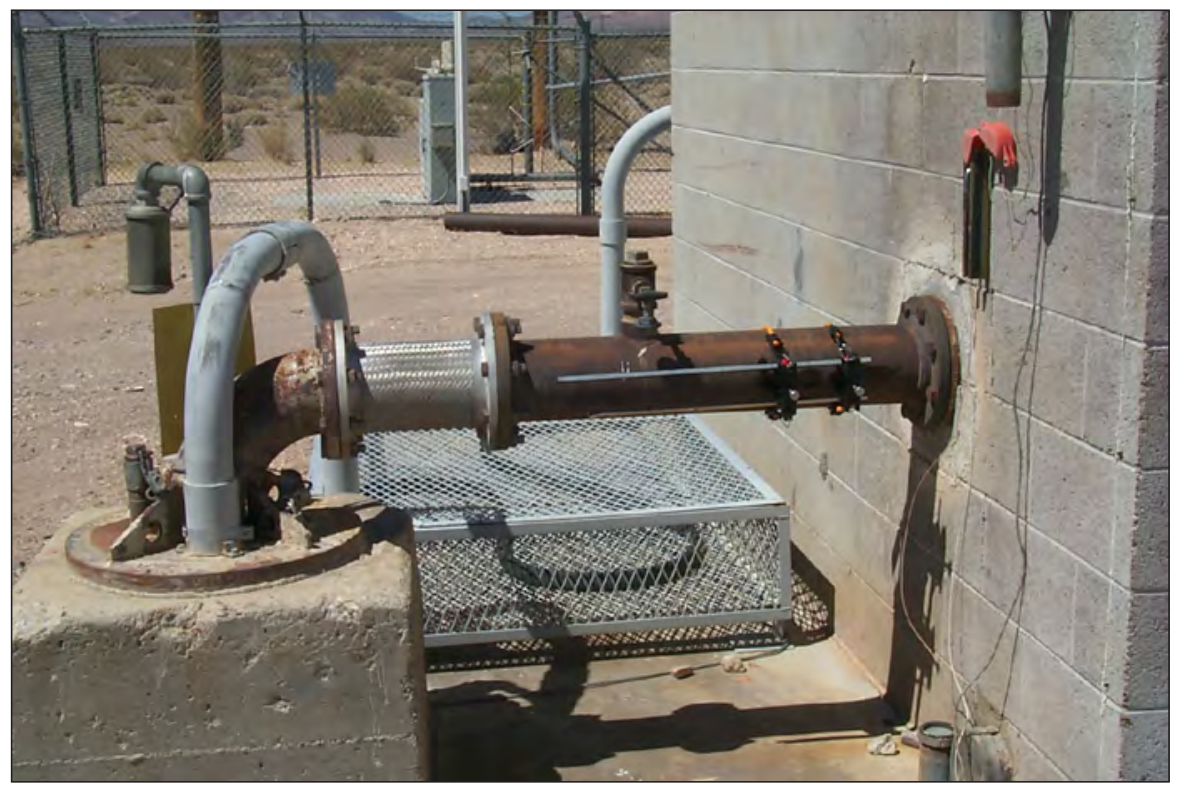

J -12 WW, July 2000. Photograph by Richard J. La Camera, U.S. Geological Survey. 
Well name: $J-12 W W(885 \mathrm{ft})$

USGS site identification No.: 364554116232400

Land-surface altitude: 3,128 feet above National Geodetic Vertical Datum of 1929 (NGVD29)

Latitude:-

Longitude:-
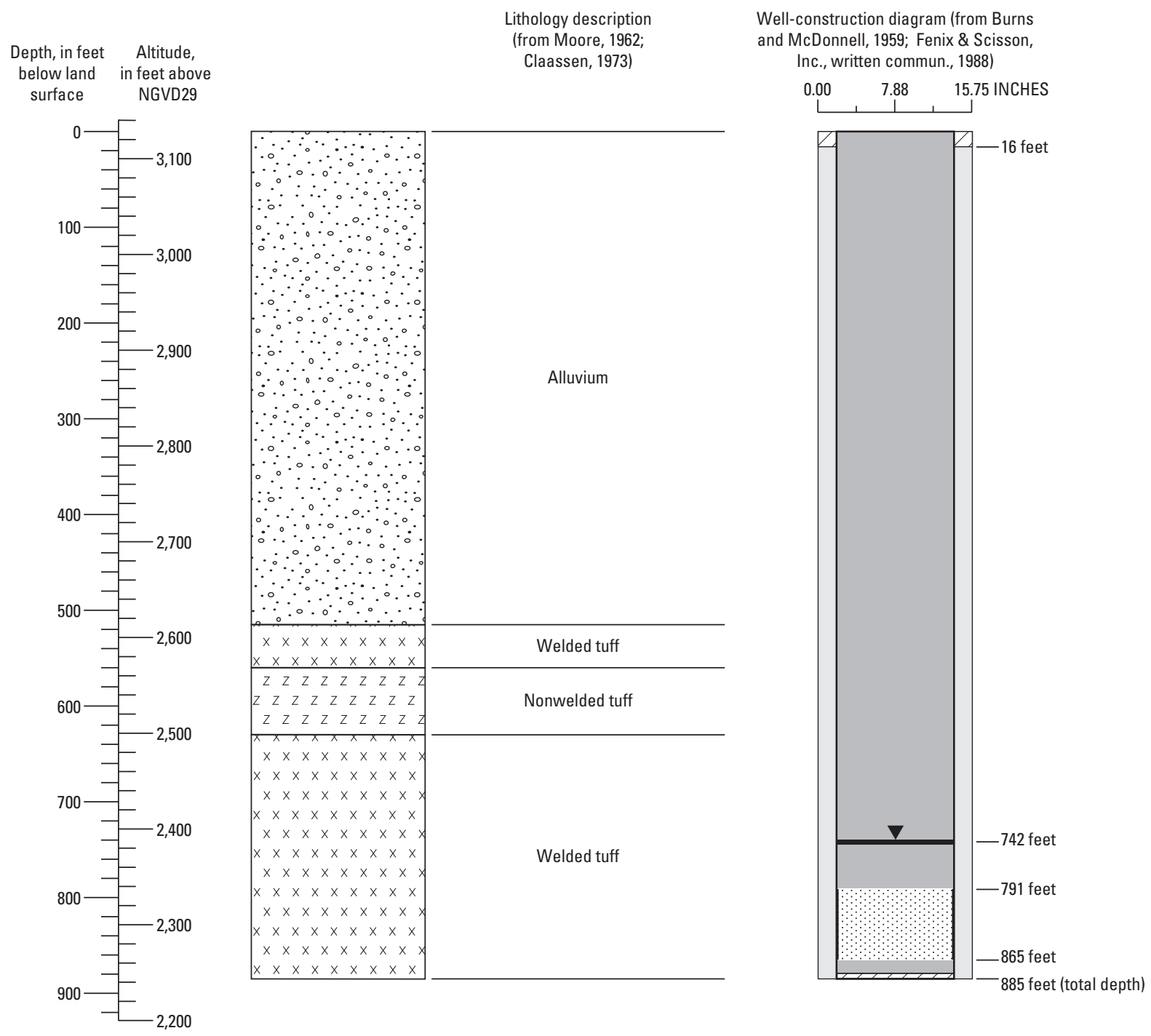

\section{EXPLANATION}

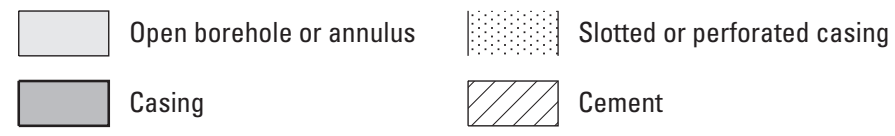

\section{A}

Figure 12. Borehole lithology and well construction for wells $J-12 W W(885 \mathrm{ft}$ ) and $\mathrm{J}-12 \mathrm{WW}$, Area 25, Nevada National Security Site, Nye County, Nevada. 


\section{Well name: $J-12 W W$}

USGS site identification No.: 364554116232401

Land-surface altitude: 3,128 feet above National Geodetic Vertical Datum of 1929 (NGVD29)

Latitude: -

Longitude: -

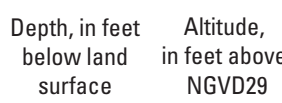

Lithology description (from

Moore, 1962: Claassen, 1973)
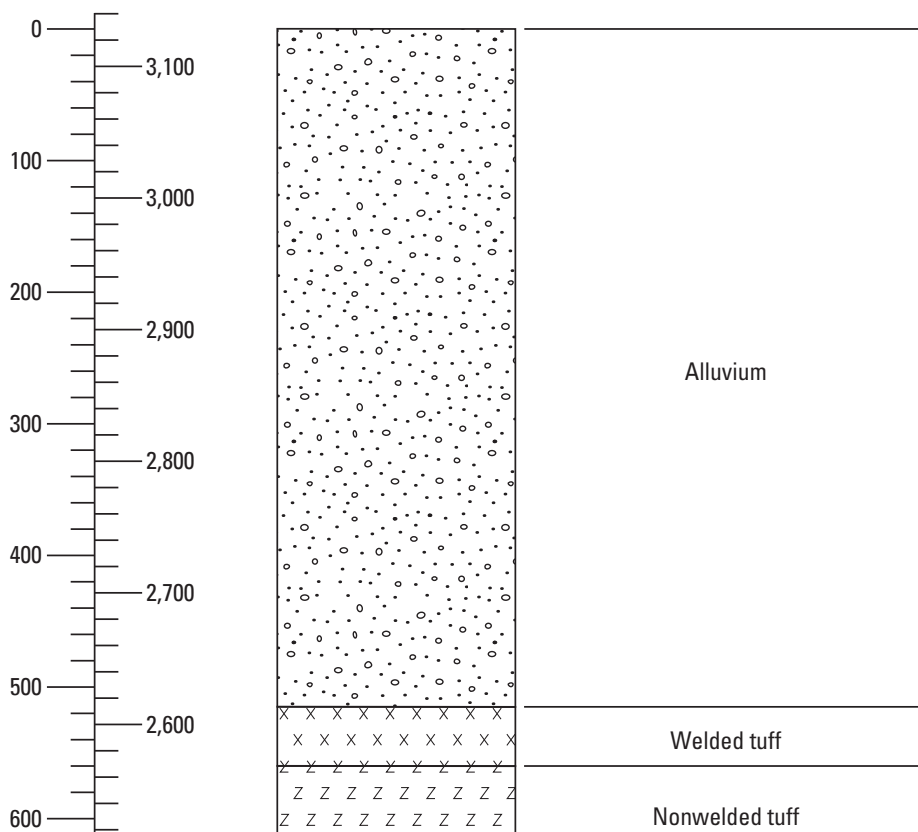

$\therefore 0^{\circ} \cdots$

$\because \because \because 0 \%$

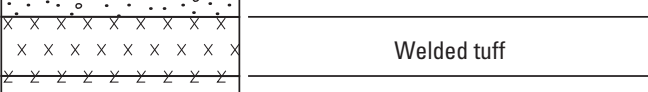

$\begin{array}{lllllll}z & z & z & z & z & z & z\end{array}$

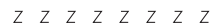

$\begin{array}{llllllllll}z & z & z & z & z & z & z & z & \end{array}$

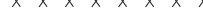

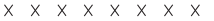

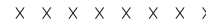

$x \times x \times x \times x \quad x$

$x \times x \times x \times x \times x$

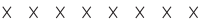

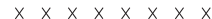

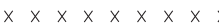

$x \times x \times x \times x$

$x \times x \times x \times x \times x$

$x \times x \times x \times x \quad x$

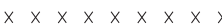

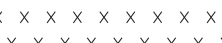

$x \times x \times x \times x \times x$

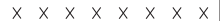

$x \times x \times x \times x \times x$

$x \times x \times x \times x \times$

$x \times x \times x \times x \times x \quad x \quad x \quad x \quad x$

$x \times x \times x \times x \times x$

$x \times x \times x \times x \times x$

$x \times x \times x \times x \times x$

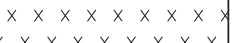

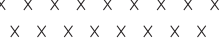

$x \times x \times x \times x$

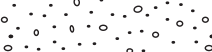

Well-construction diagram (from Burns and McDonnell, 1959; Fenix \& Scisson, Inc., written commun., 1988 Bechtel Nevada, written commun., 1990)

0.00
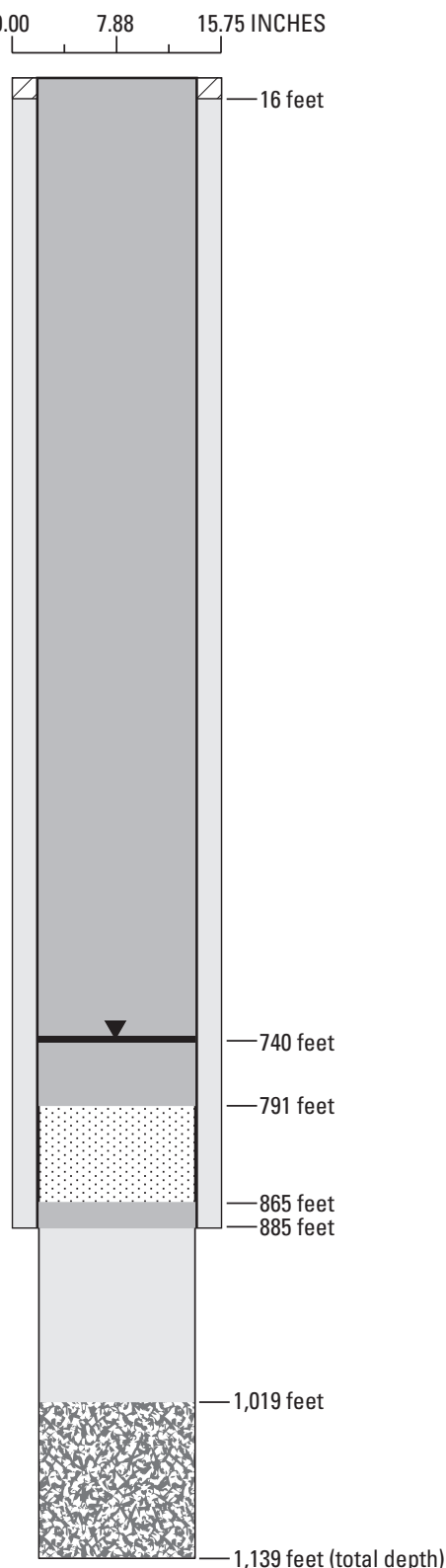

\section{EXPLANATION}

Open borehole or annulus

Casing
Slotted or perforated casing

Cement
Welded tuff

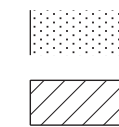

B

Figure 12.-Continued. 

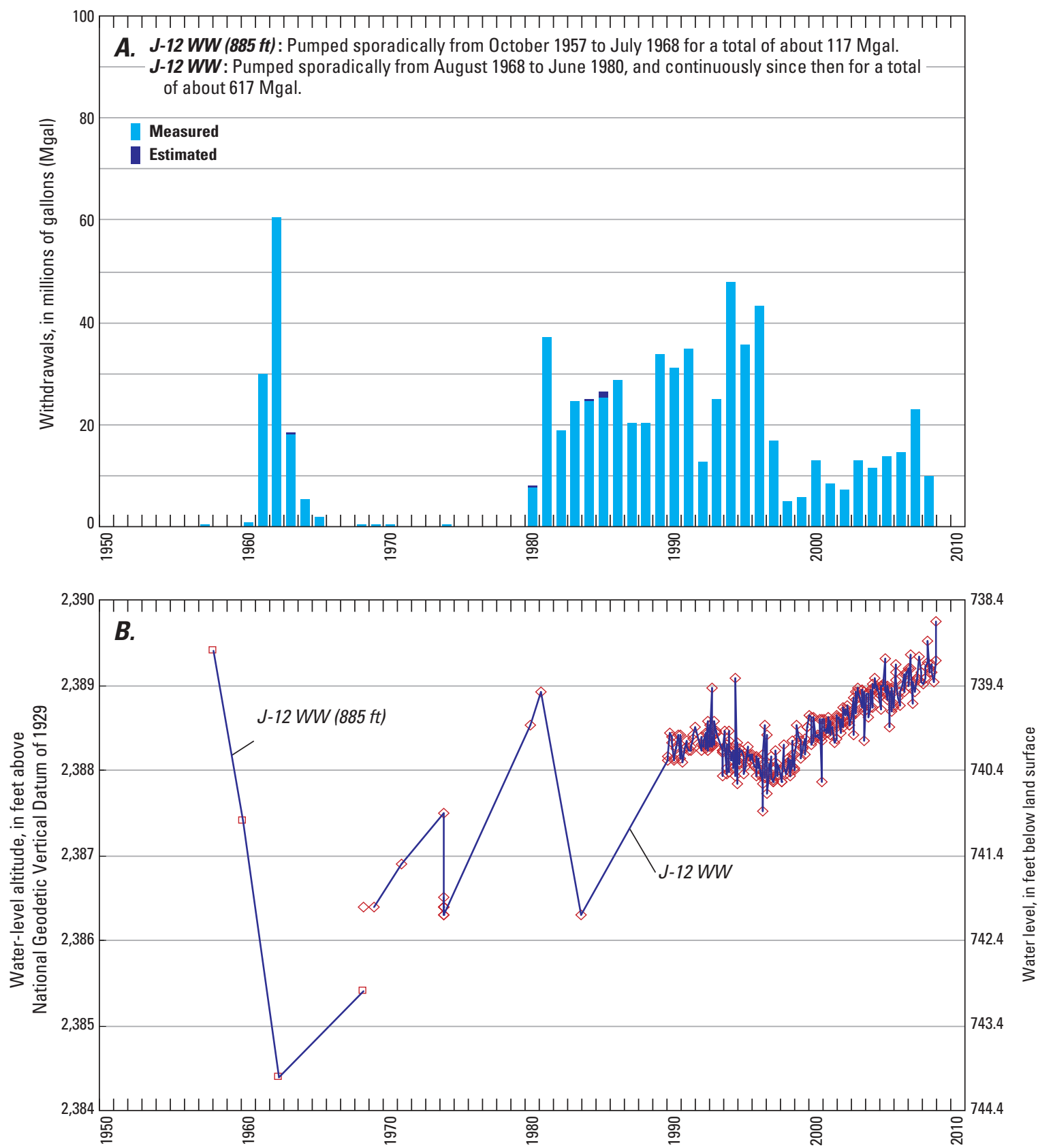

Figure 13. Annual groundwater withdrawals and water levels for wells $J-12 W W(885 \mathrm{ft})$ and J-12 WW, Area 25, Nevada National Security Site, Nye County, Nevada, 1957-2008. 
J-13 WW. - J-13 WW is on the western side of Jackass Flats in Area 25 of the NNSS (fig. 1; table 1; J-13 WW photograph). Construction information for the borehole was compiled from Doyle and Meyer (1963), Thordarson (1983), and Fenix \& Scisson, Inc., hole history data (written commun., 1988). The borehole was drilled and completed to a depth of 3,488 ft below land surface in December 1962 using hydraulic-rotary equipment (Doyle and Meyer, 1963, p. 1). The diameter of the borehole ranges from about 36 in. at land surface to $7.62 \mathrm{in}$. at the bottom of the hole $(3,488 \mathrm{ft})$.

Borehole J-13 WW has a single completion interval, well $J-13 W W$, which includes casing from land surface to a depth of 3,385 ft, with two perforated zones from 996 to $1,386 \mathrm{ft}$, and 2,690 to 3,312 ft (fig. 14). The annular space between the casing and borehole is open from 435 to about 1,390 ft and below a depth of 1,546 ft. The lithology at the saturated part of the open interval consists of alternating layers of welded and nonwelded tuffs (fig. 14; Doyle and Meyer, 1963, p. 8-11; Warren and others, 2003). Most water in the well originates from an interval between about 1,070 and 1,310 ft in the welded tuff - the major aquifer open to the well (Doyle and Meyer, 1963, p. 2; Young, 1972, p. 17).

J-13 WW originally was drilled to study the geology and hydrology of the NNSS (Doyle and Meyer, 1963, p. 1), particularly regional groundwater flow in the carbonate rocks in Jackass Flats (Thordarson, 1983, p. 2). However, the borehole did not penetrate carbonate rocks at a depth of 3,488 ft below land surface. Well $J-13 W W$ was used as a water supply to the Nuclear Rocket Development Station (NRDS) in Jackass Flats from 1964 to 1967 (Young, 1972, p. 17), and for site characterization activities at Yucca Mountain beginning in the 1980s (La Camera and Westenburg, 1994, p. 30; U.S. Department of Energy, 2008, p. 2-6, 2-8). The well also was part of DOE's hydrologic monitoring network from 1974 to 2006 (Russell, 1989; Bechtel Nevada, 2003; Wills, 2007, p. 4-5). About 1,320 Mgal of water were withdrawn from the well from 1962 to 2006 (ig. 15A; appendix A). About onehalf of this amount of water was pumped in the mid-1960s in support of the NRDS as estimated in Young (1972, p. 1, 13). Pumping ceased in well $J-13 W W$ in April 2006, and the well was deactivated in October 2008.

Periodic water-level measurements made in well $J$-13 WW since 1962 are shown in figure 15B. The water levels range from about 926 to $930 \mathrm{ft}$ below land surface. Water levels measured from 1962 to 1969 were affected by extensive pumping in the well (Young, 1972, p. 13; Thordarson, 1983, p. 20, 22). The measurements from 1971 to 1983 are somewhat erratic and could be caused by measurement error. Fluctuations in water levels from 1983 to 2000 have been attributed mostly to recharge from precipitation with lesser effects from decreased pumping in the well (Fenelon and Moreo, 2002, p. 57). Water levels after 2000, in general, continue to show the effects of decreased pumping in the well.

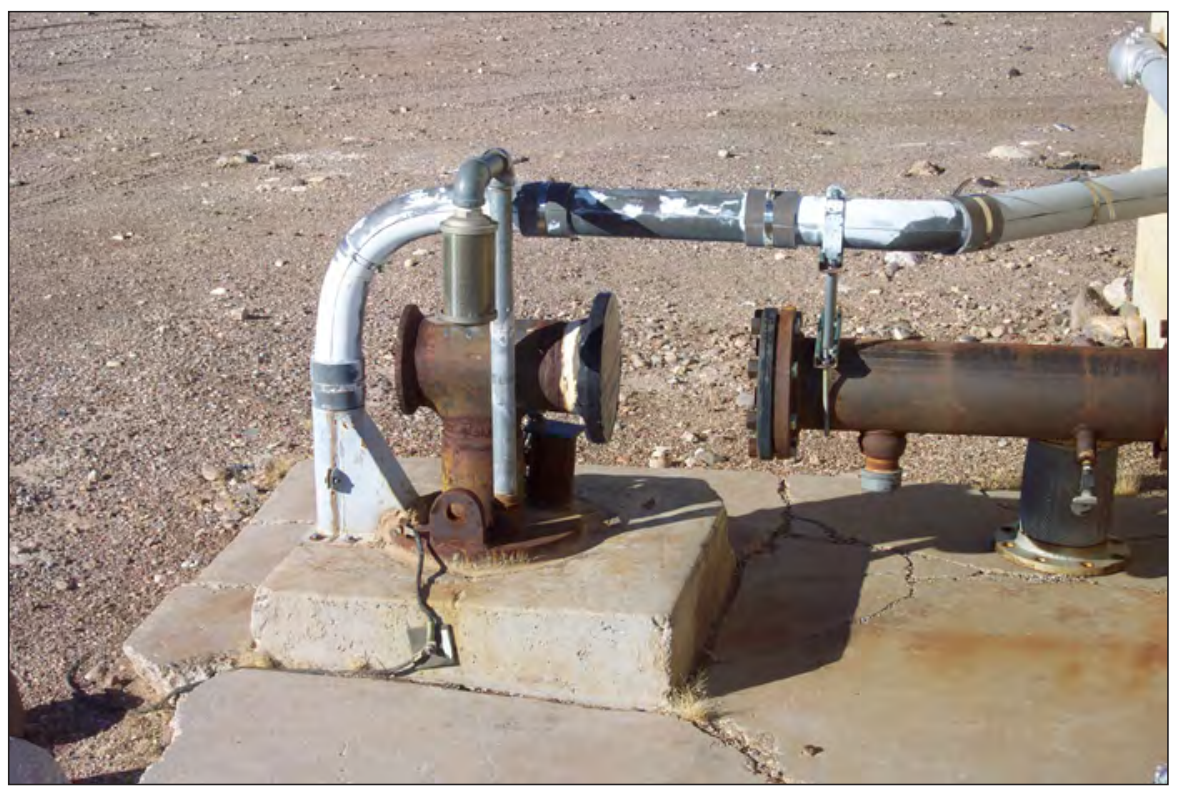

J -13 WW, April 2009. Photograph by Terry L. Miller, U.S. Geological Survey. 
Well name: J-13 WW

USGS site identification No.: 364828116234001

Land-surface altitude: 3,318 feet above National Geodetic Vertical Datum of 1929 (NGVD29)

Latitude:-

Longitude:-

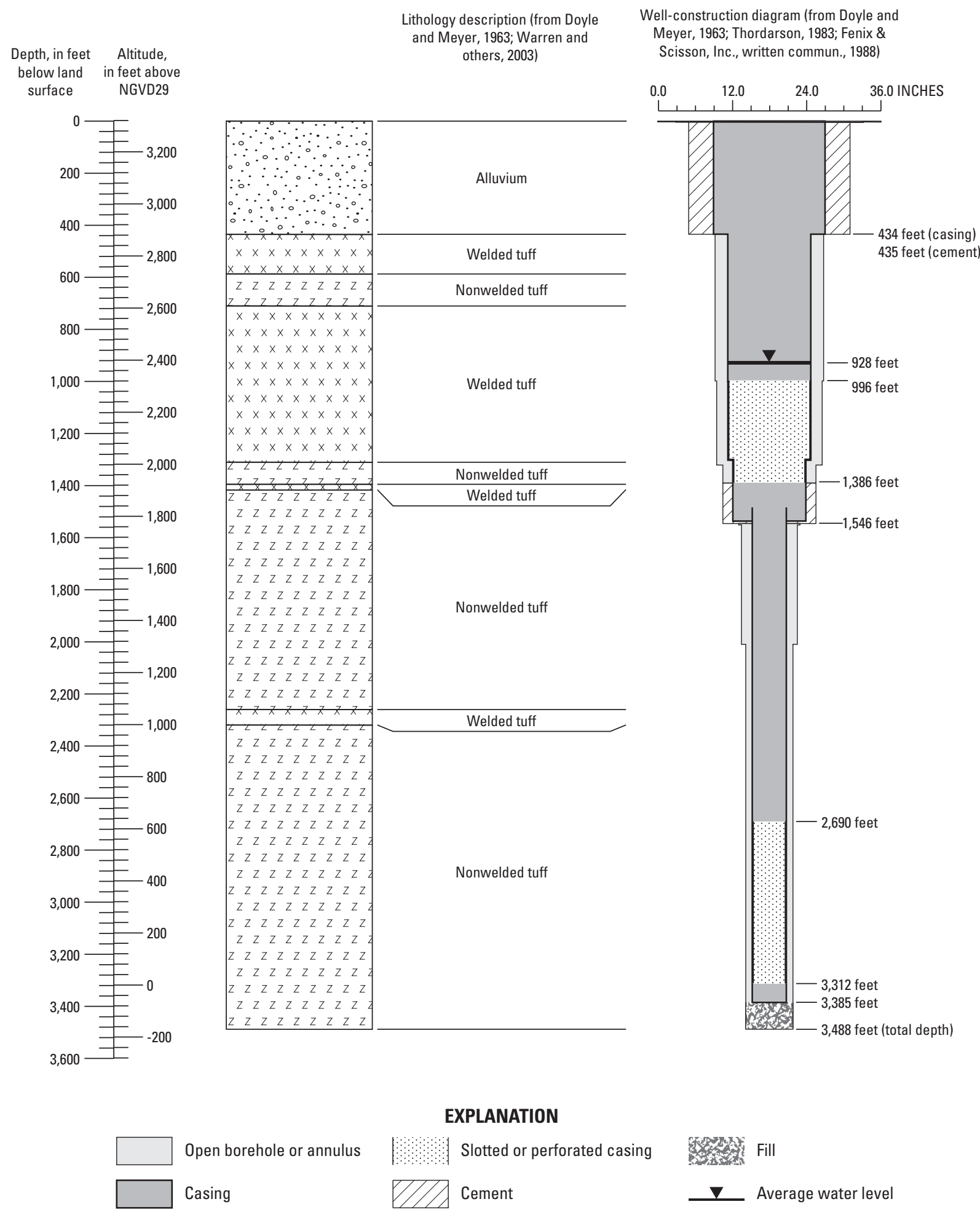

Figure 14. Borehole lithology and well construction for well J-13 WW, Area 25, Nevada National Security Site, Nye County, Nevada. 

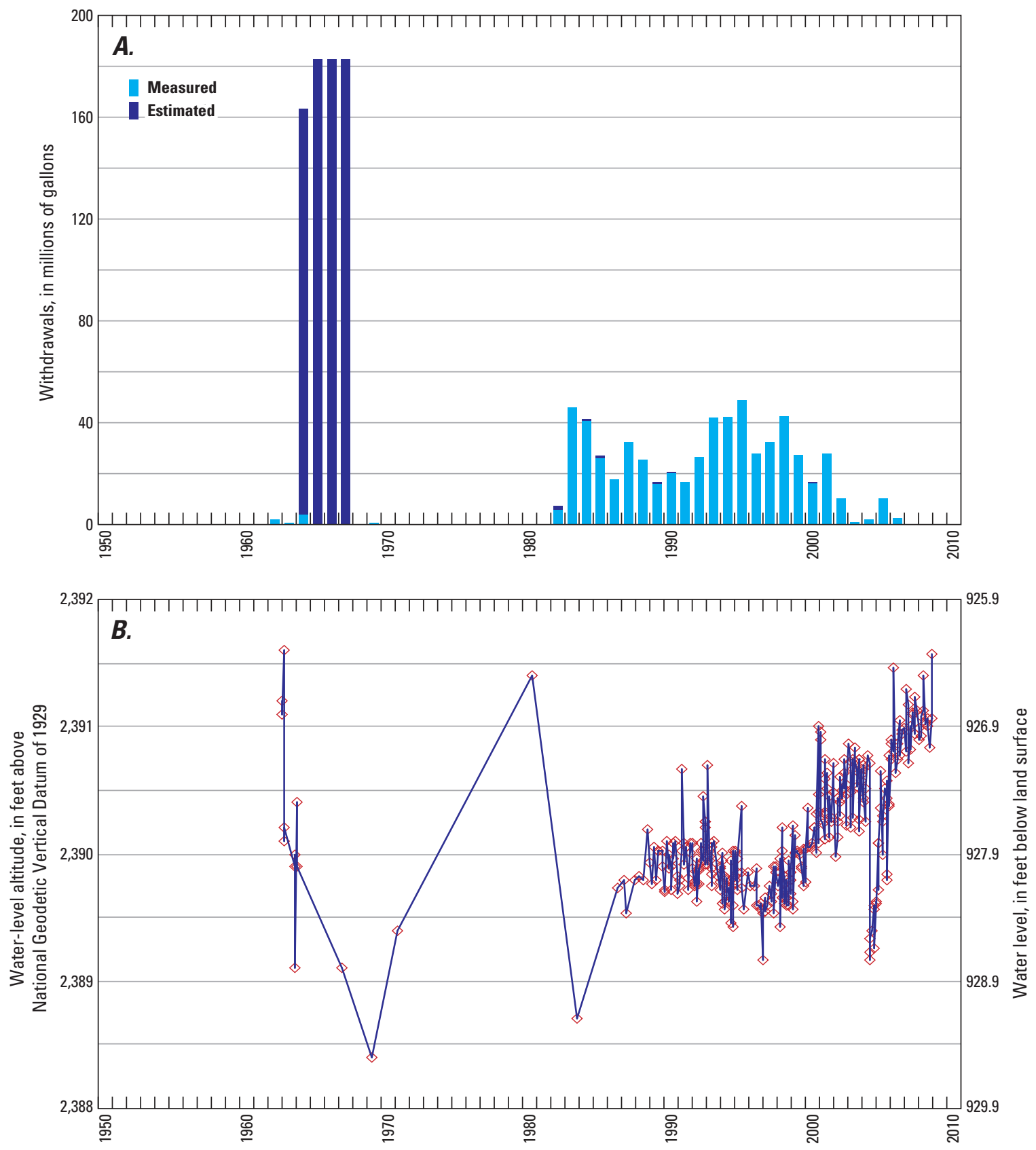

Figure 15. Annual groundwater withdrawals and water levels for well J-13 WW, Area 25, Nevada National Security Site, Nye County, Nevada, 1962-2008. 
RNM-2S. - RNM-2S is in Frenchman Flat in Area 5 of the NNSS (fig. 1; table 1; RNM-2S photograph). Construction information for the borehole was compiled from Fenix \& Scisson, Inc., hole history data (written commun., 1975), Gillespie and others (1996a), and Stoller-Navarro Joint Venture (2004). The borehole was drilled and completed to a depth of 1,156 ft below land surface in April 1974 (Fenix \& Scisson, Inc., written commun., 1975; Stoller-Navarro Joint Venture, 2004, p. 1-17) using the dual-reverse circulation drilling method with air and mud (Gillespie and others, 1996a, p. 66). Borehole diameter ranges from 64 in. at land surface to $17.5 \mathrm{in}$. at the bottom of the hole $(1,156 \mathrm{ft})$.

Borehole RNM-2S has a single completion interval, well $R N M-2 S$, which includes casing to a depth of $1,120 \mathrm{ft}$ with a slotted interval from 1,038 to 1,119 ft (ig. 16). The annular space between the casing and borehole is gravel packed from 690 to $1,120 \mathrm{ft}$ and open from 118 to $1,156 \mathrm{ft}$; the casing is not cemented below a depth of $118 \mathrm{ft}$. Two small diameter (1.9-in. outer diameter) piezometers were installed and welded to the 9 -in. casing that extends to a depth of 1,120 ft. The shallow piezometer extends from land surface to a depth of $954 \mathrm{ft}$, and the deeper piezometer extends from land surface to 1,038 ft. The lithology at the saturated part of the open interval consists entirely of alluvium (fig. 16), and thus the well produces water from the alluvial aquifer (Stoller-Navarro Joint Venture, 2004, p. 1-14).
RNM-2S was drilled to study radionuclide migration (the Cambric migration experiment; Bryant, 1992) in the saturated alluvium, and to replace RNM-2, which could not be completed because of excessive caving and collapse of the borehole (Gillespie and others, 1996a, p. 63, 66). In support of the migration test, well $R N M-2 S$ was pumped for about 16 years from October 1975 to August 1991 (Bryant, 1992, p. 7); during this time, almost 4,500 Mgal of water were withdrawn from the well (fig. 17A; appendix A). Well $R N M-2 S$ also was pumped in October 1999 for groundwater sampling (Davisson and others, 2001, p. 12) and from April to September 2003 as part of a multiple well aquifer test to help estimate hydraulic properties of the alluvium (Stoller-Navarro Joint Venture, 2004). More than $64 \mathrm{Mgal}$ of water were withdrawn from the well during the aquifer test in 2003.

Periodic water-level measurements made in well $R N M-2 S$ since 1974 are shown in figure $17 \mathrm{~B}$. The water levels range from about 719 to $738 \mathrm{ft}$ below land surface. Measurements from 1980 to 1991 show the effects of pumping in the well for the radionuclide migration experiment, which ceased in 1991. From 1991 to 1994, water levels rose about 3 feet. Since then, the water levels have been very consistent.

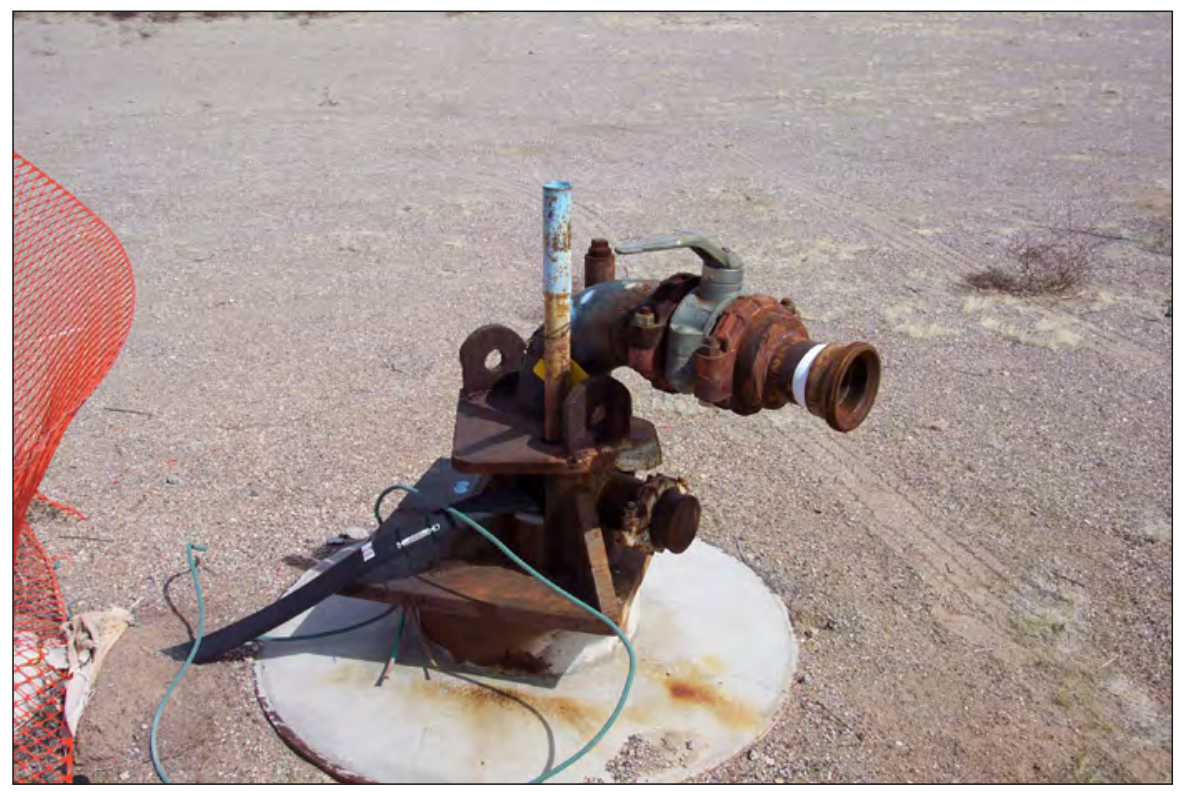

RNM- 2S, April 2009. Photograph by Terry L. Miller, U.S. Geological Survey. 
Well name: $R N M-2 S$

USGS site identification No.: 364922115580101

Land-surface altitude: 3,130 feet above National Geodetic Vertical Datum of 1929 (NGVD29)

Latitude: $36^{\circ} 49^{\prime} 22^{\prime \prime}$

Longitude: $115^{\circ} 58^{\prime} 01^{\prime \prime}$

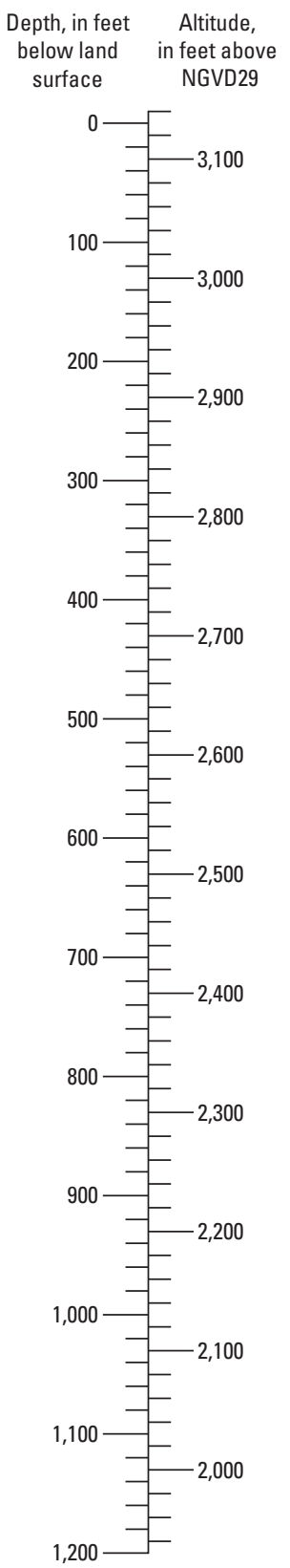

Lithology description (from Stoller-Navarro Joint Venture, 2004)
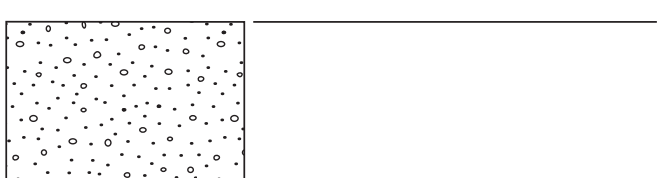

$\because 00000$

$\therefore \because \cdots 0$

$\because \because \because \cdots \because$

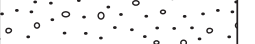

$\because \because \because 0 \%$

$\therefore \therefore \therefore \circ: \because$

$\therefore \therefore \therefore \therefore \therefore$

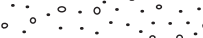

$\because \because \because \because \vdots$

$\therefore \cdots$

$\because \because \because \cdots$

$\because \therefore \because a$

$\therefore \quad \therefore \quad \because \because$

$\therefore \therefore \cdots$

$\because \because \because \cdots$

$\because \because \cdots$

$\therefore \quad \therefore \because \because$

$\therefore \because \therefore 00$

$\therefore \because$

$\because \because \because \cdots$

$\because \because \because \cdots$

$\because \therefore \circ$

$\therefore \because \cdots \cdots$

$\because \because \because \because \cdots$

$\because 00 \because \cdots$

$\because \because \because \because 0 \%$

$\because \because \therefore \therefore \circ \div$
Alluvium from Fenix \& Scisson, Inc., writte commun., 1975; Stoller-Navarro Joint Venture, 2004)
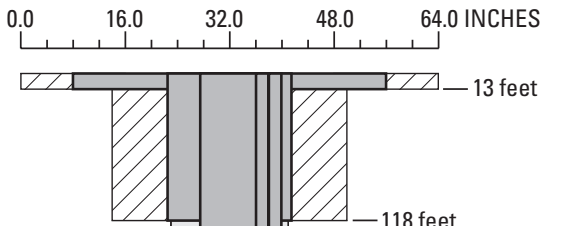

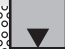

-690 feet

-724 feet

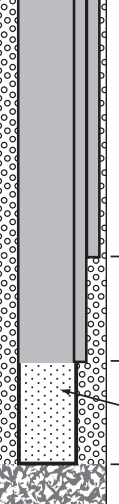

954 feet

$-1,038$ feet

1,038-1,119 feet (perforations)

$-1,120$ feet

$-1,156$ feet (total depth)

\section{EXPLANATION}

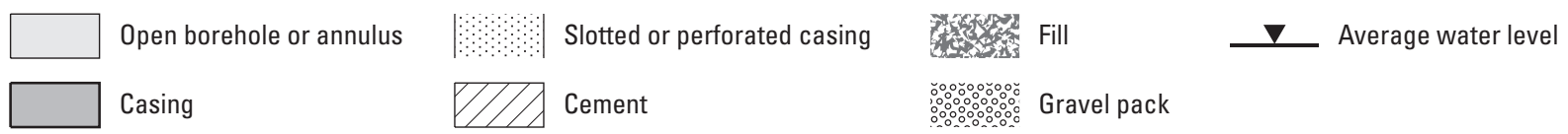

Figure 16. Borehole lithology and well construction for well RNM-2S, Area 5, Nevada National Security Site, Nye County, Nevada. 

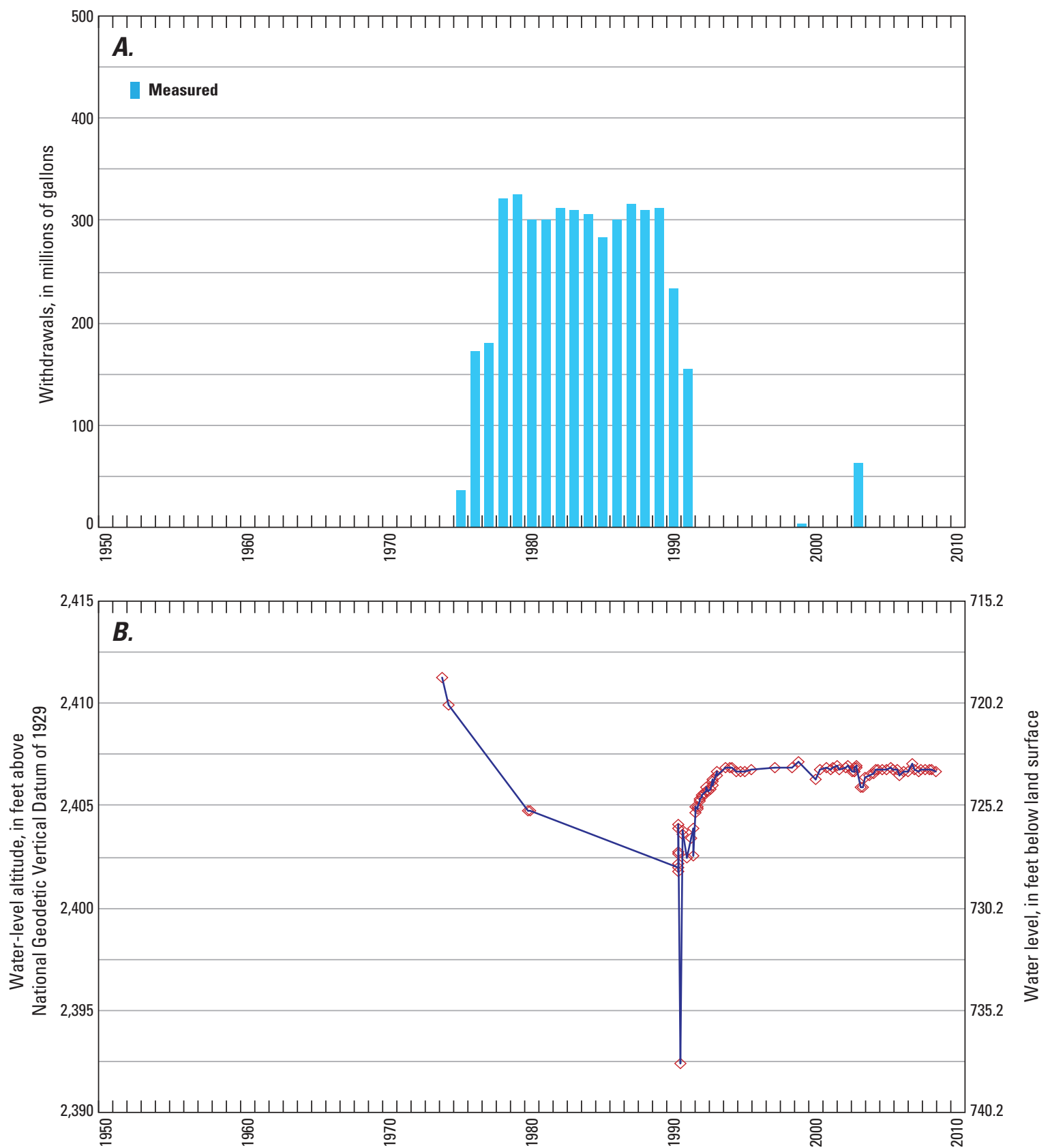

Figure 17. Annual groundwater withdrawals and water levels for well RNM-2S, Area 5, Nevada National Security Site, Nye County, Nevada, 1974-2008. 
U-20 WW.-U-20 WW is on Pahute Mesa in Area 20 of the NNSS (fig. 1; table 1; U-20 WW photograph). Construction information for the borehole was compiled from Fenix \& Scisson, Inc., hole history data (written commun., 1982). The borehole was drilled and completed to a depth of 3,268 ft below land surface in July 1982 using the conventional circulation drilling method with air foam. Borehole diameter ranges from 48 in. at land surface to 17.5 in. at the bottom of the hole.

Borehole U-20 WW has one completion interval, well $U-20 W W$ (cased), which includes casing to a depth of 3,199 ft with a slotted interval from 2,271 to 3,035 ft (fig. 18). The borehole is open below the casing to a depth of $3,268 \mathrm{ft}$, and the annular space between the casing and borehole is open below a depth of $65 \mathrm{ft}$. The lithology at the saturated part of the open interval consists mostly of alternating layers of lava and nonwelded tuff (fig. 18; Warren and others, 2003; Wood, 2007). Most water in the well comes from fractured rhyolite lava flows (Gillespie and others, 1996b, p. 55).
U-20 WW primarily has been used as a water supply for construction (Wood and Reiner, 1996, p. 8). Pumping in well U-20 WW (cased) began in July 1985 and continued through May 1996; the well has been pumped sporadically since then. The well also was monitored as part of DOE's hydrologic monitoring network from 1985 to 1999 (Russell, 1989; Townsend and Grossman, 2000, p. 5-5). Almost 775 Mgal of water have been withdrawn from the well, most of which occurred from 1985 to 1996 (fig. 19A; appendix A).

Periodic water-level measurements made in well $U-20$ WW (cased) since 1982 are shown in figure 19B. The water levels range from about 2,033 to 2,061 ft below land surface. Initial water levels represent pre-pumping conditions in the well, whereas measurements made after the well began pumping in 1985 show about $20 \mathrm{ft}$ of drawdown in the aquifer. Water levels were drawn down as much as $700 \mathrm{ft}$ (not shown in fig. 19B ) when the well was being pumped at a rate of about $280 \mathrm{gal} / \mathrm{min}$.

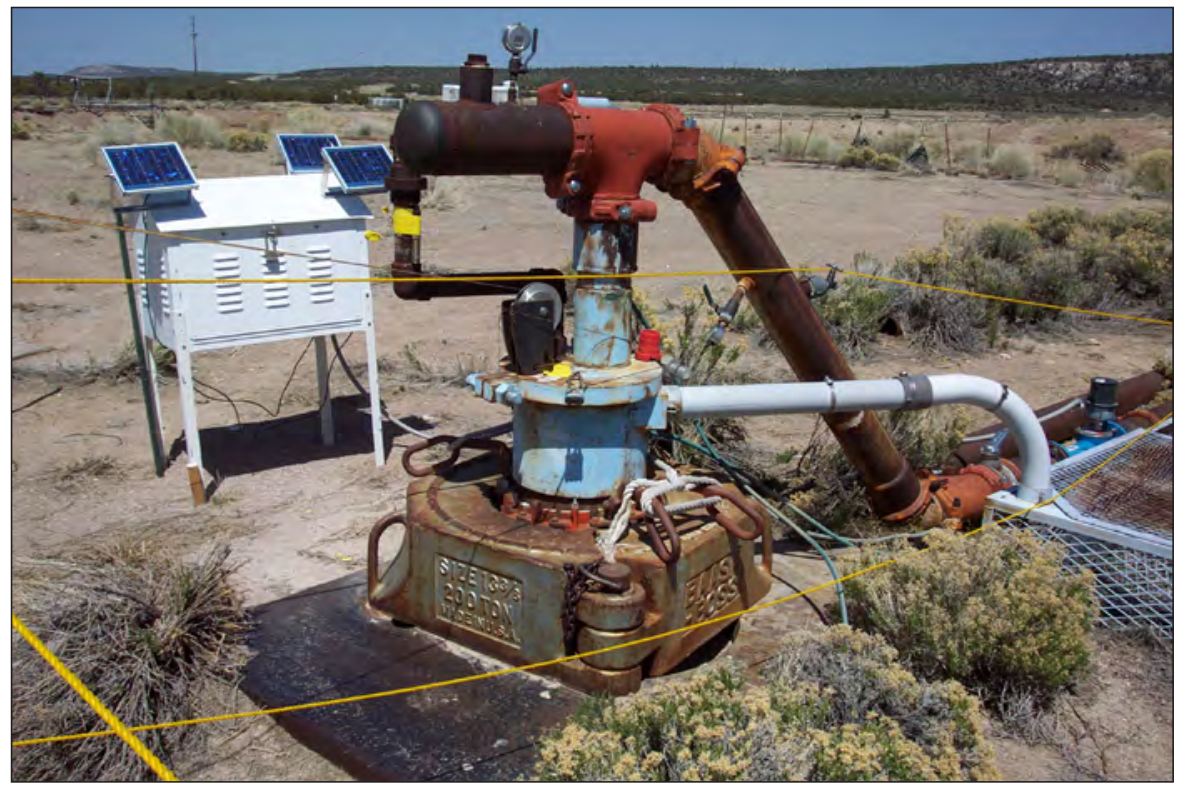

U -20 WW, April 2009. Photograph by Terry L. Miller, U.S. Geological Survey. 
Well name: $\boldsymbol{U}-20 \mathrm{WW}$ (cased)

USGS site identification No.: 371505116254501

Land-surface altitude: 6,468 feet above National Geodetic Vertical Datum of 1929 (NGVD29)

Latitude:-

Longitude:-

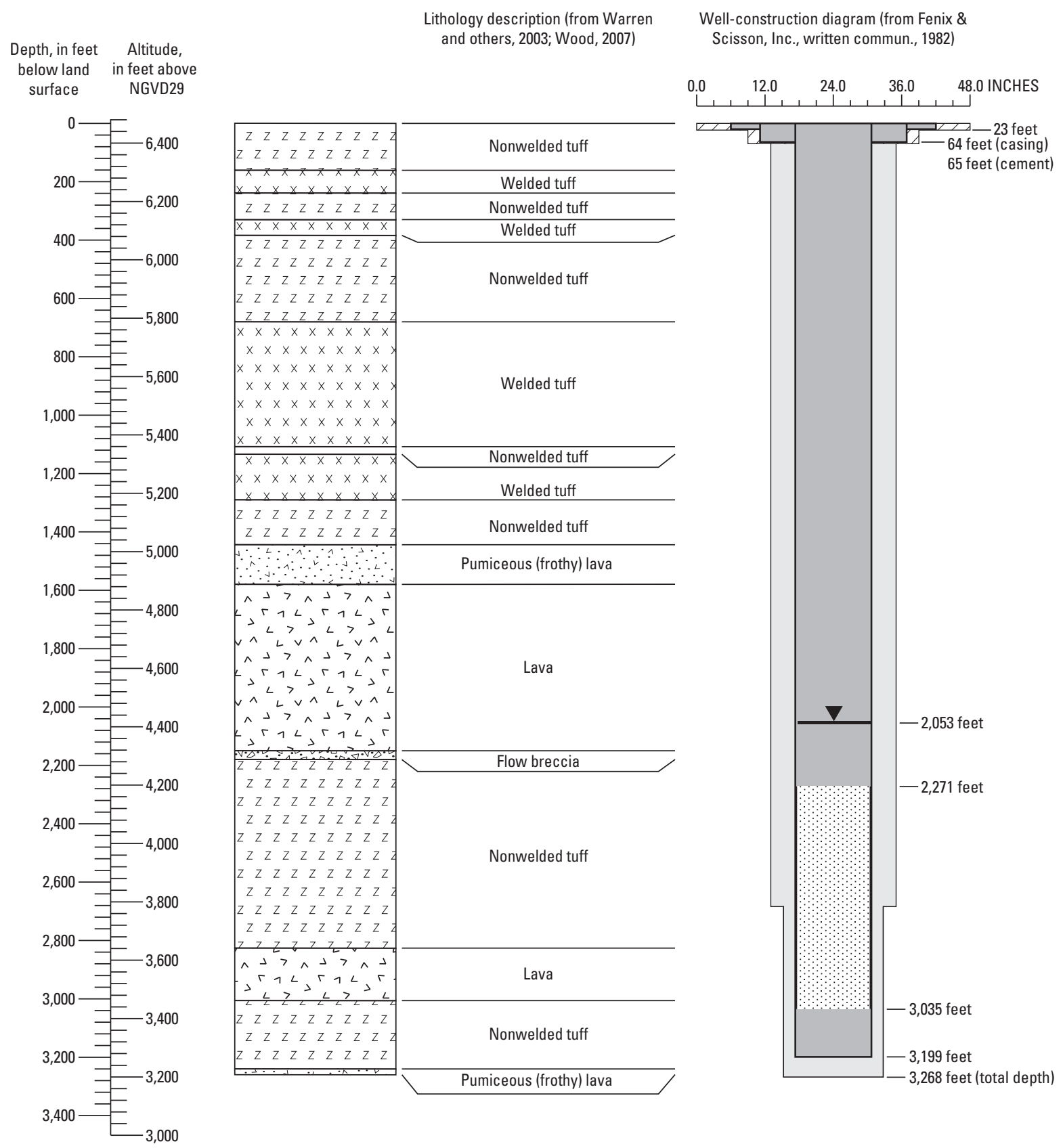

\section{EXPLANATION}

Open borehole or annulus Slotted or perforated casing

$\nabla$ Average water level

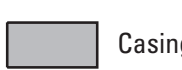

Cement

Figure 18. Borehole lithology and well construction for well U-20 WW (cased), Area 20, Nevada National Security Site, Nye County, Nevada. 

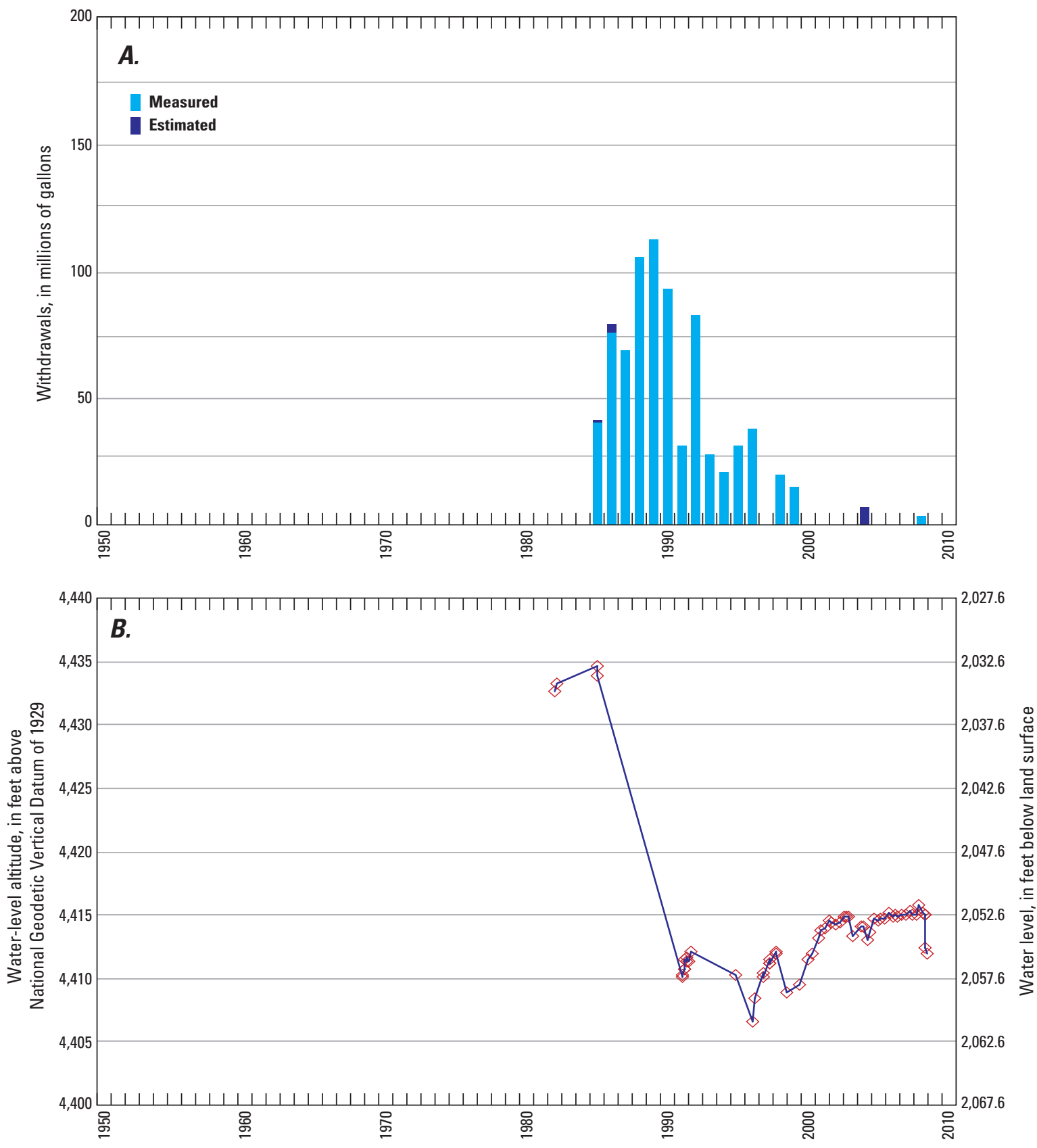

Figure 19. Annual groundwater withdrawals and water levels for well U-20 WW (cased), Area 20, Nevada National Security Site, Nye County, Nevada, 1982-2008. 
U-20a 2 WW.-U-20a 2 WW is on Pahute Mesa in Area 20 of the NNSS (fig. 1; table 1; U-20a 2 WW photograph not available). Construction information for the borehole was compiled from Fenix \& Scisson, Inc., hole history data (written commun., 1965), and Thordarson and others (1967). The borehole was drilled and completed to a depth of 4,500 ft below land surface in February 1964 using the air-rotary method. The borehole was planned for a total depth not to exceed 7,000 ft; however, the rhyolite lava encountered in the borehole was thicker than anticipated and drilling was stopped at a depth of 4,500 ft (D.L. Hoover and others, U.S. Geological Survey, written commun., 1964, p. 1). Borehole diameter ranges from 26 in. at land surface to 10.62 in. at the bottom of the hole.

Borehole U-20a $2 \mathrm{WW}$ has one completion interval, well $U$-20a $2 W W$, which includes casing to a depth of 2,369 ft, and an open borehole to 4,500 ft (ig. 20). The annular space between the casing and borehole is open below a depth of $860 \mathrm{ft}$. The lithology at the saturated part of the open interval consists mostly of lava with some nonwelded tuff (fig. 20; Wood, 2007). Three major water-producing zones occur within the lava from 2,404 to 2,682 ft; 2,895 to 3,085 ft; and 3,648 to 3,838 ft (R.K. Blankennagel and J.E. Weir, U.S. Geological Survey, written commun., 1965, p. 16).

U-20a 2 WW originally was drilled as a satellite hole, and to determine subsurface geology of the borehole (D.L. Hoover and others, U.S. Geological Survey, written commun., 1964, p. 1). Well U-20a $2 W W$ was used for water supply from August 1964 to December 1969, and was monitored as part of DOE's hydrologic monitoring network from 1973 to 1975 (Russell, 1989; Lyles, 1990). About 130 Mgal of water were withdrawn from the well from 1964 to 1969 (fig. 21A; appendix A). Withdrawal data are not available for 1970-76, but are assumed to be zero. The well was plugged to the surface with cement in January 1976 (Bechtel Nevada, written commun., 2002).

Water-level measurements made in well $U$-20a $2 \mathrm{WW}$ from 1964 to 1975 are shown in figure $21 B$. The water levels range from about 2,058 to 2,066 ft below land surface. During periods of pumping, water levels (not shown in fig. 21B) were drawn down as much as $23 \mathrm{ft}$ at an average pumping rate of $186 \mathrm{gal} / \mathrm{min}$, but recovered in less than 24 hours after the pump was shut off. 
Well name: $U$-20a $2 W W$

USGS site identification No.: 371434116251601

Land-surface altitude: 6,472 feet above National Geodetic Vertical Datum of 1929 (NGVD29)

Latitude: $37^{\circ} 14^{\prime} 34^{\prime \prime}$

Longitude: $116^{\circ} 25^{\prime} 16^{\prime \prime}$

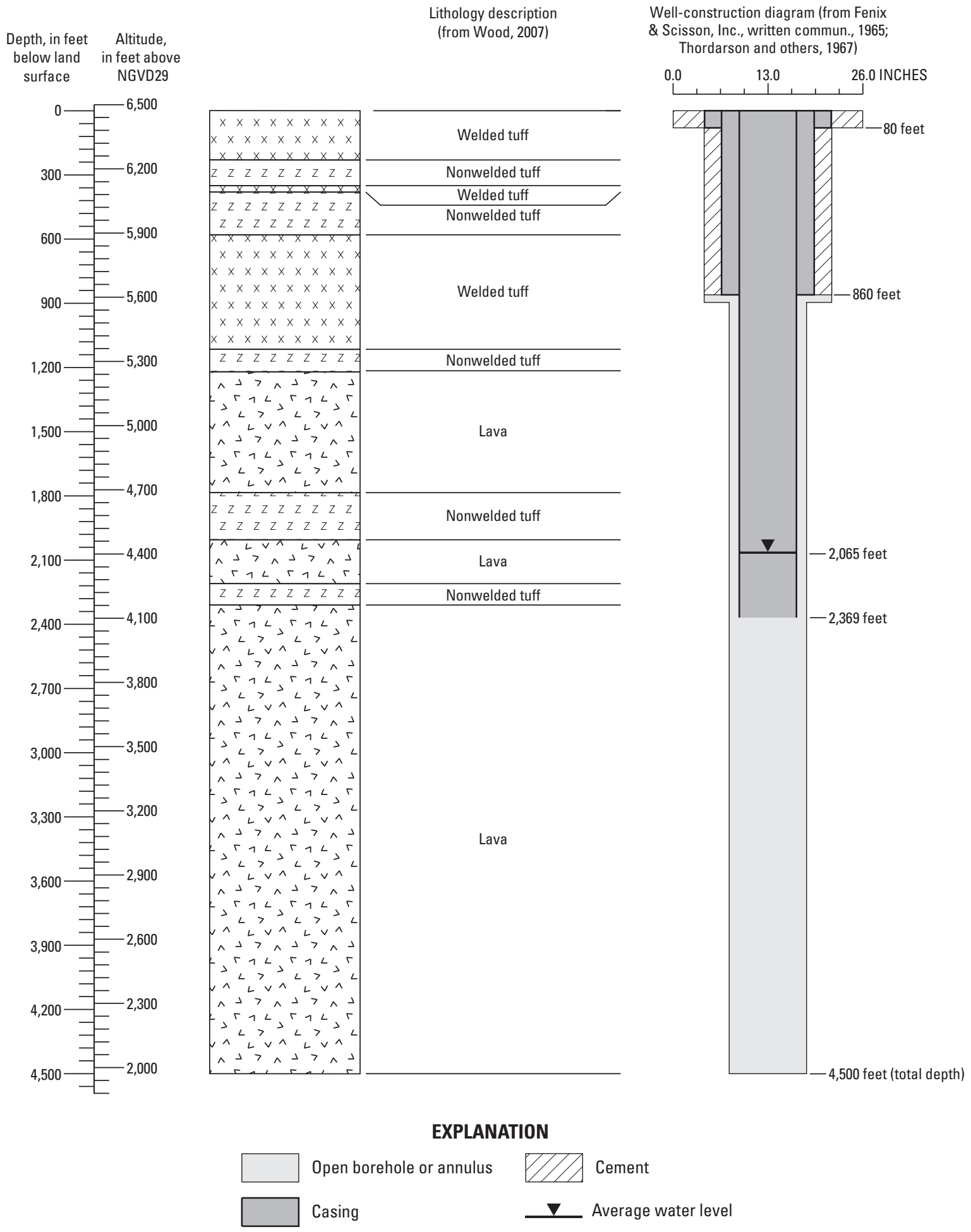

Figure 20. Borehole lithology and well construction for well U-20a 2 WW, Area 20, Nevada National Security Site, Nye County, Nevada. 

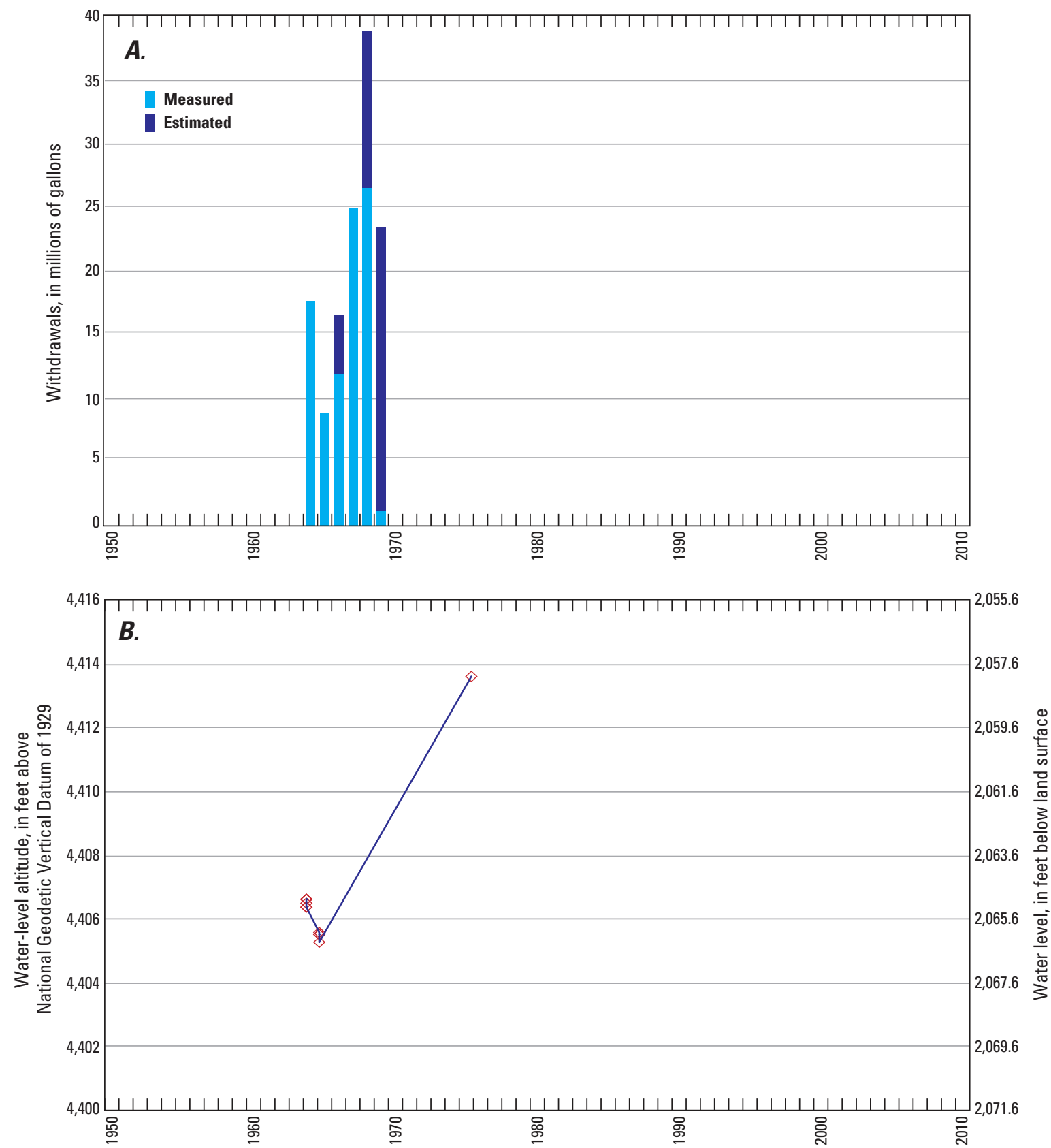

Figure 21. Annual groundwater withdrawals and water levels for well U-20a 2 WW, Area 20, Nevada National Security Site, Nye County, Nevada, 1964-76. 
U-20n PS 1DD-H.-U-20n PS 1DD-H is on Pahute Mesa in Area 20 of the NNSS (fig. 1; table 1; U-20n PS 1DD-H photograph). Construction information for the borehole was compiled from Fenix \& Scisson, Inc., hole history data (written commun., 1976) and Fenix \& Scisson, Inc., (written commun., 1989). The original borehole was drilled to a depth of 4,172 ft in April 1976 using the conventional circulation method with air foam and mud. Several unsuccessful attempts were made to sidetrack the borehole and drill through the cavity of the Cheshire nuclear test (Sawyer and others, 1999). The previous sidetrack holes were sealed with cement, and a successful sidetrack was begun at a depth of 3,113 ft below land surface. This sidetrack hole was drilled, using the conventional circulation method with mud, at an average inclination of about 21 degrees from the vertical to a total measured depth of 4,520 ft and a true vertical depth of 4,280 ft (Sperry-Sun, written commun., 1976; Sawyer and others, 1999, p. 15). Measured (slant) depths are used hereafter when referring to U-20n PS 1DD-H, except for water levels, which are reported as true vertical depths. Borehole diameter ranges from $117 \mathrm{in}$. at land surface to $9.88 \mathrm{in}$. at the bottom of the hole $(4,520 \mathrm{ft})$.

Borehole U-20n PS 1DD-H has three completion intervals, well $U$-20n PS 1DD-H (4309 ft), well U-20n PS $1 D D-H$ (3025 ft), and well U-20n PS 1DD-H (recompl). Well $U$-20n PS $1 D D-H$ (4309 ft) represents the borehole as it was completed in August 1983. This first completion contains casing to a depth of 4,495 ft with perforations from 4,202 to $4,285 \mathrm{ft}$. The annular space between the casing and borehole is open from 2,417 to 4,290 ft. A bridge plug was installed inside the casing at a depth of 4,309 ft (fig. 22A).
Well U-20n PS 1DD-H (3025 ft) was completed in May 1985, and includes casing from land surface to 4,495 ft with perforations from 2,665 to 2,995 ft and 4,202 to 4,285 ft. The annular space between the casing and borehole is open from 2,417 to 4,290 ft. A second bridge plug was installed inside the casing at a depth of 3,025 ft (fig. 22B).

Well U-20n PS 1DD-H (recompl) was completed in September 1998, and includes casing from land surface to 4,495 $\mathrm{ft}$ with perforations from 4,081 to 4,111 ft and 4,202 to 4,285 $\mathrm{ft}$. The annular space between the casing and borehole is open from 2,417 to 4,290 ft. The bridge plug at a depth of 3,025 ft was removed, and another bridge plug was installed inside the casing from 2,589 to 3,054 ft (fig. 22C). Based on lithology from nearby emplacement hole U-20n, the lithology at the saturated part of the open interval in all three wells consists of lava and flow breccia (fig. 22; Warren and others, 2003). Based on pumping and injection tests done at nearby borehole U-20a $2 \mathrm{WW}$, water in the three wells likely originates from the rhyolitic lava flows (Blankennagel and others, U.S. Geological Survey, written commun., 1964, p. 33).

U-20n PS 1DD-H originally was drilled as a slant re-entry hole to sample cavity rubble, then was recompleted to study radionuclide migration in the volcanic rocks at the Cheshire test site on Pahute Mesa (Desert Research Institute, written commun., no date, p. 1; Sawyer and others, 1999; Thompson, 1999). Since 1976, radionuclide migration studies at U-20n PS 1DD-H have been intermittent (Townsend and Grossman, 2000; p. 5-17). More than $9 \mathrm{Mgal}$ of water were withdrawn from the borehole from September 1983 to November 2005 (fig. 23A; appendix A).

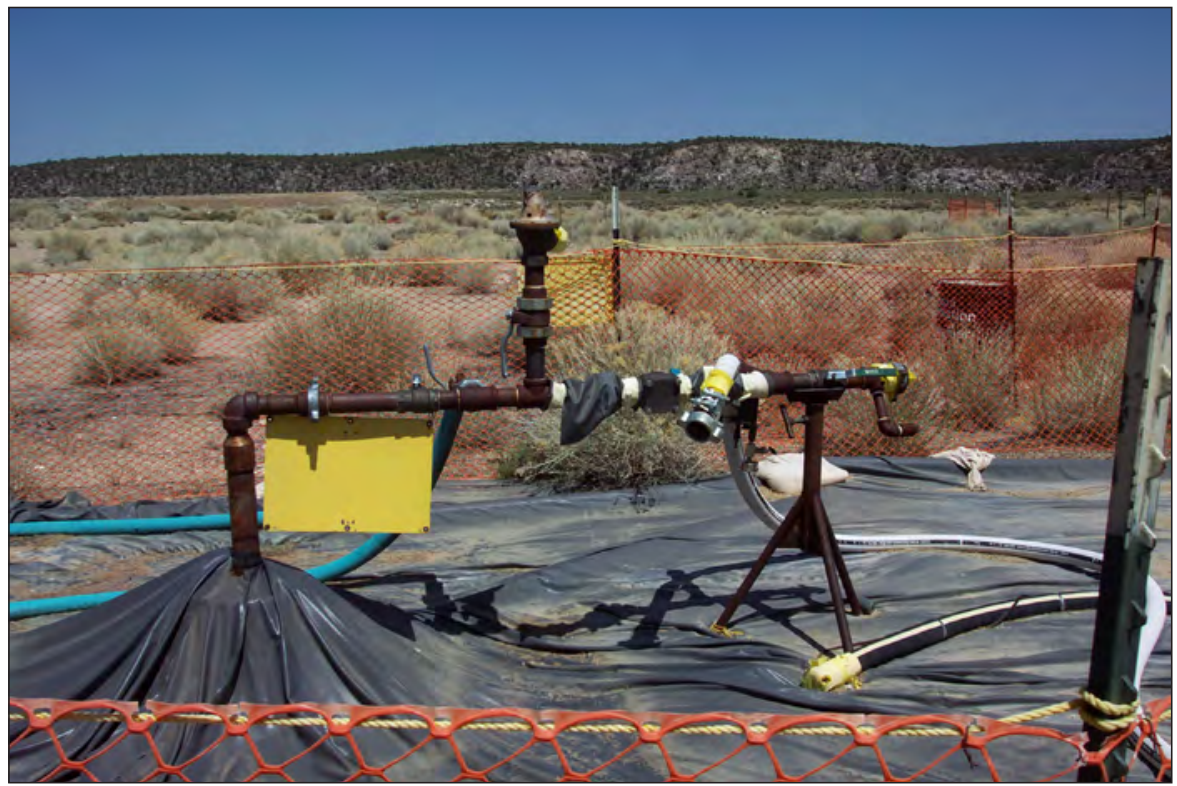

U -20n PS 1DD-H, April 2009. Photograph by Terry L. Miller, U.S. Geological Survey. 
Well name: $U$-20n PS 1DD-H (4309 ft)

USGS site identification No.: 371433116251301

Land-surface altitude: 6,468 feet above National Geodetic Vertical Datum of 1929 (NGVD29)

Latitude: $37^{\circ} 14^{\prime} 25^{\prime \prime}$

Longitude: $116^{\circ} 25^{\prime} 24^{\prime \prime}$

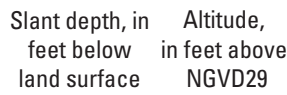

Lithology description (from

Warren and others, 2003)

Well-construction diagram (from Fenix \&

land surface NGVD29

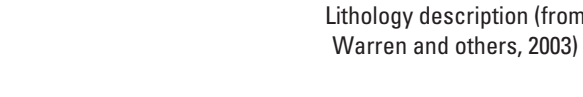

Scisson, Inc. written commun., 1976, 1989)
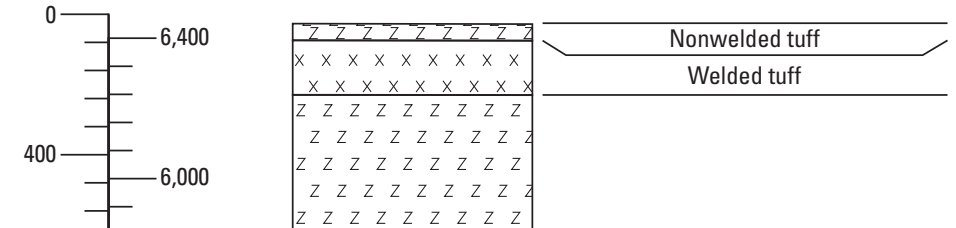

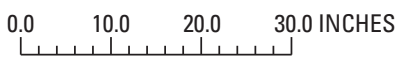

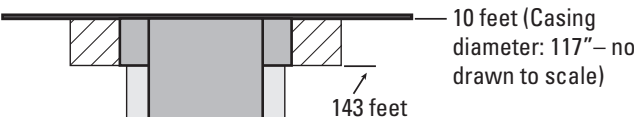

$z z z z z z z z$

$z \quad z \quad z \quad z \quad z \quad z \quad z \quad z$

Nonwelded tuff

$\begin{array}{llllllll}z & z & z & z & z & z & z & z\end{array}$

$\begin{array}{llllllllll}z & z & z & z & z & z & z & z & z\end{array}$

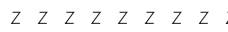

$z \quad z \quad z \quad z \quad z \quad z \quad z \quad z$

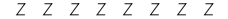

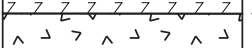

$\vec{\lambda}>\wedge \vec{r}>\wedge \vec{r}$
$\ulcorner\uparrow<\uparrow$

$\vec{A}<>>L>>C$

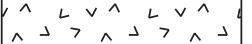

$\Rightarrow r \uparrow<, r \uparrow<$,

$\wedge<L>_{V} \wedge<{ }_{L}>_{V} \wedge$

\begin{tabular}{|c|c|}
\hline 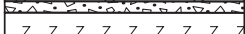 & Flow breccia \\
\hline$z z z z z z z z z$ & Nonwelded tuff \\
\hline
\end{tabular}

Lava

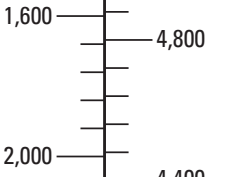

$\checkmark r<, r \uparrow<, r$

$\lambda^{2}>>\wedge><<$

$\wedge \vec{\sim}>\wedge \vec{\sim} \wedge \vec{\sim}$

$\vec{\sim}\ulcorner<, r \uparrow<, r$

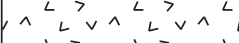

$\wedge \vec{\sim} \wedge \overrightarrow{\neg \wedge} \vec{\sim}$

$\checkmark r \uparrow<, r 1<, r$

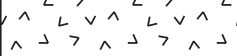

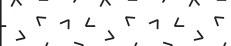

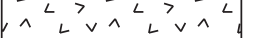

Lava

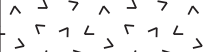

$\wedge<><>>$

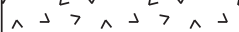

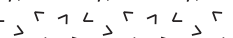

$\vec{A}<><>>$

$\wedge \neg>\wedge \wedge \neg \wedge$

$\checkmark r \neg<, r \uparrow<>r$.

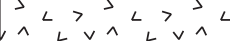

$\wedge\lrcorner>\wedge\lrcorner>\wedge$

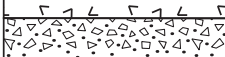

$\because \Delta \Delta \Delta \Delta \Delta \Delta$

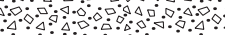

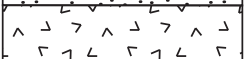

$\left.\left.{ }_{L} \backslash\right\rangle>L\right\rangle>$

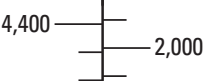

$\wedge, \vee \wedge, \vee \wedge$

$\frac{\text { Flow breccia }}{\text { Lava }}$

EXPLANATION

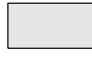

Open borehole or annulus

Casing
Slotted or perforated casing

Cement, thickness of two lowermost intervals estimated
Bridge plug

Packer

Figure 22. Borehole lithology and well construction for wells U-20n PS 1DD-H (4309 ft), U-20n PS 1DD-H (3025 ft), and U-20n PS $1 D D-H$ (recompl), Area 20, Nevada National Security Site, Nye County, Nevada. 
Well name: U-20n PS 1DD-H (3025 ft)

USGS site identification No.: 371425116252401

Land-surface altitude: 6,468 feet above National Geodetic Vertical Datum of 1929 (NGVD29)

Latitude: $37^{\circ} 14^{\prime} 25^{\prime \prime}$

Longitude: $116^{\circ} 25^{\prime} 24^{\prime \prime}$

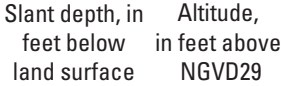

surface NGD29
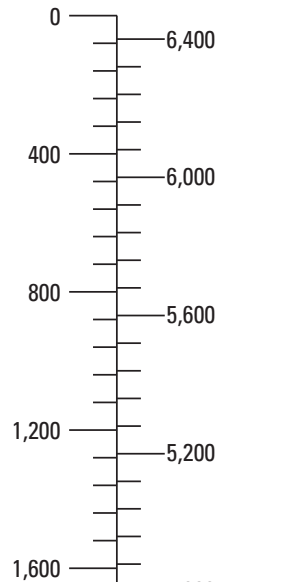

\begin{tabular}{|c|}
\hline$z z z z z z z z$ \\
\hline$x \times x \times x \times x \times x$ \\
$x \times x \times x \times x \times$ \\
\hline$z z z z z z z z$ \\
$z z z z z z z z z$ \\
$z z z z z z z z$ \\
$z z z z z z z z z$
\end{tabular}

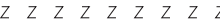

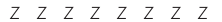

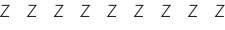

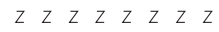

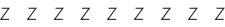

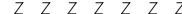

$\begin{array}{lllllllll}z & z & z & z & z & z & z & z & z\end{array}$

$\ulcorner\neg<, r \uparrow<, r]$

$\wedge>\wedge<>\wedge$

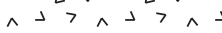

$r \neg<, r \uparrow L, r$

$\wedge<>\wedge<>\wedge<$

$\wedge \neg>\wedge \rightarrow$

$\begin{array}{ccc}r q z & 1, & \\ z z z z z z z z z \\ z z z z z z z z\end{array}$

$\wedge\llcorner\vee \vee \wedge\llcorner\vee \vee \wedge$

$\wedge \vec{\sim}>\wedge \vec{\nu}>\overrightarrow{ }$

$>\ulcorner\uparrow<, r \uparrow<, r$

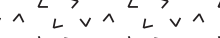

$\wedge\lrcorner>\wedge \neg>\wedge J$

$>\ulcorner\uparrow<, r \uparrow L, r$

$\wedge{ }^{L}{ }^{\prime} \vee \wedge{ }^{L}{ }^{\prime} \vee \wedge^{L}$

$\wedge \neg \wedge \vec{r} \wedge \hat{\ulcorner}$

$\vec{L}_{L}>\vec{C}_{L}>{ }_{L}$

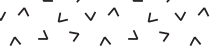

$r \uparrow<, r \uparrow<, r$

$\vec{A}<>\vec{\lambda}<>\vec{\gamma}<$

$\wedge\lrcorner \neg \wedge \Delta \neg>\wedge \wedge$

$r \uparrow<, r \uparrow<, r$

$\vec{A}<>\vec{\wedge}<><$

$\wedge\lrcorner>\wedge \Delta>\wedge\lrcorner$

$\checkmark \neg<, r \uparrow<, r$

$\wedge$ L $L \wedge<\vee \wedge$

$\wedge\lrcorner>\wedge\lrcorner>\wedge\lrcorner$

, $r 1<, r 1<, r$

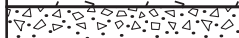

$\because \Delta \Delta \Delta \quad \because \Delta \Delta$

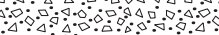

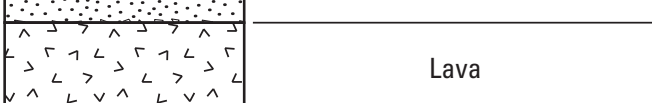

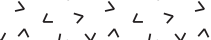

Nonwelded tuff
Well-construction diagram (from Fenix \& Scisson, Inc., written commun., 1976, 1989)

$\begin{array}{lll}0.0 & 10.0 \quad 20.0 \quad 30.0 \text { INCHES }\end{array}$

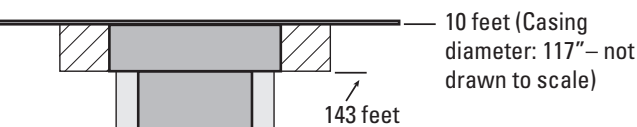

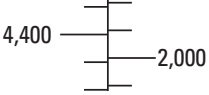

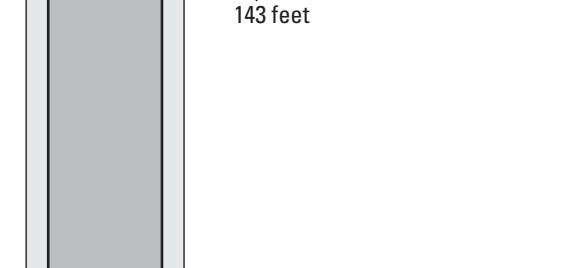

EXPLANATION
B
Open borehole or annulus
Slotted or perforated casing
Cement, thickness of two lowermost intervals estimated
Bridge Plug
Average water level
Casing

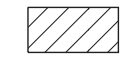
Packer

Figure 22.-Continued 
Well name: U-20n PS 1DD-H (recompl)

USGS site identification No.: 371425116252403

Land-surface altitude: 6,468 feet above National Geodetic Vertical Datum of 1929 (NGVD29)

Latitude: $37^{\circ} 14^{\prime} 25^{\prime \prime}$

Longitude: $116^{\circ} 25^{\prime} 24^{\prime \prime}$

Slant depth, in Altitude,
feet below in feet abov
land surface NGVD29

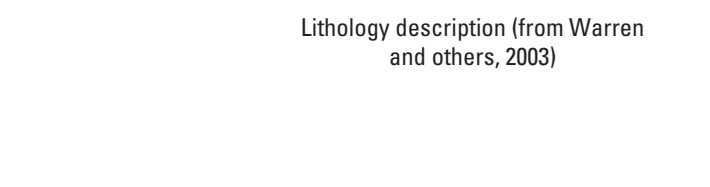

Well-construction diagram (from Fenix \& Scisson, Inc., written commun., 1976, 1989; Thompson, 1999)
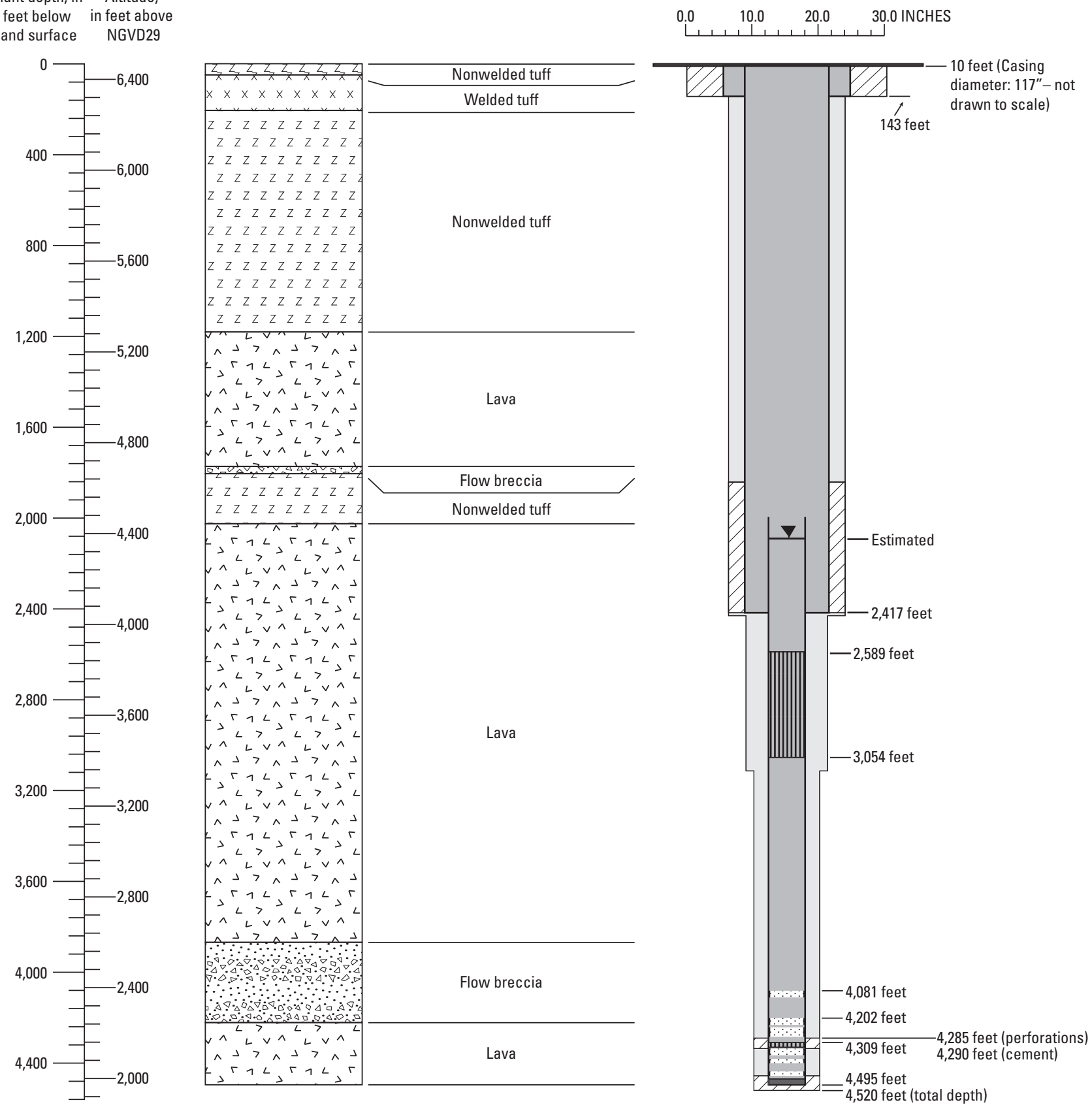

\begin{tabular}{|c|c|}
\hline 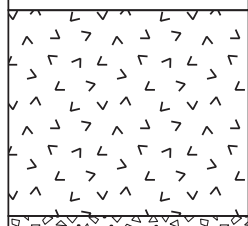 & Lava \\
\hline$z z z z z z z z z$ & Flow breccia \\
\hline$z z z z z z z z z$ & Nonwelded tuff \\
\hline
\end{tabular}

\begin{tabular}{|c|c|}
\hline 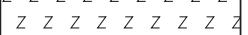 & Nonwelded tuff \\
\hline 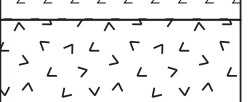 & IVorinvelued tur \\
\hline
\end{tabular}

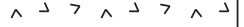

$\Rightarrow\ulcorner\neg L,\ulcorner\neg L, r$.

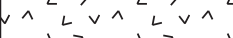

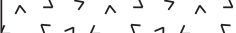

$\Rightarrow r T<, r T<, r$

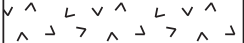

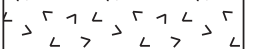

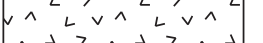

Lava

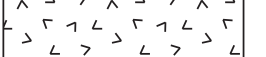

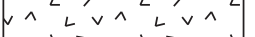

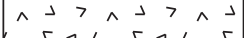

$\rightarrow r T<, r T<, r$.

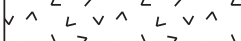

$\wedge \vec{\nu} \wedge \vec{\sim} \wedge \wedge \vec{\sim}$

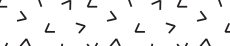

\begin{tabular}{|c|c|}
\hline & Flow breccia \\
\hline 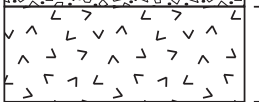 & Lava \\
\hline
\end{tabular}

EXPLANATION

Open borehole or annulus

Casing

C

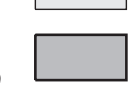

Casing

Figure 22.-Continued
Slotted or perforated casing

Cement, thickness of two lowermost intervals estimated
Bridge Plug

Estimated water level

Packer 
Withdrawal data are not available prior to August 1983. Well U-20n PS 1DD-H (4309 ft) was pumped sporadically from September 1983 to May 1985 for a total of $3.5 \mathrm{Mgal}$ of water withdrawn. Well U-20n PS 1DD-H (3025 ft) was pumped from May to November 1985 and in July 1998 for a total of about 5.8 Mgal of water withdrawn. Well $U$-20n PS $1 D D-H$ (recompl) was pumped in September 1998, October 1999, and November 2005 for a total of about $0.11 \mathrm{Mgal}$ of water withdrawn (Thompson, 1999, p. 8; Townsend and Grossman, 2000 , p. 5-18). The well also was sampled in 2003, but the amount of water withdrawn is unknown (Wills, 2004, p. 3-15).
Periodic water-level measurements were made in U-20n PS 1DD-H from 1983 to 1998 (fig. 23B). The water levels range from about 2,041 to 2,043 ft below land surface in well U-20n PS 1DD-H (4309 ft), and 2,038 to 2,053 ft below land surface in well $U$-20n PS $1 D D-H$ (3025 ft). No known water levels were measured in well $U$-20n PS $1 D D-H$ (recompl). Water levels from 1985 to 1996 show a declining trend that was correlated with pumping in nearby well $U$-20 WW (cased) (Fenelon, 2000, p. 26).
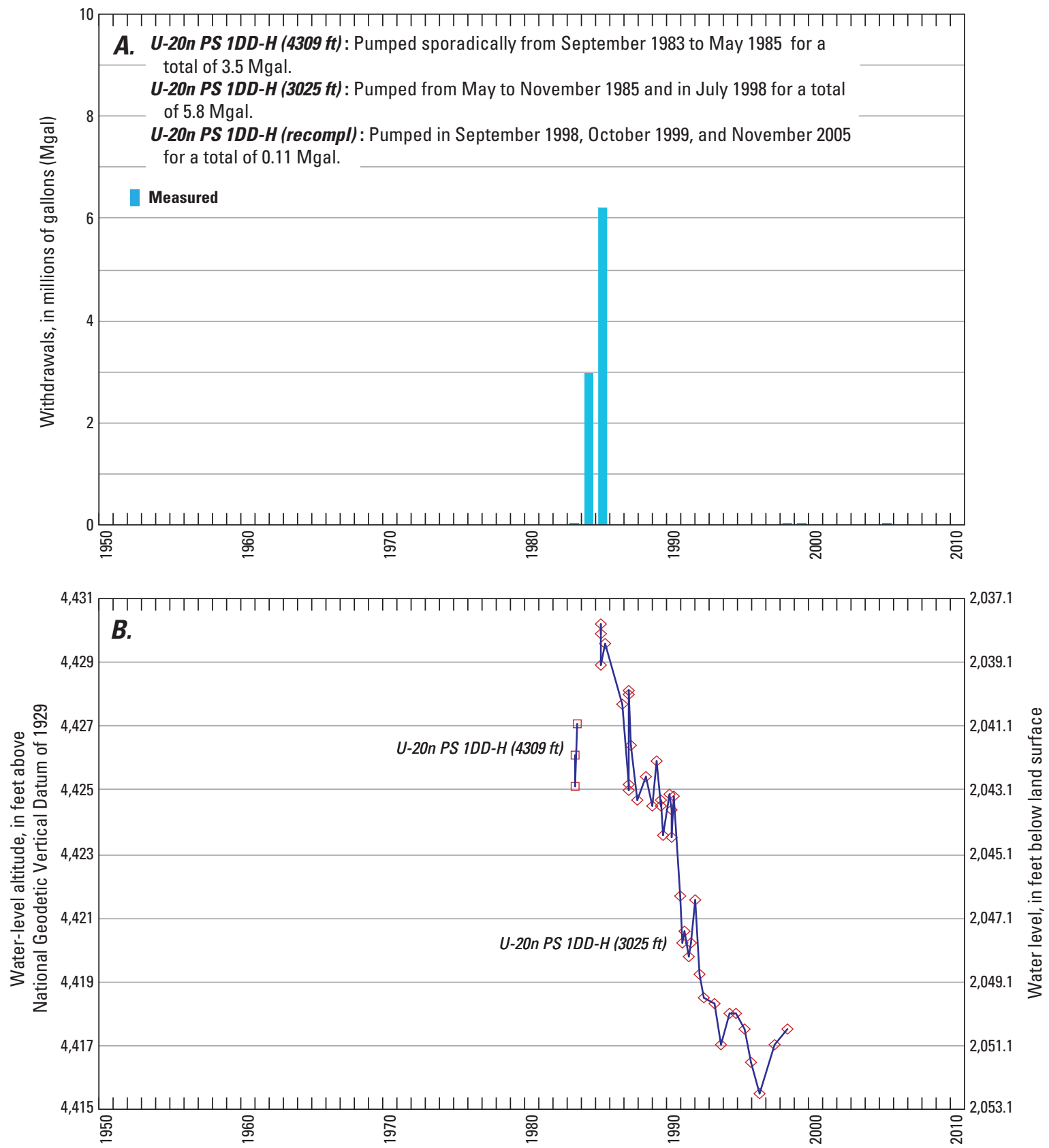

Figure 23. Annual groundwater withdrawals and water levels for wells U-20n PS 1DD-H (4309 ft), U-20n PS 1DD-H (3025 ft), and U-20n PS 1DD-H (recompl), Area 20, Nevada National Security Site, Nye County, Nevada, 1983-2008. 
UE-1r WW.-UE-1r WW is in Yucca Flat in Area 1 of the NNSS (fig. 1; table 1; UE-1r WW photograph). Construction information for the borehole was compiled from Fenix \& Scisson, Inc., hole history data (written commun., 1984). The borehole was drilled and completed to a depth of 4,182 ft below land surface in January 1984 using the conventional circulation method with air foam. Borehole diameter ranges from $36 \mathrm{in}$. at land surface to $12.25 \mathrm{in}$. at the bottom of the hole.

Borehole UE-1r WW has a single completion interval, well $U E-1 r W W$, which includes casing to a depth of 2,319 ft, and an open borehole to 4,182 ft (fig. 24). The lithology at the saturated part of the open interval consists mostly of nonwelded and welded tuffs, with some Paleozoic carbonate rocks (fig. 24; Warren and others, 2003; Wood, 2007). Little information exists on water-producing zones in the open interval; the carbonate rocks from 3,660 to 3,790 ft likely contribute water to this well. However, an obstruction is located at a depth of 3,145 ft below land surface (Fenix \& Scisson, Inc., written commun., 1984), and it is unknown if or how it may affect water coming into the well.

UE-1r WW primarily was used as a water supply for construction (Wood and Reiner, 1996, p. 9). Pumping in well UE-1r WW began in August 1984 and continued through October 1988 when the well was shut down (M.E. Ashbaugh, Reynolds Electrical \& Engineering Co., Inc., written commun., 1988). More than 23 Mgal of water were withdrawn from the well during this time (ig. 25A; appendix A).

One water-level measurement obtained from a geophysical log for well $U E-1 r W W$ is shown in figure $25 B$. The depth of this measurement is $1,626 \mathrm{ft}$ below land surface. This measurement is consistent with water-level altitudes from nearby wells.

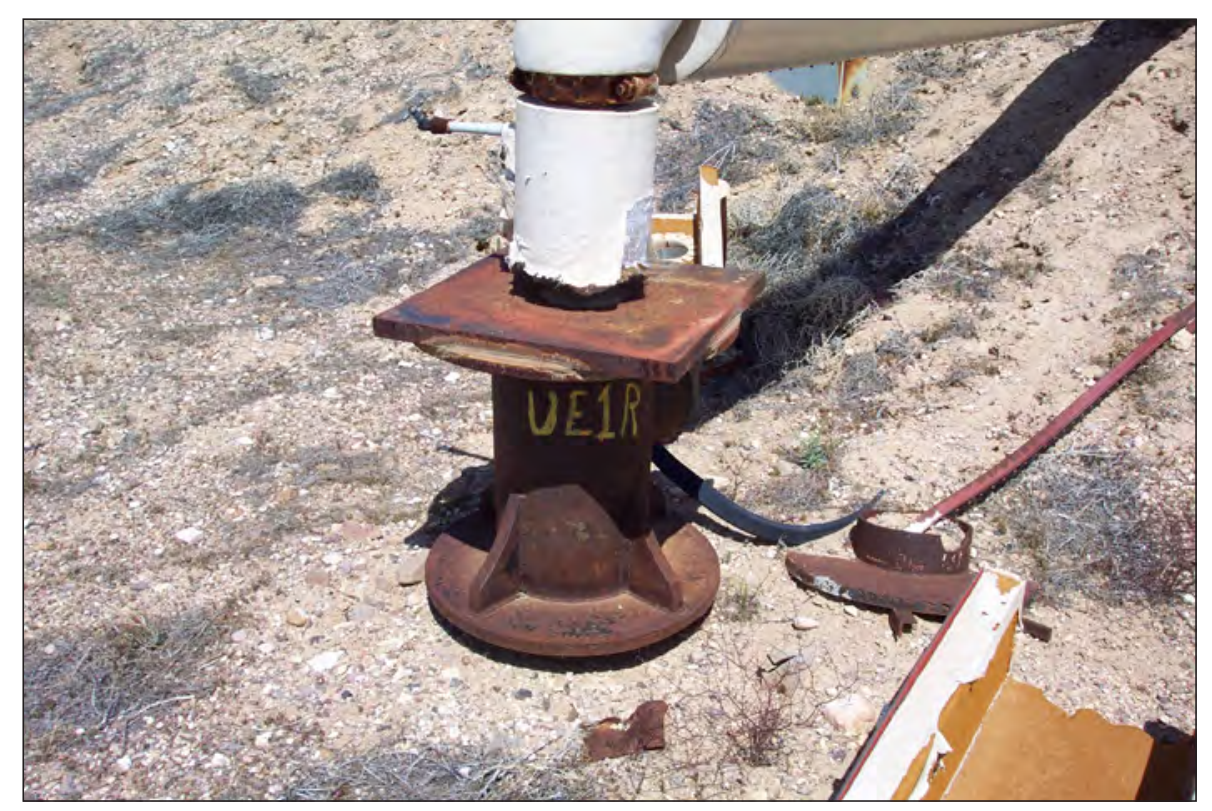

UE- 1r WW, April 2009. Photograph by Terry L. Miller, U.S. Geological Survey. 


\section{Well name: UE-1r WW}

USGS site identification No.: 370142116033301

Land-surface altitude: 4,042 feet above National Geodetic Vertical Datum of 1929 (NGVD29)

Latitude:-

Longitude:-
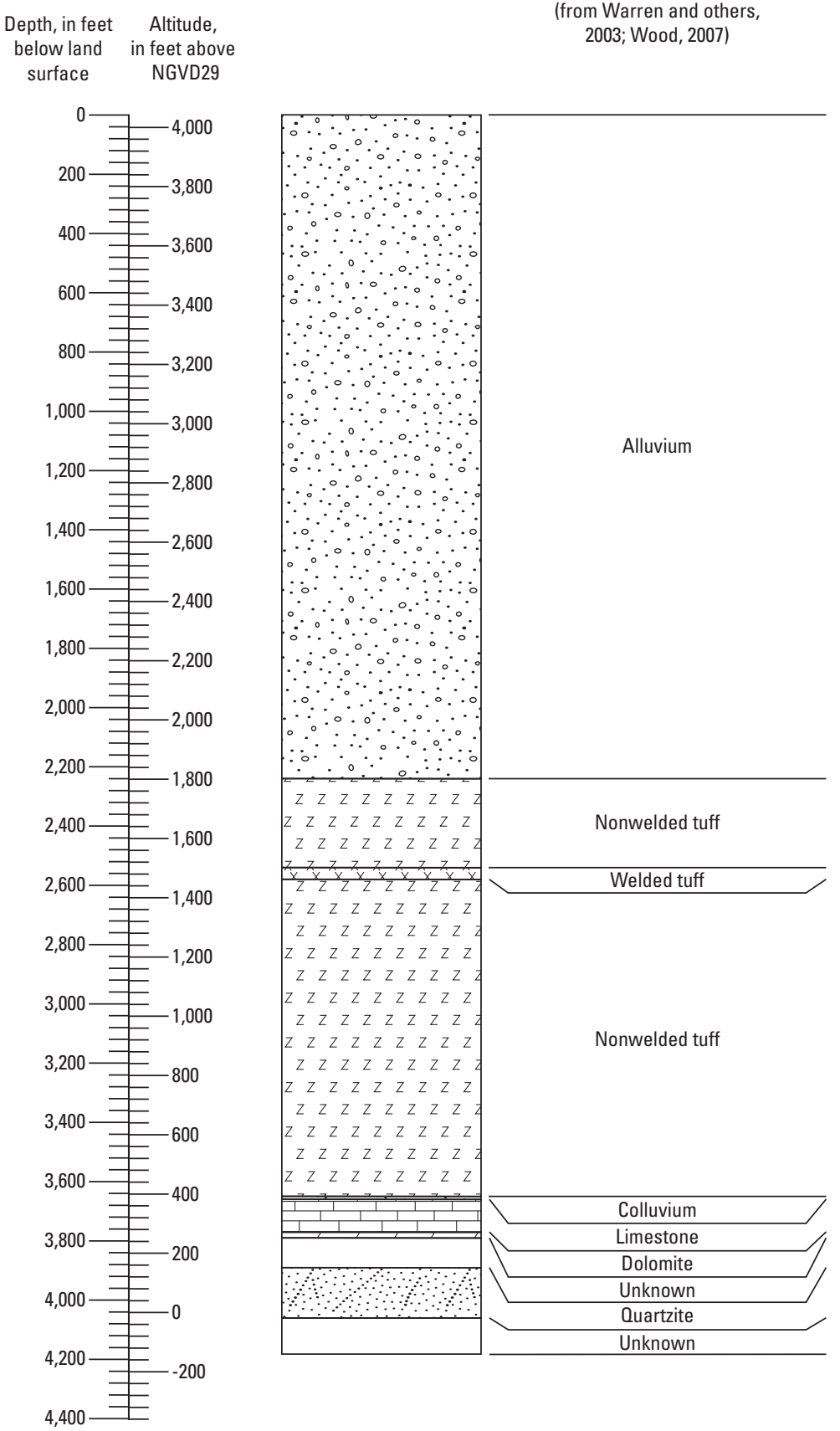

$\because \because \because \cdots$

$\therefore \because \cdots$

$\therefore \cdots$

$\because \because \because 00$

$\therefore \because \cdots$

$\because \because \cdots$

$\because \because \because \cdots$

$\frac{0}{z z z z z z z z}$

$z z z z z z z z z$

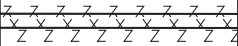

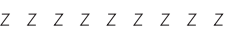

$\begin{array}{llllllllll} & z & z & z & z & z & z\end{array}$

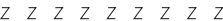

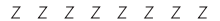

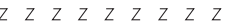

$z z z z z \quad z \quad z$

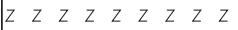

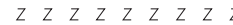

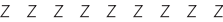

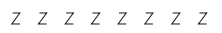

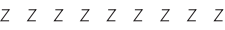

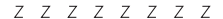

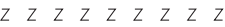

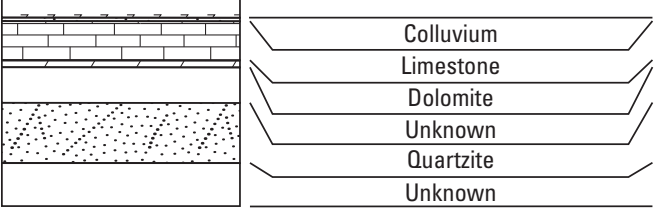

Nonwelded tuff

2003; Wood, 2007)

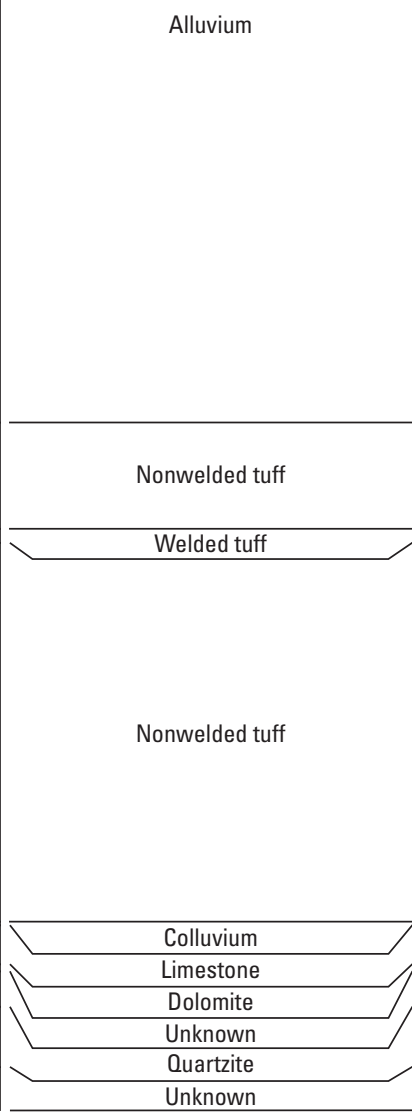

\section{EXPLANATION}
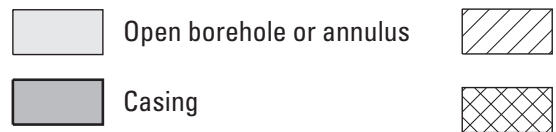

Cement, exact thickness at bottom of casing unknown

Obstruction $\because \because 0$ Warren and others

Well-construction diagram (from Fenix \& Scisson, Inc., written commun., 1984)
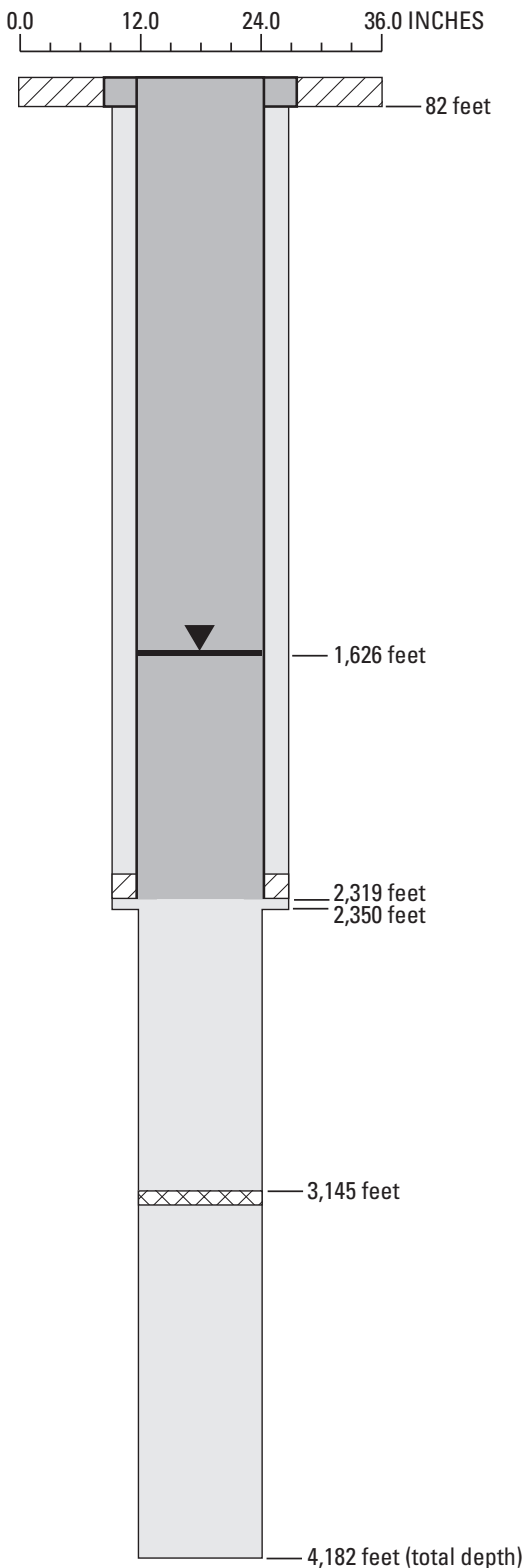

4,182 feet (total depth)

Figure 24. Borehole lithology and well construction for well UE-1r WW, Area 1, Nevada National Security Site, Nye County, Nevada. 

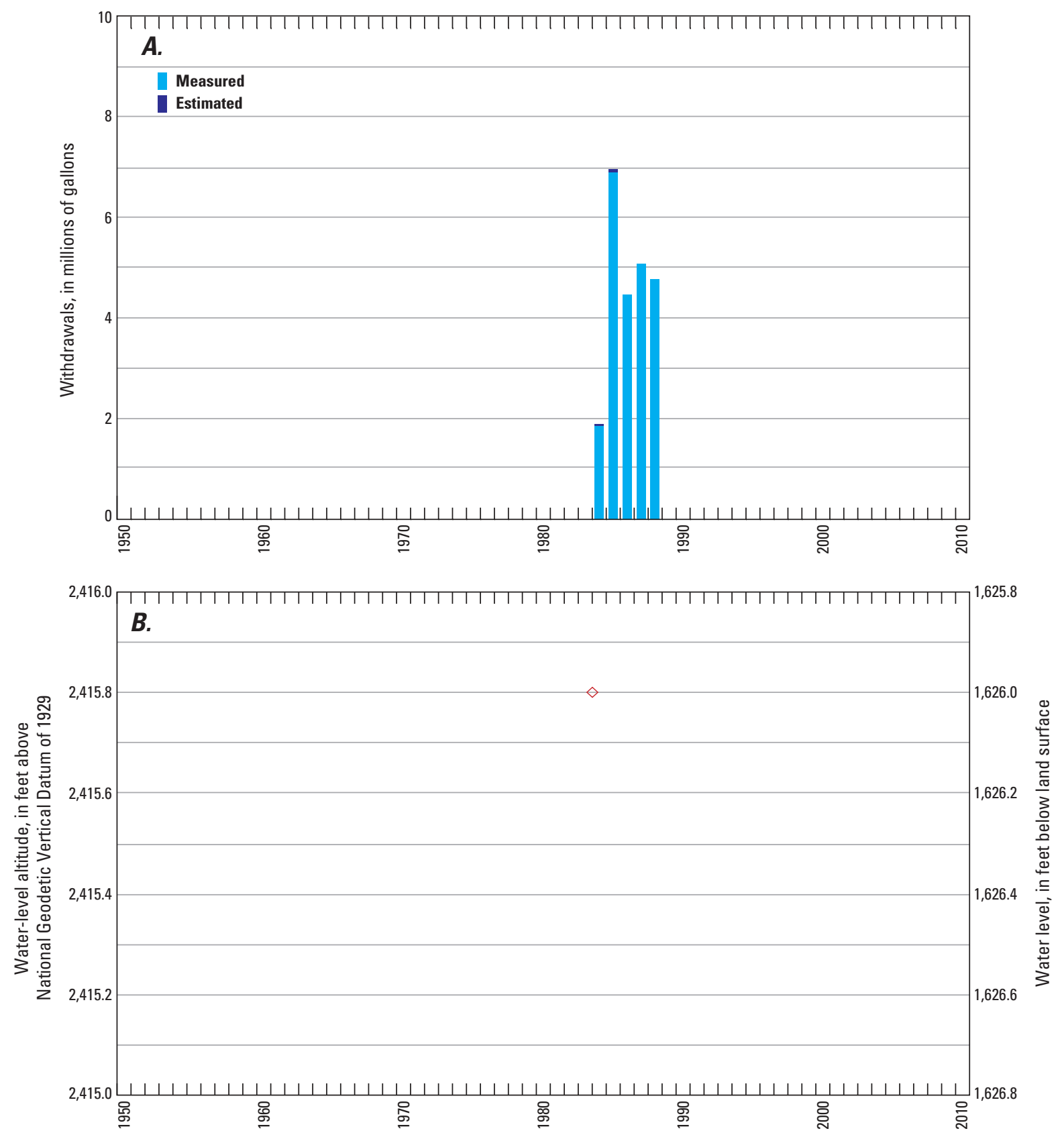

Figure 25. Annual groundwater withdrawals and water levels for well UE-1r WW, Area 1, Nevada National Security Site, Nye County, Nevada, 1984-88. 
UE-2ce.-UE-2ce is on the northwestern edge of Yucca Flat in Area 2 of the NNSS (fig. 1; table 1; UE-2ce photograph). Construction information for the borehole was compiled from Fenix \& Scisson, Inc., hole history data (written commun., 1977) and daily rig operations (written commun., 1989). The borehole was drilled and completed to a depth of 1,650 ft below land surface in January 1977 using the conventional circulation method with air foam. Borehole diameter ranges from $26 \mathrm{in}$. at land surface to $12.25 \mathrm{in}$. at the bottom of the hole.

Borehole UE-2ce has a single completion interval, well $U E-2 c e$, which includes casing to a depth of 1,624 ft with a slotted interval from 1,384 to 1,624 ft. The annular space between the casing and borehole is open below 1,378 ft (fig. 26). A 2.88 in. diameter and 2.38 in. diameter tubing were installed to depths of 1,504 and 1,505 ft, respectively, in the well. The bottom $60 \mathrm{ft}$ of each tubing is perforated. The lithology at the saturated part of the open interval in the well consists of dolomite (fig. 26; Wood, 2007). The well is cased so that only the carbonate rocks contribute water to the well (Thompson, 1985, p. 26).
UE-2ce was drilled to determine hydrologic, geologic, and geophysical characteristics of the units penetrated by the borehole, which were then extrapolated to the nearby nuclear test site Nash (Pawloski, 1982, p. 1, 15). After completion, well UE-2ce was used to study radionuclide migration from the Nash event (Buddemeier and Isherwood, 1985, p. 16-22). In support of this study, intermittent pumping and sampling occurred in the well from 1977 to 1984 (Buddemeier and Isherwood, 1985, p.18). During this time, more than $11 \mathrm{Mgal}$ of water were withdrawn from the well (fig. 27A; appendix A). An additional $0.035 \mathrm{Mgal}$ were withdrawn during more recent sampling in 2008 (Russell Shelton, National Security Technologies, LLC, written commun., 2008).

Periodic water-level measurements made in well UE-2ce since 1977 are shown in figure 27B. The water levels range from about 1,398 to 1,478 ft below land surface. Measurements in this well have been affected by localized conditions including pumping and proximity to the nuclear test Nash, which was detonated in 1967 (Fenelon, 2005, p. 47). Pumping of the well stopped in 1984, and water levels show a rising trend from 1984 to 1994 . However, this rising trend may have masked an overall declining trend which likely was caused by the Nash test.

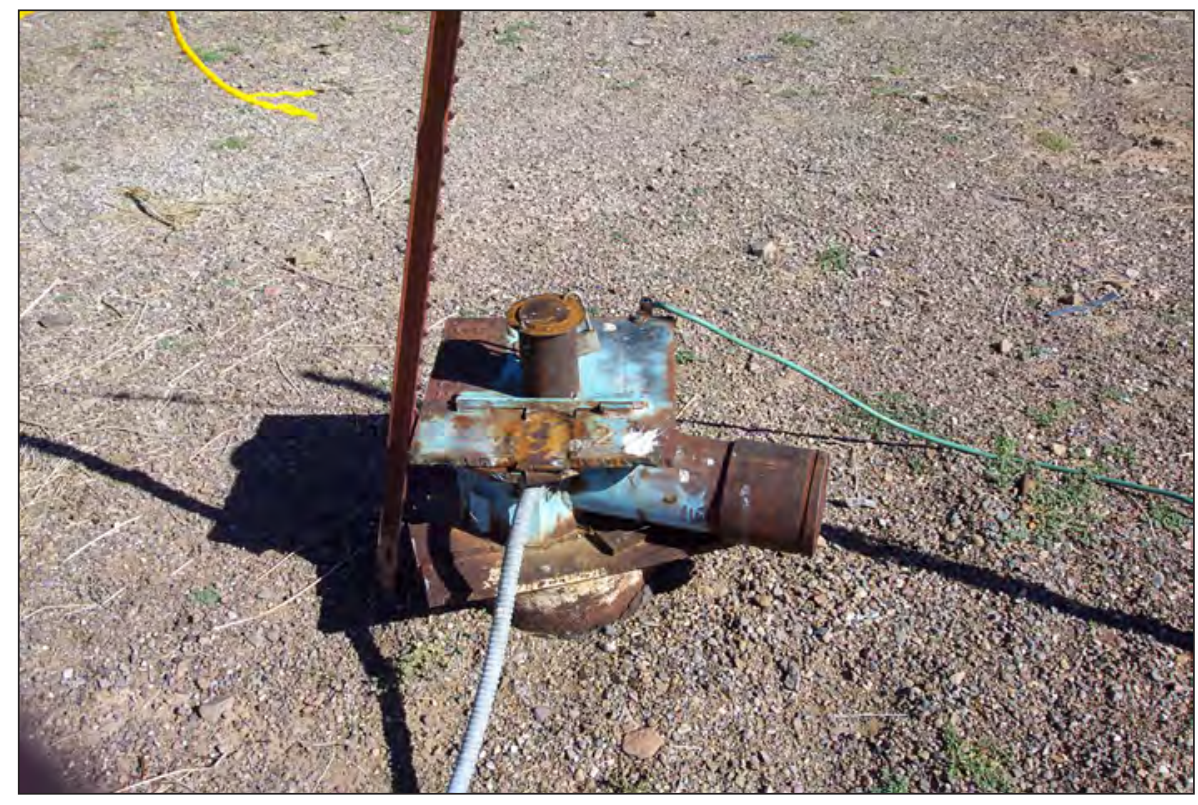

UE- 2ce, August 2008. Photograph by Terry L. Miller, U.S. Geological Survey. 
Well name: UE-2ce

USGS site identification No.: 370831116080701

Land-surface altitude: 4,765 feet above National Geodetic Vertical Datum of 1929 (NGVD29)

Latitude: $37^{\circ} 08^{\prime} 31^{\prime \prime}$

Longitude: $116^{\circ} 08^{\prime} 07^{\prime \prime}$
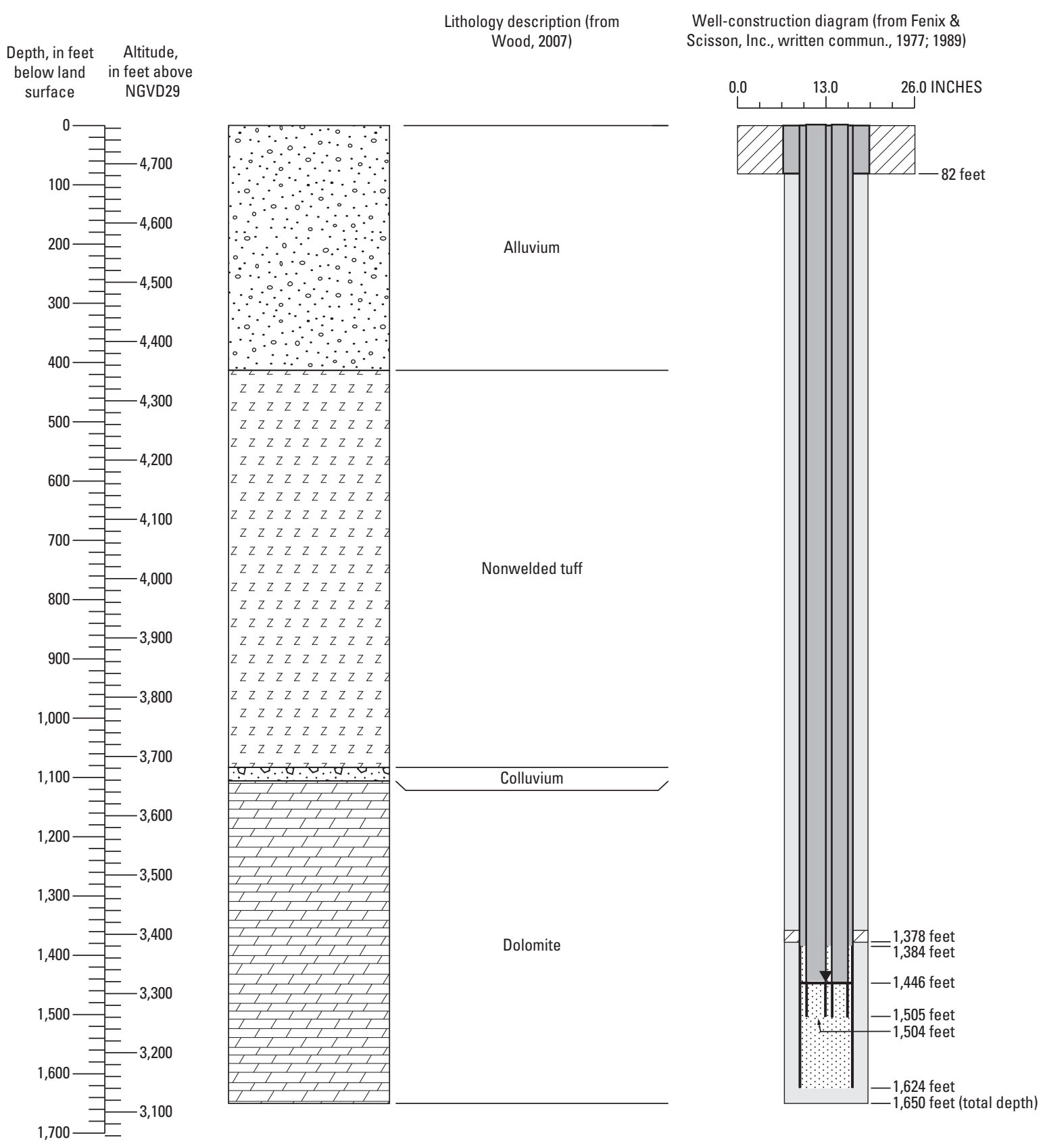

\section{EXPLANATION}

Slotted or perforated casing $\quad \nabla \quad$ Average water level

Cement

Figure 26. Borehole lithology and well construction for well UE-2ce, Area 2, Nevada National Security Site, Nye County, Nevada. 

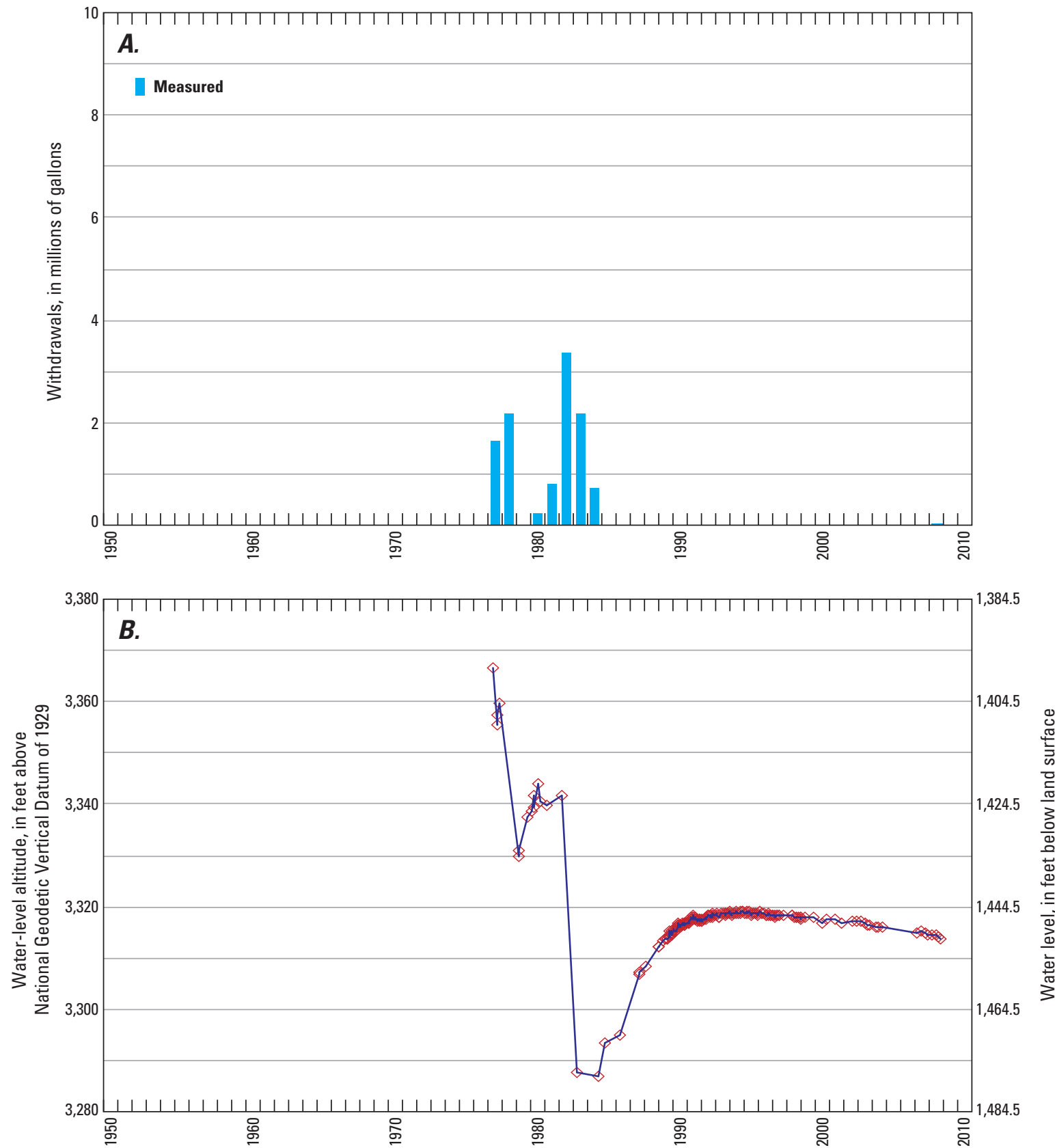

Figure 27. Annual groundwater withdrawals and water levels for well UE-2ce, Area 2, Nevada National Security Site, Nye County, Nevada, 1977-2008. 
UE-5c WW.-UE-5c WW is in Frenchman Flat in Area 5 of the NNSS (fig. 1; table 1; UE-5c WW photograph). Construction information for the borehole was compiled from Fenix \& Scisson, Inc., hole history data (written commun., 1965) and daily drilling report (written commun., 1966), and Thordarson and others, (1967). The borehole was drilled to a depth of 2,682 ft below land surface in November 1964 using the air-rotary method. The borehole was completed as a water-supply well in April 1966 when the casing was perforated (Fenix \& Scisson, Inc., written commun., 1966) to open the hole to more permeable alluvium (R.A. Young, U.S. Geological Survey, written commun., 1966). Borehole diameter ranges from $26 \mathrm{in}$. at land surface to $9.88 \mathrm{in}$. at the bottom of the hole.

Borehole UE-5c WW has a single completion interval, well $U E-5 c W W$, which includes casing to a depth of 1,682 ft, and an open borehole to 2,682 ft (fig. 28). The casing is perforated from 1,100 to $1,300 \mathrm{ft}$, and the annular space between the casing and borehole is open from 77 to $1,300 \mathrm{ft}$. The lithology at the saturated part of the open interval consists of alluvium, volcanic breccia, and welded tuff (fig. 28; Wood, 2007). Most of the water in the well likely originates from the alluvium with minor amounts from the tuff (Gillespie and others, 1996b, p. 20).

UE-5c WW was drilled as an exploratory hole (R.A. Young, U.S. Geological Survey, written commun., 1965, p. 9), and later was used for water supply on the NNSS (G.T. Bruesch, Fenix \& Scisson, Inc., written commun., 1972). Pumping in well UE-5c WW began in 1967. The well also has been monitored as part of DOE's hydrologic monitoring network since 1973 (Russell, 1989; Bechtel Nevada, 2003; U.S. Department of Energy, 2008, p. 7-6). Groundwater withdrawals from the well from 1967 to 2006 were estimated to be more than $153 \mathrm{Mgal}$ (ig. 29A; appendix A); since about 1997, pumping in the well has been sporadic.

Periodic water-level measurements made in well UE-5C $W W$ from 1971 to 1987 are shown in figure 29B. The water levels range from about 805 to $810 \mathrm{ft}$ below land surface. Water levels show a declining trend from pumping in the well.

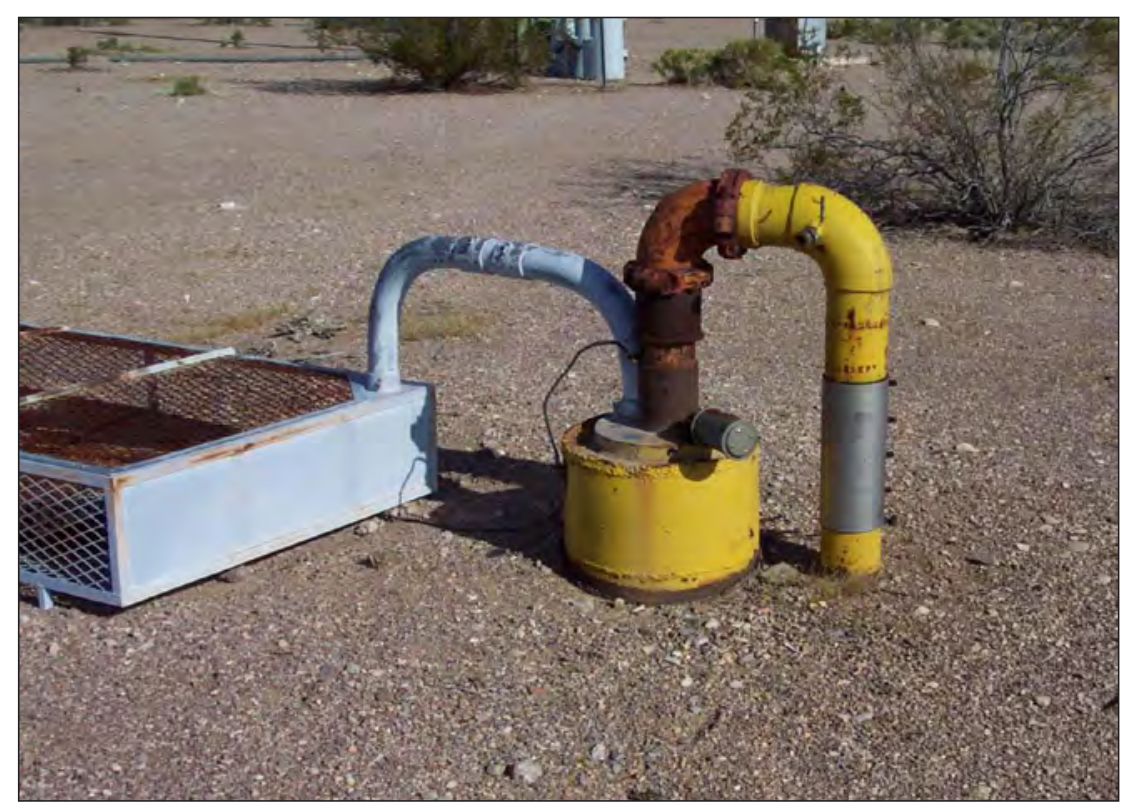

UE- 5c WW, April 2009. Photograph by Terry L. Miller, U.S. Geological Survey. 
Well name: UE-5c WW

USGS site identification No: 365011115584702

Land-surface altitude: 3,216 feet above National Geodetic Vertical Datum of 1929 (NGVD29) Latitude: -

Longitude:-
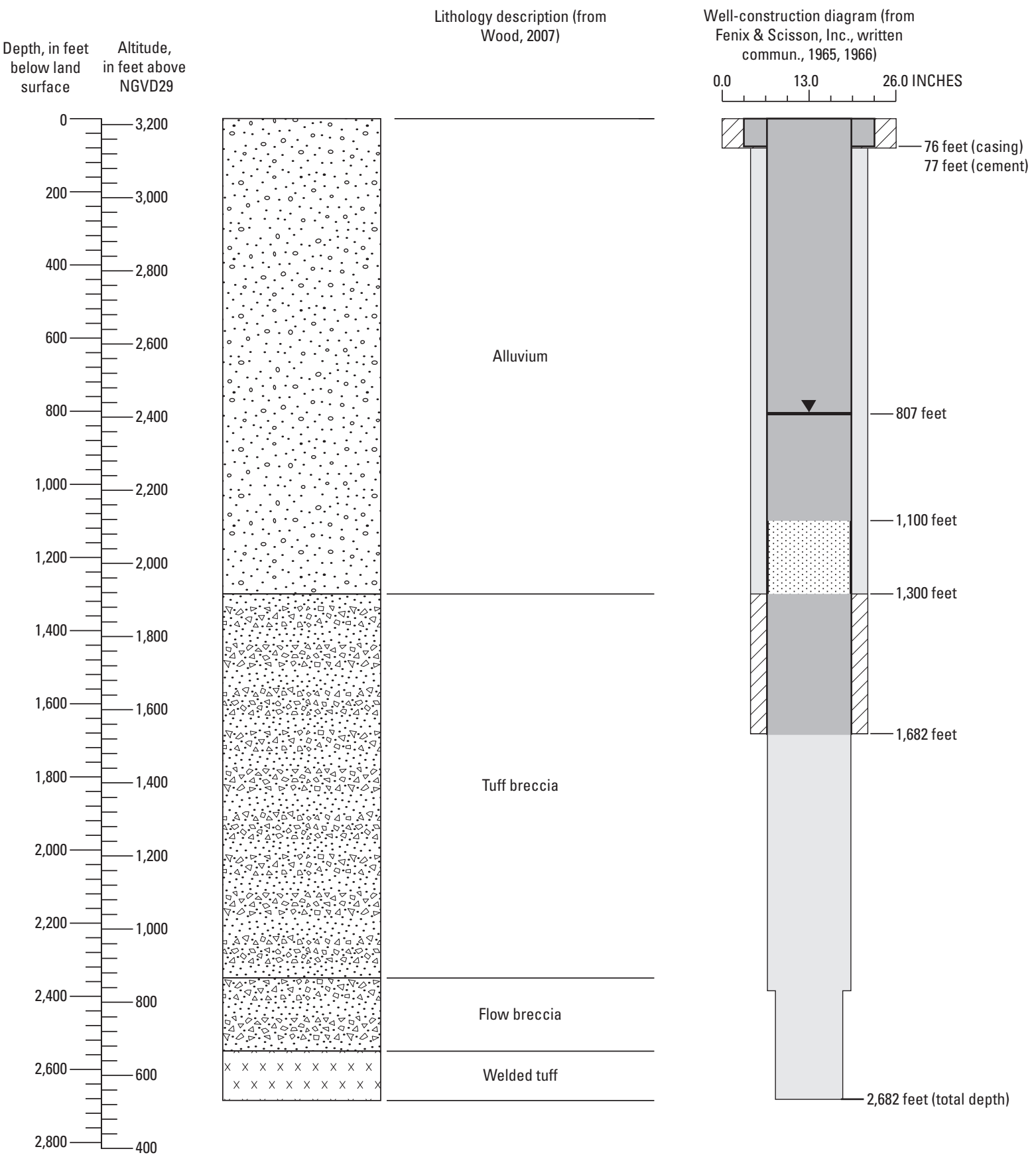

\section{EXPLANATION}

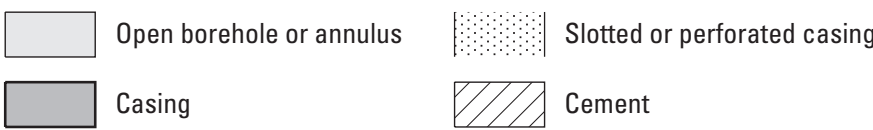

$\boldsymbol{\nabla}$ Average water level

Figure 28. Borehole lithology and well construction for well UE-5c WW, Area 5, Nevada National Security Site, Nye County, Nevada. 

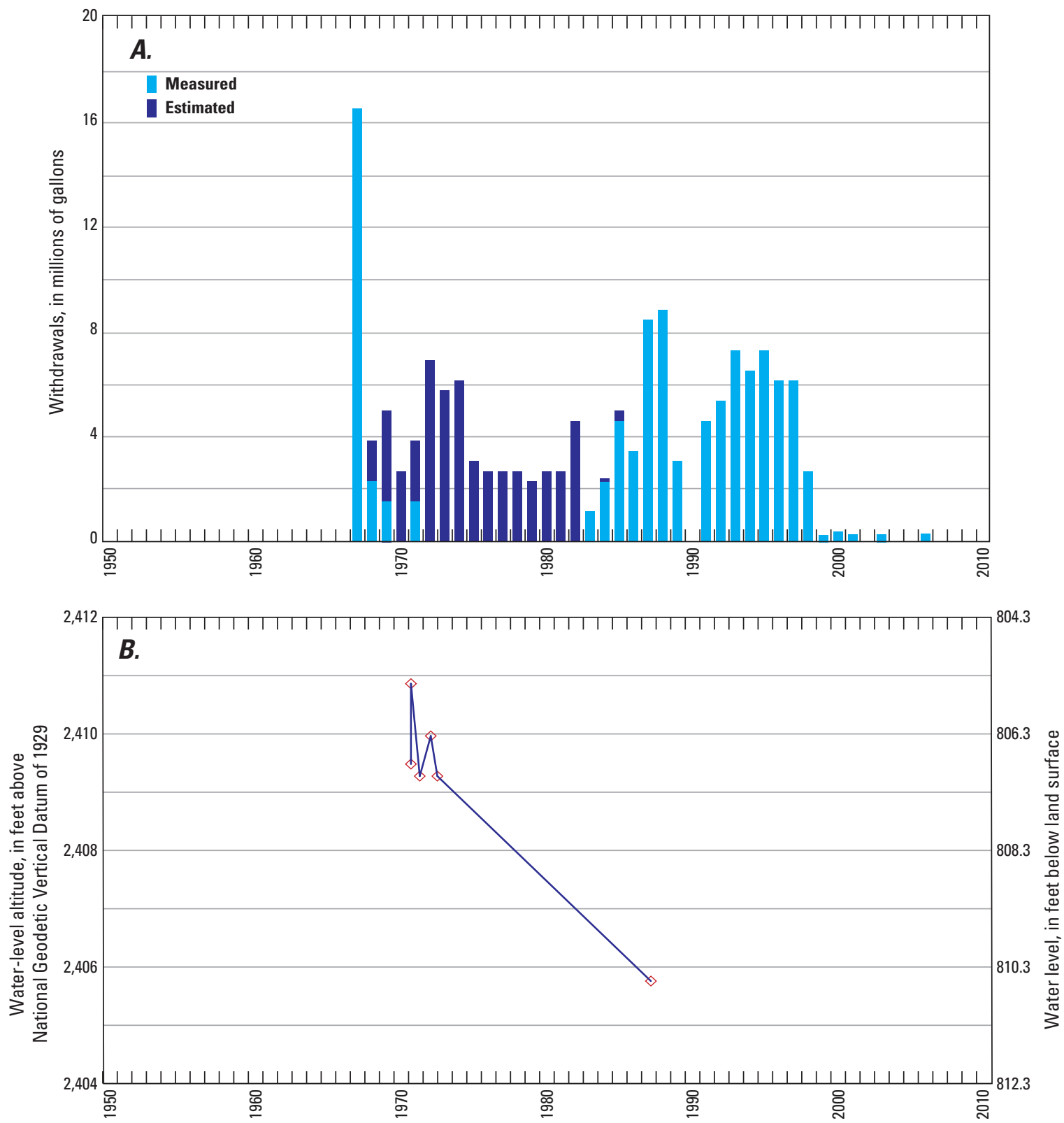

Figure 29. Annual groundwater withdrawals and water levels for well UE-5c WW, Area 5, Nevada National Security Site, Nye County, Nevada, 1966-2008. 
UE-15d WW.-UE-15d WW is at the north end of Yucca Flat in Area 15 of the NNSS (fig. 1; table 1; UE-15d WW photograph). Construction information for the borehole was compiled from Fenix \& Scisson, Inc., hole history data (written commun., 1965), and Thordarson and others (1967). The borehole was drilled to a depth of 6,001 ft below land surface in March 1962 using the standard-rotary method, and then completed as a water-supply well in April 1962. The original borehole deviated from vertical during drilling; at a hole depth of 6,001 ft, the true vertical depth is $5,940.5 \mathrm{ft}$. Measured (slant) depths are used hereafter when referring to UE-15d WW. Water levels were not corrected for borehole deviation. Borehole diameter ranges from 15 in. at land surface to $6.25 \mathrm{in}$. at the bottom of the hole.

Borehole UE-15d WW has two completion intervals, well UE-15d WW (1735-6001 ft) and well UE-15d WW (cased). Well UE-15d WW (1735-6001 ft) represents the borehole as it was completed in March 1962. This completion is cased to a depth of 1,735 ft with an open borehole to 6,001 ft (fig. 30A).

Well UE-15d WW (cased) was constructed on April 17, 1962, when a liner was installed in the borehole. The liner extends to a depth of $5,400 \mathrm{ft}$, and the borehole is open to $6,001 \mathrm{ft}$. The liner is slotted from 2,800 to $5,400 \mathrm{ft}$, and the annular space between the liner and borehole is open below 1,735 ft (fig. 30B). The lithology at the saturated part of the open interval in both wells consists mostly of quartzite with some argillite and siltstone, and dolomite (fig. 30; Wood, 2007). Most water in the well originates from the dolomite with some contribution from the overlying quartzite. Hydraulic tests done in UE-15d WW indicate several permeable zones within the quartzite, and that the most permeable zone occurs between 4,441 and 5,330 ft, which includes the quartzite-dolomite contact (R.F. Norvitch, U.S. Geological Survey, written commun., 1962, p. 9).

UE-15d WW was drilled to obtain geologic and hydrologic data of the units penetrated by the borehole (R.F. Norvitch, U.S. Geological Survey, written commun., 1962, p. 1). UE-15d WW later was used for water supply to a farm maintained by the U.S. Environmental Protection Agency in Area 15 from 1965 to 1981 (U.S. Department of Energy, 2004; 2005, p. 60), and also was monitored as part of DOE's hydrologic monitoring network from 1973 to 1990 (Russell, 1989, p. 1; Lyles, 1993, p. 2). About 352 Mgal of water were withdrawn from the borehole from 1962 to 1981 (fig. 31A; appendix A). Well $U E-15 d W W(1735-6001 \mathrm{ft}$ ) was pumped for a 36-hour production test in March 1962 during which about $0.17 \mathrm{Mgal}$ of water were withdrawn from the well. Well UE-15dWW (cased) was pumped in April 1962 and from June 1965 to November 1981, for a total of about 351 Mgal of water withdrawn from the well. Wood and Reiner (1996, p. 9) reported that the pump in the well failed to start and pumping ceased October 7, 1991; however, measured withdrawal data are not available from 1982 to 1991. It is assumed that no withdrawals have occurred since 1991.

Water-level measurements made in UE-15d WW from 1962 to 1983 are shown in figure 31B. One water level was measured in well $U E-15 d W W(1735-6001 \mathrm{ft})$ at a depth of $668 \mathrm{ft}$ below land surface. The water levels in well $U E-15 d$ $W W$ (cased) range from about 667 to $694 \mathrm{ft}$ below land surface. The water level measured in 1980 shows the effects of pumping in the well.

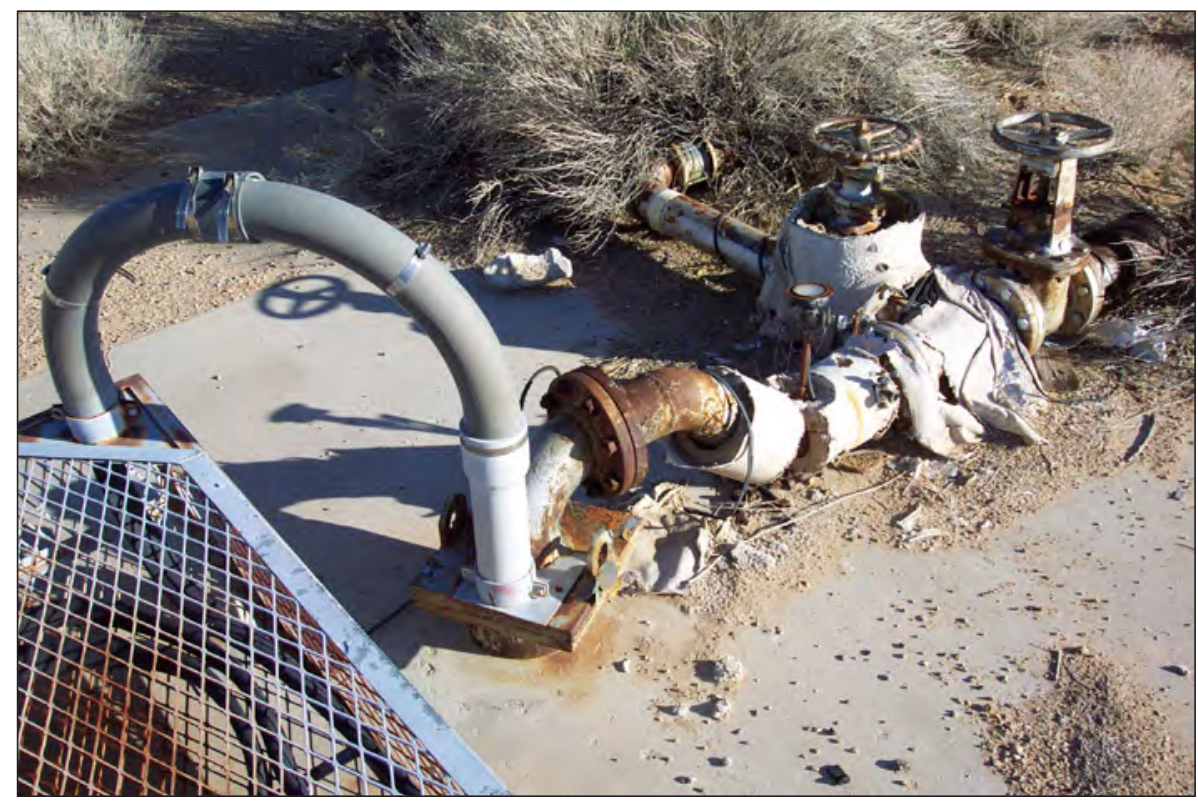

UE-15d WW, circa September 2007. Photograph by Terry L. Miller, U.S. Geological Survey. 
Well name: UE-15d WW (1735-6001 ft)

USGS site identification No.: 371230116021500

Land-surface altitude: 4,586 feet above National Geodetic Vertical Datum of 1929 (NGVD29)

Latitude:-

Longitude:-

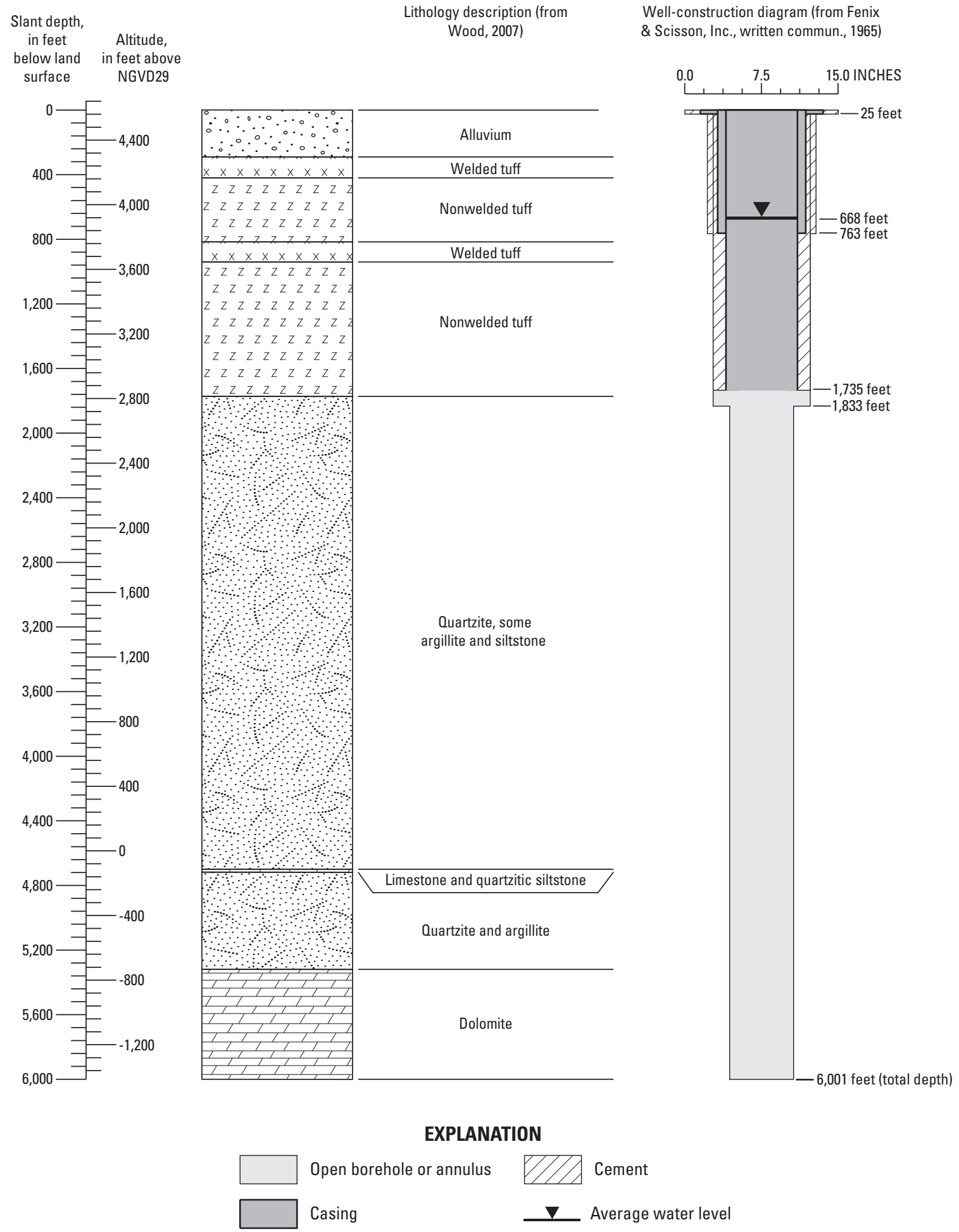

$\boldsymbol{A}$

Figure 30. Borehole lithology and well construction for wells UE-15d WW (1735-6001 ft) and UE-15d WW (cased), Area 15, Nevada National Security Site, Nye County, Nevada. 
Well name: UE-15d WW (cased)

USGS site identification No.: 371230116021501

Land-surface altitude: 4,586 feet above National Geodetic Vertical Datum of 1929 (NGVD29)

Latitude: -

Longitude: -
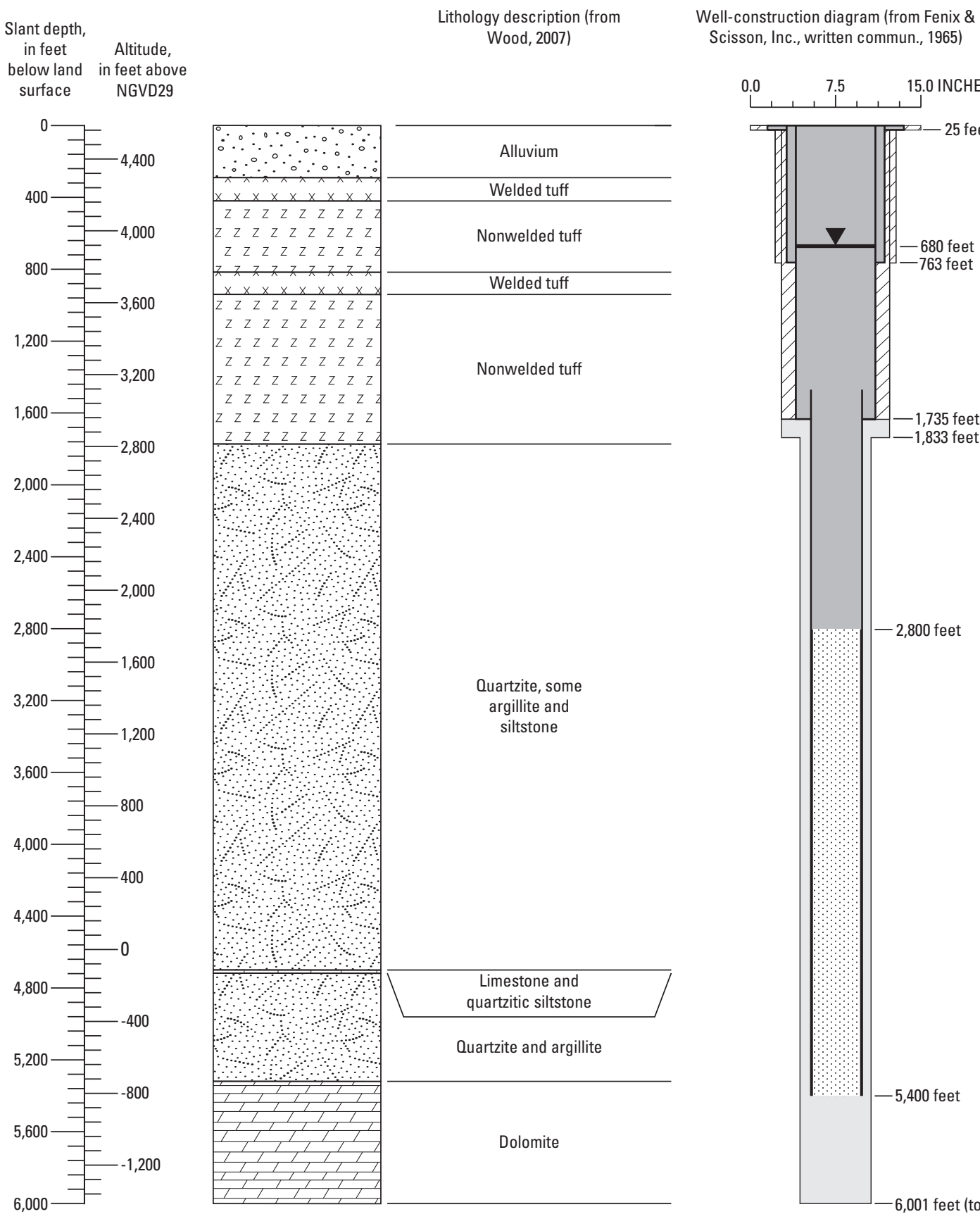

\begin{tabular}{|c|c|}
\hline $\begin{array}{l}\therefore \\
\therefore \\
\therefore\end{array}$ & Alluvium \\
\hline$x \times x \times x \times x \times x \times x$ & Welded tuff \\
\hline $\begin{array}{c}z \quad z \quad z \quad z \quad z \quad z \quad z \quad z \\
z z z z z \quad z \quad z \quad z \\
z \quad z \quad z \quad z \quad z \quad z \quad z \quad z\end{array}$ & Nonwelded tuff \\
\hline
\end{tabular}

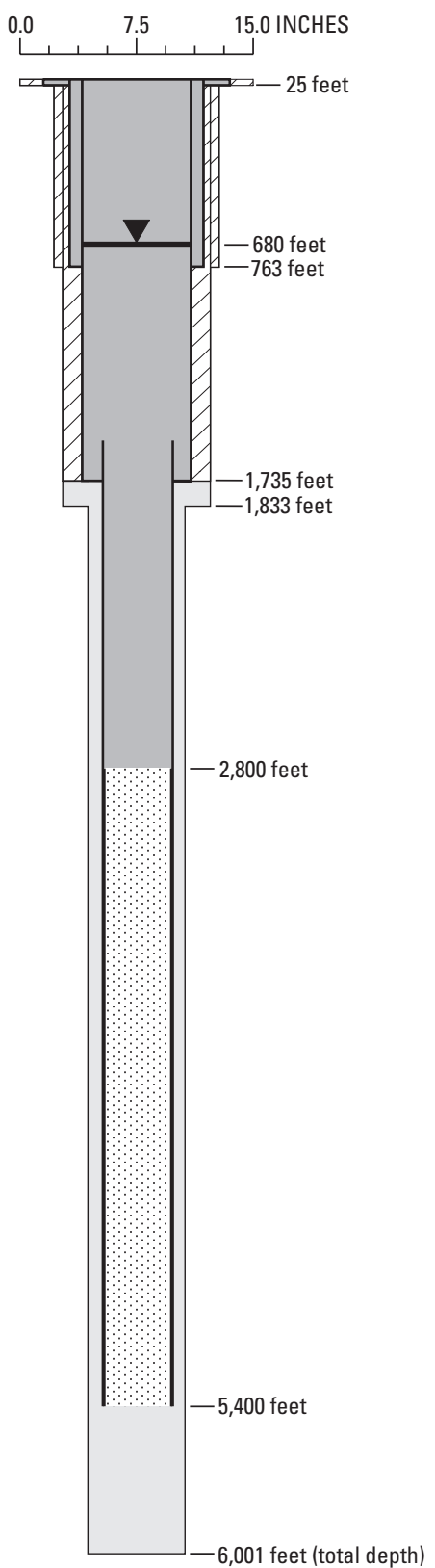

$x \quad x \quad x \quad x \quad x \quad x$
$z z z z z z z z z$

Welded tuff

$\begin{array}{lllllllllll}z & z & z & z & z & z & z & z\end{array}$

$z z z z z Z z \quad z \quad z$

$z Z z Z z Z z Z$

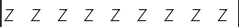

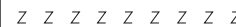

$\begin{array}{lllllllll}z & z & Z & z & z & z & z & z & z\end{array}$

$z z z z z z z z z$

Nonwelded tuff
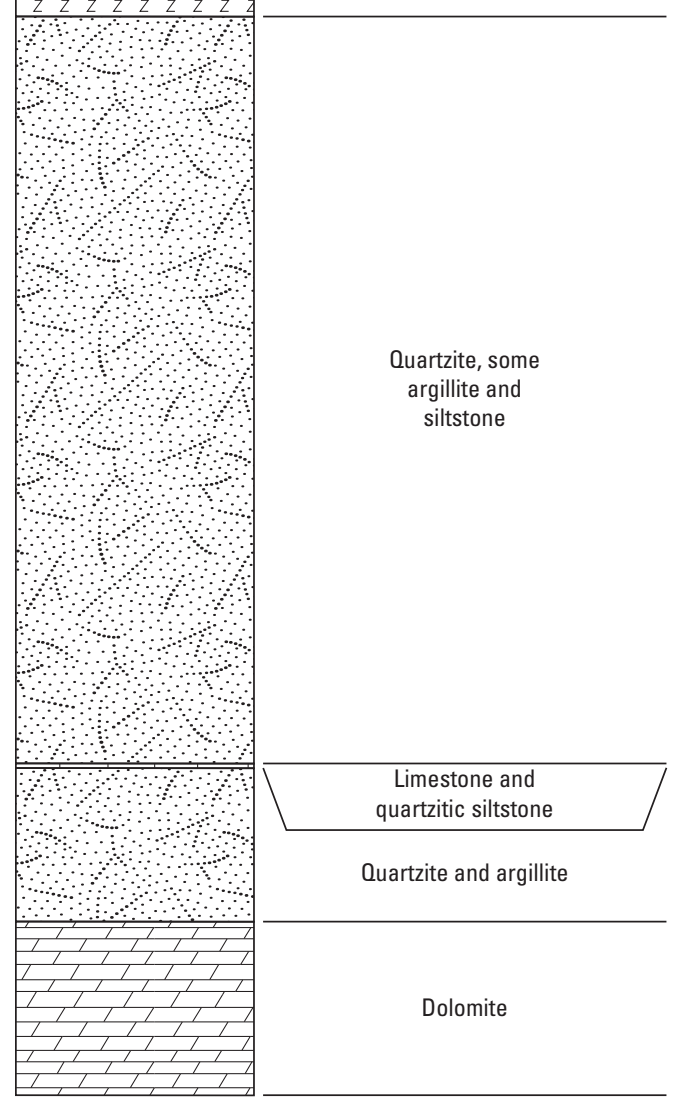

\section{EXPLANATION}

Open borehole or annulus

Slotted or perforated casing Average water level

\section{B} Casing

Cement

Figure 30.-Continued. 

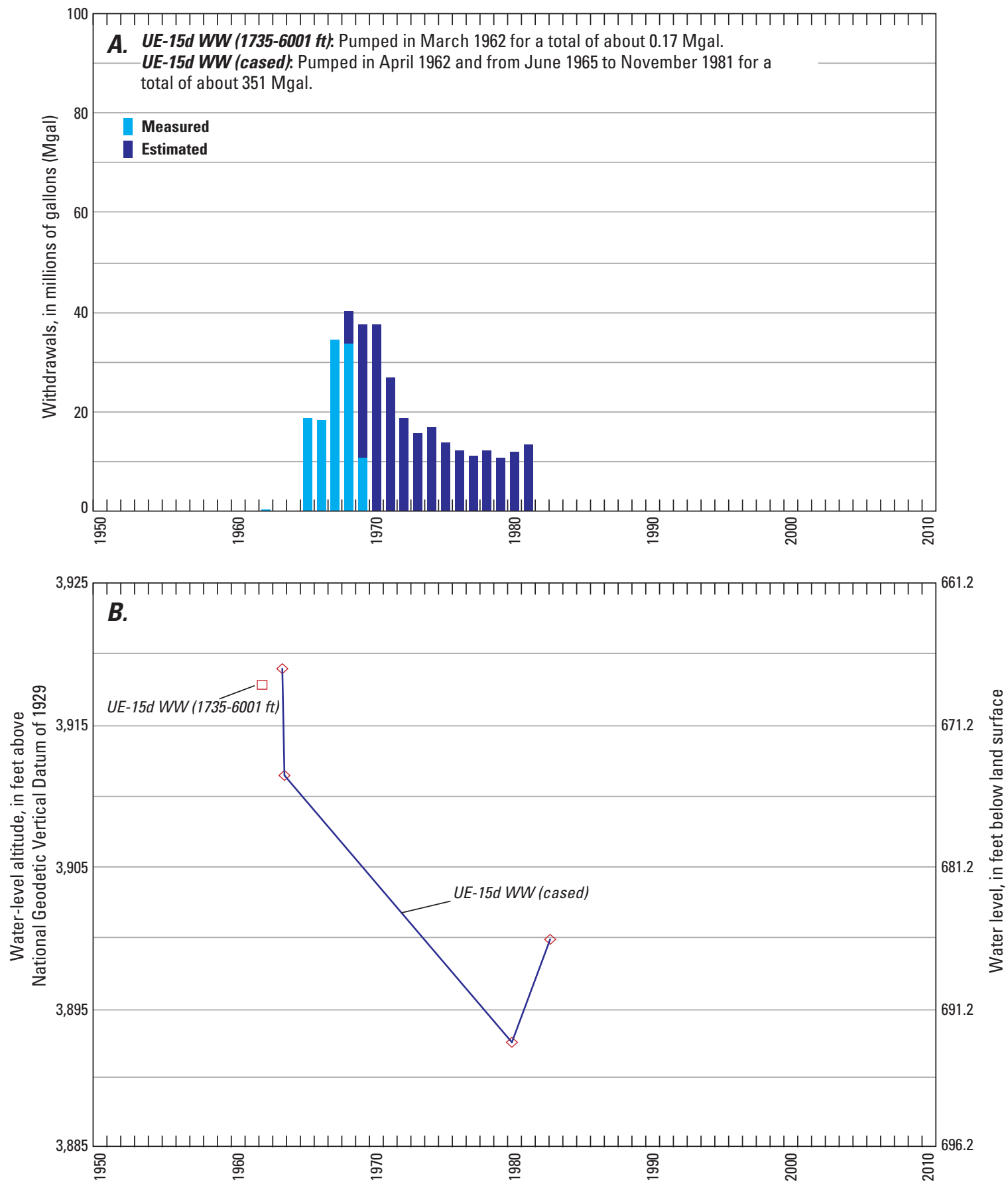

Figure 31. Annual groundwater withdrawals and water levels for wells UE-15d WW (1735-6001 ft) and UE-15d WW (cased), Area 15, Nevada National Security Site, Nye County, Nevada, 1962-2008. 
UE-16d WW.-UE-16d WW is west of Yucca Flat in Area 16 of the NNSS (fig. 1; table 1; UE-16d WW photograph). Construction information for the borehole was compiled from Fenix \& Scisson, Inc., hole history data (written commun., 1977). The borehole was rotary drilled with air foam and mud to a depth of 3,000 ft below land surface in August 1977, and recompleted as a water-supply well in March 1981. Borehole diameter ranges from 26 in. at land surface to $6.25 \mathrm{in}$. at the bottom of the hole.

Borehole UE-16d WW has one completion interval, well $U E-16 d W W$, which includes casing to a depth of 2,117 ft with perforations from 1,145 to 1,310 ft. The annular space between the casing and borehole is open from $81 \mathrm{ft}$ to $1,944 \mathrm{ft}$ (fig. 32). The lower, uncased part of the borehole was sealed off when a bridge plug was installed at a depth of 2,020 ft. The lithology at the saturated part of the open interval consists of siltstone, limestone, quartzite, and argillite (fig. 32; Dinwiddie and Weir, 1979, p. 5; Wood, 2007). The principle waterbearing unit in the well is the carbonate rocks (Gillespie and others, 1996b, p. 27).

UE-16d WW originally was drilled to obtain geologic and hydrologic data of the units penetrated by the borehole (Dinwiddie and Weir, 1979, p. 1). UE-16d WW later was used for water supply, and also has been part of DOE's hydrologic monitoring network since 1982 (Russell, 1989; Bechtel Nevada, 2003; U.S. Department of Energy, 2008, p. 7-6). Groundwater withdrawals from well $U E-16 d W W$ were estimated to be almost $787 \mathrm{Mgal}$ since it began pumping continuously for water supply in 1981 (fig. 33A; appendix A).

One water level was measured in well $U E-16 d W W$ in 1981 (fig. 33B) at a depth of $753 \mathrm{ft}$ below land surface. This water level was measured only 12 hours after water had been air jetted from the well.

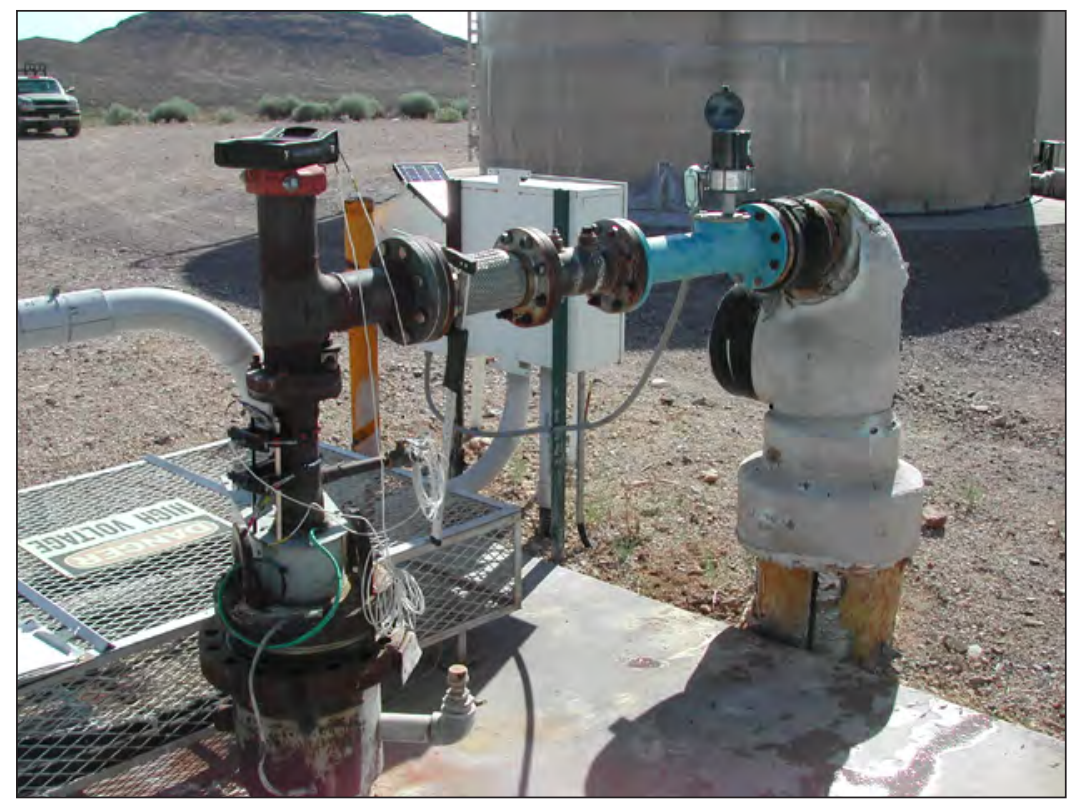

UE-16d WW, July 2005. Photograph by Richard J. La Camera, U.S. Geological Survey. 


\section{Well name: UE-16d WW}

USGS site identification No.: 370412116095101

Land-surface altitude: 4,684 feet above National Geodetic Vertical Datum of 1929 (NGVD29)

Latitude:-

Longitude:-

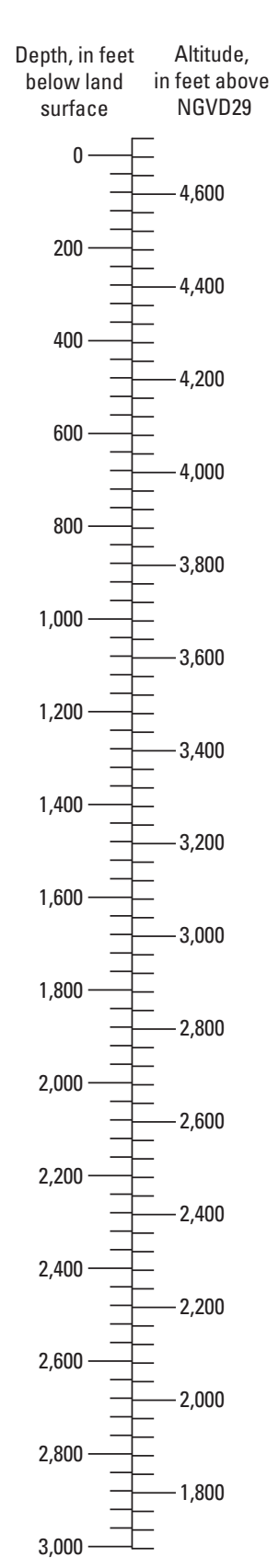

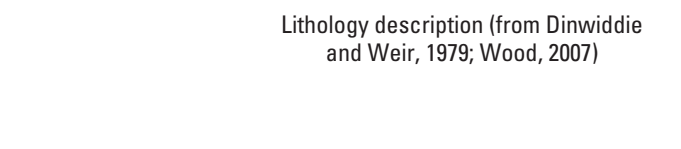

Well-construction diagram (from Fenix \&
Scisson, Inc., written commun., 1977)
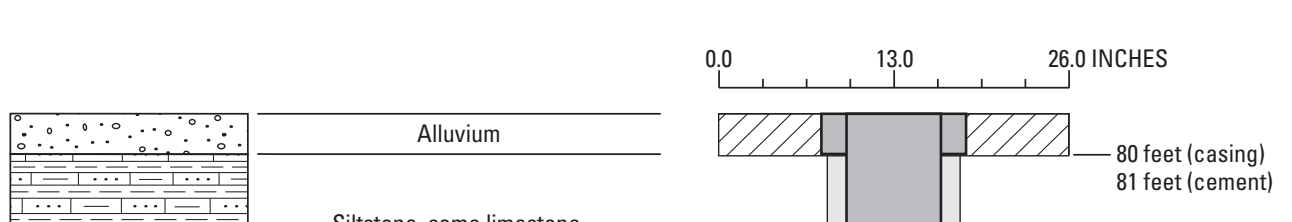

Siltstone, some limestone
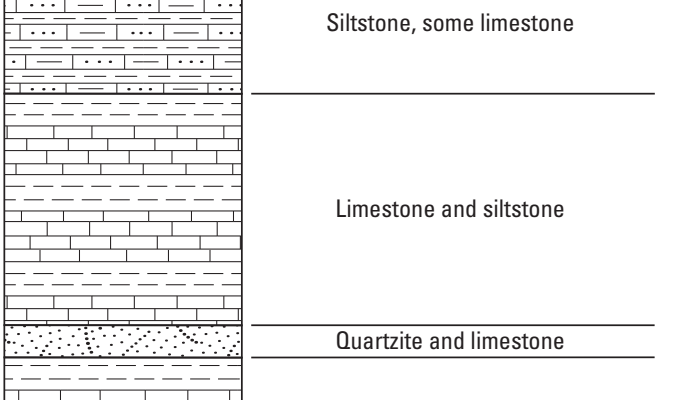

Limestone, some argillite, quartzite, siltstone

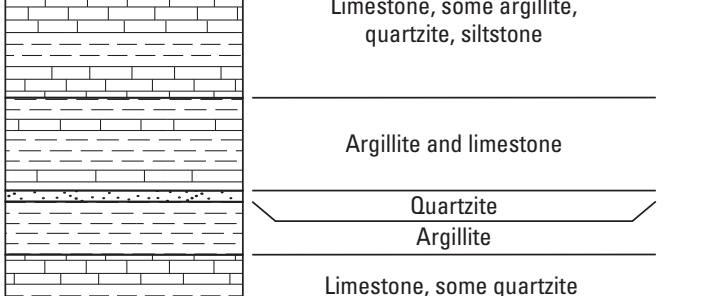

\begin{tabular}{|c|c|}
\hline \begin{tabular}{ll|l|l|} 
& & & \\
\end{tabular} & Limestone, some quartzite \\
\hline $\begin{array}{c}\cdots \\
\cdots \\
\cdots\end{array} \cdots \cdots$ & Siltstone and quartzite \\
\hline
\end{tabular}
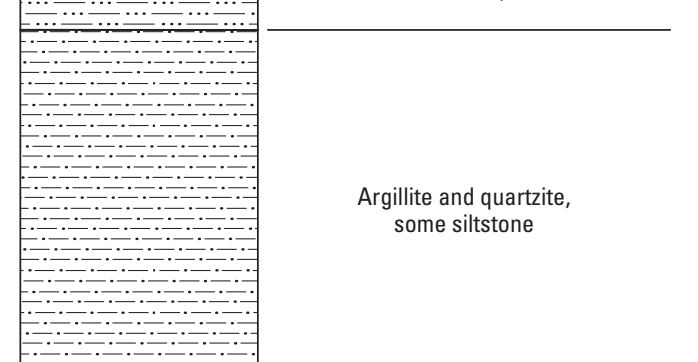

illite and quartzite,

\begin{tabular}{c} 
\\
\hline
\end{tabular}

Argillite, some quartzite

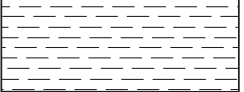



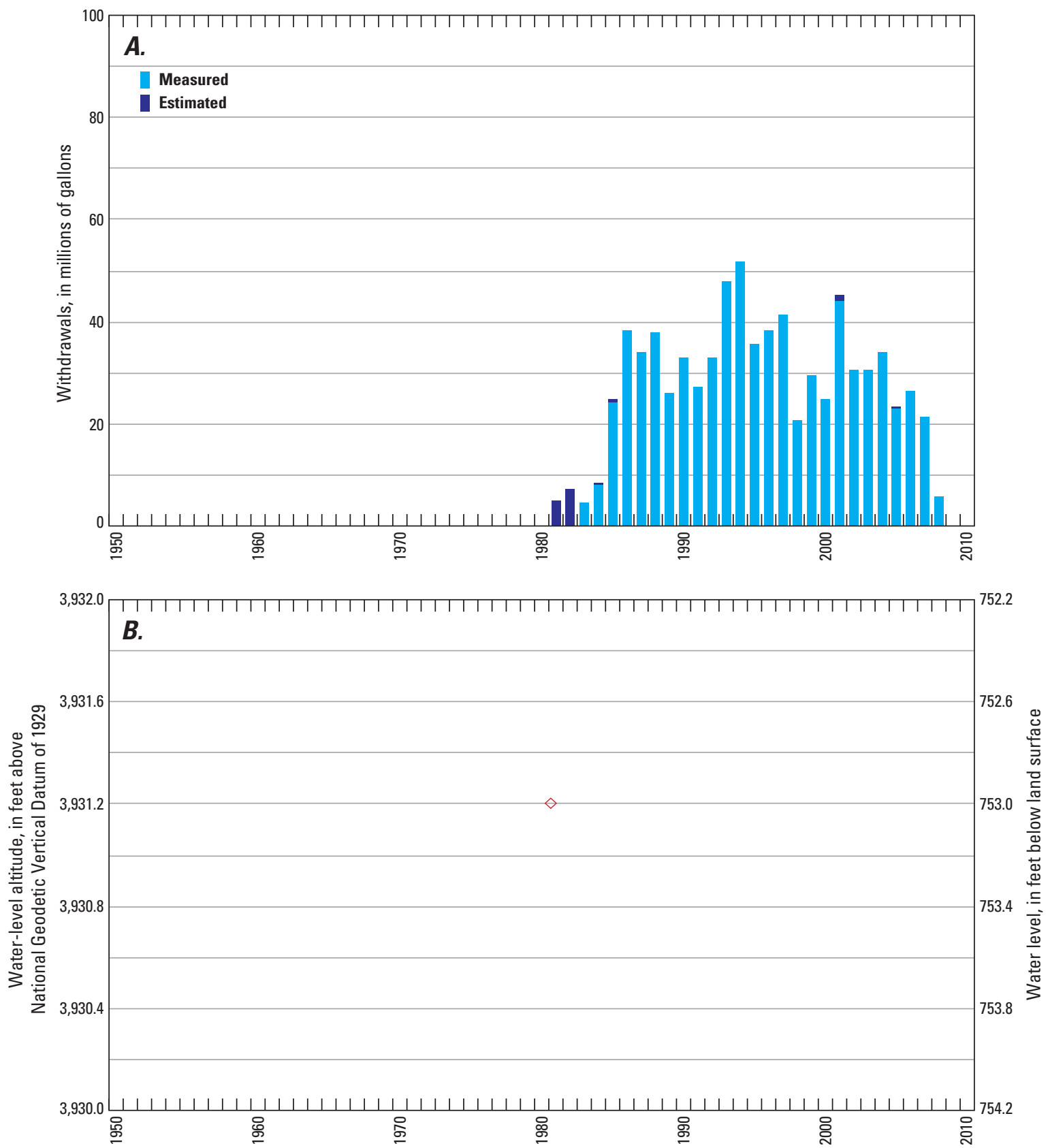

Figure 33. Annual groundwater withdrawals and water levels for well UE-16d WW, Area 16, Nevada National Security Site, Nye County, Nevada, 1981-2008. 
UE-19b 1 WW.-UE-19b 1 WW is on Pahute Mesa in Area 19 of the NNSS (ig. 1; table 1; UE-19b 1 WW photograph not available). Construction information for the borehole was compiled from Fenix \& Scisson, Inc. well history data (written commun., 1964), and Thordarson and others (1967). The borehole was drilled and completed to a depth of 4,500 ft below land surface in June 1964 using the air-rotary method. Borehole diameter ranges from 26 in. at land surface to 9.88 in. at the bottom of the hole.

Borehole UE-19b $1 \mathrm{WW}$ has a single completion interval, well $U E-19 b 1 \mathrm{WW}$, which includes casing to a depth of 2,190 ft and an open borehole to 4,500 ft (fig. 34). Based on nearby borehole UE-19b, the lithology at the saturated part of the open interval in well $U E-19 b 1 \mathrm{WW}$ consists of lava and welded tuff (fig. 34; Wood, 2007). The well produces water from permeable zones in the upper part of the rhyolitic lava flow between the intervals 2,610 to 2,640 ft and 2,720 to 2,760 ft (Blankennagel and Weir, 1973).
UE-19b 1 WW was drilled to obtain geologic and hydrologic data of the units penetrated by the borehole (R.K. Blankennagel and J.E. Weir, U.S. Geological Survey, written commun., 1965, p. 3). Well UE-19b 1 WW was used for water supply (Thordarson and others, 1967, p. 22) from June 1964 to August 1965. Almost $7 \mathrm{Mgal}$ of water were withdrawn from the well during this time (fig. 35A; appendix A). The well was plugged with cement in May 1966 (Bechtel Nevada, written commun., 2002).

Two water-level measurements were made in well UE-19b 1 WW during 1964 and 1965 (fig. 35B). These measurements are about 2,117 ft below land surface. The first measurement is a pre-pumping level, and the second measurement was made after the well had been pumping for about 1 month. 
Well name: UE-19b 1 WW

USGS site identification No.: 371852116175701

Land-surface altitude: 6,802 feet above National Geodetic Vertical Datum of 1929 (NGVD29)

Latitude: $37^{\circ} 18^{\prime} 52^{\prime \prime}$

Longitude: $116^{\circ} 17^{\prime} 57^{\prime \prime}$
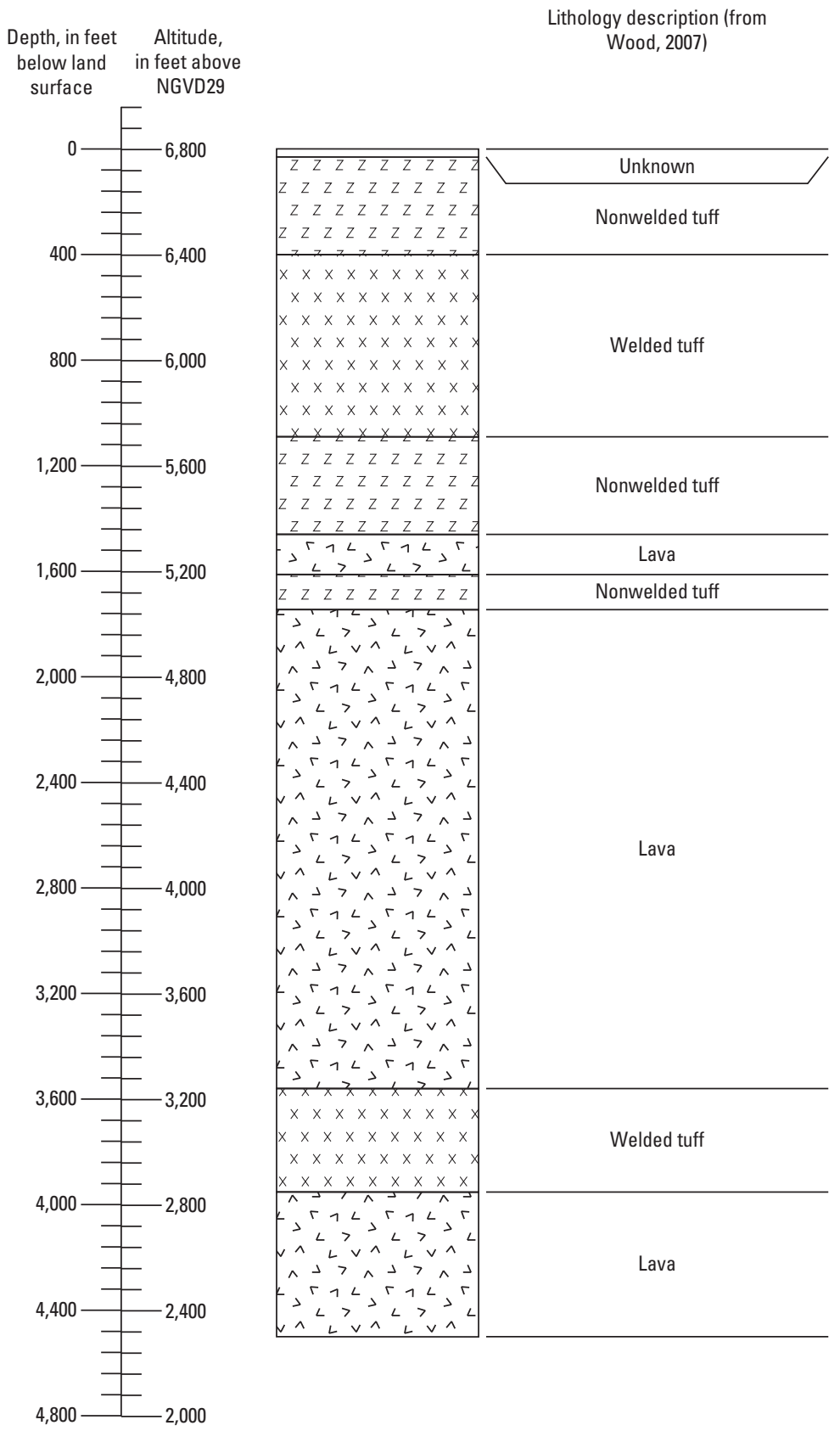

Well-construction diagram (from Fenix

\& Scisson, Inc., written commun., 1964

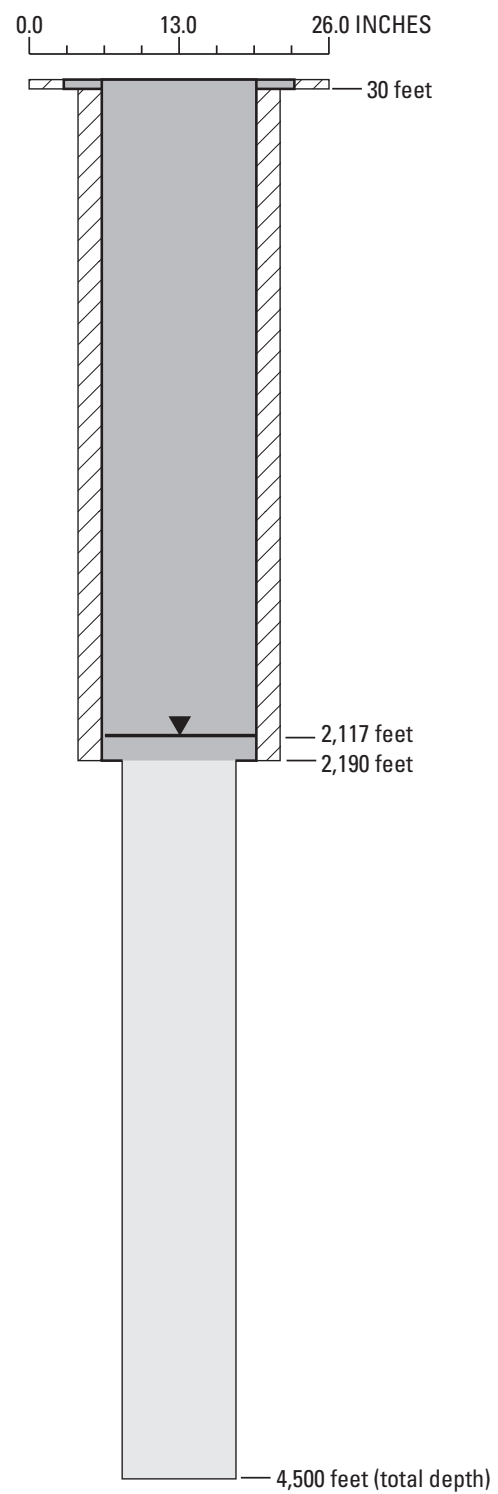

EXPLANATION

$\square$ Open borehole or annulus
$\square$ Casing

Figure 34. Borehole lithology and well construction for well UE-19b 1 WW, Area 19, Nevada National Security Site, Nye County, Nevada. 

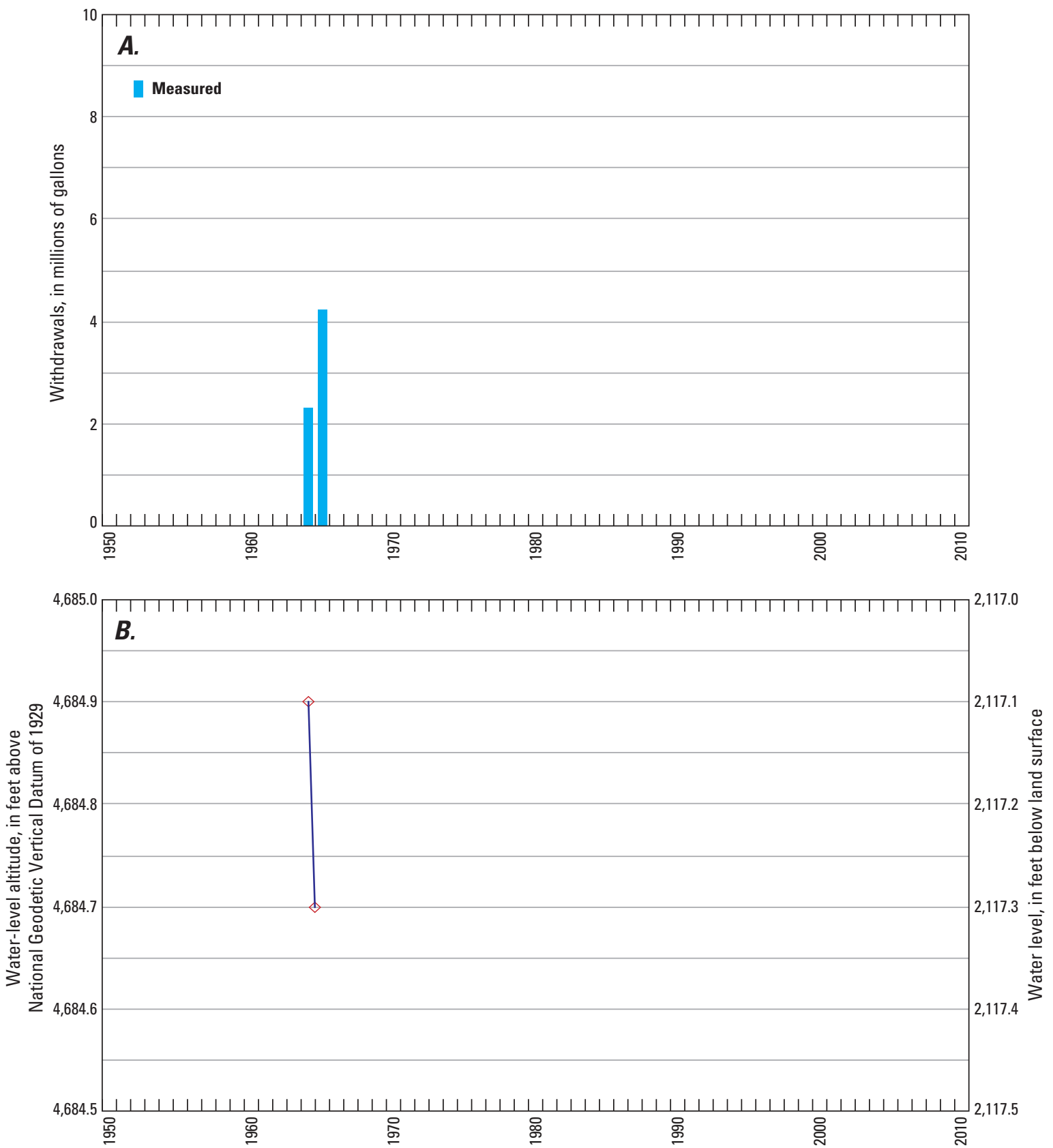

Figure 35. Annual groundwater withdrawals and water levels for well UE-19b 1 WW, Area 19, Nevada National Security Site, Nye County, Nevada, 1964-66. 
UE-19c WW.-UE-19c WW is on Pahute Mesa in Area 19 of the NNSS (fig. 1; table 1; UE-19c WW photograph). Construction information for the borehole was compiled from Fenix \& Scisson, Inc., hole history data (written commun., 1967), Thordarson and others (1967), and U.S. Department of Energy (1996d). The borehole was drilled and completed to a depth of 8,489 ft below land surface in June 1964 using the conventional circulation method with air mist. Borehole diameter ranges from $26 \mathrm{in}$. at land surface to $9.88 \mathrm{in}$. at the bottom of the hole.

Borehole UE-19c WW has one completion interval, well $U E-19 c W W$, which includes casing to a depth of 2,421 ft and an open borehole to 8,489 ft (fig. 36). A $5.5 \mathrm{in}$. pump tube and a 1.6 in. water-level access tube were installed to depths of 2,569 and 2,493 ft, respectively, in the well. The pump tube has a screened intake at 2,528 ft, and the access tube is joint slotted and orange peeled at a depth of 2,493 ft; the exact dimensions of these openings are not available and therefore are estimated in figure 36. The lithology at the saturated part of the open interval consists of nonwelded and welded tuffs, lava, and flow breccia (fig. 36; Warren and others, 2003). The well is open to two water-producing zones within the volcanic rocks as indicated by changes in temperature gradients on geophysical logs (Blankennagel, 1968, p. 27). The upper, major contributing zone extends from 3,070 to 3,090 ft below land surface, and the lower, minor contributing zone extends from 3,090 to 3,160 ft.

UE-19c WW was drilled to obtain geologic and hydrologic data of the units penetrated by the borehole (R.K. Blankennagel and J.E. Weir, U.S. Geological Survey, written commun., 1965, p. 3). Well $U E-19 c W W$ was used for water supply to Area 19 (Russell, 1989, p. 32), and was monitored as part of DOE's hydrologic monitoring network from 1975 to 1999 (Russell, 1989; Townsend and Grossman, 2000, p. 5-5). Based on available data, the well was pumped continuously from July 1975 to October 1992, and sporadically through September 1994. Groundwater withdrawals from the well during this time are estimated to be about 1,050 Mgal (fig. 37A; appendix A).

Periodic water-level measurements made in the waterlevel access tube in well UE-19c WW since 1974 are shown in figure 37B. The water levels range from about 2,337 to $2,345 \mathrm{ft}$ below land surface. The initial measurement represents pre-pumping levels, and all measurements made after 1994 represent post-pumping levels. Water levels have been fairly consistent since about 1996 after 17 years of continuous pumping that ceased in 1992 and sporadic pumping through 1994.

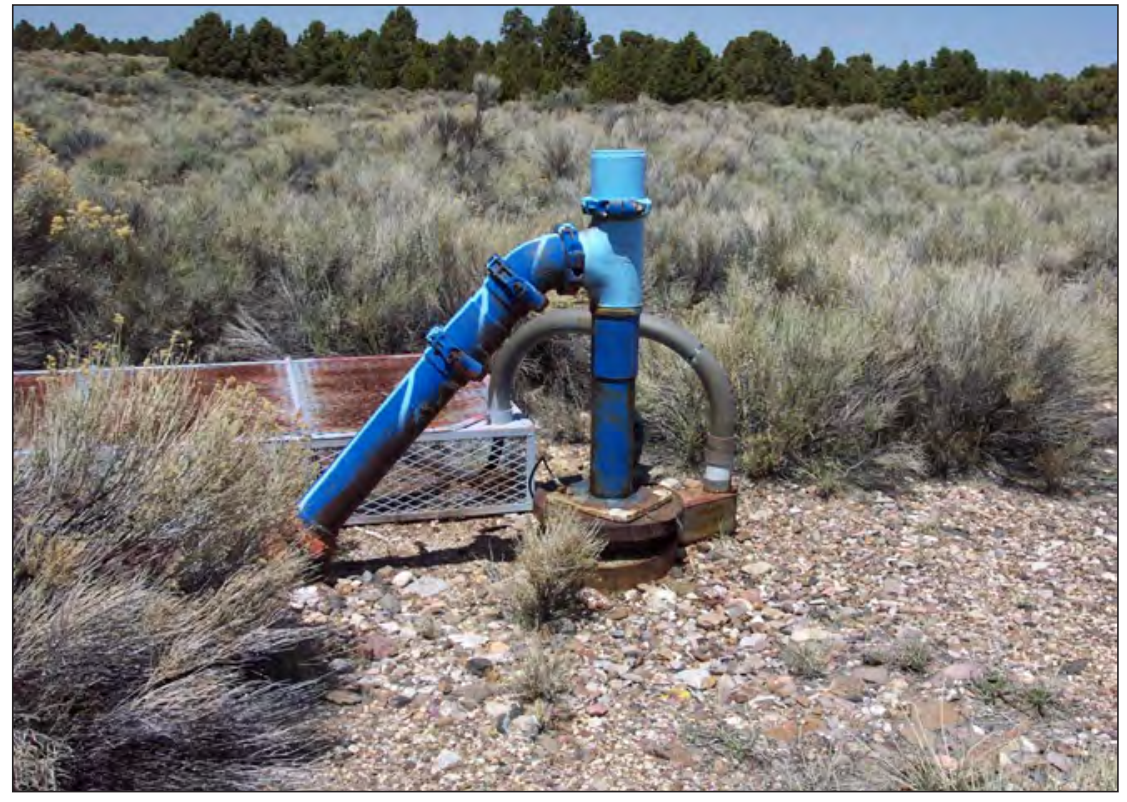

UE-19c WW, April 2009. Photograph by Terry L. Miller, U.S. Geological Survey. 


\section{Well name: UE-19c WW}

USGS site identification No.: 371608116191002

Land-surface altitude: 7,033 feet above National Geodetic Vertical Datum of 1929 (NGVD29)

Latitude:-

Longitude:-

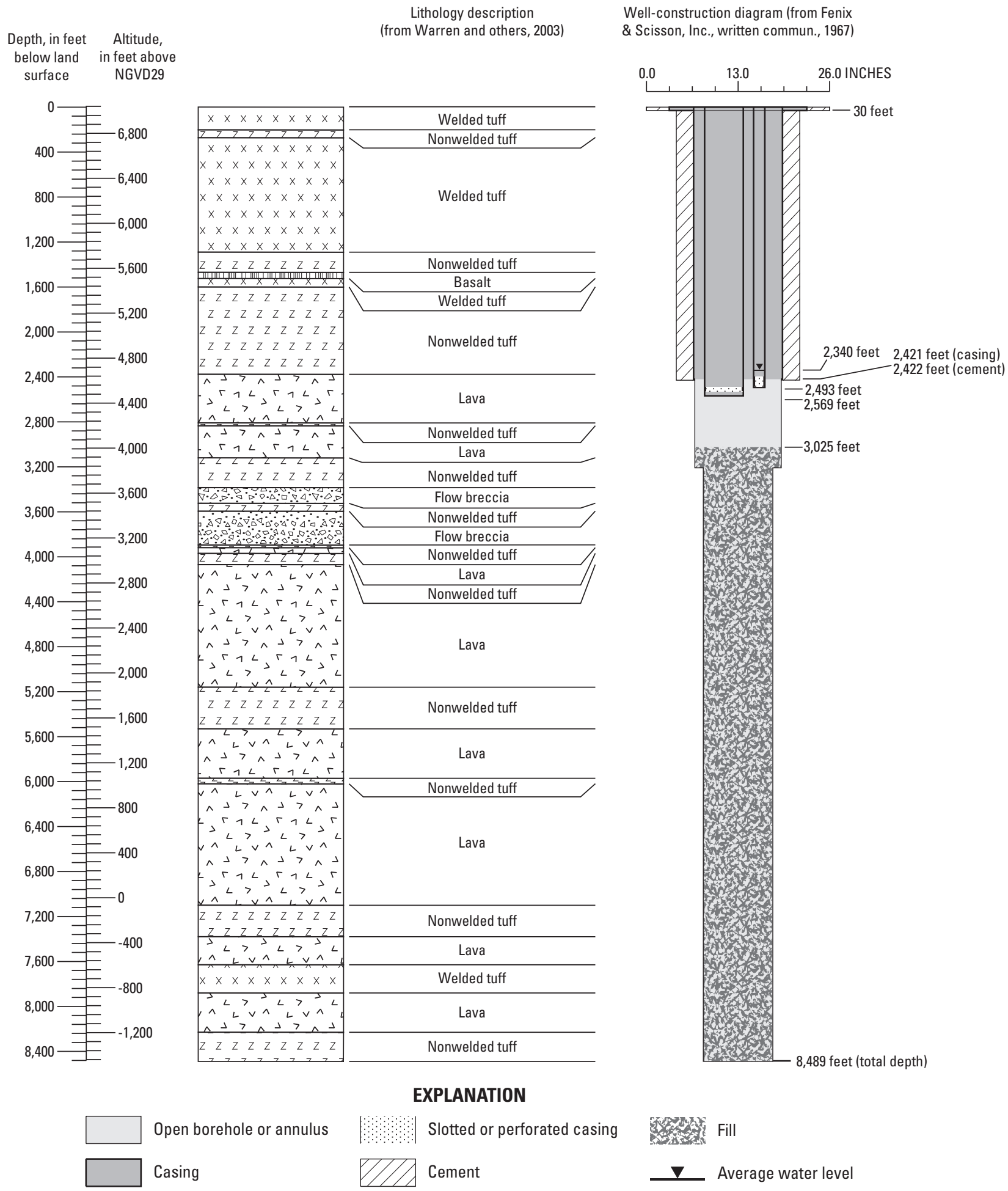

Figure 36. Borehole lithology and well construction for well UE-19c WW, Area 19, Nevada National Security Site, Nye County, Nevada. 

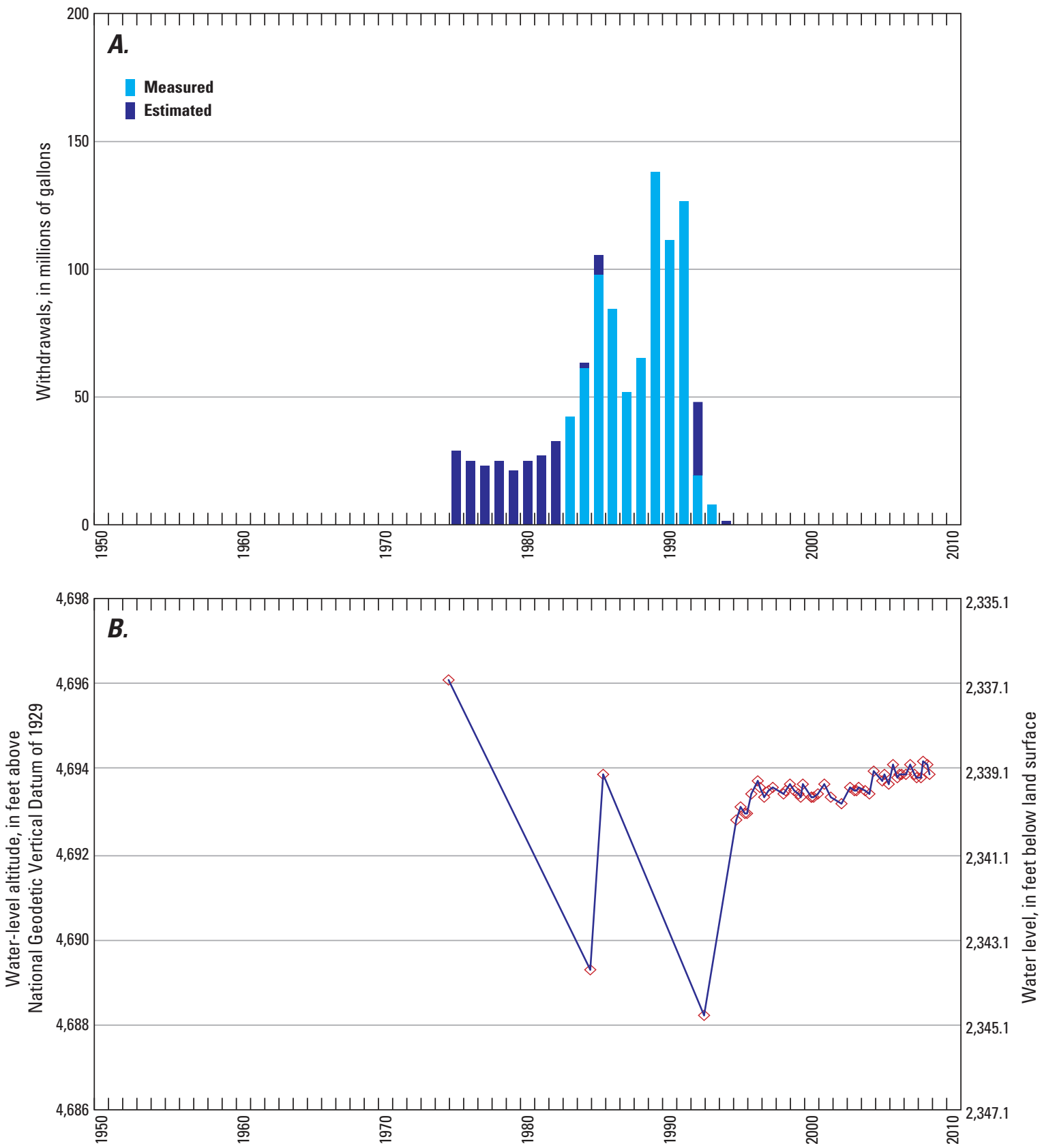

Figure 37. Annual groundwater withdrawals and water levels for well UE-19c WW, Area 19, Nevada National Security Site, Nye County, Nevada, 1974-2008. 
UE-19e WW.-UE-19e WW is on Pahute Mesa in Area 19 of the NNSS (fig. 1; table 1; UE-19e WW photograph not available). Construction information for the borehole was compiled from Fenix \& Scisson, Inc., hole history data (written commun., 1965). The borehole was drilled and completed to a depth of 6,005 ft below land surface in August 1964 using the air-rotary method. Borehole diameter ranges from 26 in. at land surface to 9.88 in. at the bottom of the hole $(6,005 \mathrm{ft})$.

Borehole UE-19e WW has one completion interval, well $U E-19 e W W$, which includes casing to a depth of 2,475 ft and an open borehole to 6,005 ft (ig. 38). The lithology at the saturated part of the open interval consists of nonwelded and welded tuffs, and lava (fig. 38; Warren and others, 2003). Two permeable zones in the lava were encountered in the hole. The first, upper zone was from 2,650 to $2,690 \mathrm{ft}$, and the second, lower zone was from 4,970 to 4,990 ft (R.K. Blankennagel, U.S. Geological Survey, written commun., no date).
UE-19e WW was drilled as an exploratory hole (Thordarson and others, 1967, p. 22), and later was used for water supply. Well $U E-19 e$ WW was used to supply water for drilling of the emplacement hole U-19e (R.K. Blankennagel, U.S. Geological Survey, written commun., no date, p. 14), which occurred from May 1965 to March 1966. The well continued to be pumped through 1969; no known withdrawals occurred after 1969. Almost $62 \mathrm{Mgal}$ of water were withdrawn from the well from 1965 to 1969 (fig. 39A; appendix A). The well was grouted and plugged to the surface in September 1975 (Fenix \& Scisson, Inc., written commun., 1965).

Water-level measurements made in well $U E-19 e W W$ during 1964 and 1965 are shown in figure 39B. The water levels range from about 2,217 to 2,218 ft below land surface. These water levels represent pre-pumping conditions in the aquifer. The first measurement was made 2 days after water was injected into the well. 
Well name: UE-19e WW

USGS site identification No.: 371750116195901

Land-surface altitude: 6,919 feet above National Geodetic Vertical Datum of 1929 (NGVD29)

Latitude: $37^{\circ} 17^{\prime} 50^{\prime \prime}$

Longitude: $116^{\circ} 19^{\prime} 59^{\prime \prime}$

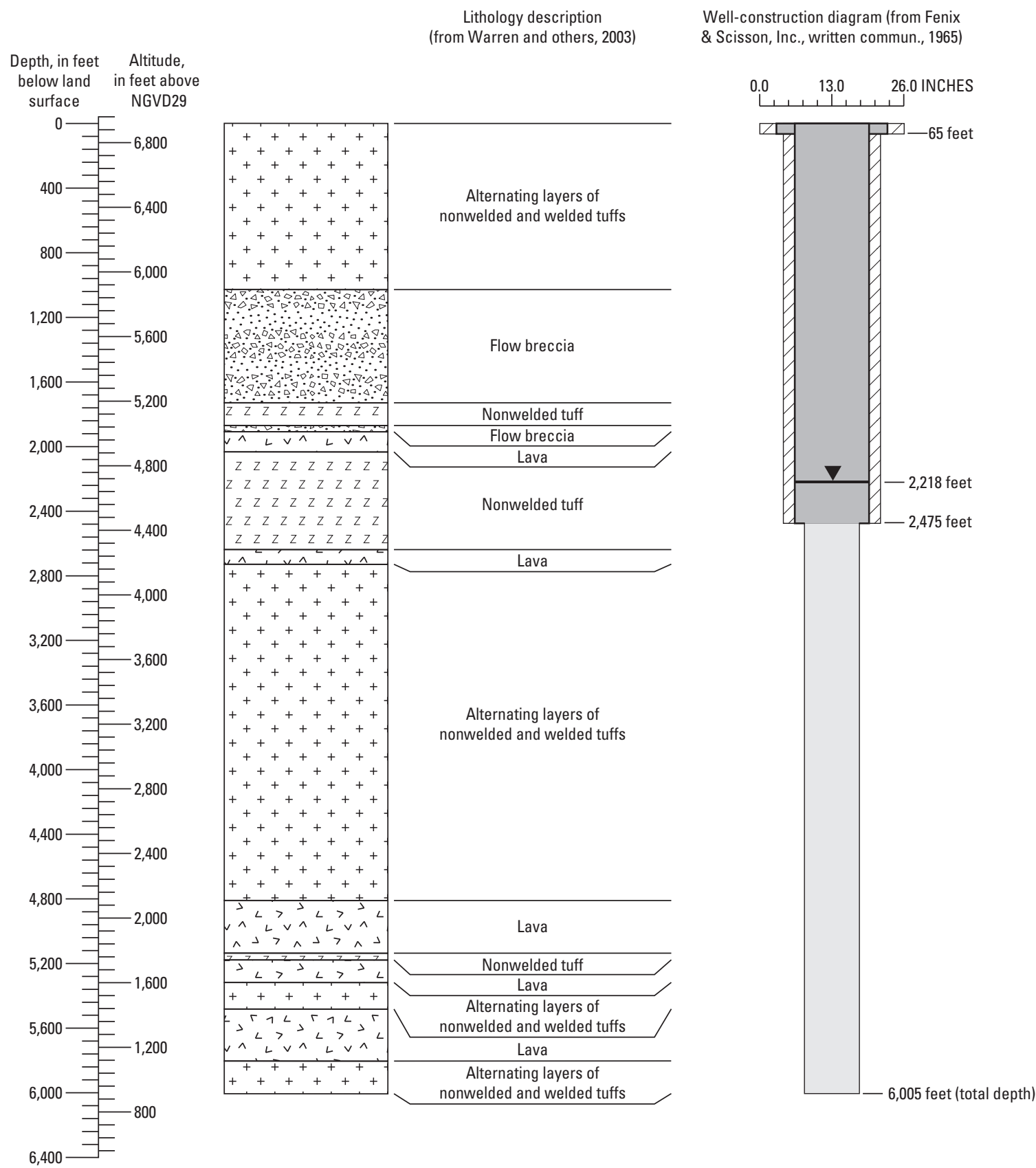

EXPLANATION

$\square$ Open borehole or annulus
$\square$ Casing

Figure 38. Borehole lithology and well construction for well UE-19e WW, Area 19, Nevada National Security Site, Nye County, Nevada. 

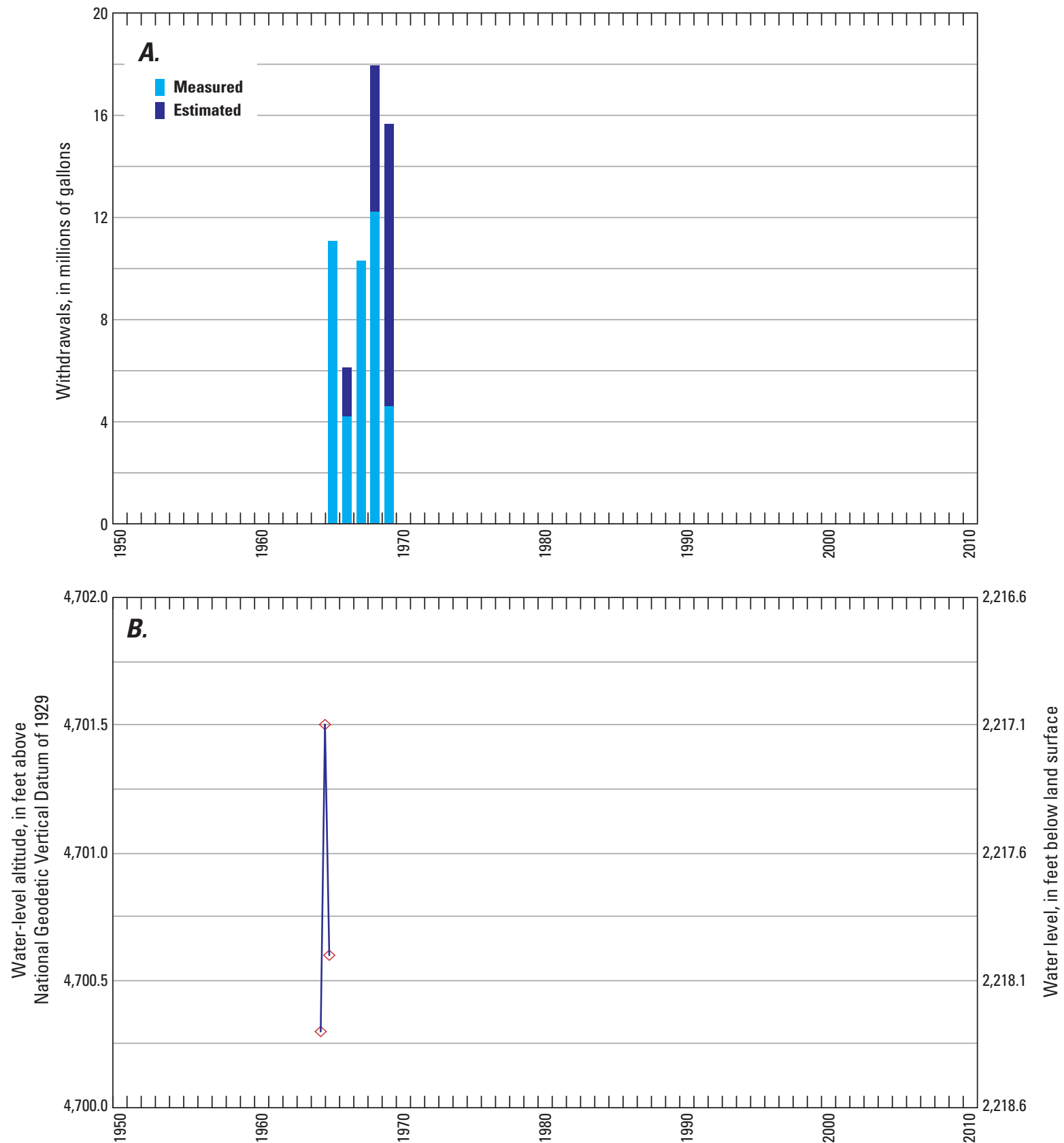

Figure 39. Annual groundwater withdrawals and water levels for well UE-19e WW, Area 19, Nevada National Security Site, Nye County, Nevada, 1964-75. 
UE-19gS. - UE-19gS is on Pahute Mesa in Area 19 of the NNSS (fig. 1; table 1; UE-19gS photograph). Construction information for the borehole was compiled from Fenix \& Scisson, Inc., hole history data (written commun., 1965). The borehole was drilled using the air-rotary method to a depth of 4,508 ft in March 1965, and then was deepened to a total depth of 7,500 in May 1965. Borehole diameter ranges from 26 in. at land surface to $7.88 \mathrm{in}$. at the bottom of the hole $(7,500 \mathrm{ft})$.

Borehole UE-19gS has two completion intervals, well UE-19gS (2650-4508 ft) and well UE-19gS (2650-7500 ft). Well UE-19gS (2650-4508 ft) represents the borehole as it was completed in March 1965. This first completion contains casing to a depth of 2,650 ft and an open borehole to 4,508 ft (fig. 40A). The lithology at the saturated part of the open interval consists of flow breccia, nonwelded tuff, and lava.

UE-19gS was recompleted in May 1965 after the borehole was deepened to a total depth of 7,500 ft. This second well completion, UE-19gS (2650-7500 ft), contains casing from land surface to 2,650 ft and 4,113 to 4,349 ft. The borehole is open from 2,650 to about 4,113 ft and 4,350 to $7,500 \mathrm{ft}$ (fig. 40B). The lithology at the saturated part of the open interval consists mostly of alternating layers of nonwelded and welded tuffs, with some layers of lava and flow breccia (Warren and others, 2003). Two water-bearing zones were encountered in the borehole (K.A. Sargent, U.S. Geological Survey, written commun., 1965, p. 7). The first, upper zone was from 2,802 to 2,970 ft in dense rhyolite and densely welded ash-flow tuff. The second, lower zone was from 4,636 to 4,834 ft in densely welded tuff. The zone of greatest permeability was in the lower interval from 4,786 to $4,790 \mathrm{ft}$.

UE-19gS originally was drilled as an exploratory hole (Thordarson and others, 1967, p. 22), and was part of DOE's hydrologic monitoring network from 1973 to 1975 (Russell, 1989, p. 33). More than $133 \mathrm{Mgal}$ of water were withdrawn from the borehole from 1965 to 1971 (fig. 41A; appendix A). Well UE-19gS (2650-4508 ft) was used only for hydraulic testing. It was pumped for a 24-hour production test from March 26 to 27, 1965, during which a total of 0.27 Mgal were withdrawn from the well (R.K. Blankennagel and J.E. Weir, U.S. Geological Survey, written commun., 1965, p. 14). Pumping in well $U E$-19gS (2650-7500 ft) occurred from 1966 to 1969 , and briefly in March 1971 for a production test. The well was plugged to the surface with cement on January 14, 1976 (Bechtel Nevada, written commun., 2002).

Water-level measurements made in UE-19gS from 1965 to 1971 are shown in figure $41 B$. The water levels range from about 2,042 to 2,043 ft below land surface in well $U E-19 g S$ (2650-4508 ft), and 2,044 to 2,047 ft below land surface in well UE-19gS (2650-7500 ft). Water levels in 1965 are prepumping levels measured prior to the 24-hour production test done in well UE-19gS (2650-4508 ft). During the test, the well was pumped at $185 \mathrm{gal} / \mathrm{min}$, and water levels declined as much as $37 \mathrm{ft}$ (not shown in fig. 41B) but were nearly recovered 15 hours after the pump was shut off. Water levels in 1966 are equilibrated levels measured within about 40 minutes after the pump was shut off from a 12-hour step drawdown test done in well $U E-19 g S$ (2650-7500 ft).

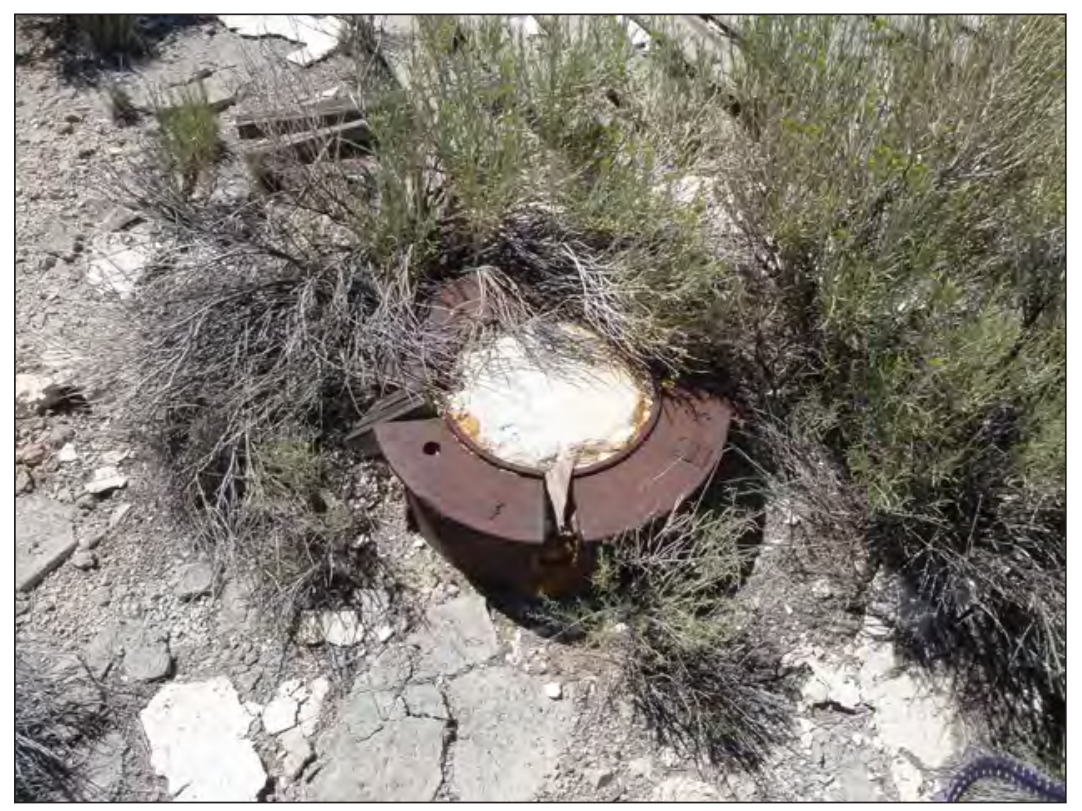

UE-19gS, August 2009. Photograph by Terry L. Miller, U.S. Geological Survey. 
Well name: UE-19gS (2650-4508 ft)

USGS site identification No.: 371830116215300

Land-surface altitude: 6,719 feet above National Geodetic Vertical Datum of 1929 (NGVD29)

Latitude: $37^{\circ} 18^{\prime} 30^{\prime \prime}$

Longitude: $116^{\circ} 21^{\prime} 53^{\prime \prime}$

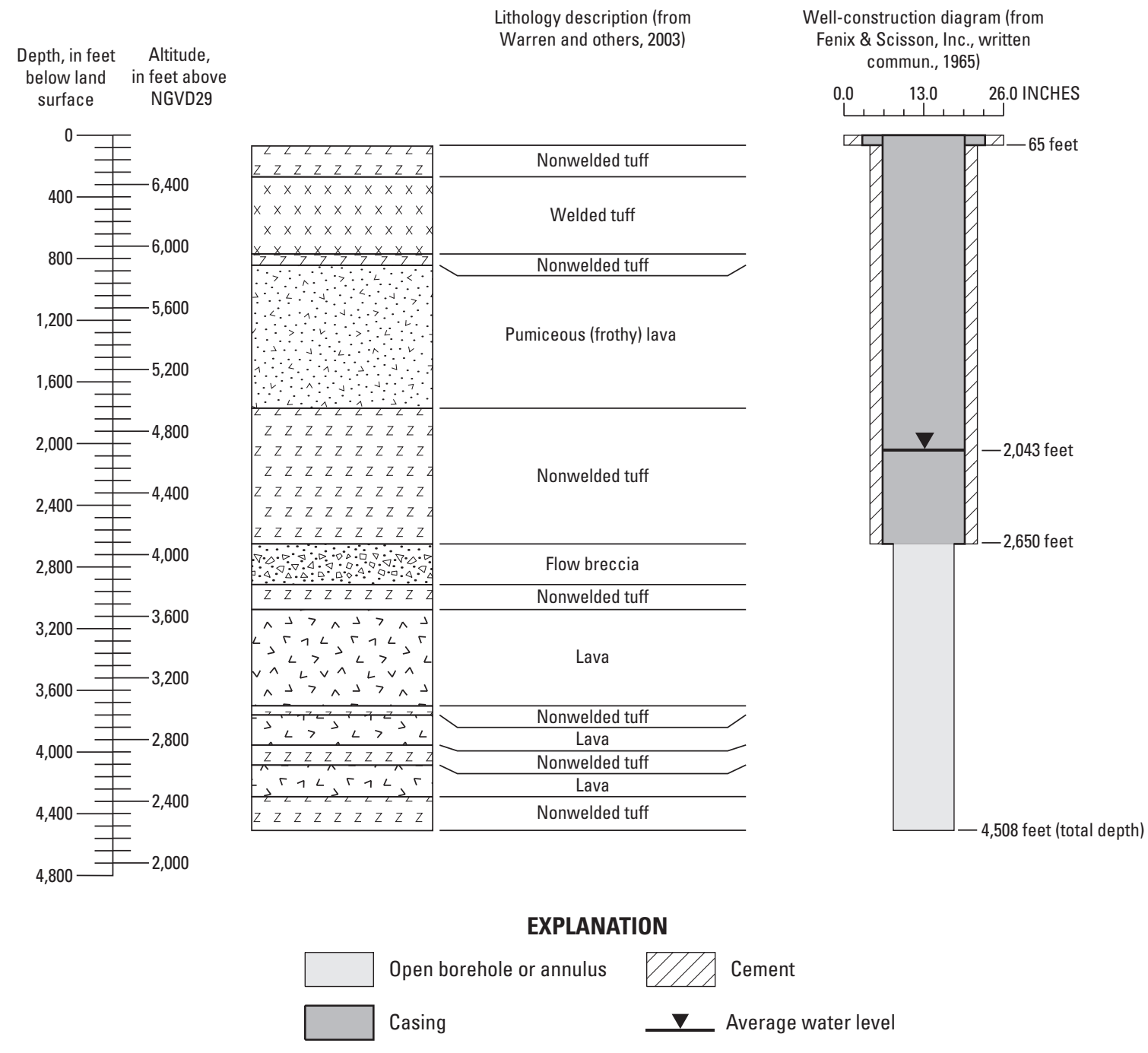

$\boldsymbol{A}$

Figure 40. Borehole lithology and well construction for wells UE-19gS (2650-4508 ft) and UE-19gS (2650-7500 ft), Area19, Nevada National Security Site, Nye County, Nevada. 
Well name: UE-19gS (2650-7500 ft)

USGS site identification No.: 371830116215303

Land-surface altitude: 6,719 feet above National Geodetic Vertical Datum of 1929 (NGVD29)

Latitude: $37^{\circ} 18^{\prime} 30^{\prime \prime}$

Longitude: $116^{\circ} 21^{\prime} 53^{\prime \prime}$

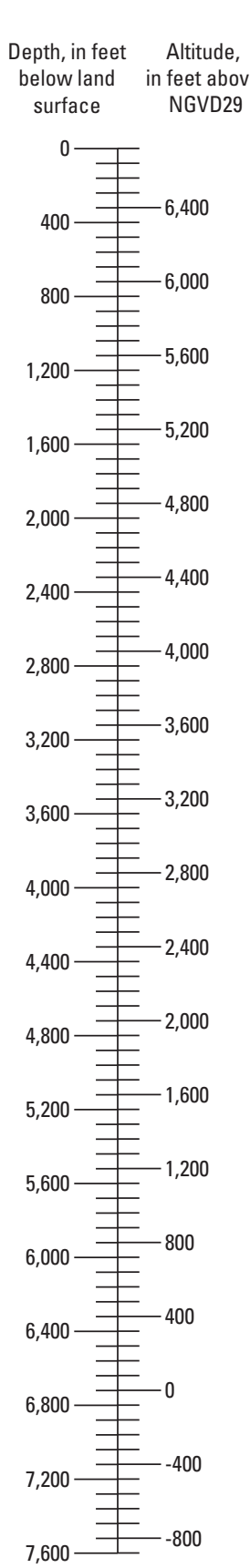

\begin{tabular}{|c|c|}
\hline & $\begin{array}{l}\text { Lithology description (from } \\
\text { Warren and others, 2003; } \\
\text { Wood, 2007) }\end{array}$ \\
\hline 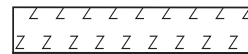 & Nonwelded tuff \\
\hline 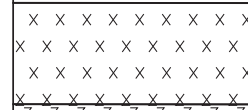 & Welded tuff \\
\hline 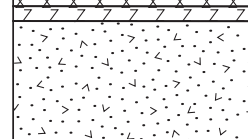 & Nonwelded tuff \\
\hline $\begin{array}{l}z z z z z z z z \\
z z z z z z z z z \\
z z z z z z z z \\
z z z z z z z z z \\
z z z z z z z z \\
z z z z z z z z z\end{array}$ & Nonwelded tuff \\
\hline 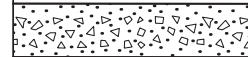 & Flow breccia \\
\hline $\begin{array}{llllllllllllllllll} & z & z & z & z\end{array}$ & Nonwelded tuff \\
\hline 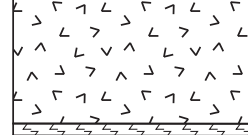 & Lava \\
\hline 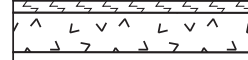 & $\begin{array}{c}\text { Nonwelded tuff } \\
\text { Lava }\end{array}$ \\
\hline 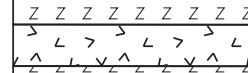 & $\begin{array}{c}\text { Nonwelded tuff } \\
\text { Lava }\end{array}$ \\
\hline 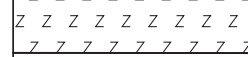 & Nonwelded tuff \\
\hline$x \times x \times x \times x \times x \times$ & Welded tuff \\
\hline 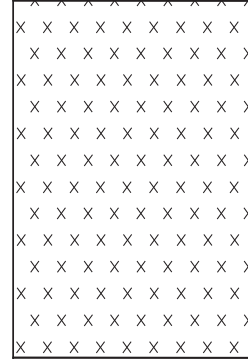 & Nonwelded tuff \\
\hline $\begin{array}{l}z \quad z \quad z \quad z z z z \\
z z z z z z z z z \\
z z z z z z z z \\
z z z z z z z z \\
z z z z z z z \\
z z z z z z z z z \\
z z z z z z z z\end{array}$ & Nonwelded tuff \\
\hline
\end{tabular}

Well-construction diagram (from Fenix \& Scisson, Inc., written commun., 1965)

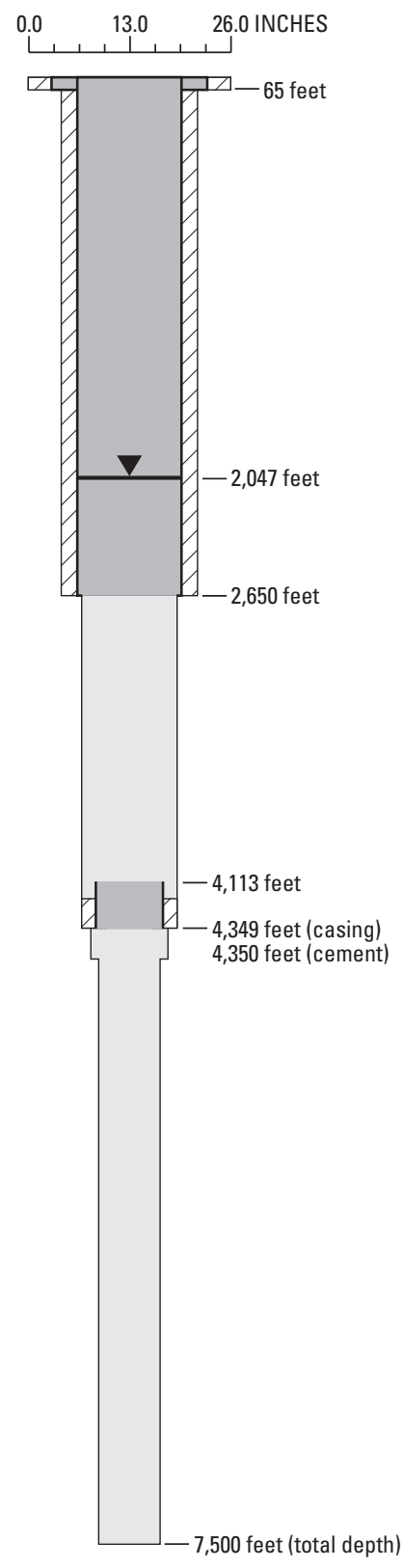

\section{EXPLANATION}

$\square$ Open borehole or annulus $\mathrm{VIT}$ Cement
$\square$ Casing

B

Figure 40.-Continued 

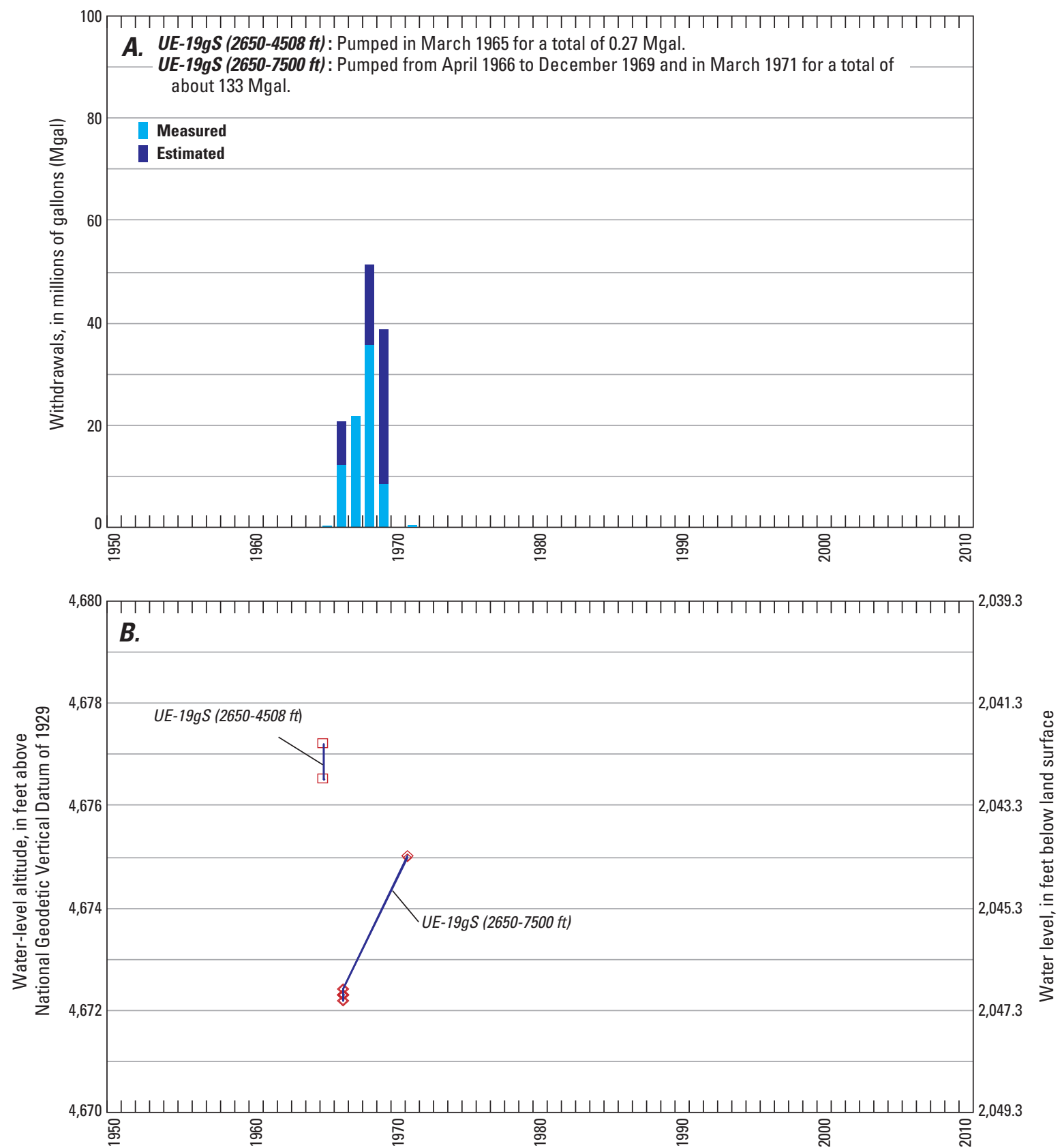

Figure 41. Annual groundwater withdrawals and water levels for wells UE-19gS (2650-4508 ft) and UE-19gS (2650-7500 ft), Area19, Nevada National Security Site, Nye County, Nevada, 1965-75. 
UE-20h WW.-UE-20h WW is on Pahute Mesa in Area 20 of the NNSS (fig. 1; table 1; UE-20h WW photograph not available). Construction information for the borehole was compiled from Fenix \& Scisson, Inc., hole history data (written commun., 1966), and Thordarson and others (1967). The borehole was drilled with the air-rotary method, and completed to a depth of 7,207 ft below land surface in August 1964. Borehole diameter ranges from 26 in. at land surface to $9.88 \mathrm{in}$. at the bottom of the hole $(7,207 \mathrm{ft})$.

Borehole UE-20h WW has one completion interval, well $U E-20 h W W$, which includes casing to a depth of 2,518 ft and an open borehole to 7,207 ft (fig. 42). The lithology at the saturated part of the open interval consists mostly of lava and nonwelded and welded tuffs (fig. 42; Warren and others, 2003). The major zone of water production is in the lava from 4,040 to 4,060 ft (R.K. Blankennagel and others, U.S. Geological Survey, written commun., 1964, p. 39).

UE-20h WW was drilled as an exploratory hole and was used a short time for water supply (Fenix \& Scisson, Inc., written commun., 1966; Thordarson and others, 1967, p. 21). About 22 Mgal of water were withdrawn from well UE-20h WW during a production test in August 1964 and continuous pumping from June to December in 1965 (fig. 43A; appendix A). The well was plugged with cement from 2,265 to 2,514 ft, and recompleted as an emplacement hole in February 1966 for the Rex nuclear test (Fenix \& Scisson, Inc., written commun., 1966; Bechtel Nevada, written commun., 2002).

Water-level measurements made in well UE-20h WW during 1964 and 1965 are shown in figure 43B. The water levels range from about 2,105 to 2,114 ft below land surface. The first two water levels were measured prior to significant pumping of the well, whereas the last two water levels may have been affected by continuous pumping of the well for water supply in 1965, and a $291 / 2$-hour production test during which the well was pumped at an average rate of about $423 \mathrm{gal} / \mathrm{min}$ (J.E. Weir and R.K. Blankennagel, U.S. Geological Survey, written commun., 1966, p. 10). Water levels (not shown in figure 43B) declined about $50 \mathrm{ft}$ during the production test. 


\section{Well name: UE-20h WW}

USGS site identification No.: 371618116260201

Land-surface altitude: 6,557 feet above National Geodetic Vertical Datum of 1929 (NGVD29)

Latitude: $37^{\circ} 16^{\prime} 19^{\prime \prime}$

Longitude: $116^{\circ} 26^{\prime} 02^{\prime \prime}$

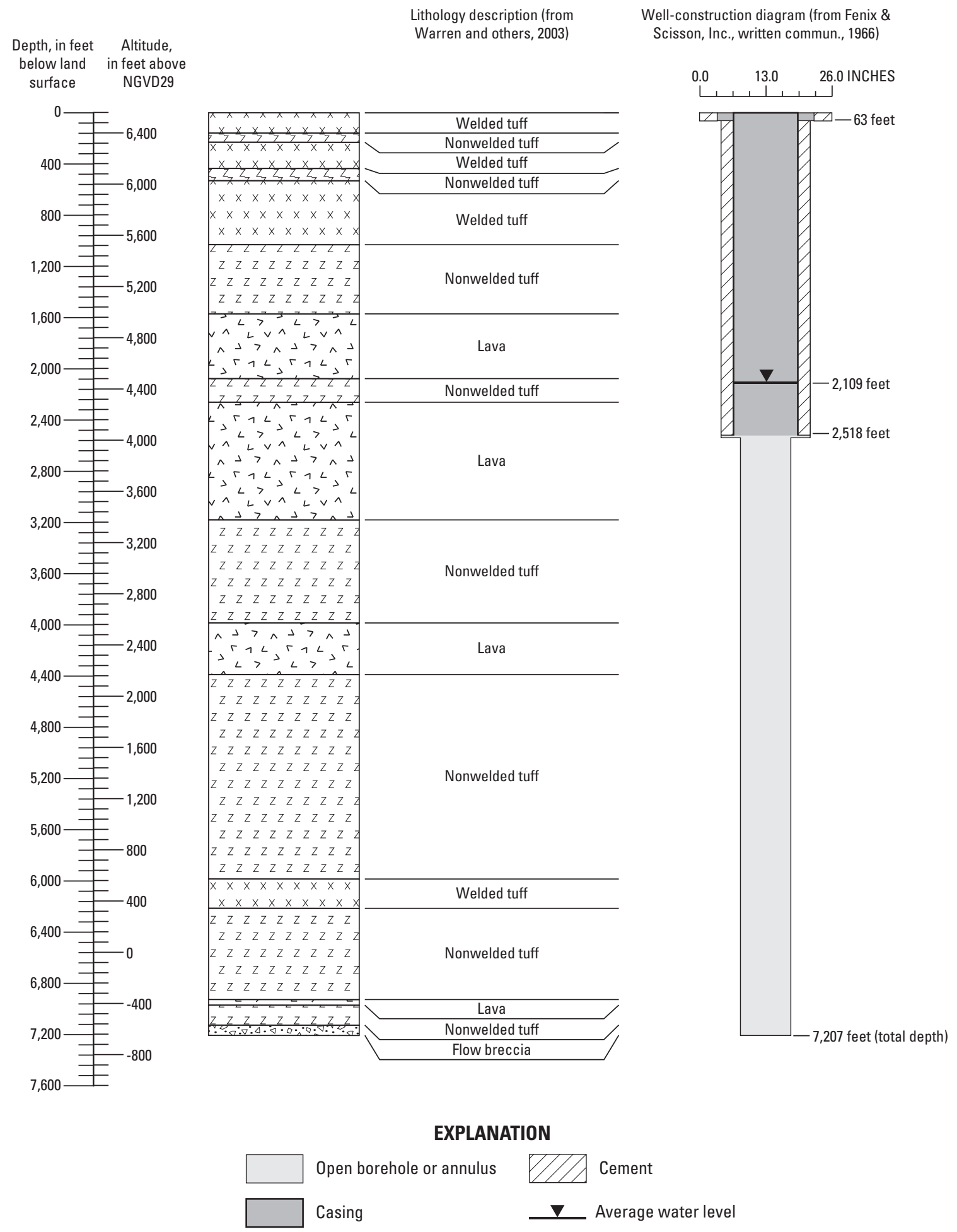

Figure 42. Borehole lithology and well construction for well UE-20h WW, Area 20, Nevada National Security Site, Nye County, Nevada. 

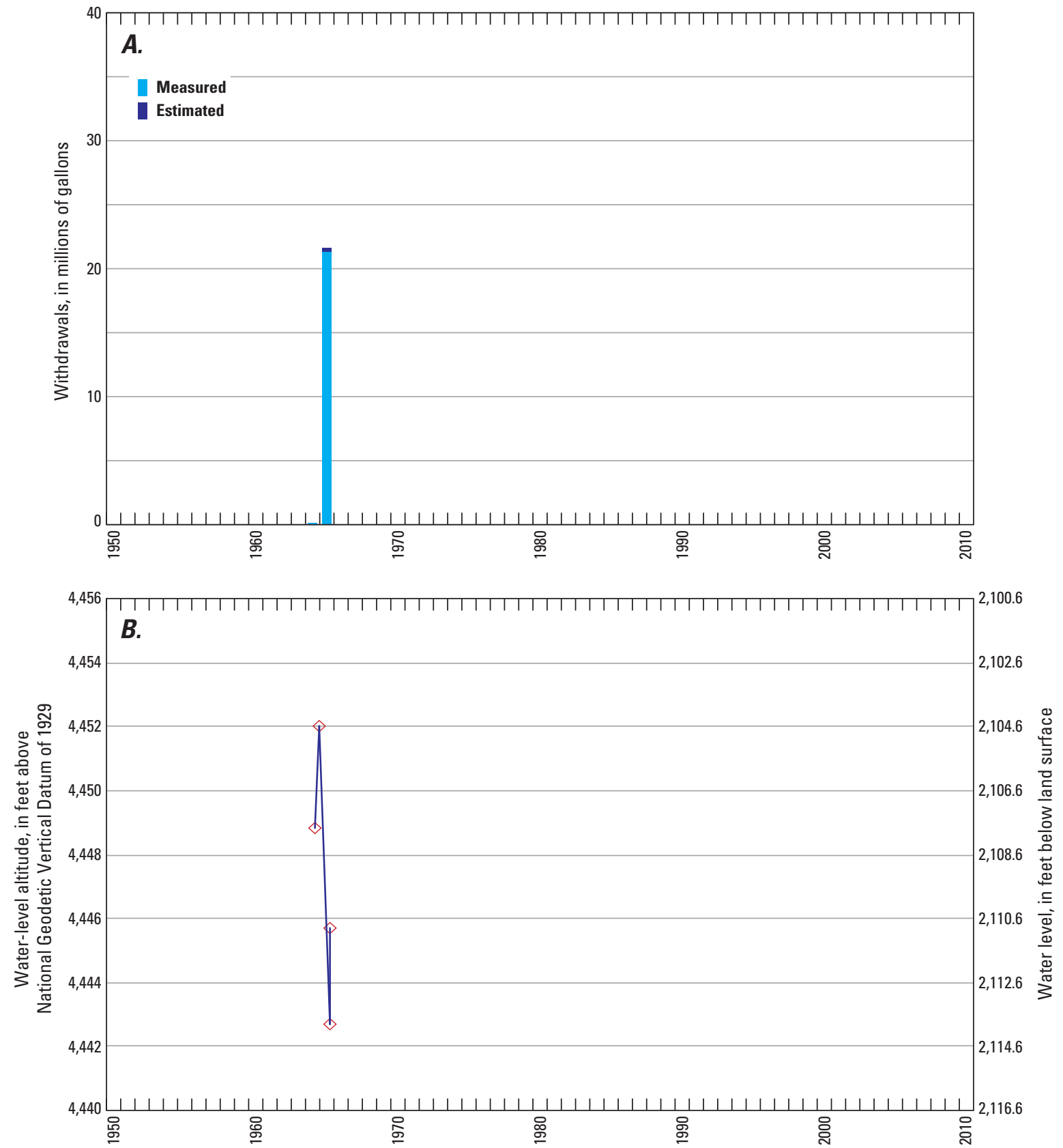

Figure 43. Annual groundwater withdrawals and water levels for well UE-20h WW, Area 20, Nevada National Security Site, Nye County, Nevada, 1964-66. 
UE-20j WW.-UE-20j WW is on Pahute Mesa in Area 20 of the NNSS (fig. 1; table 1; UE-20j WW photograph not available). Construction information for the borehole was compiled from Fenix \& Scisson, Inc., hole history data (written commun., 1965), and Thordarson and others (1967). The borehole was drilled with standard- and air-rotary methods, and completed to a depth of 5,690 ft below land surface in October 1964. Borehole diameter ranges from 26 in. at land surface to $9.88 \mathrm{in}$. at the bottom of the hole (5,690 ft).

Borehole UE-20j WW has one completion interval, well $U E-20 j W W$, which includes casing to a depth of $1,740 \mathrm{ft}$ and an open borehole to 5,690 ft (fig. 44). The lithology at the saturated part of the open interval consists of nonwelded and welded tuffs, volcanic breccias, and lava (fig. 44; Warren and others, 2003; Wood, 2007). Two major water-producing zones were encountered in the hole (Blankennagel and Weir, 1973, table 10). The first, upper zone is from 2,050 to $2,250 \mathrm{ft}$ in densely welded tuff, and the second, lower zone is from 2,960 to 3,830 ft in bedded and welded tuffs (J.W. Hasler, U.S. Geological Survey, written commun., 1965; Blankennagel and Weir, 1973, table 10).
UE-20j WW was drilled as an exploratory hole (J.W. Hasler, U.S. Geological Survey, written commun., 1965; Thordarson and others, 1967, p. 22) and later was used for water supply. More than $58 \mathrm{Mgal}$ of water were withdrawn from well $U E-20 j W W$ during a production test in October 1964 and continuous pumping from May 1967 to November 1969 (fig. 45A; appendix A). The well was instrumented, grouted, and recompleted as an instrument hole in December 1969 (Bechtel Nevada, written commun., 2002).

Water-level measurements made in well UE-20j $W W$ during 1964 are shown in figure 45B. The water levels range from about 1,270 to $1,279 \mathrm{ft}$ below land surface. These measurements were made before and after two production tests in the well (R.K. Blankennagel and J.E. Weir, U.S. Geological Survey, written commun., 1965, p. 26-27). During the production tests, water levels (not shown in figure $45 B$ ) declined as much as $3.5 \mathrm{ft}$ at pumping rates of $100 \mathrm{gal} / \mathrm{min}$, but recovered within a few hours. Water levels measured after the first production test equilibrated at a higher level than previous water levels, possibly because of changing hole conditions (R.K. Blankennagel and J.E. Weir, U.S. Geological Survey, written commun., 1965, p. 27) or measurement error. 
Well name: UE-20j WW

USGS site identification No.: 371801116320301

Land-surface altitude: 5,903 feet above National Geodetic Vertical Datum of 1929 (NGVD29)

Latitude: $37^{\circ} 18^{\prime} 01^{\prime \prime}$

Longitude: $116^{\circ} 32^{\prime} 03^{\prime \prime}$

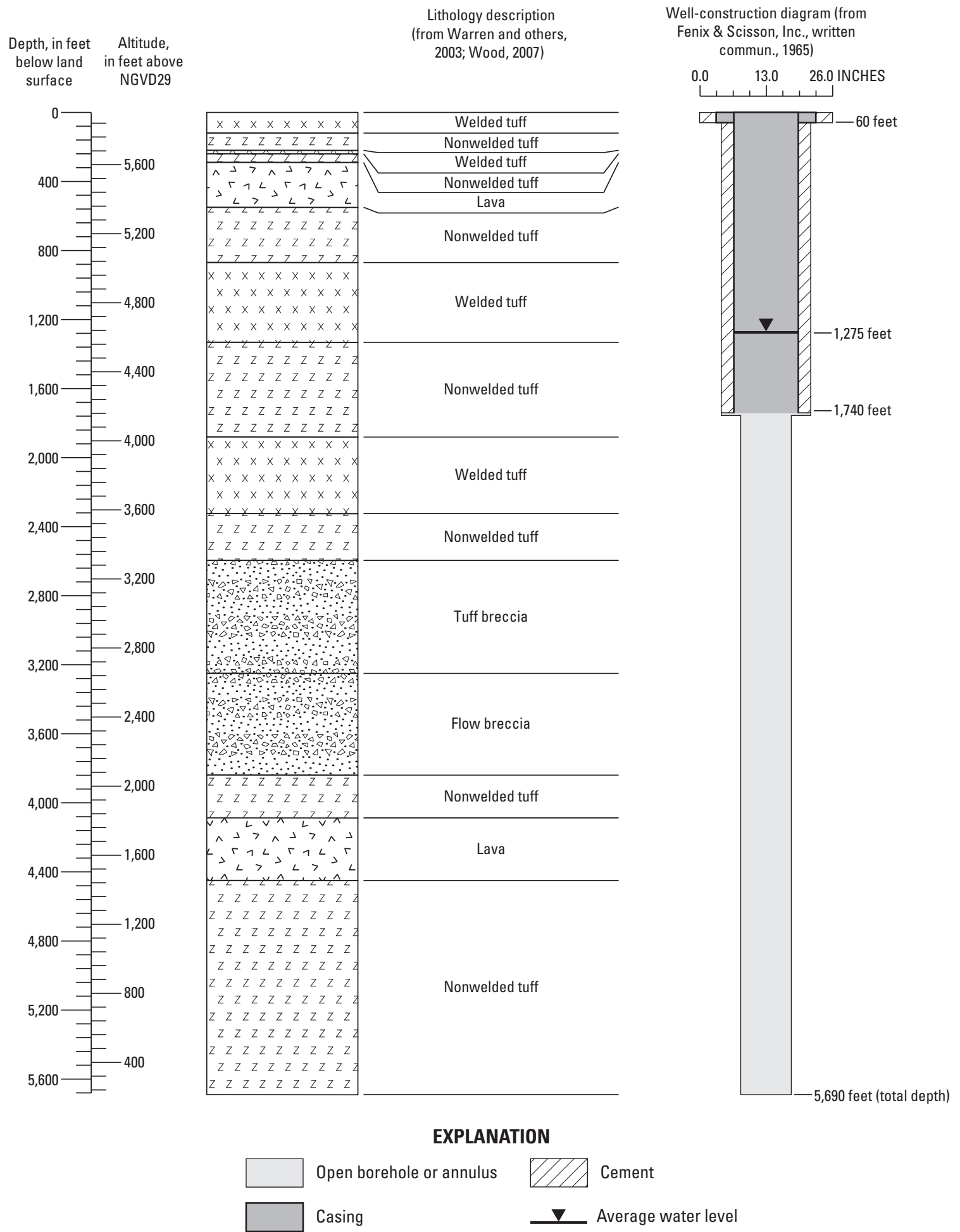

Figure 44. Borehole lithology and well construction for well UE-20j WW, Area 20, Nevada National Security Site, Nye County, Nevada. 

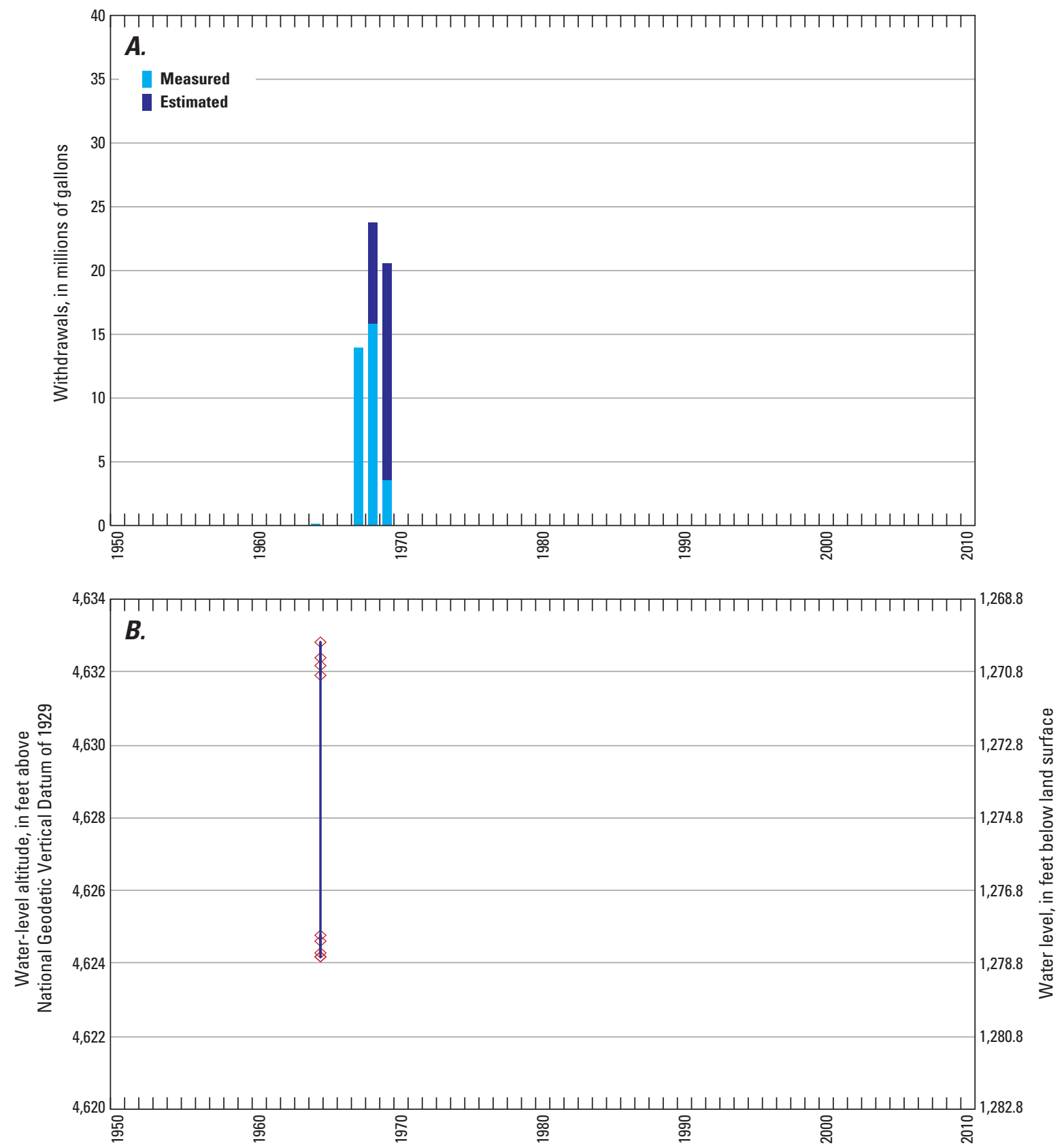

Figure 45. Annual groundwater withdrawals and water levels for well UE-20jWW, Area 20, Nevada National Security Site, Nye County, Nevada, 1964-69. 
UE-25c 3. - UE-25c 3 is on the west side of Area 25 of the NNSS (fig. 1; table 1; UE-25c3 photograph). Construction information for the borehole was compiled from Geldon (1993, 1996). The borehole was rotary drilled and completed to a depth of 3,000 ft below land surface in April 1984 (Geldon, 1993, p. 5; 1996, p. 2). Borehole diameter ranges from $48 \mathrm{in}$. at land surface to $9.88 \mathrm{in}$. at the bottom of the hole.

Borehole UE-25c 3 has three completion intervals, well $U E-25 c$ 3, well $U E-25 c 3$ (2286-2879 ft), and well $U E-25 c 3$ (2285-2667 ft). Well UE-25c 3 represents the borehole as it was completed in April 1984 with no packers (fig. 46A). This first completion includes casing to a depth of $1,323 \mathrm{ft}$ and an open borehole to $3,000 \mathrm{ft}$. The lithology at the saturated part of the open interval consists of alternating layers of nonwelded and welded tuffs, and tuff breccia (fig. 46A; Geldon, 1993, p.35).

Since 1985, multiple packers have been installed in the borehole for various hydraulic tests (Geldon, 1996; Geldon and others, 1998, 2002). The packers are suspended on tubing that includes a slotted well screen; the depth of the screen is unknown and therefore is estimated in figures 46B-46C. Well UE-25c 3 (2286-2879 ft) represents the hole from August 1995 to April 1996 when two of five packers installed in the borehole were used to isolate the depth interval from 2,286 to $2,879 \mathrm{ft}$ (fig. 46B). The lithology at the saturated part of the open interval consists of welded and nonwelded tuffs, and tuff breccia (Geldon, 1993, p.35).

Well UE-25c 3 (2285-2667 ft) represents the hole from April 1996 to June 1999 when two of three packers installed in the borehole were used to isolate the depth interval from 2,285 to 2,667 ft (fig. 46C). The lithology at the saturated part of the open interval consists of welded and nonwelded tuffs (Geldon, 1993, p.35).

The borehole is open to six hydrogeologic intervals between about 1,400 and 3,000 ft that are described in detail by Geldon (1996), and Geldon and others (2002). The most permeable zone is in the welded tuff at about 2,400 ft below land surface (Geldon and others, 2002, p. 19).

UE-25c 3 was drilled to obtain a better understanding of the hydraulic characteristics of fractured rocks near Yucca Mountain (Robison and others, 1988, p. 79). Hydraulic properties of the hydrogeologic intervals encountered in the borehole were determined from a series of production tests in UE-25c 3 from 1984 to 1997 (Geldon , 1996; Geldon and others, 1998, 2002). More than $147 \mathrm{Mgal}$ of water were withdrawn from the borehole during these tests (fig. 47A; appendix A). Production tests were done in well $U E-25 c 3$ in May 1984, October-November 1984, and May-June 1995 for a total of about $22 \mathrm{Mgal}$ of water withdrawn from the well.
Well Ue-25c 3 (2286-2879 ft) was pumped in November 1995 and January-March 1996 for a total of about 9 Mgal of water withdrawn from the well. Well UE-25c 3 (2285-2667 ft) was pumped for a production test from May 1996 to November 1997 for a total of $116 \mathrm{Mgal}$ of water withdrawn from the well.

Periodic water-level measurements made in UE-25c 3 from 1984 to 1999 are shown in figure 47B. The water levels in well $U E-25 c 3$ range from about 1,318 to 1,319 ft below land surface. Water levels in well UE-25c 3 (2285-2667 ft) are about $1,318 \mathrm{ft}$ below land surface. No known water levels were measured in well $U E-25 c 3$ (2286-2879 ft). Water levels represent pre- or post-pumping conditions in the aquifer because they were measured prior to or days-to-months after pumping occurred.

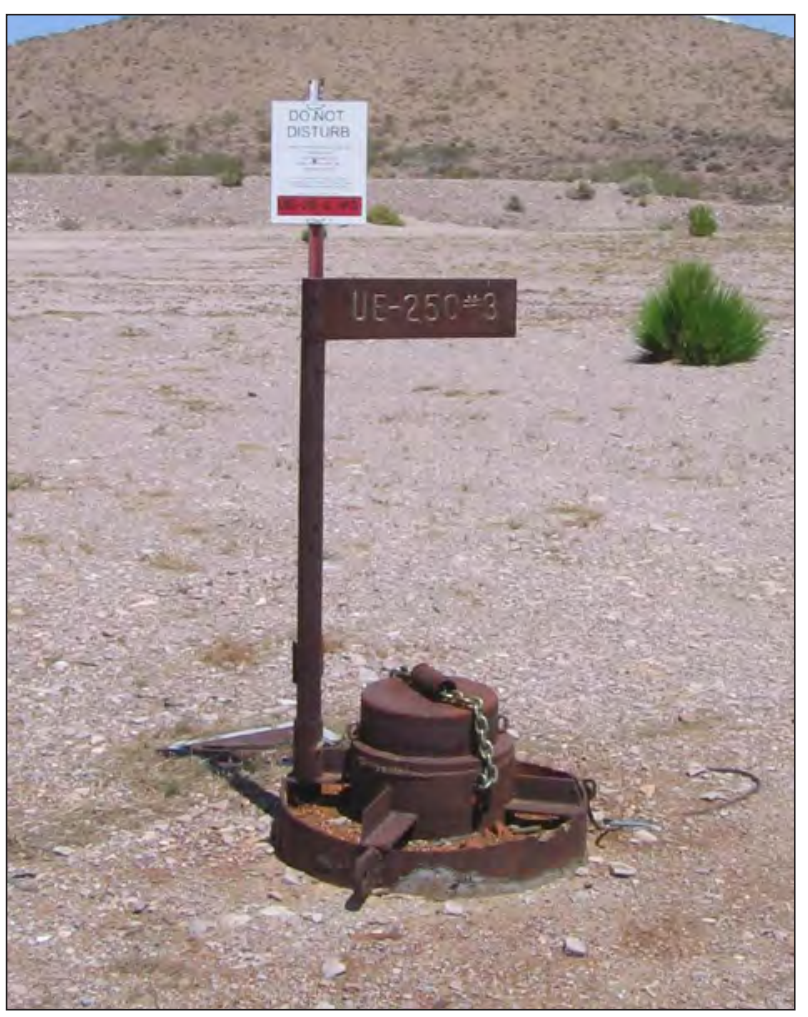

UE-25c 3, June 2009. Photograph courtesy of U.S. Department of Energy. 


\section{Well name: UE-25c 3}

USGS site identification No.: 364947116254501

Land-surface altitude: 3,714 feet above National Geodetic Vertical Datum of 1929 (NGVD29)

Latitude: $36^{\circ} 49^{\prime} 45^{\prime \prime}$

Longitude: $116^{\circ} 25^{\prime} 44^{\prime \prime}$

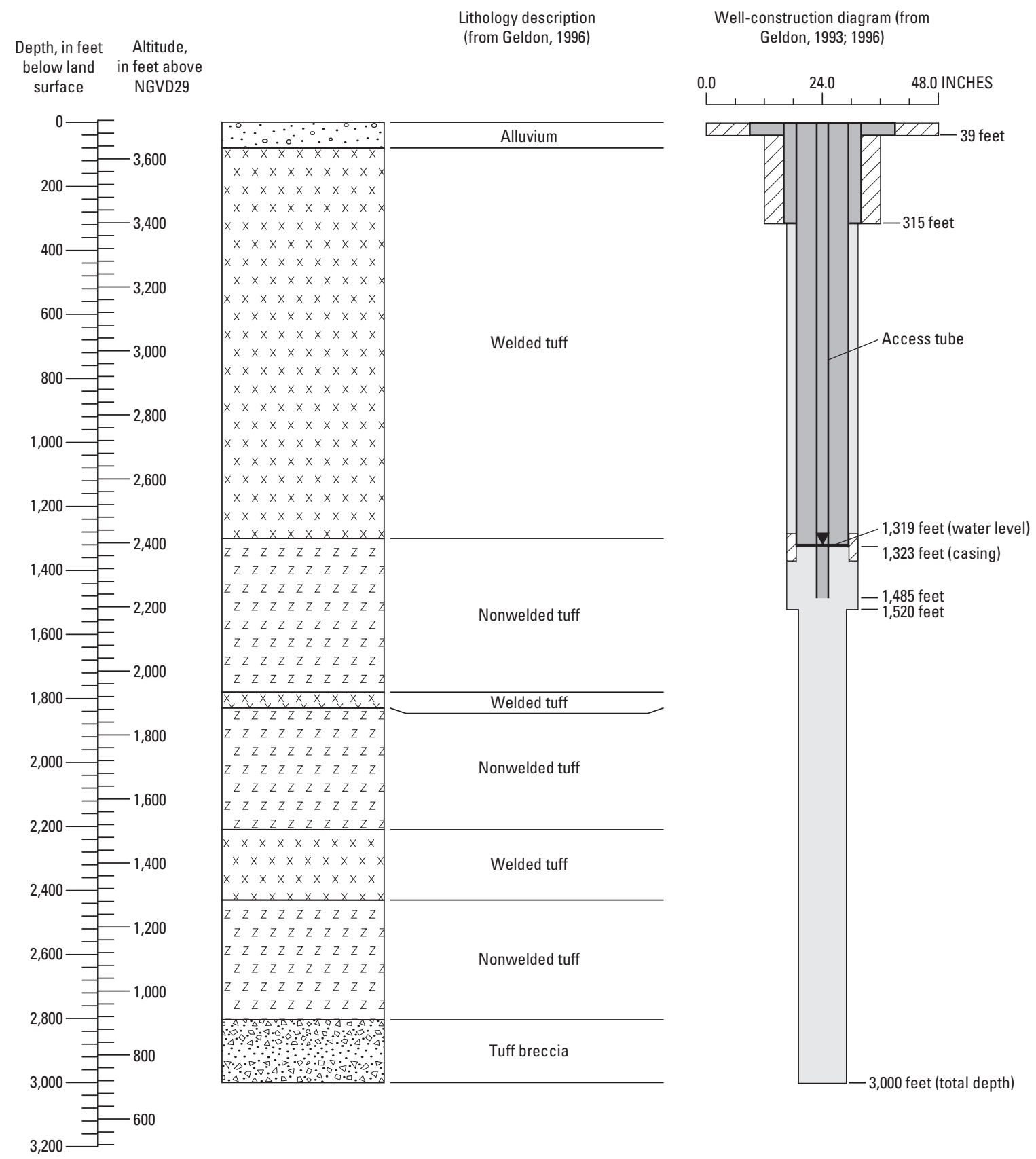

EXPLANATION

$\boldsymbol{A}$

Open borehole or annulus
Casing

Figure 46. Borehole lithology and well construction for wells UE-25c 3, Ue-25c 3 (2286-2879 ft), and UE-25c 3 (2285-2667 ft), Area 25, Nevada National Security Site, Nye County, Nevada. 
Well name: UE-25c 3 (2286-2879 ft)

USGS site identification No.: 364947116254504

Land-surface altitude: 3,714 feet above National Geodetic Vertical Datum of 1929 (NGVD29)

Latitude: $36^{\circ} 49^{\prime} 45^{\prime \prime}$

Longitude: $116^{\circ} 25^{\prime} 44^{\prime \prime}$

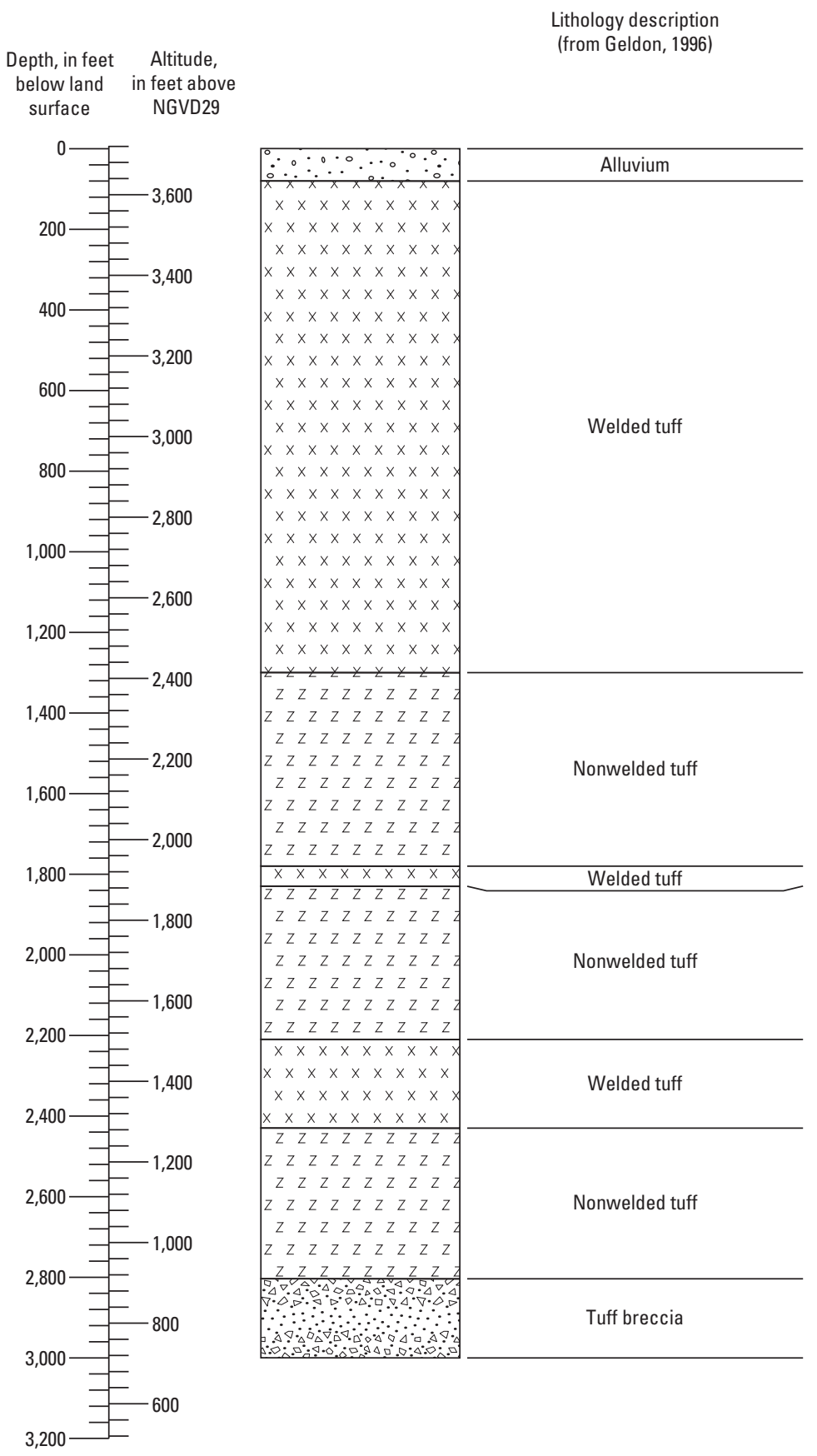

\section{EXPLANATION}

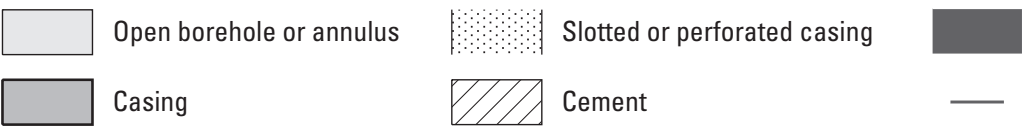

Inflated packer

Estimated water level

$\boldsymbol{B}$

Figure 46.-Continued
Well-construction diagram (from Geldon, 1993; 1996

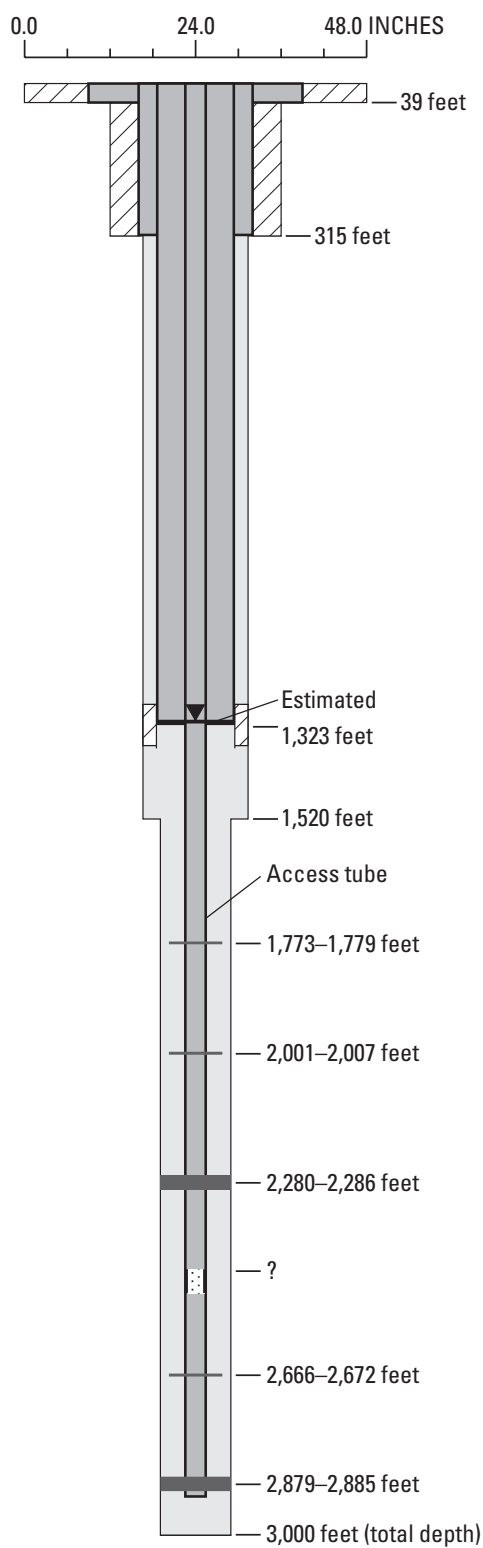


Well name: UE-25c 3 (2285-2667 ft)

USGS site identification No.: 364947116254505

Land-surface altitude: 3,714 feet above National Geodetic Vertical Datum of 1929 (NGVD29)

Latitude: $36^{\circ} 49^{\prime} 45^{\prime \prime}$

Longitude: $116^{\circ} 25^{\prime} 44^{\prime \prime}$

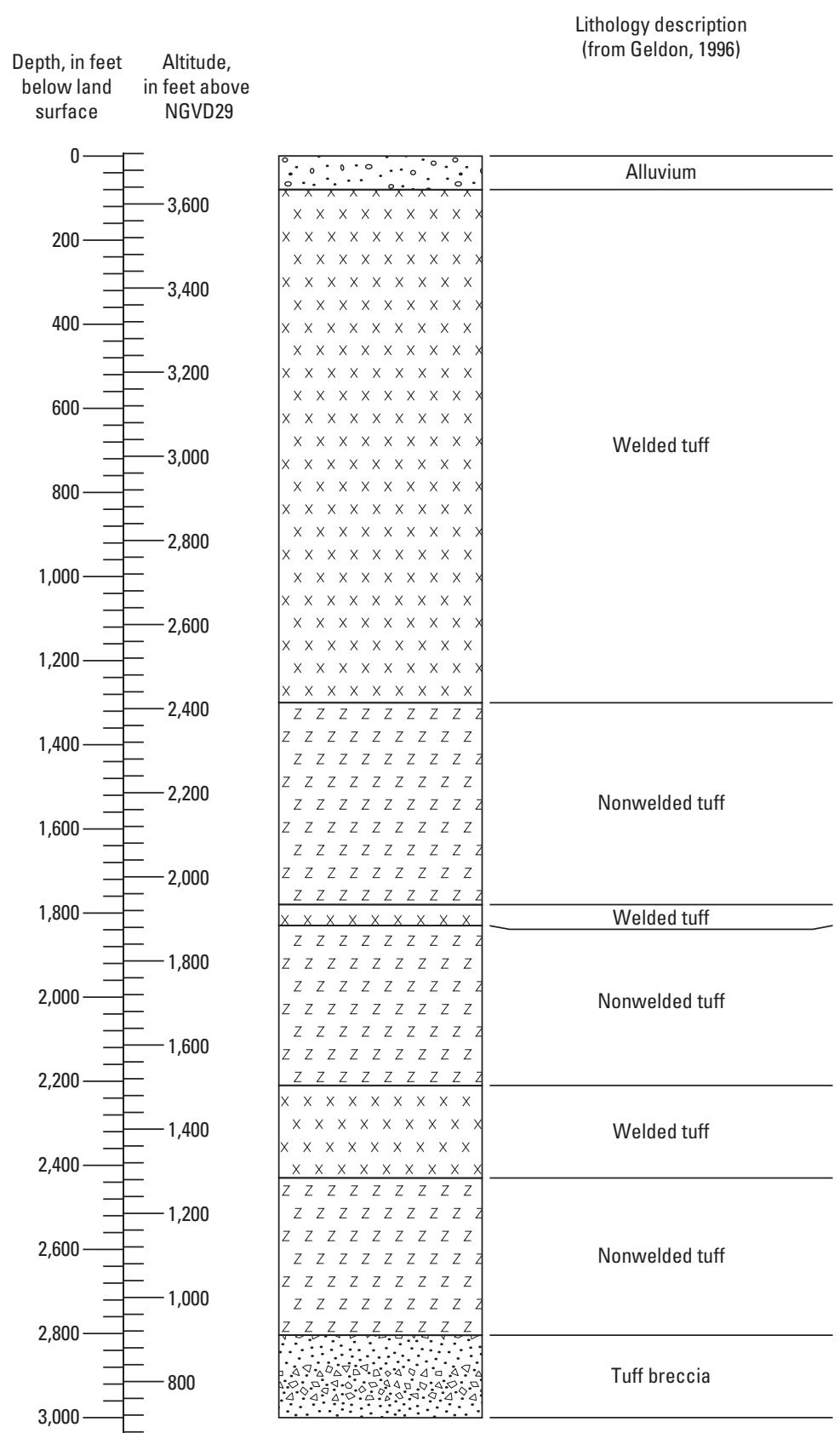

Well-construction diagram (from Geldon, 1993; 1996)

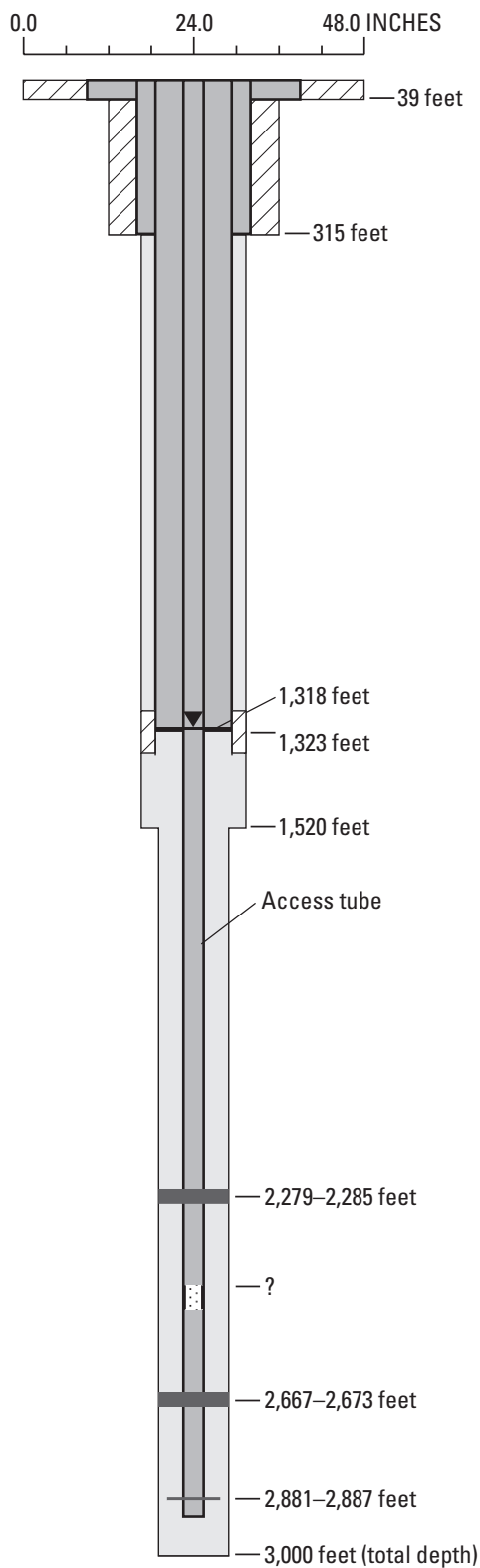

\section{EXPLANATION}
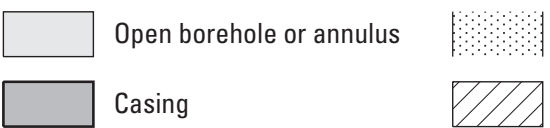

Slotted or perforated casing

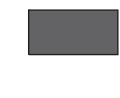

Inflated packer

$\nabla \quad$ Average water level

C

Cement

Deflated packer

Figure 46.-Continued 

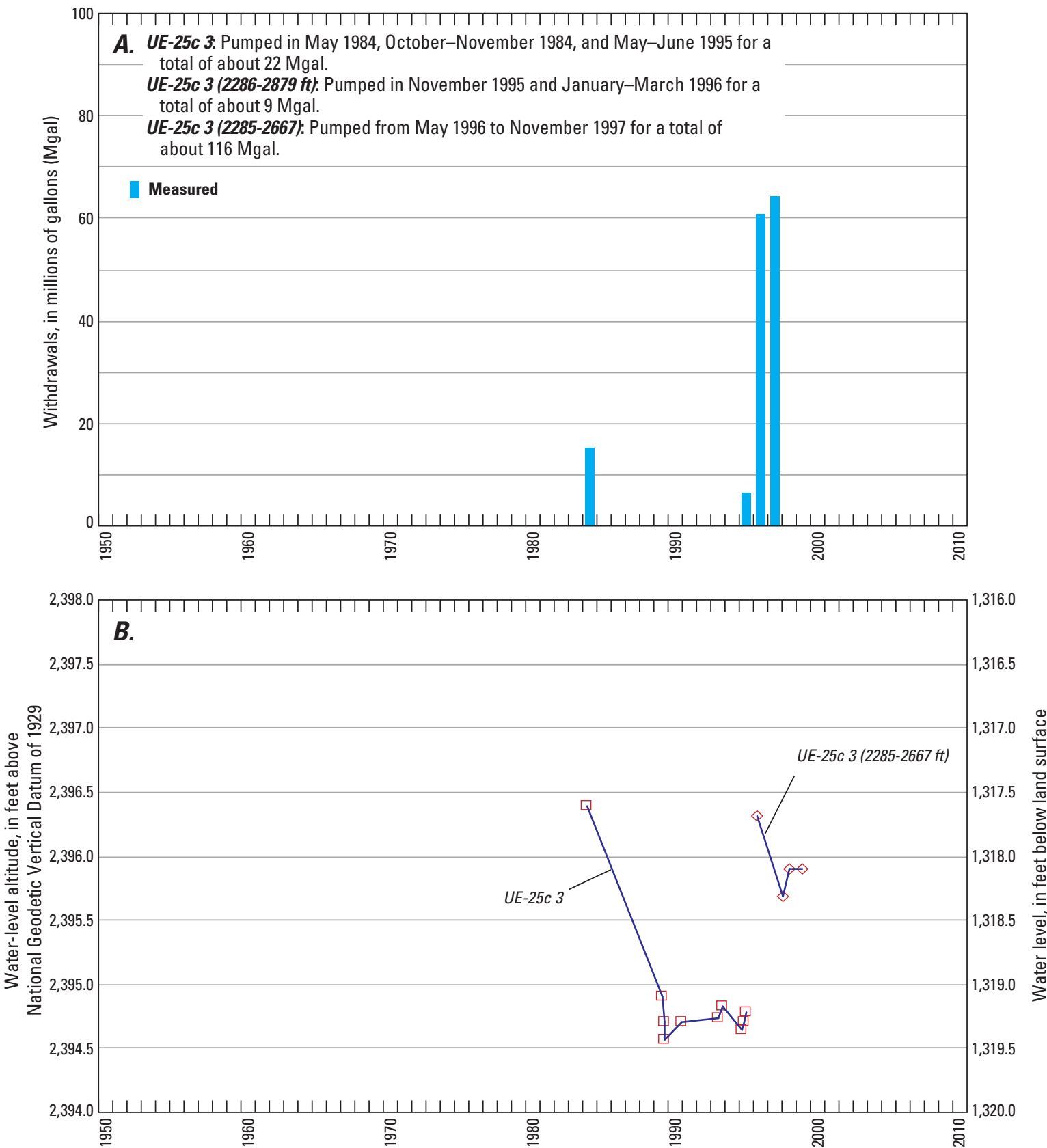

Figure 47. Annual groundwater withdrawals and water levels for wells UE-25c 3, UE-25c 3 (22862879), and UE-25c 3 (2285-2667), Area 25, Nevada National Security Site, Nye County, Nevada, 1984-99. 
WW-1.-WW-1 is in Frenchman Flat about 1 mile east of the Area 5 boundary of the NNSS (fig. 1; table 1; WW-1 photograph). Construction information for the borehole was compiled from S.R. McKinney \& Son (written commun., 1950), U.S. Army Corps of Engineers (1951), and Moore (1962). The borehole was drilled and completed to a depth of $870 \mathrm{ft}$ below land surface in December 1950 using the cabletool method. Borehole diameter ranges from 12 in. at land surface to $8 \mathrm{in}$. at the bottom of the hole.

Borehole WW-1 has a single completion interval, well $W W-1$, which includes casing to a depth of $802 \mathrm{ft}$ and an open borehole to $870 \mathrm{ft}$ (fig. 48). The casing is perforated from 602 to $802 \mathrm{ft}$. Information regarding a cement seal at the top of the hole is not available; therefore, the interval of cement shown in figure 48 is estimated, and the annular space between the casing and the borehole could be open below about $25 \mathrm{ft}$. The lithology at the saturated part of the open interval is alluvium consisting of alternating layers of silty sand and fine to coarse gravels that are partly cemented at the bottom of the hole (fig. 48; U.S. Army Corps of Engineers, 1951). The major water-bearing formation is the cemented gravels from 714 to $870 \mathrm{ft}$ (S.R. McKinney \& Son, written commun., 1950).

The intended use of well $W W-1$ was for water supply of U.S. Atomic Energy Commission activities at the NNSS, but the well was abandoned after an unsuccessful attempt to increase the yield (Moore, 1962, p. 36). The well later was used for water supply from 1964 to 1967 during which more than 112 Mgal of water were withdrawn from the well (fig. 49A; appendix A). The well was reported as destroyed by Thordarson and others (1967, p. 15) and was determined to be obstructed at a depth of about $31 \mathrm{ft}$ below land surface in 2001.

One water level was measured in well $W W-1$ on the day the well was completed in 1950 (fig. 49B); the water level is at a depth of $714 \mathrm{ft}$ below land surface. A 28-hour production test was done in the well about 2 weeks after the well was completed. During this test, the well was pumped at a rate of $55 \mathrm{gal} / \mathrm{min}$ resulting in $38 \mathrm{ft}$ of drawdown.

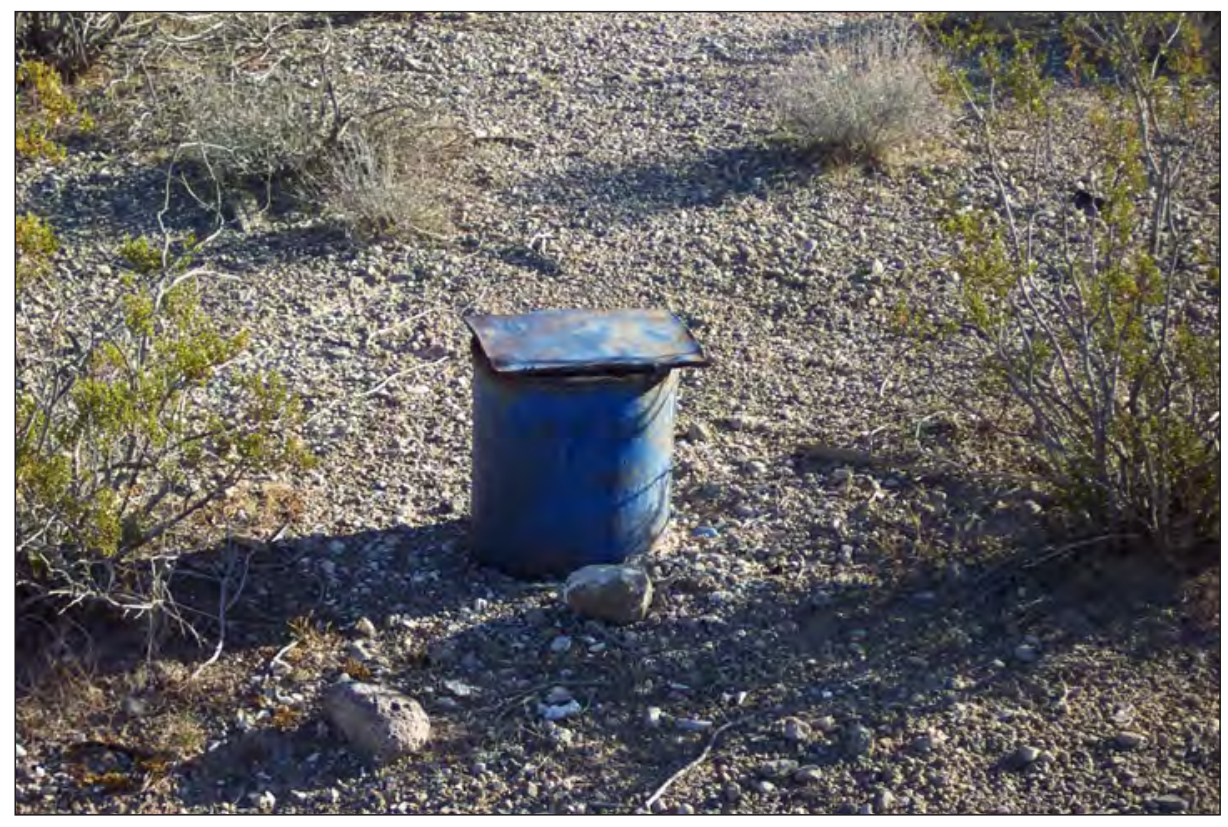

WW- 1, August 2009. Photograph by Terry L. Miller, U.S. Geological Survey. 
Well name: $W W-1$

USGS site identification No.: 364844115541301

Land-surface altitude: 3,100 feet above National Geodetic Vertical Datum of 1929 (NGVD29)

Latitude: $36^{\circ} 48^{\prime} 44^{\prime \prime}$

Longitude: $115^{\circ} 54^{\prime} 13^{\prime \prime}$

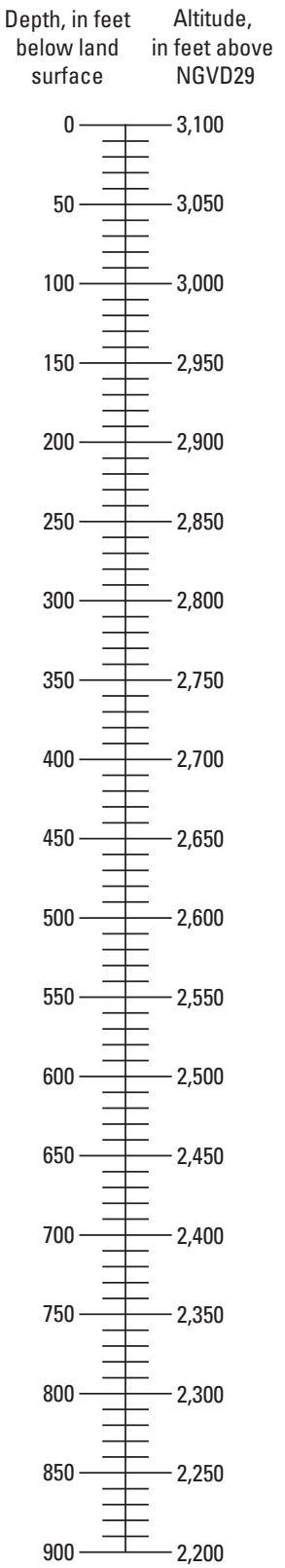

Lithology description (from Wood, 2007)
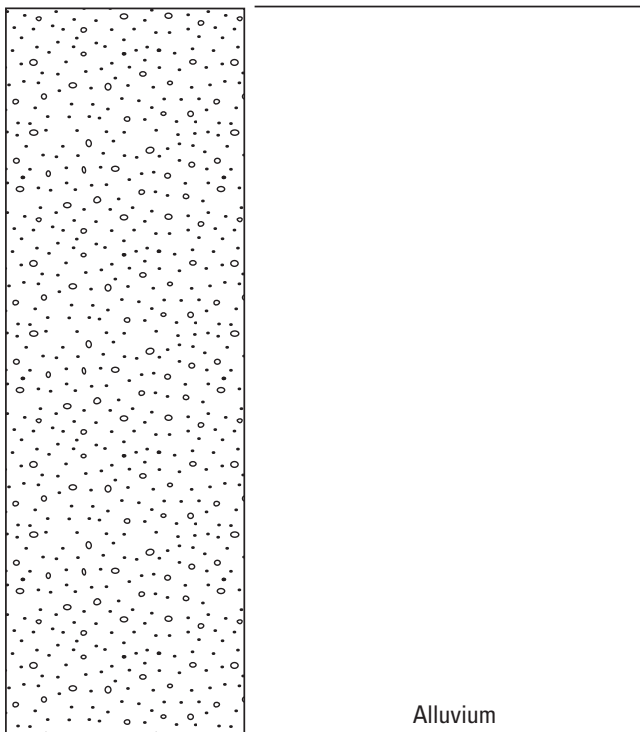

$\because \because \because \because \cdots$
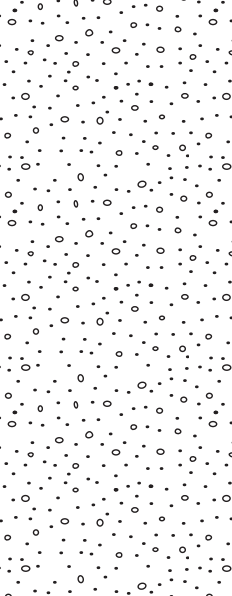

$\therefore \therefore \therefore \circ \circ$

$\circ \circ \cdot 0.0$
Well-construction diagram (from S.R. McKinney \& Son, written commun., 1950; U.S. Army Corps of Engineers, 1951; Moore, 1962)
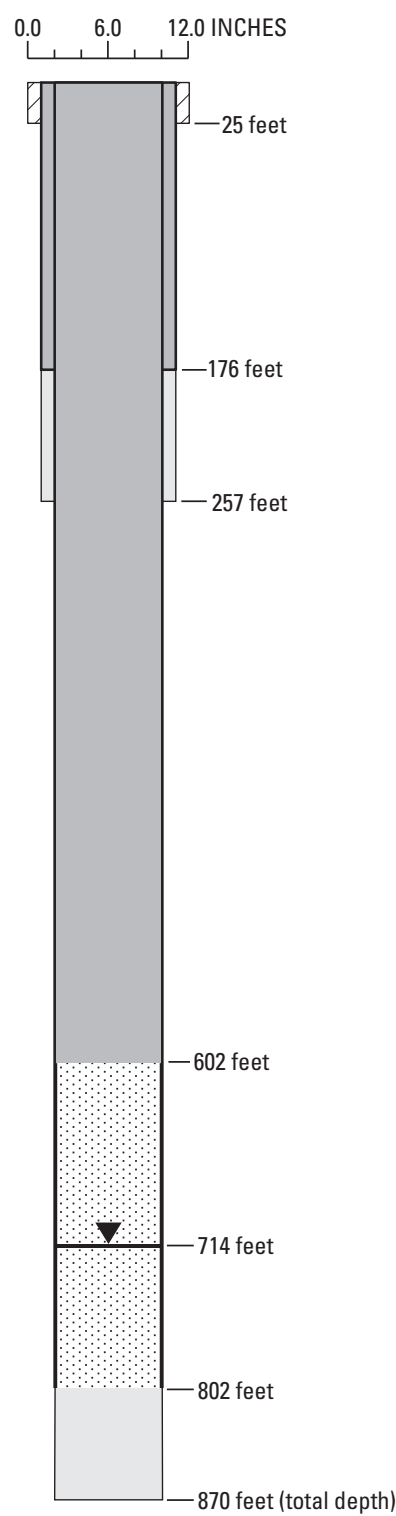

\section{EXPLANATION}

Slotted or perforated casing

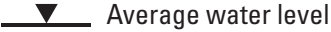

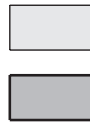

Open borehole or annulus

Casing

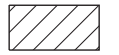

Cement, exact thickness not known

Figure 48. Borehole lithology and well construction for well $W W$-1, located outside Nevada National Security Site near eastern boundary of Area 5, Nye County, Nevada. 

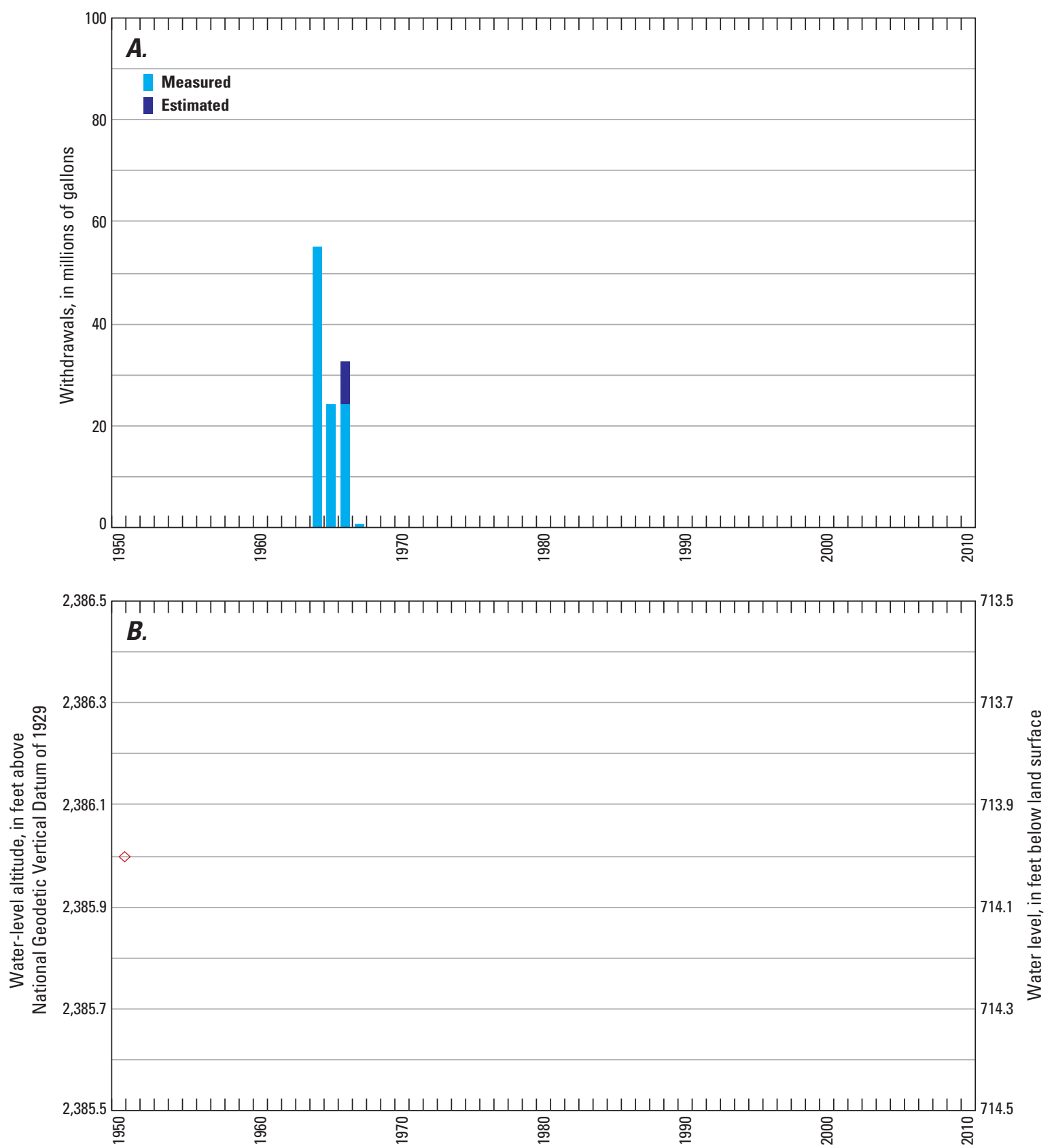

Figure 49. Annual groundwater withdrawals and water levels for well $W W-1$, located outside Nevada National Security Site near eastern boundary of Area 5, Nye County, Nevada, 1950-67. 
WW-2.-WW-2 is in northern Yucca Flat in Area 2 of the NNSS (fig. 1; table 1; WW-2 photograph). Construction information for the borehole was compiled from Moore and others (1963). The borehole was drilled to a depth of 2,535 ft below land surface in June 1961, and was deepened to a total depth of 3,422 ft in March 1962. The borehole was drilled using the hydraulic-rotary and cable-tool methods. During drilling, the borehole deviated slightly from vertical; at a measured hole depth of 3,300 ft, the true vertical depth is 3,299.21 ft. Measured (slant) depths are used when referring to well WW-2, except for water levels, which are reported as true vertical depths. Borehole diameter ranges from 16 in. at land surface to $7.88 \mathrm{in}$. at the bottom of the hole.

Borehole WW-2 has one completion interval, well $W W-2$ (3422 ft), which includes casing to a depth of 3,422 ft, with two perforated zones from 2,700 to 2,950 ft and 3,164 to 3,412 ft (fig. 50). The casing and cement were gun perforated from 2,700 to 2,950 ft (Moore and others, 1963, p. 40). The annular space between the casing and borehole is open from 2,940 to 3,034 ft and 3,176 to 3,422 ft. The lithology at the saturated part of the open interval consists of Paleozoic dolomite interbedded with limestone, shale and argillite (fig. 50; Wood, 2007). The primary water-producing zone is in the fractured carbonate rocks from a depth of 3,095 to 3,422 (Moore and others, 1963, p. 29).

WW-2 was drilled specifically to obtain hydrologic data for determining the direction and rate of groundwater movement beneath the NNSS (Moore and others, 1963, p. 3). Upon completion, well $W W-2$ (3422 ft) was used as a source of water for construction activities in Area 2 (Russell, 1989, p. 24). The well also was part of the DOE hydrologic monitoring network from 1973 to 2006 (Russell, 1989; Bechtel Nevada, 2003; U.S. Department of Energy, 2008, p. 7-6). More than 1,030 Mgal of water were withdrawn from the well from 1962 to 1990 (igg. 51A; appendix A). No known withdrawals have occurred since 1990, with the exception of purging activities associated with groundwater sampling in September 2006 (Stoller-Navarro Joint Venture, written commun., 2007).

Periodic water-level measurements made in well $W W-2$ (3422 ft) since 1962 are shown in figure 51B. The water levels range from about 2,051 to 2,056 ft below land surface. With the exception of one measurement, water levels in the well represent pre- or post-pumping conditions within the aquifer. The water level in 1969 shows the effects of pumping in the well.

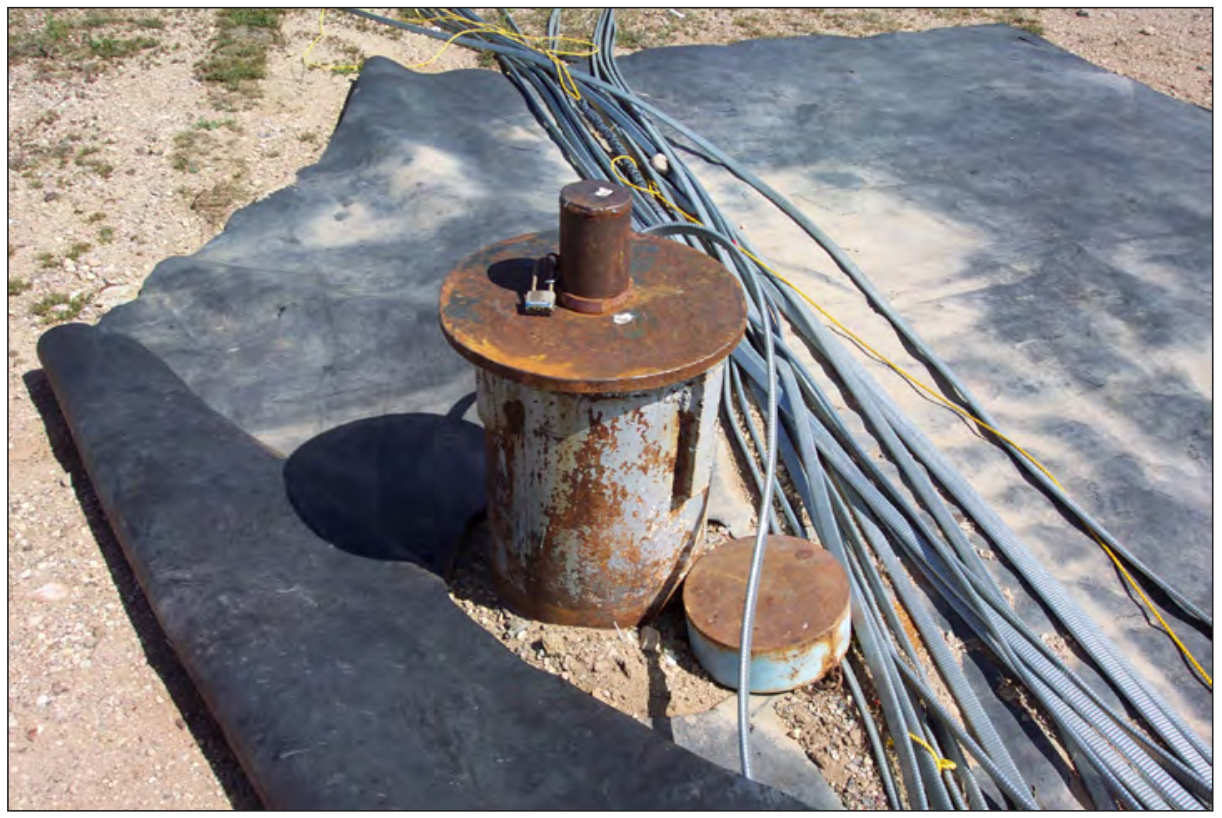

WW- 2, April 2009. Photograph by Terry L. Miller, U.S. Geological Survey. 
Well name: $W W-2(3422 \mathrm{ft})$

USGS site identification No.: 370958116051512

Land-surface altitude: 4,470 feet above National Geodetic Vertical Datum of 1929 (NGVD29)

Latitude:-

Longitude:-

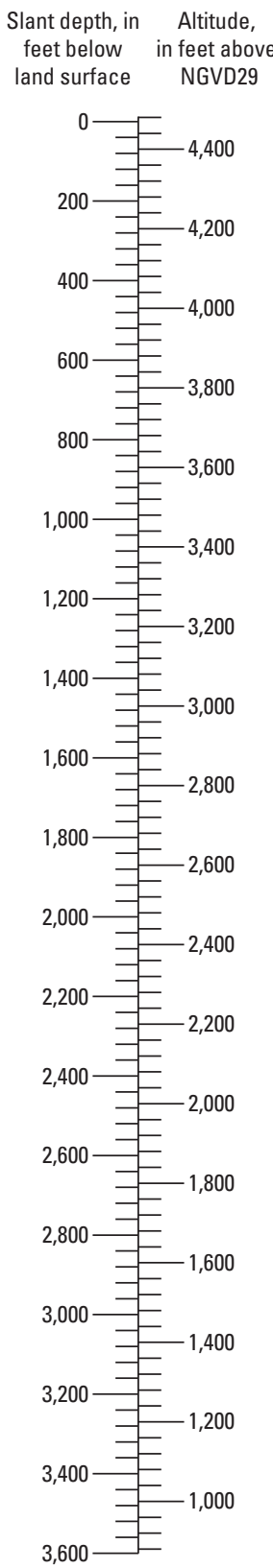

Lithology description

(from Wood, 2007)

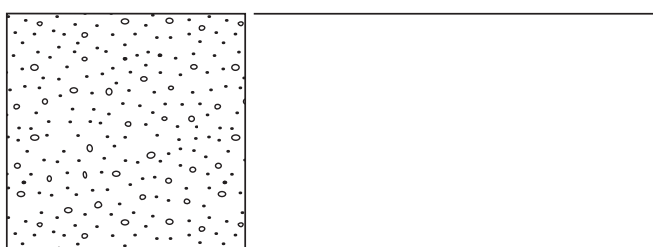

Alluvium

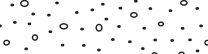

$\therefore \quad \therefore \quad \therefore \because$

$\therefore \therefore \therefore \circ$

$\because \because \because \because \therefore \therefore$

$\because \therefore \circ \div 0$

z z Z Z Z Z Z Z Z

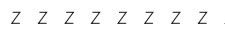

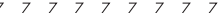

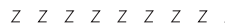

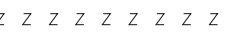

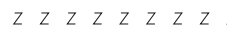

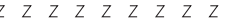

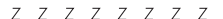

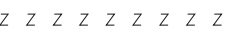

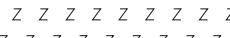

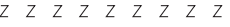

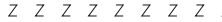

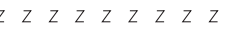

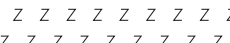

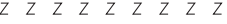

$\begin{array}{lllllllll}z & z & Z & z & Z & Z & Z & Z\end{array}$

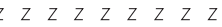

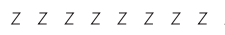

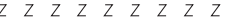

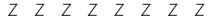

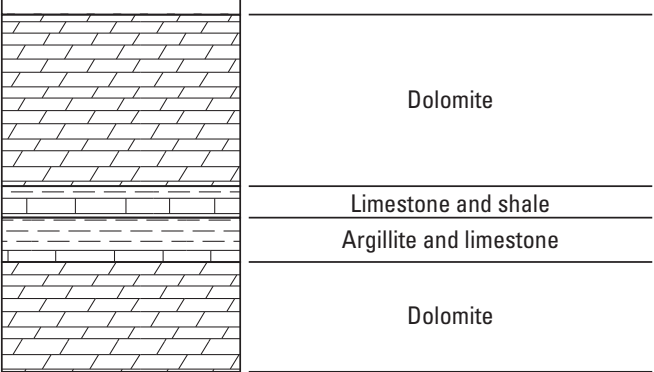

Nonwelded tuff
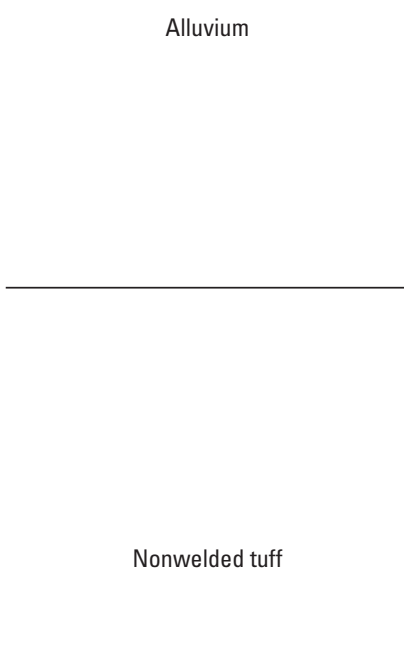

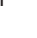



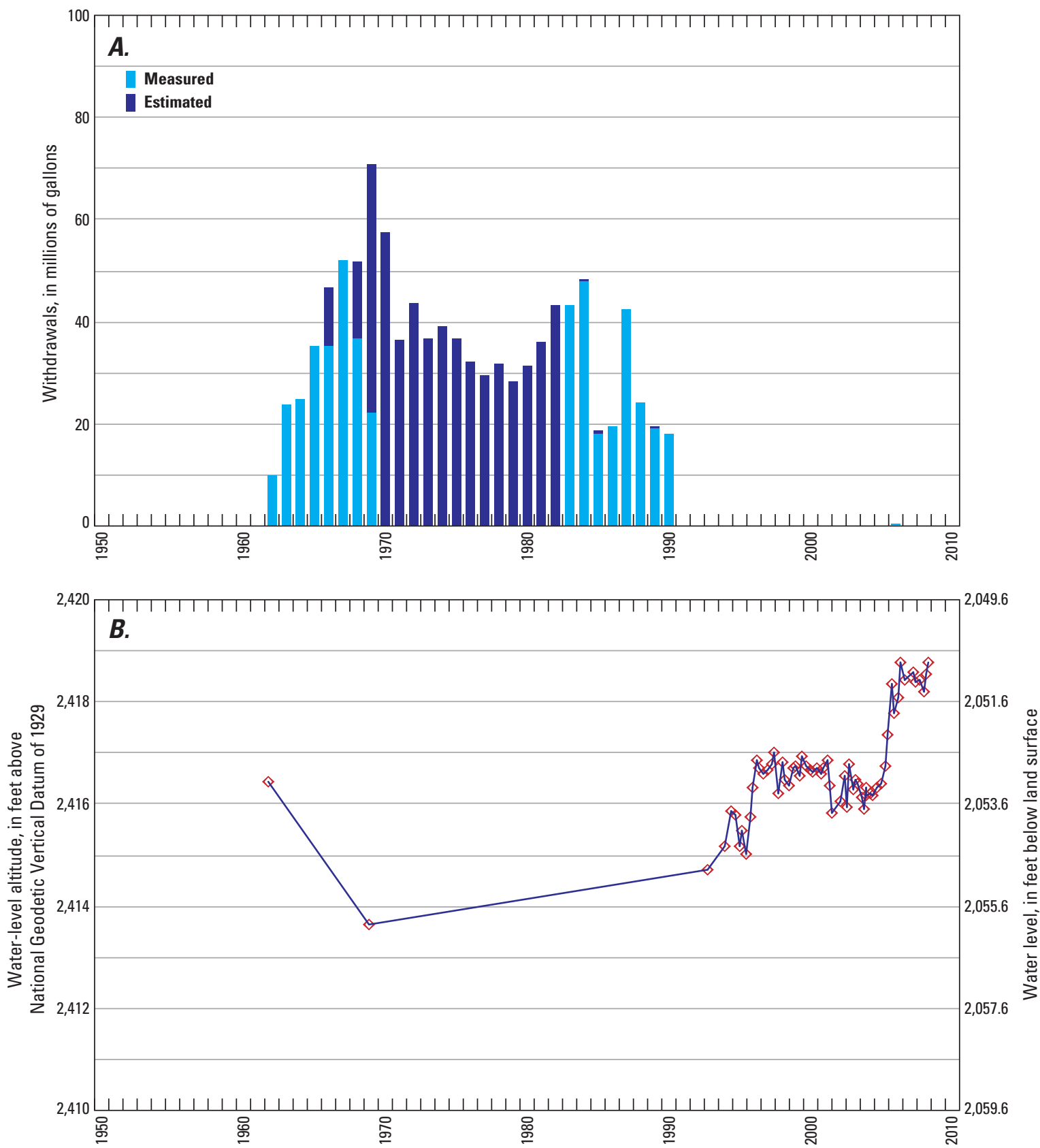

Figure 51. Annual groundwater withdrawals and water levels for well WW-2 (3422 ft), Area 2, Nevada National Security Site, Nye County, Nevada, 1962-2008. 
WW-3.-WW-3 is in southern Yucca Flat in Area 6 of the NNSS (fig. 1; table 1; WW-3 photograph). Construction information for the borehole was compiled from Raytheon Services Nevada hole history data (written commun., no date), S.R. McKinney \& Son (written commun., 1951, 1952), and Moore (1961). The borehole was drilled to a depth of $1,575 \mathrm{ft}$ below land surface in February 1951, and then deepened to a total depth of 1,800 ft and completed as a water-supply well in March 1952. The borehole was drilled using the cable-tool method. Borehole diameter ranges from at least $12 \mathrm{in}$. at land surface to $8 \mathrm{in}$. at the bottom of the hole.

Borehole WW-3 has one completion interval, well $W W-3$ (1800 ft), which includes casing to a depth of $1,765 \mathrm{ft}$ and an open borehole to $1,800 \mathrm{ft}$ (fig. 52). The casing is slotted from 1,535 to $1,765 \mathrm{ft}$, and the annular space between the casing and borehole is open below at least a depth of $1,209 \mathrm{ft}$. Information on cement in the well annulus is not available; therefore, the intervals of cement shown in figure 52 are estimated. The lithology at the saturated part of the open interval consists of nonwelded tuff, sandstone, and conglomerate (fig. 52; Wood, 2007). When the borehole was
$1,575 \mathrm{ft}$ deep, the water-bearing unit was the tuff (Wilmarth and others, 1959, p. 36). After the borehole was deepened to $1,800 \mathrm{ft}$, the principle water-bearing unit became the sandstone from 1,685 to 1,765 ft (S.R. McKinney \& Son, written commun., 1952).

WW-3 originally was drilled as a test well to help find locations for other water-supply wells (U.S. Department of Energy, 1996b, p. 1-1). Upon completion in March 1952, well WW-3 (1800 ft) was used for water supply (Moore, 1961, p. 8; U.S. Department of Energy, 1996b, p. 1-1). From 1952 to 1970, about $203 \mathrm{Mgal}$ of water were withdrawn from the well (fig. 53A; appendix A). Well WW-3 was taken out of service in 1970 because of high iron content, which was believed to be caused by corrosion of the well casing (U.S. Department of Energy, 1996b, p. 1-1).

Periodic water-level measurements made in well $W W-3$ (1800 ft) since 1952 are shown in figure 53B. The water levels range from about 1,528 to 1,595 ft below land surface. Water levels from 1952 to 1997 show the effects of pumping in the well. Maximum drawdown in the aquifer, as measured in the well, is about $50 \mathrm{ft}$.

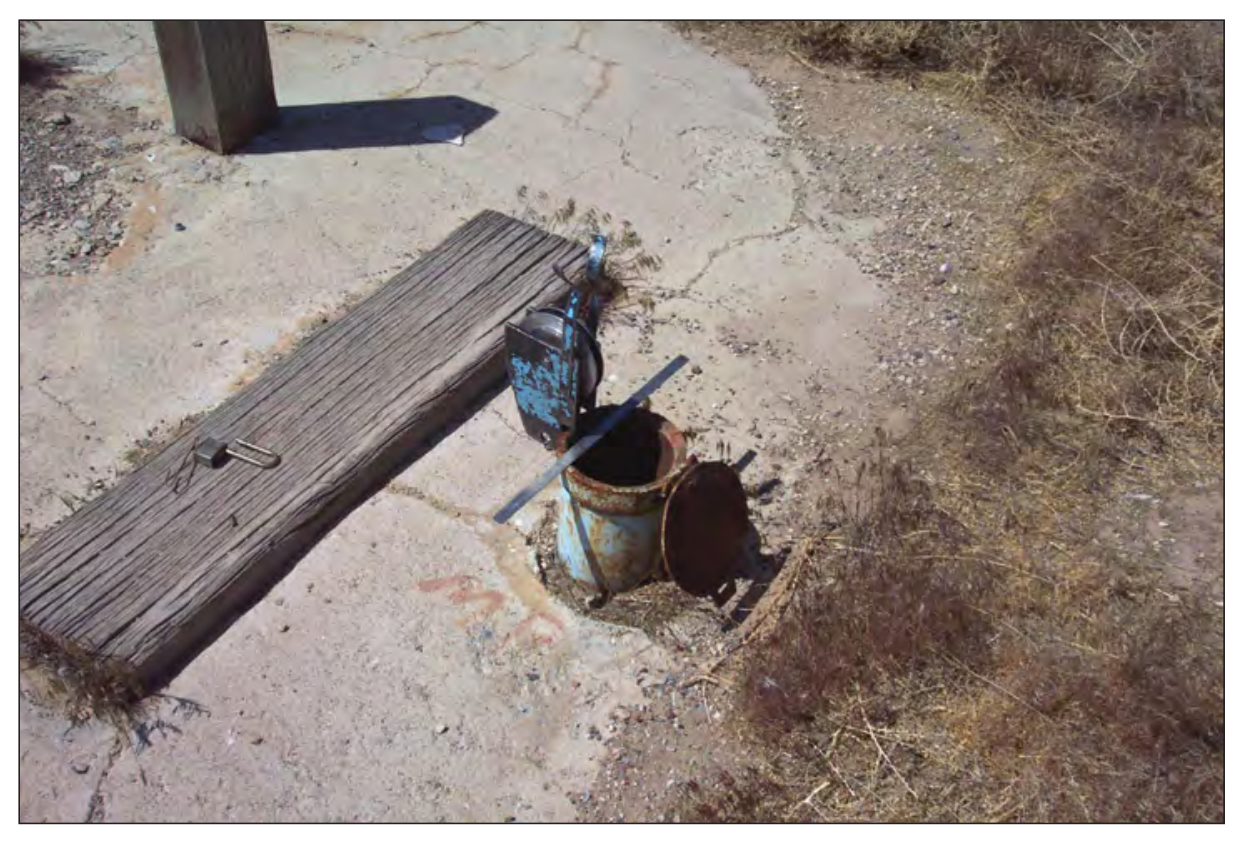

WW- 3, April 2009. Photograph by Terry L. Miller, U.S. Geological Survey. 
Well name: $W W-3$ (1800 ft)

USGS site identification No.: 365942116032901

Land-surface altitude: 3,969 feet above National Geodetic Vertical Datum of 1929 (NGVD29)

Latitude: -

Longitude: -

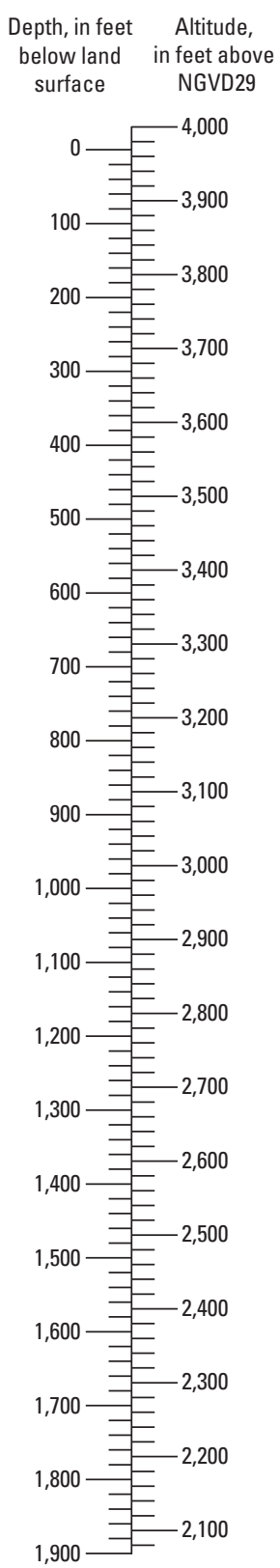

Lithology description

(from Wood, 2007)

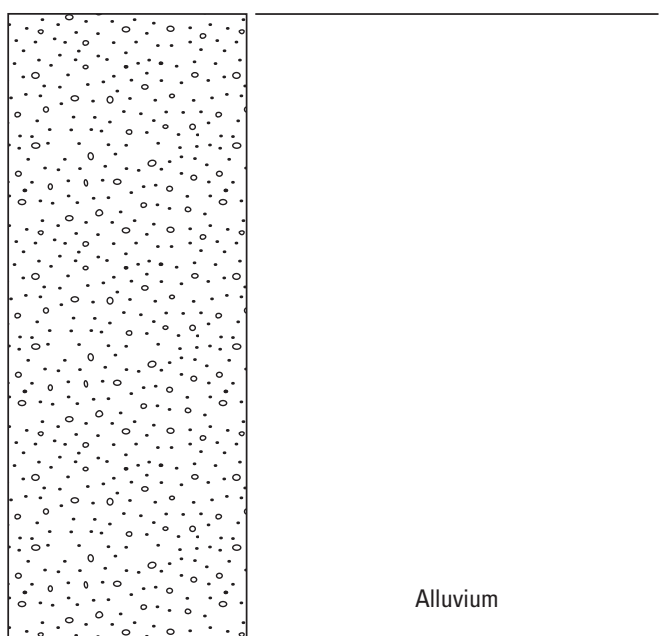

$\therefore \because$

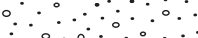

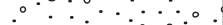

$\because \because \because \because \because \because$

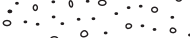

$\therefore \therefore \therefore \therefore \therefore$

$\because \because \because 0 \%$

$\therefore \therefore \therefore \therefore \therefore \circ$

$\therefore \therefore \circ 0$

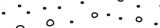

$\therefore \therefore \therefore \therefore$

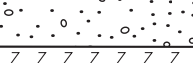

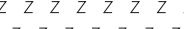

$\begin{array}{lllllllll}Z & Z & Z & Z & Z & Z & Z & Z\end{array}$

$\begin{array}{llllllll}Z & z & z & z & z & Z & z \\ z & z & z & z & z & z & z & z\end{array}$

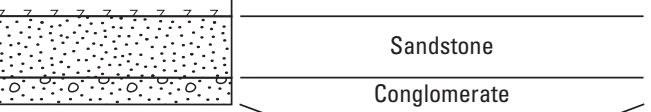

Nonwelded tuff

Conglomerate
Well-construction diagram (from Raytheon Services Nevada, written commun., no date; S.R. McKinney \& Son, written commun., 1951, 1952; Moore, 1961)
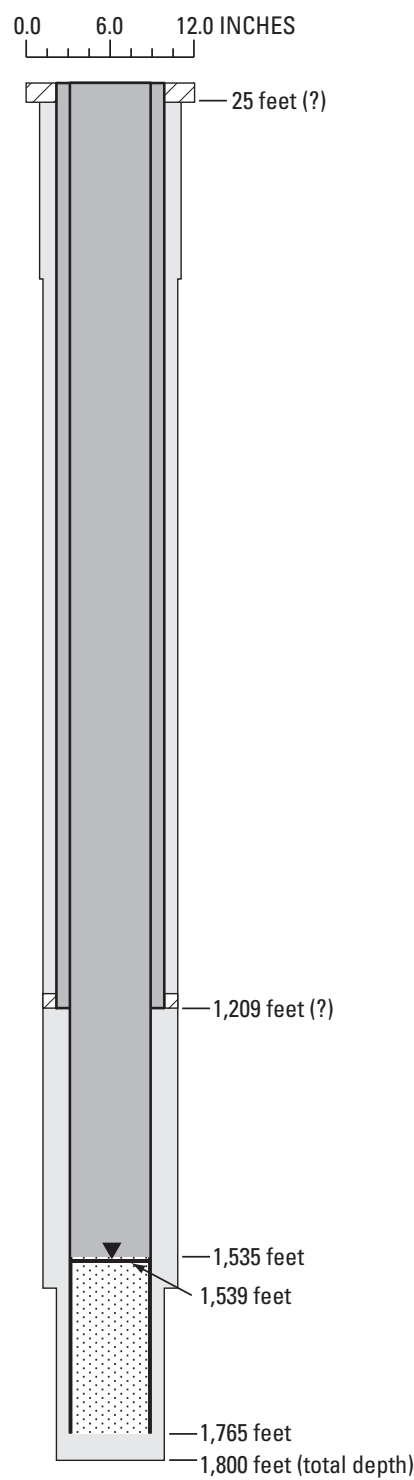

\section{EXPLANATION}

Open borehole or annulus

Casing

Figure 52. Borehole lithology and well construction for well WW-3 (1800 ft), Area 6, Nevada National Security Site, Nye County, Nevada. 

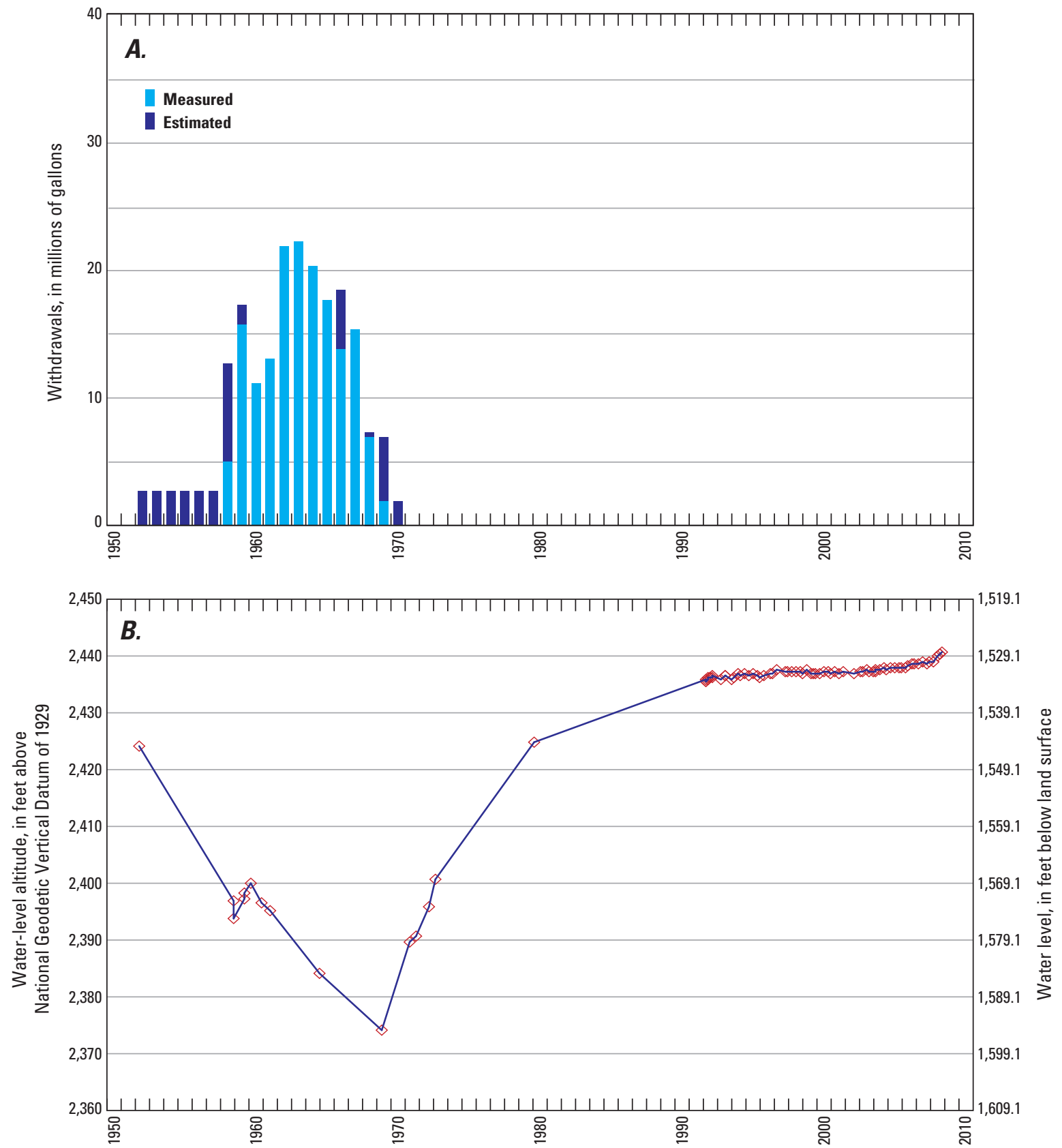

Figure 53. Annual groundwater withdrawals and water levels for well WW-3 (1800 ft), Area 6, Nevada National Security Site, Nye County, Nevada, 1952-2008. 
WW-4.-WW-4 is at the extreme northern end of Frenchman Flat in Area 6 of the NNSS (fig. 1; table 1; WW-4 photograph). Construction information for the borehole was compiled from Fenix \& Scisson, Inc., hole history data (written commun., 1982). The borehole was drilled to a depth of 1,479 ft below land surface and completed as a watersupply well in November 1981. The borehole was drilled using the conventional circulation method with air foam. Borehole diameter ranges from 36 in. at land surface to 20 in. at the bottom of the hole.

Borehole WW-4 has a single completion interval, well $W W-4$, which includes casing to a depth of 1,438 ft with a slotted interval from 942 to 1,436 ft (fig. 54). The annular space between the casing and borehole is open from 115 to $1,479 \mathrm{ft}$ and gravel packed from 898 to $1,438 \mathrm{ft}$; the casing is not cemented below a depth of $115 \mathrm{ft}$. The lithology at the saturated part of the open interval consists of alternating layers of welded and nonwelded tuffs (fig. 54; Wood, 2007). The principle water-bearing zone consists of the fractured, welded tuffs from 940 to 1,340 ft (Laczniak and others, 1996, p. 25; Wood, 2007).
WW-4 was drilled for water supply in Yucca Flat (Russell, 1989, p. 27), and has been part of DOE's hydrologic monitoring network since 1984 (Russell, 1989; Lyles, 1990; Bechtel Nevada, 2003; U.S. Department of Energy, 2008, p. 7-6). Well $W W-4$ was pumped briefly in 1981 for a production test, and then continuous pumping began in 1983. Pumping decreased in well $W W-4$ when continuous pumping in nearby well $W W-4 A$ began in July 1994. About 1,100 Mgal of water have been withdrawn from well $W W$-4 since 1981 (fig. 55A; appendix A).

Periodic water-level measurements made in well $W W-4$ since 1983 are shown in figure 55B. The water levels range from about 829 to $841 \mathrm{ft}$ below land surface. The initial water level in 1983 represents pre-pumping conditions in the aquifer. All other water levels show the effects of continuous pumping in the well. Water levels measured when the pump was on (not shown in fig. 55B) were drawn down as much as $20 \mathrm{ft}$ at a pumping rate of about $580 \mathrm{gal} / \mathrm{min}$.

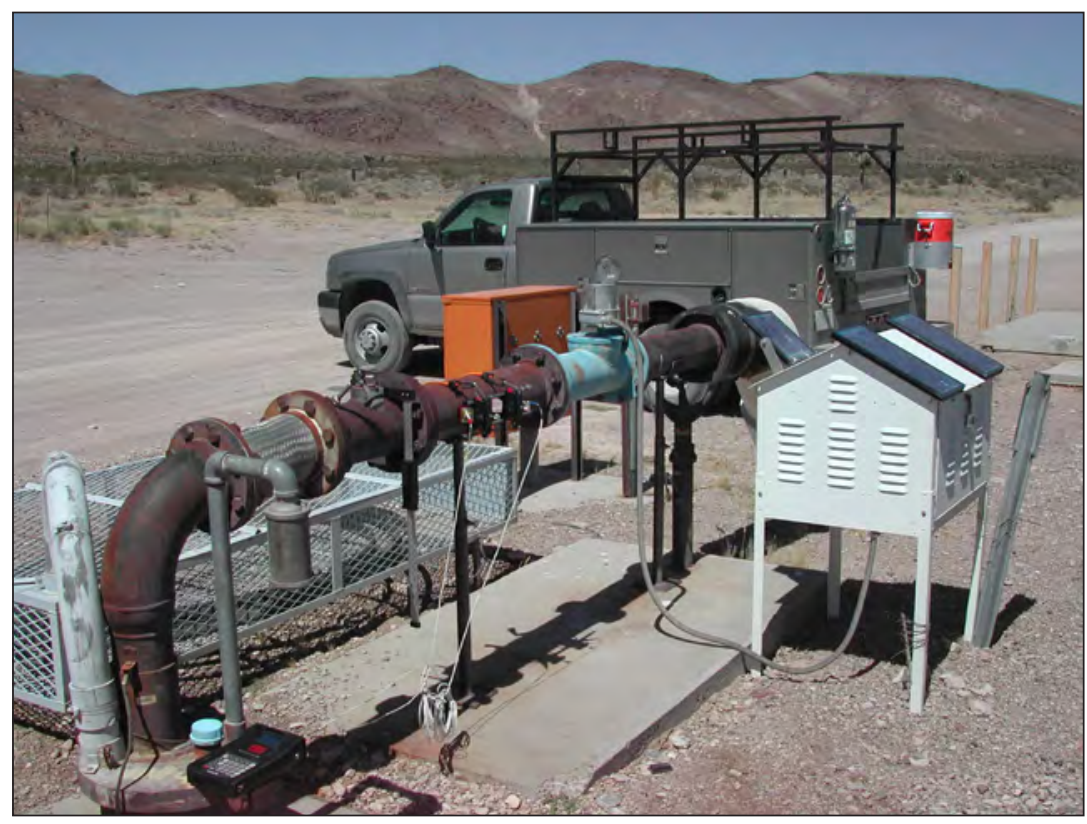

WW- 4, July 2005. Photograph by Richard J. La Camera, U.S. Geological Survey. 


\section{Well name: $W W-4$}

USGS site identification No.: 365418116012601

Land-surface altitude: 3,602 feet above National Geodetic Vertical Datum of 1929 (NGVD29) Latitude: -

Longitude:-
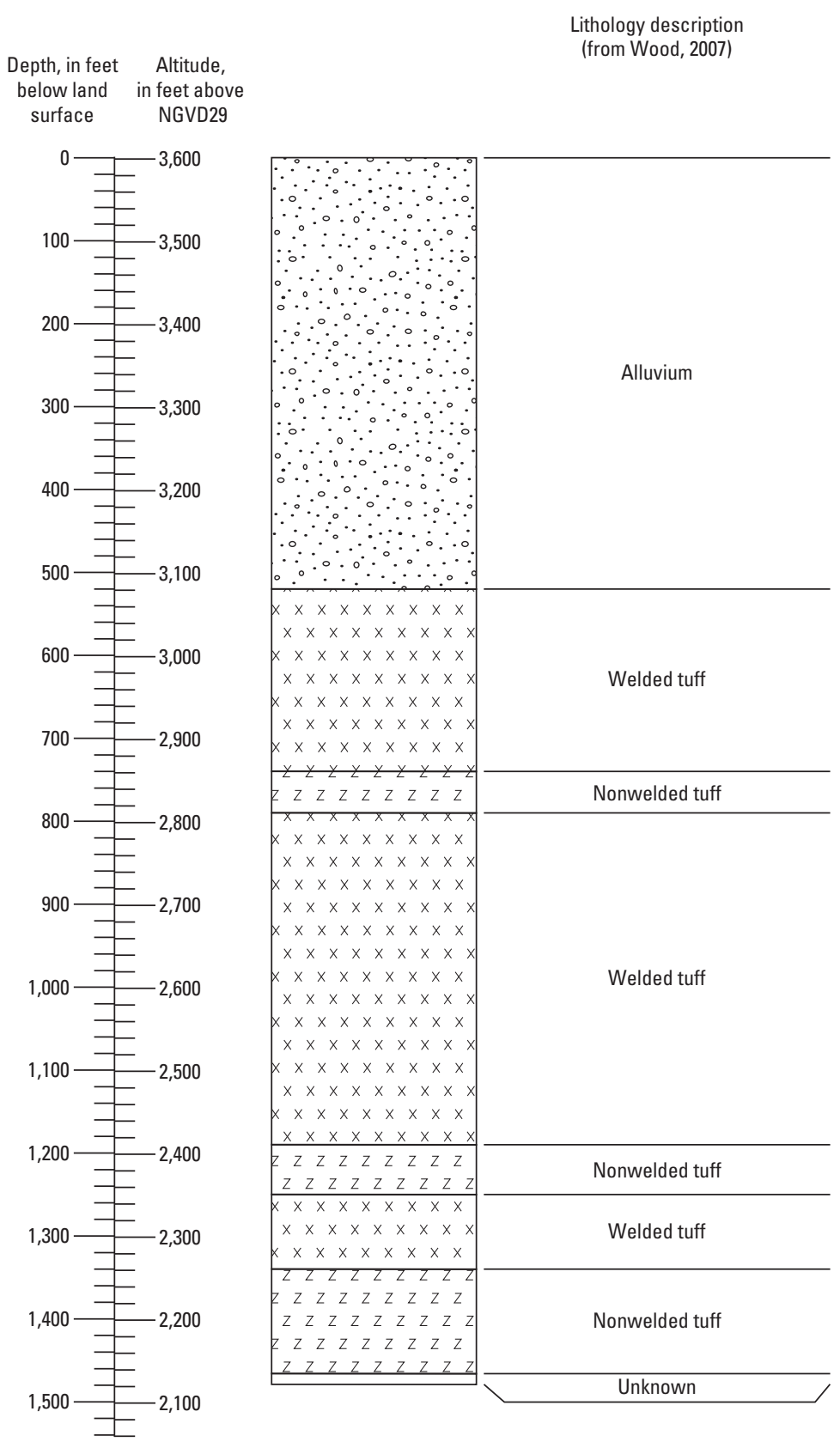

Well-construction diagram

(from Fenix \& Scisson, Inc. written commun., 1982)
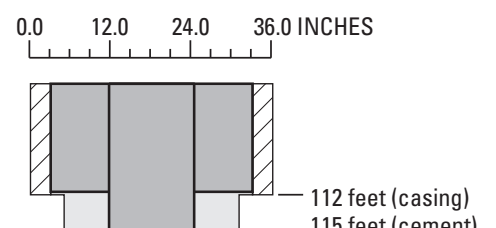

$\because \because \quad$ Alluvium

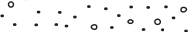

$\therefore \therefore \therefore$

$\because \because \cdots$

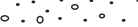

$x \times x \times x \times x \times$

$x \times \times \times \times \times \times \times \times x$

$x \times x \times x \times x \times x \times x$

Welded tuff

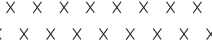

\begin{tabular}{|c|c|}
\hline 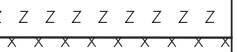 & Nonwelded tuff \\
\hline
\end{tabular}

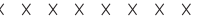

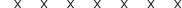

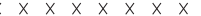

$x \times x \times x \times x \times$

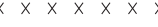

$z z z z z z z z$ $x x x x y x x x$

$x \times x \times x \times x \times x \times x$ $x \times x \times x \times x \times$

$z z z z z z z$
$z z z$

$z z z z z z z z$
$z z z z z z z z$

\section{EXPLANATION}

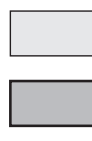

Open borehole or annulus

Casing
Slotted or perforated casing

Cement

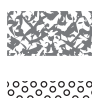

@o\%

Figure 54. Borehole lithology and well construction for well WW-4, Area 6, Nevada National Security Site, Nye County, Nevada. 

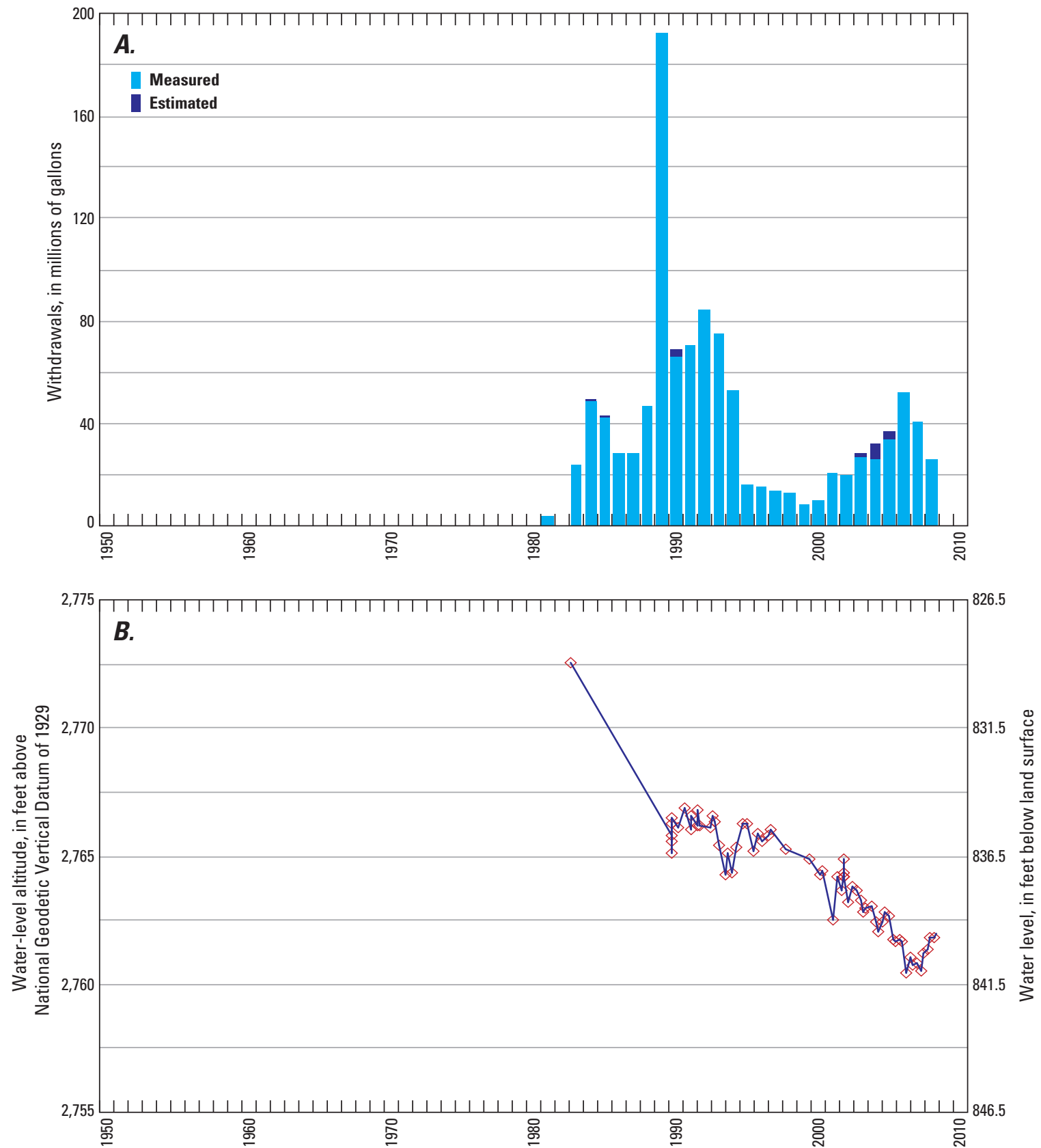

Figure 55. Annual groundwater withdrawals and water levels for well WW-4, Area 6, Nevada National Security Site, Nye County, Nevada, 1981-2008. 
WW-4A.-WW-4A is at the extreme northern end of Frenchman Flat in Area 6 of the NNSS (fig. 1; table 1; WW-4A photograph). Construction information for the borehole was compiled from Raytheon Services Nevada hole history data (written commun., no date). The borehole was drilled to a depth of $1,517 \mathrm{ft}$ below land surface and completed as a water-supply well in February 1990. The borehole was drilled using the conventional circulation method with mud and air foam. Borehole diameter ranges from 48 in. at land surface to $20.5 \mathrm{in}$. at the bottom of the hole.

Borehole WW-4A has a single completion interval, well $W W-4 A$, which includes casing to a depth of $1,501 \mathrm{ft}$ with two slotted intervals from 1,066 to $1,281 \mathrm{ft}$ and 1,365 to $1,457 \mathrm{ft}$ (fig. 56). The annular space between the casing and borehole is open from 536 to $1,517 \mathrm{ft}$ and gravel packed from 944 to $1,502 \mathrm{ft}$; the casing is not cemented below a depth of $536 \mathrm{ft}$. The lithology at the saturated part of the open interval consists of alternating layers of nonwelded and welded tuffs (fig. 56;
Wood, 2007). The primary water-bearing zone is the fractured, welded tuffs from 1,050 to 1,450 ft (Gillespie and others, 1996b, p. 40, 44; Wood, 2007).

WW-4A was drilled for water supply, and also has been part of DOE's hydrologic monitoring network since 1994 (Black and others, 1995; Bechtel Nevada, 2003; U.S. Department of Energy, 2008, p. 7-6). Well WW-4A was pumped sporadically from February 1990 to June 1994, and continuously since July 1994. Almost 790 Mgal of water have been withdrawn from the well since pumping began (fig. 57A; appendix A).

Periodic water-level measurements made in well $\mathrm{WW}$ $4 A$ since 1990 are shown in figure $57 \mathrm{~B}$. The water levels range from about 835 to $842 \mathrm{ft}$ below land surface. Water levels show the effects of continuous pumping in the well. Water levels measured when the pump was on (not shown in fig. 57B) were drawn down as much as $16 \mathrm{ft}$ at pumping rates of about $600-650 \mathrm{gal} / \mathrm{min}$.

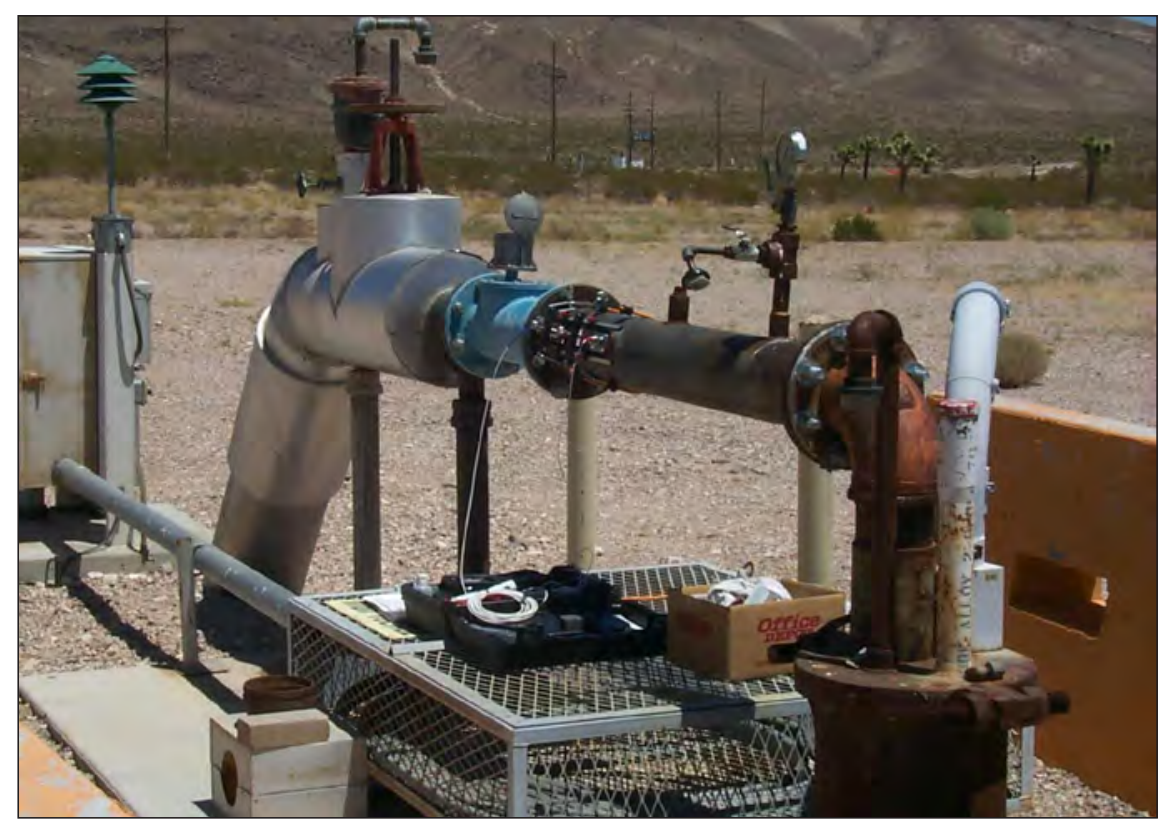

WW- 4A, July 2001. Photograph by Richard J. La Camera, U.S. Geological Survey. 
Well name: $W W-4 A$

USGS site identification No.: 365412116013901

Land-surface altitude: 3,606 feet above National Geodetic Vertical Datum of 1929 (NGVD29)

Latitude: -

Longitude:-
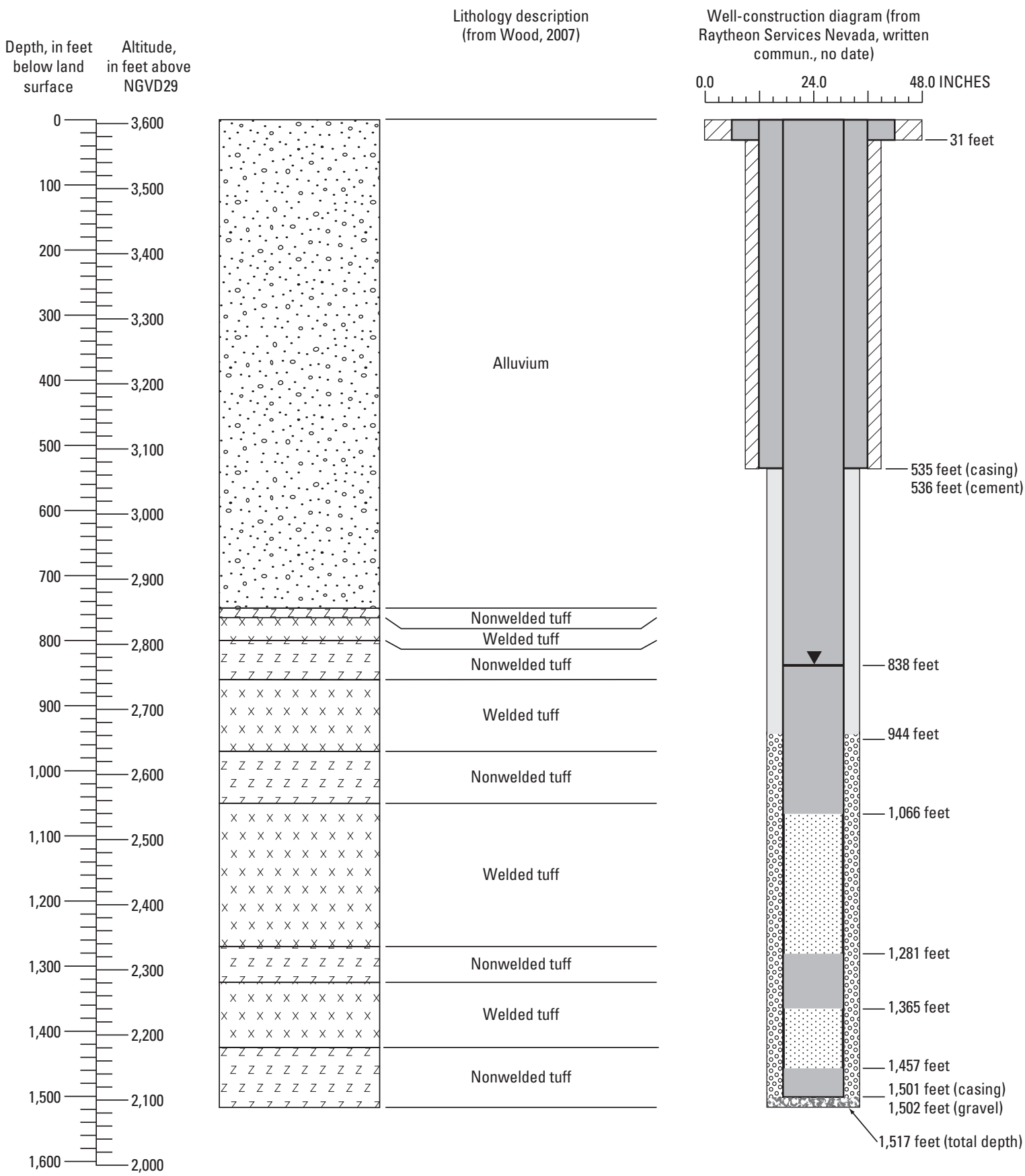

EXPLANATION

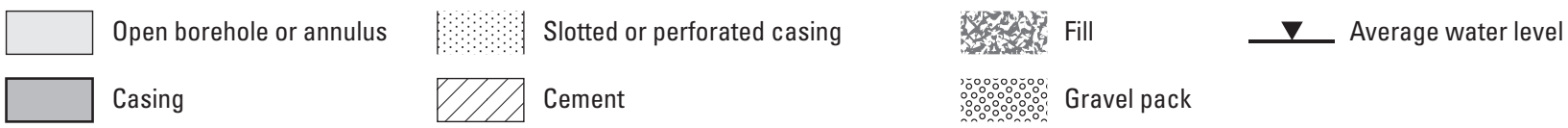

Figure 56. Borehole lithology and well construction for well $W W-4 A$, Area 6, Nevada National Security Site, Nye County, Nevada. 

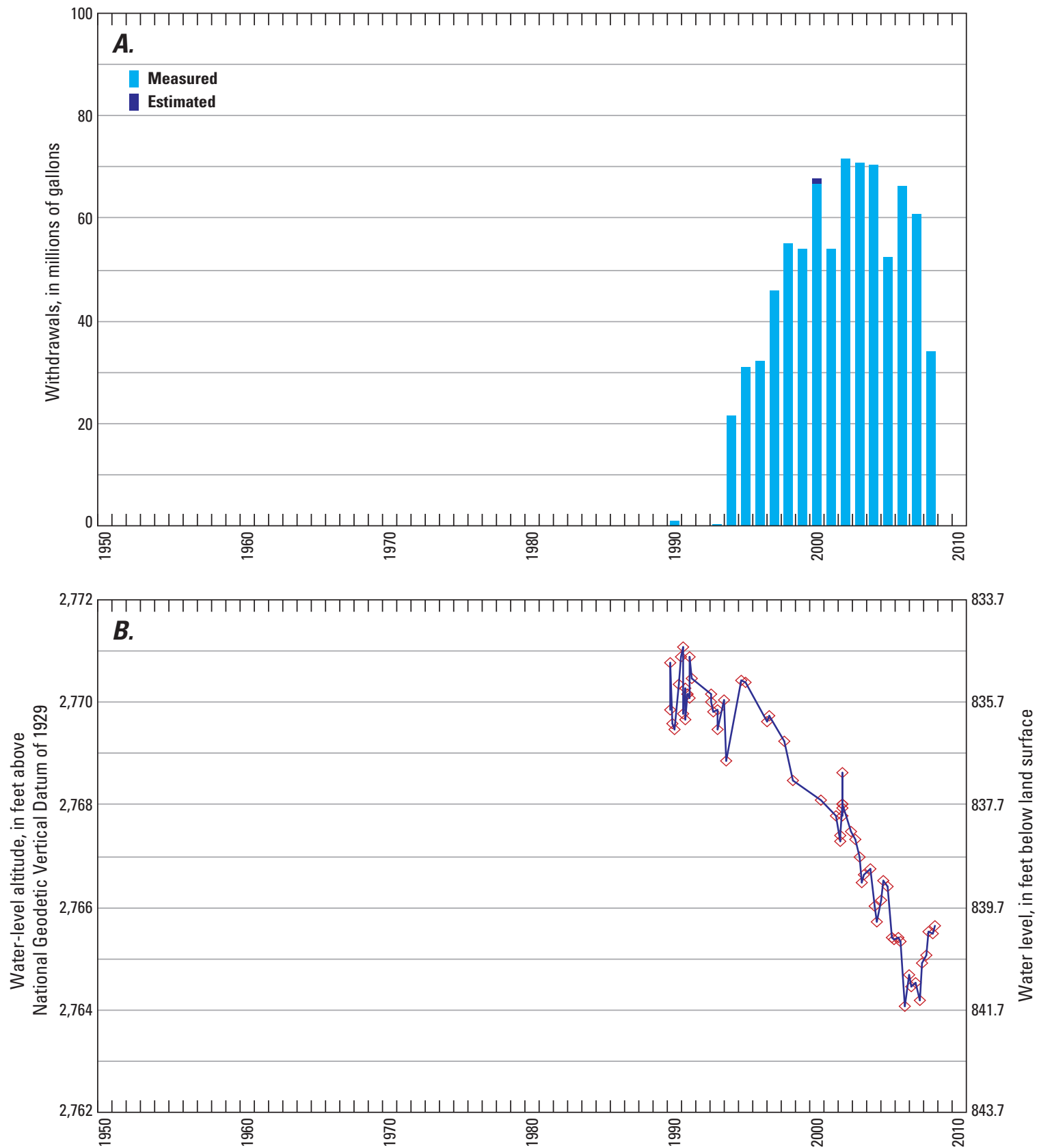

Figure 57. Annual groundwater withdrawals and water levels for well $W W-4 A$, Area 6, Nevada National Security Site, Nye County, Nevada, 1990-2008. 
WW-5A.-WW-5A is at the southern end of Frenchman Flat in Area 5 of the NNSS (fig. 1; table 1; WW-5A photograph). Construction information for the borehole was compiled from Fenix \& Scisson, Inc., hole history data (written commun., no date), S.R. McKinney \& Son (written commun., 1959), and U.S. Department of Energy (1996c). The borehole was drilled using the cable-tool method to a depth of $910 \mathrm{ft}$ below land surface and was completed as a watersupply well in March 1951. Borehole diameter ranges from 12 in. at land surface to $10 \mathrm{in}$. at the bottom of the hole.

Borehole WW-5A has a single completion interval, well $W W-5 A$, which includes casing to a depth of $877 \mathrm{ft}$ with a slotted interval from 642 to $877 \mathrm{ft}$, and an open borehole to $910 \mathrm{ft}$ (fig. 58). The casings were not cemented in the well annulus (U.S. Department of Energy, 1996c, p. 2-1); therefore, the annular space between the casing and borehole is open at least from $642 \mathrm{ft}$ to the bottom of the hole $(910 \mathrm{ft})$. The lithology at the saturated part of the open interval is tuffaceous conglomerate (fig. 58; Wood, 2007), which is the waterbearing unit in this well (Hood, 1961).

WW-5A was drilled for use as a water-supply well (U.S. Department of Energy, 1996c). Upon completion, well WW5A was pumped from 1951 to 1970 . More than $262 \mathrm{Mgal}$ of water were withdrawn from the well during this time (fig. 59A; appendix A).

Periodic water-level measurements made in well $W W-5 A$ since 1959 are shown in figure 59B. The water levels range from about 696 to $714 \mathrm{ft}$ below land surface. Water levels were measured after continuous pumping in the well and nearby wells $W W-5 B$ and $W W-5 C$ began. Although pumping ceased in well $W W-5 A$ in 1970 , pumping continued in nearby wells $W W$ $5 B$ and $W W-5 C$ through 2008.

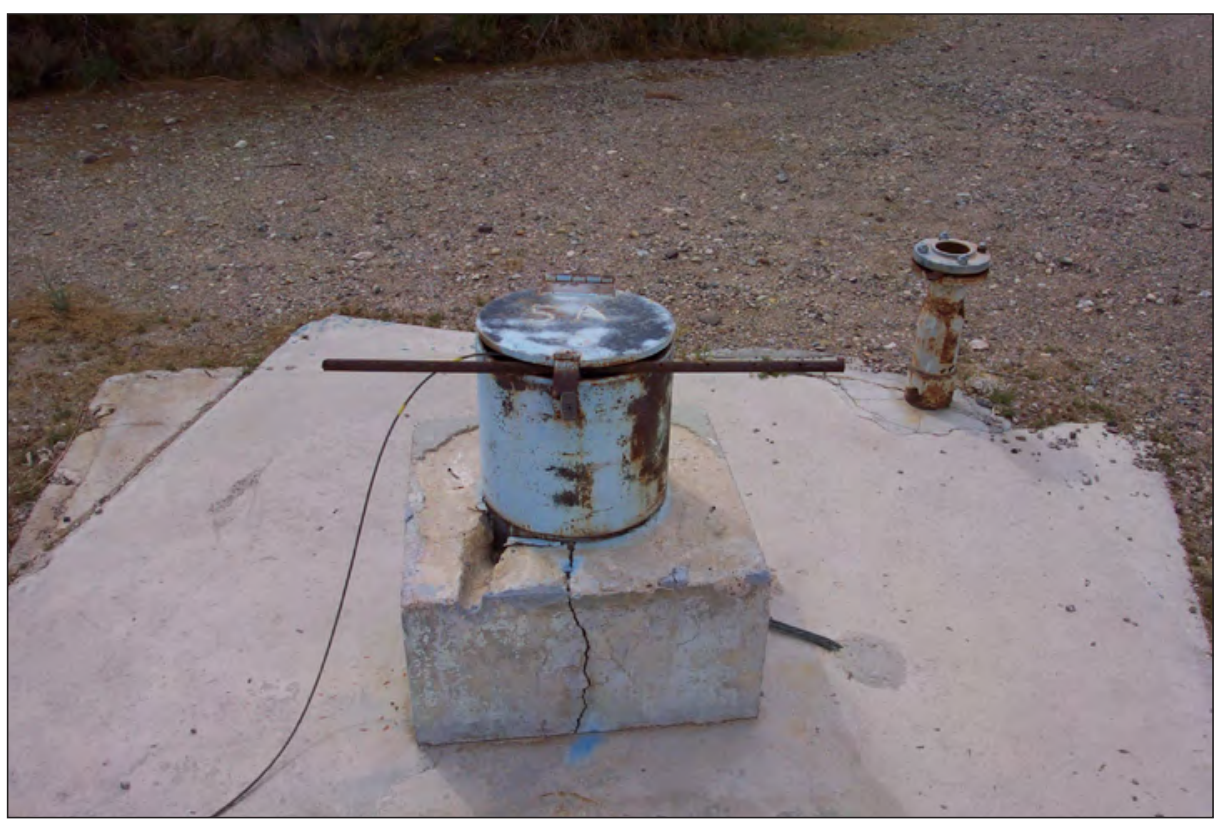

WW- 5A, April 2009. Photograph by Terry L. Miller, U.S. Geological Survey. 


\section{Well name: $W W-5 A$}

USGS site identification No.: 364635115572901

Land-surface altitude: 3,093 feet above National Geodetic Vertical Datum of 1929 (NGVD29)

Latitude:-

Longitude:-

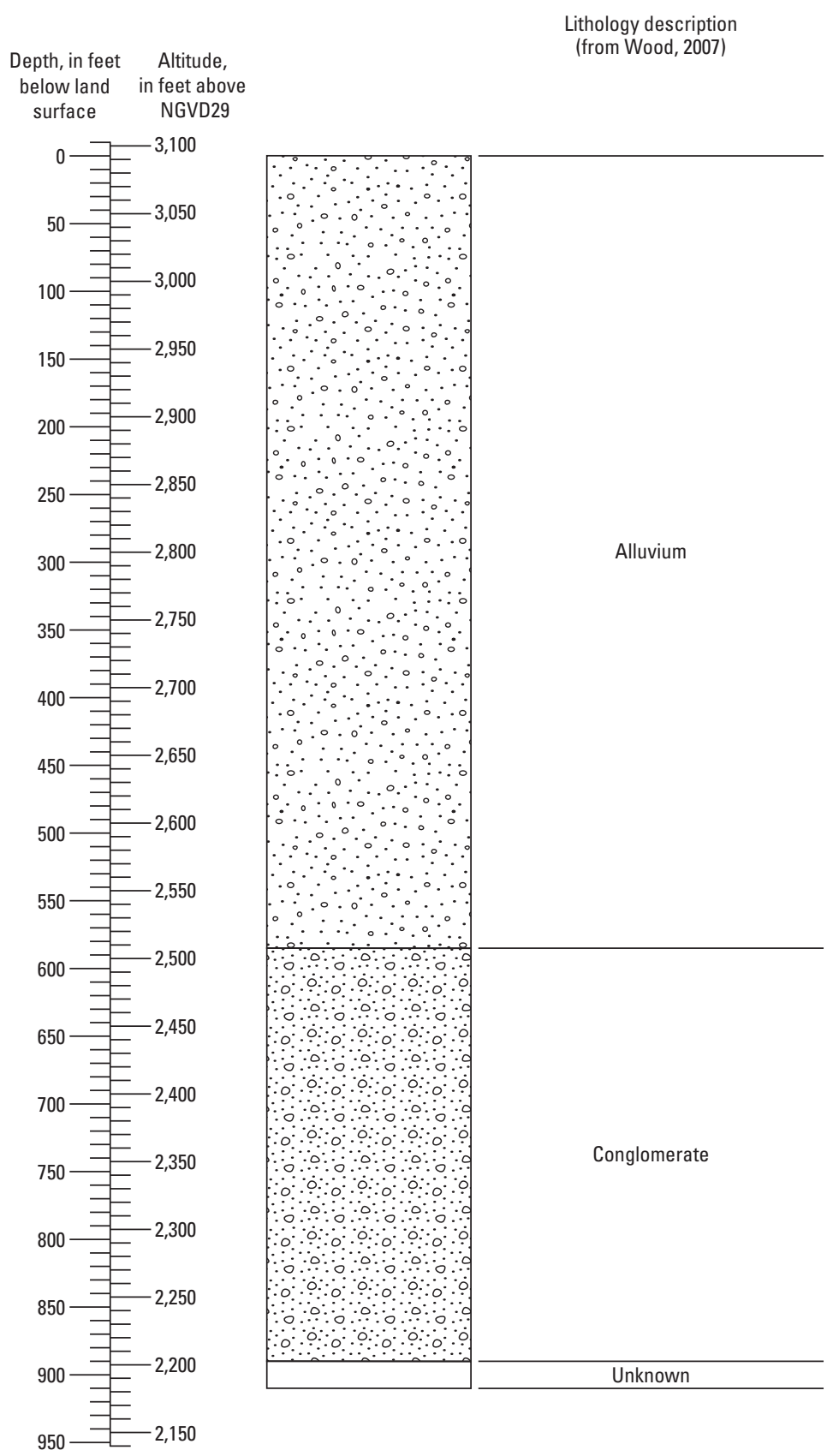

Well-construction diagram (from Fenix \&

Scisson, Inc., written commun., no date S.R. McKinney \& Son, written commun. 1959; U.S. Department of Energy, 1996c)

surface NGVD29
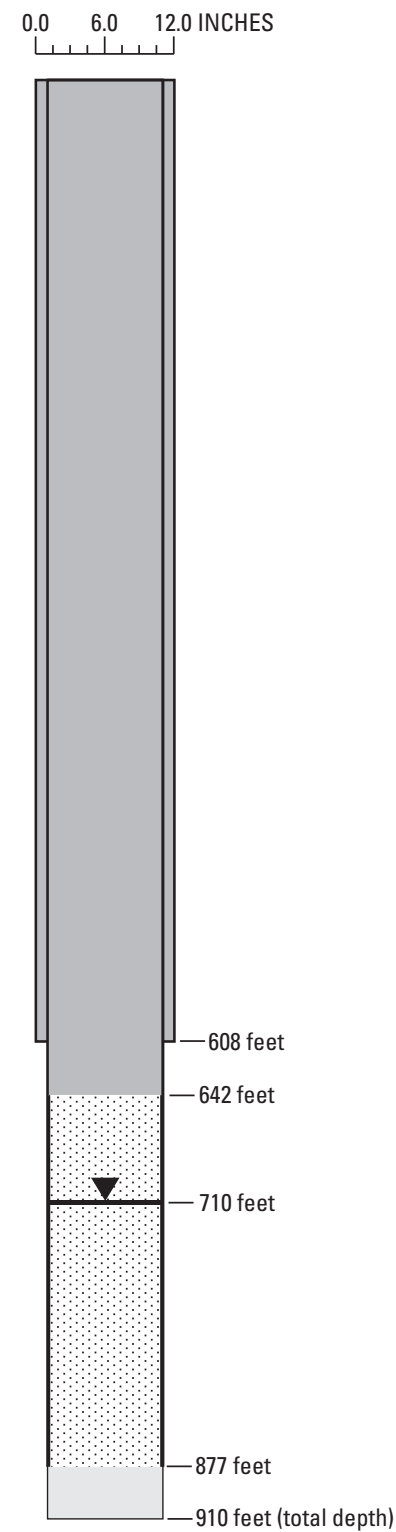

\section{EXPLANATION}

\begin{tabular}{|c|c|}
\hline Open borehole or annulus & Slotted or perforated casing \\
\hline Casing & Average water level \\
\hline
\end{tabular}

Figure 58. Borehole lithology and well construction for well WW-5A, Area 5, Nevada National Security Site, Nye County, Nevada. 

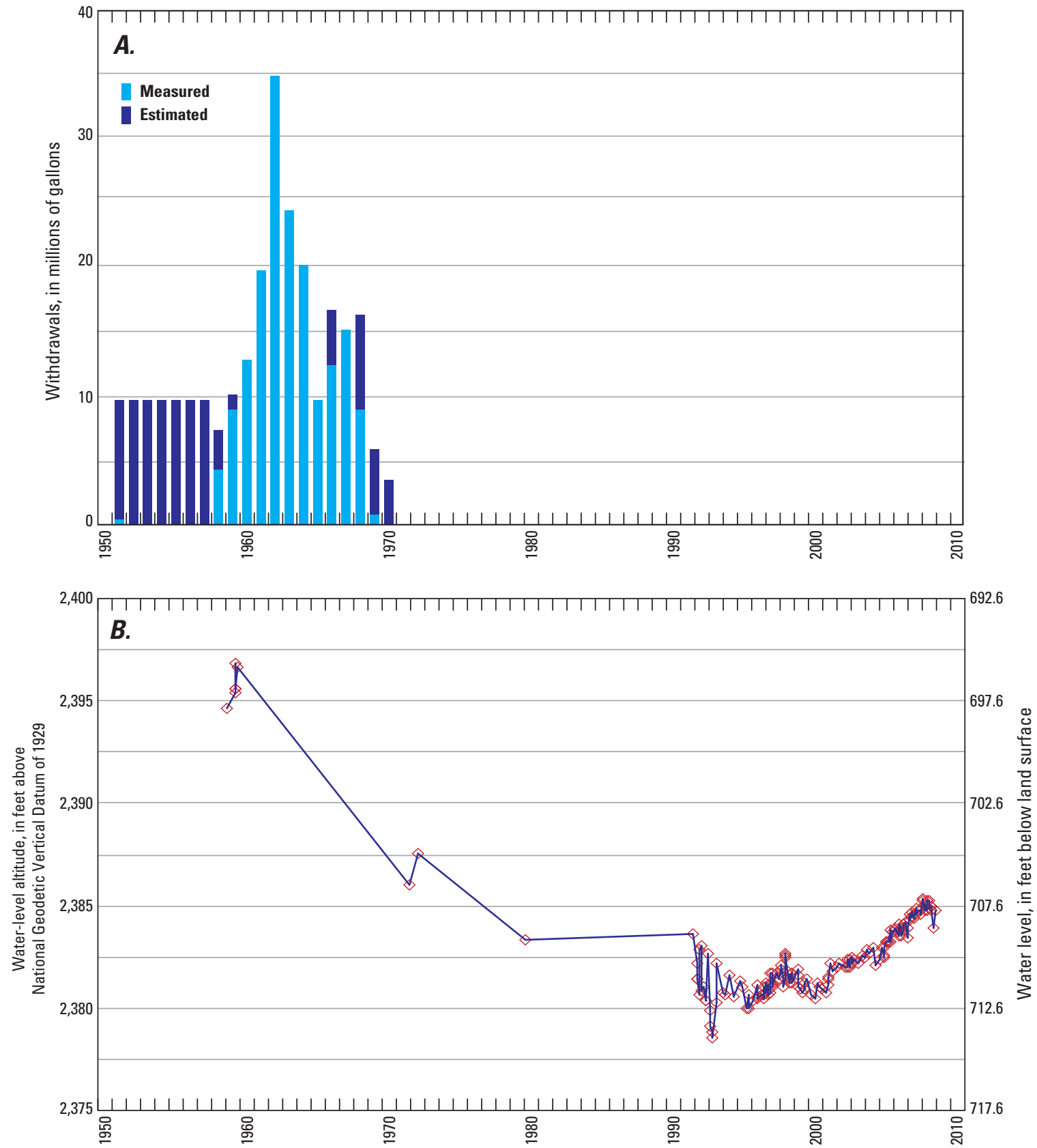

Figure 59. Annual groundwater withdrawals and water levels for well $W W-5 A$, Area 5, Nevada National Security Site, Nye County, Nevada, 1951-2008. 
WW-5B.-WW-5B is in Frenchman Flat in Area 5 of the NNSS (fig. 1; table 1; WW-5B photograph). Construction information for the borehole was compiled from S.R. McKinney \& Son (written commun., 1951) and Moore (1961). The borehole was drilled to a depth of $900 \mathrm{ft}$ below land surface using the cable-tool method and was completed in May 1951. Data on borehole diameter are not available; however, based on casing size, borehole diameter is at least $12 \mathrm{in}$. from land surface to the bottom of the hole (900 ft).

Borehole WW-5B has a single completion interval, well $W W-5 B$, which includes casing to a depth of $900 \mathrm{ft}$, with a slotted interval from 700 to $900 \mathrm{ft}$ (fig. 60). The annular space between the casing and borehole is open at least from $700 \mathrm{ft}$ to the bottom of the hole $(900 \mathrm{ft})$; data on cement in the well annulus or other types of seals in the well are not available. The lithology at the saturated part of the open interval consists of alluvium (fig. 60; Wood, 2007) and thus, the well produces water from the alluvial aquifer.

WW-5B was drilled as a water-supply well and provides water to Areas 5, 6, and 23 on the NNSS (Russell, 1989, p. 29; U.S. Department of Energy, 2008, p. 2-1). The well also has been part of DOE's hydrologic monitoring network since 1973 (Russell, 1989; Bechtel Nevada, 2003; U.S. Department of Energy, 2008, p. 7-6). About 1,720 Mgal of water have been withdrawn from the well since 1951 (fig. 61A; appendix A). The well was shut down from October 1988 (M.E. Ashbaugh, Reynolds Electrical \& Engineering Co., Inc., written commun., 1988) to May 1993, during which no pumping occurred; the well has been pumped continuously since May 1993.

Periodic water-level measurements made in well $W W$ $5 B$ since 1951 are shown in figure $61 B$. The water levels range from about 681 to $689 \mathrm{ft}$ below land surface. With the exception of the first measurement, which represents prepumping conditions in the aquifer, water levels in well $W W-5 B$ show the effects of continuous pumping in the well. Water levels measured in well $W W-5 B$ when the pump was on (not shown in figure $61 B$ ) were drawn down as much as $50 \mathrm{ft}$ at a pumping rate of about $610 \mathrm{gal} / \mathrm{min}$.

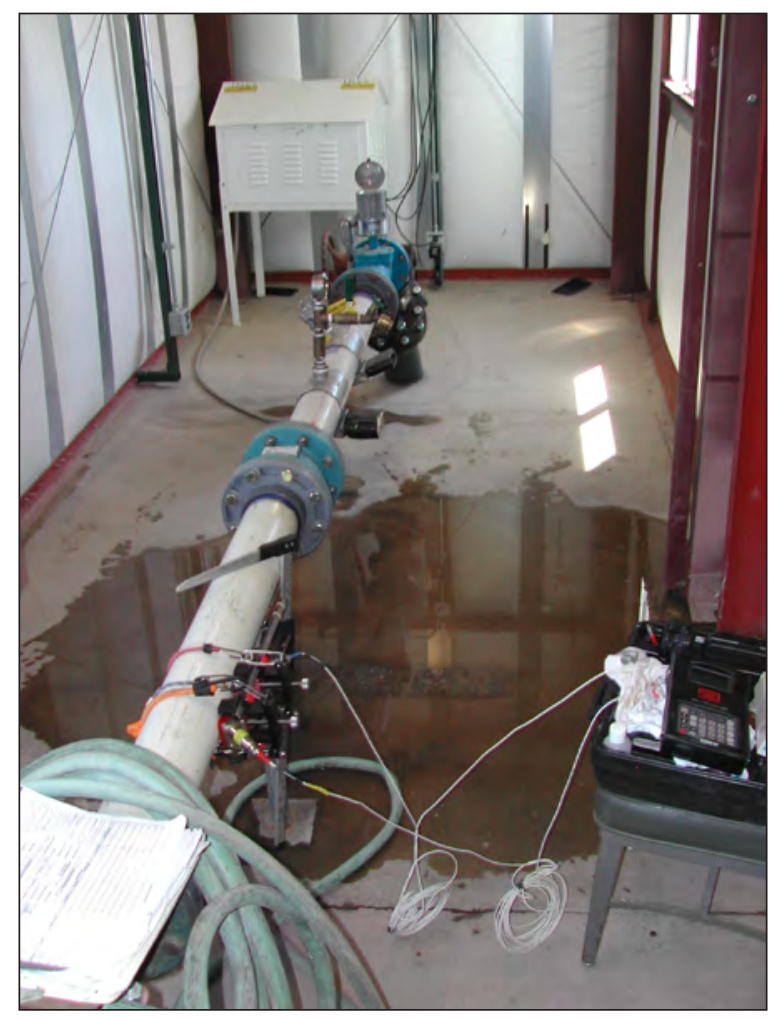

WW-5B, July 2005. Photograph by Richard J. La Camera, U.S. Geological Survey. 
Well name: $W W-5 B$

USGS site identification No.: 364805115580801

Land-surface altitude: 3,092 feet above National Geodetic Vertical Datum of 1929 (NGVD29)

Latitude: -

Longitude:-

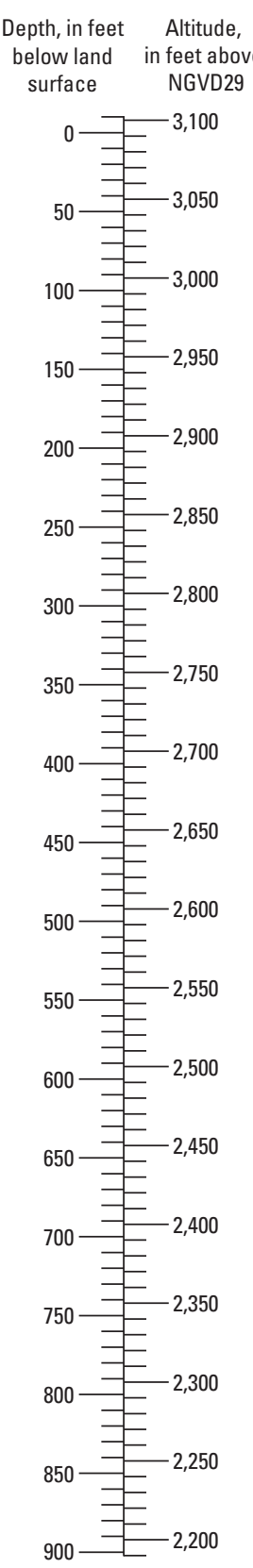

Lithology description

(from Wood, 2007)

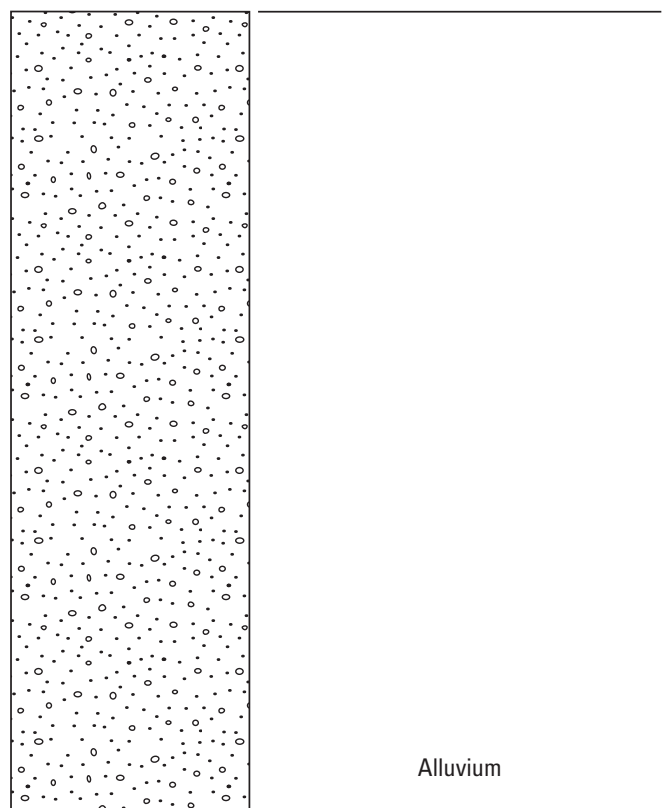

$\therefore$

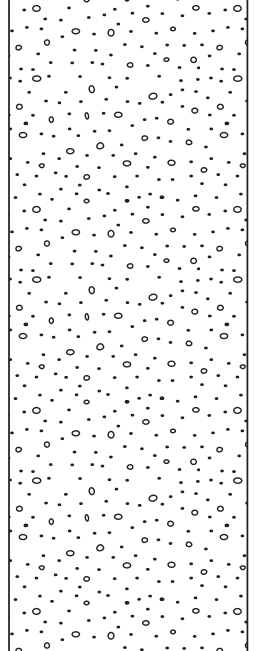

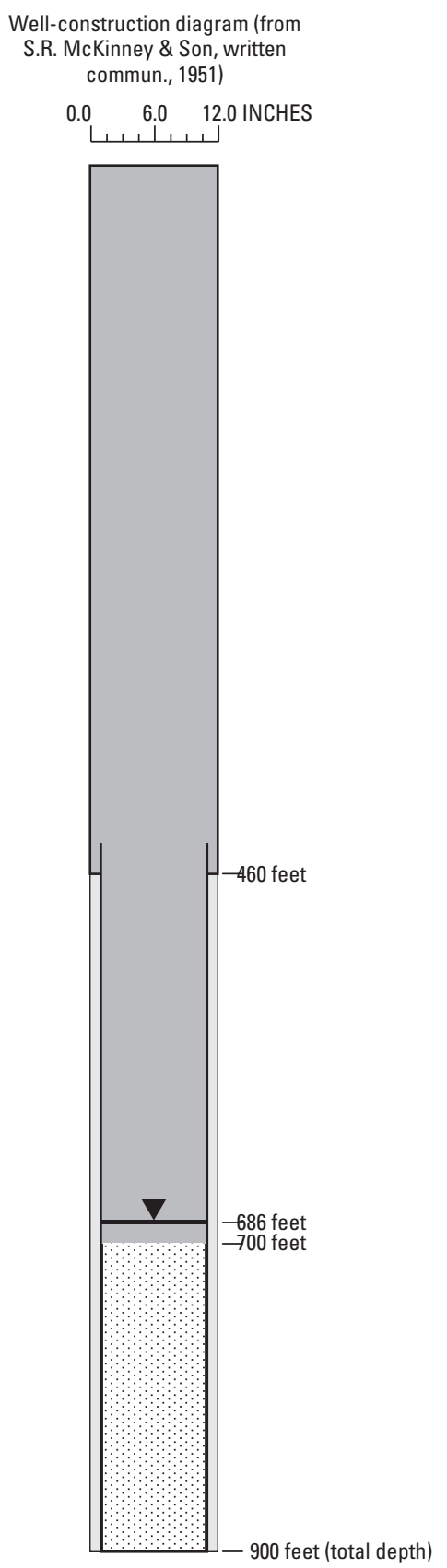

\section{EXPLANATION}

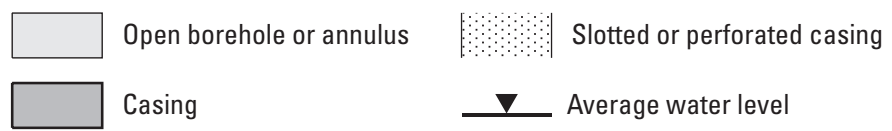

Figure 60. Borehole lithology and well construction for well WW-5B, Area 5, Nevada National Security Site, Nye County, Nevada. 

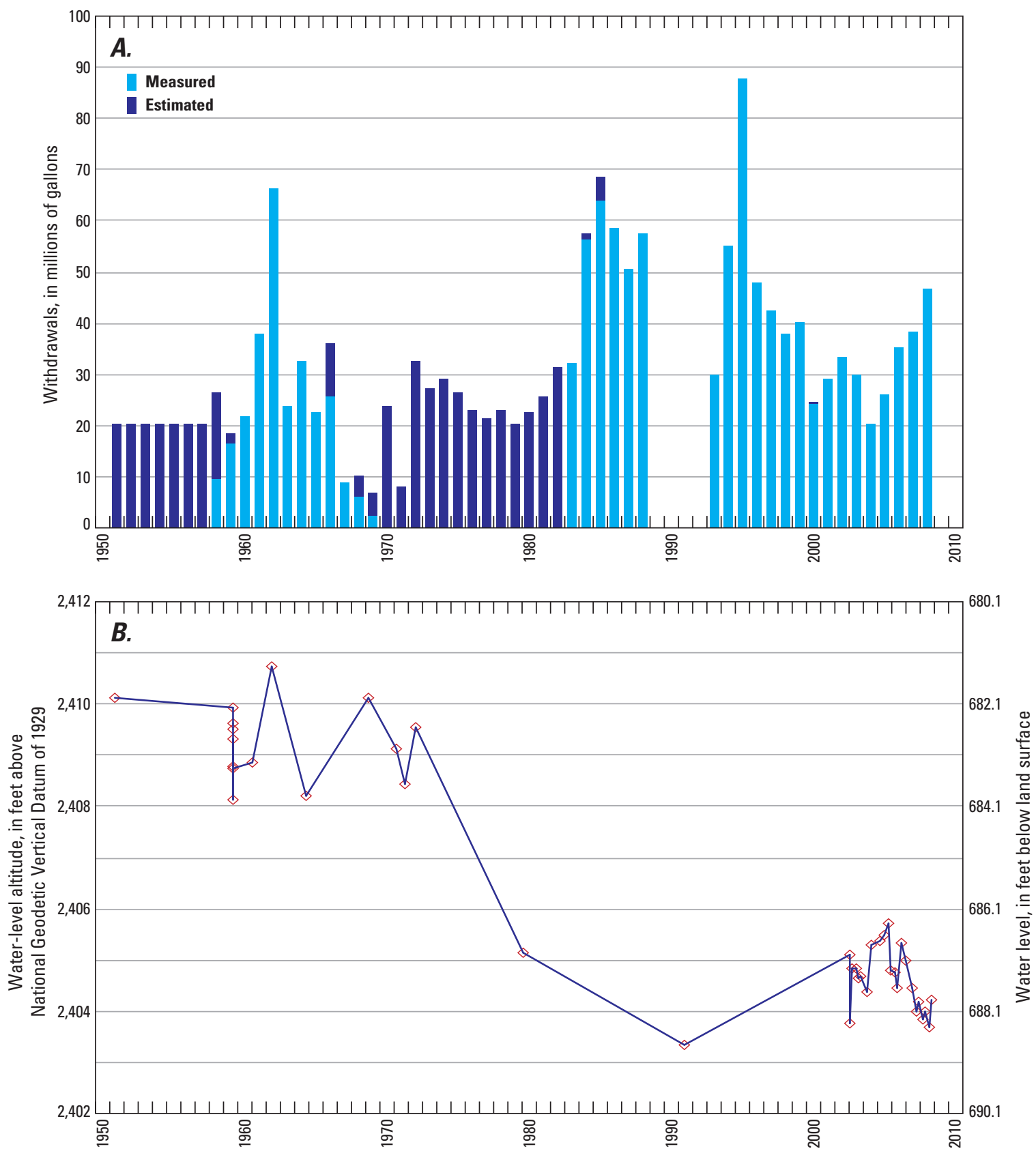

Figure 61. Graphs showing annual groundwater withdrawals and water levels for well $W W-5 B$, Area 5, Nevada National Security Site, Nye County, Nevada, 1951-2008. 
WW-5C.-WW-5C is in southern Frenchman Flat in Area 5 of the NNSS (fig. 1; table 1; WW-5C photograph). Construction information for the borehole was compiled from Moore (1961), Thordarson and others (1967), and Gillespie and others (1996b). The borehole was drilled to a depth of $1,200 \mathrm{ft}$ below land surface using the standard-rotary method and was completed in March 1954. Data on borehole diameter are not available; however, based on casing size, borehole diameter is at least $12 \mathrm{in}$. from land surface to a depth of $1,200 \mathrm{ft}$.

Borehole WW-5C has a single completion interval, well $W W-5 C$, which includes casing to a depth of $1,187 \mathrm{ft}$ with a slotted interval from 887 to $1,187 \mathrm{ft}$, and an open borehole to 1,200 ft (fig. 62). Gillespie and others (1996b, p. 11) reported that the 12-in. casing was cemented at the surface; therefore, the annular space between the casing and borehole likely is open below a depth of about $20 \mathrm{ft}$. Data on cement in the well annulus or other types of seals below $20 \mathrm{ft}$ are not available. The lithology at the saturated part of the open interval consists of alluvium (fig. 62; Wood, 2007) and thus, the well produces water from the alluvial aquifer.

WW-5C was drilled as a water-supply well (Russell, 1989, p. 29), and also has been part of DOE's hydrologic monitoring network since 1972 (Russell, 1989; Bechtel Nevada, 2003; U.S. Department of Energy, 2008, p. 7-6). Pumping in well $W W-5 C$ began in April 1954 and has been nearly continuous since then. More than 2,010 Mgal of water have been withdrawn from the well since 1954 (fig. 63A; appendix A).

Periodic water-level measurements made in well $W W-5 C$ from 1959 to 1993 are shown in figure 63B. The water levels range from about 689 to $730 \mathrm{ft}$ below land surface. Water levels show the effects of continuous pumping in the well.

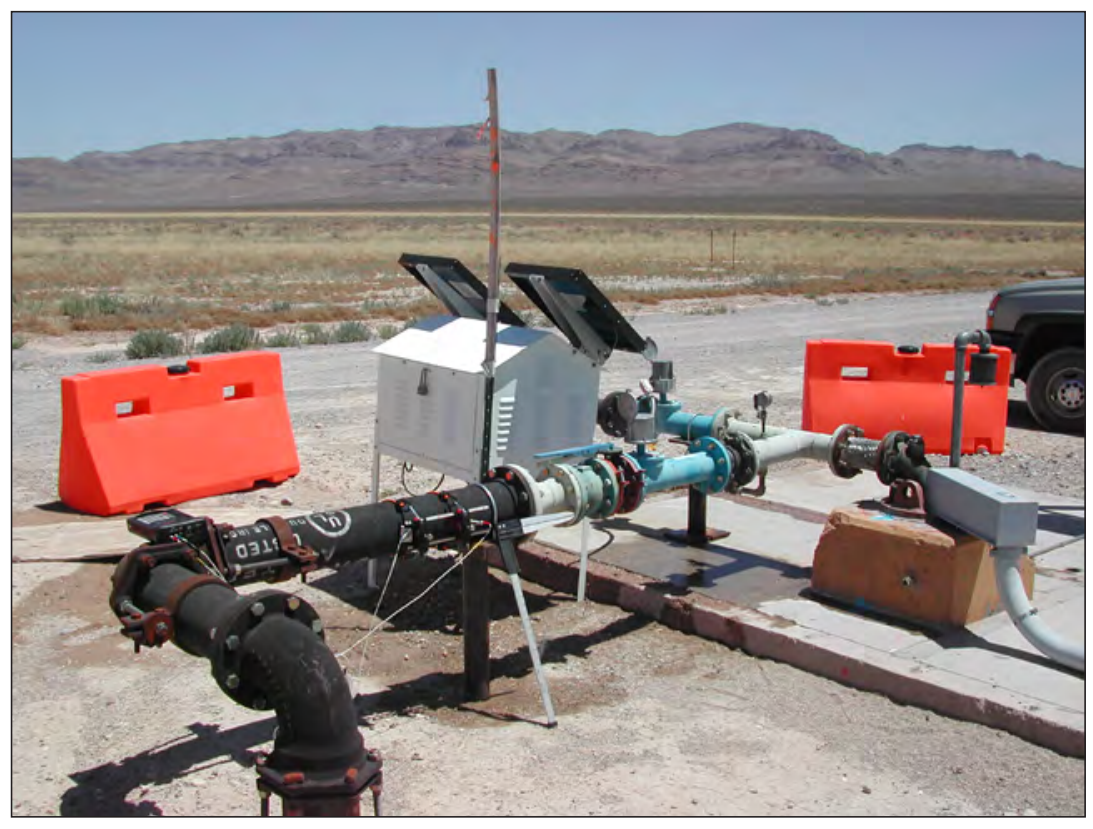

WW- 5C, July 2005. Photograph by Richard J. La Camera, U.S. Geological Survey. 
Well name: $W W-5 C$

USGS site identification No.: 364708115574401

Land-surface altitude: 3,082 feet above National Geodetic Vertical Datum of 1929 (NGVD29)

Latitude: -

Longitude:-
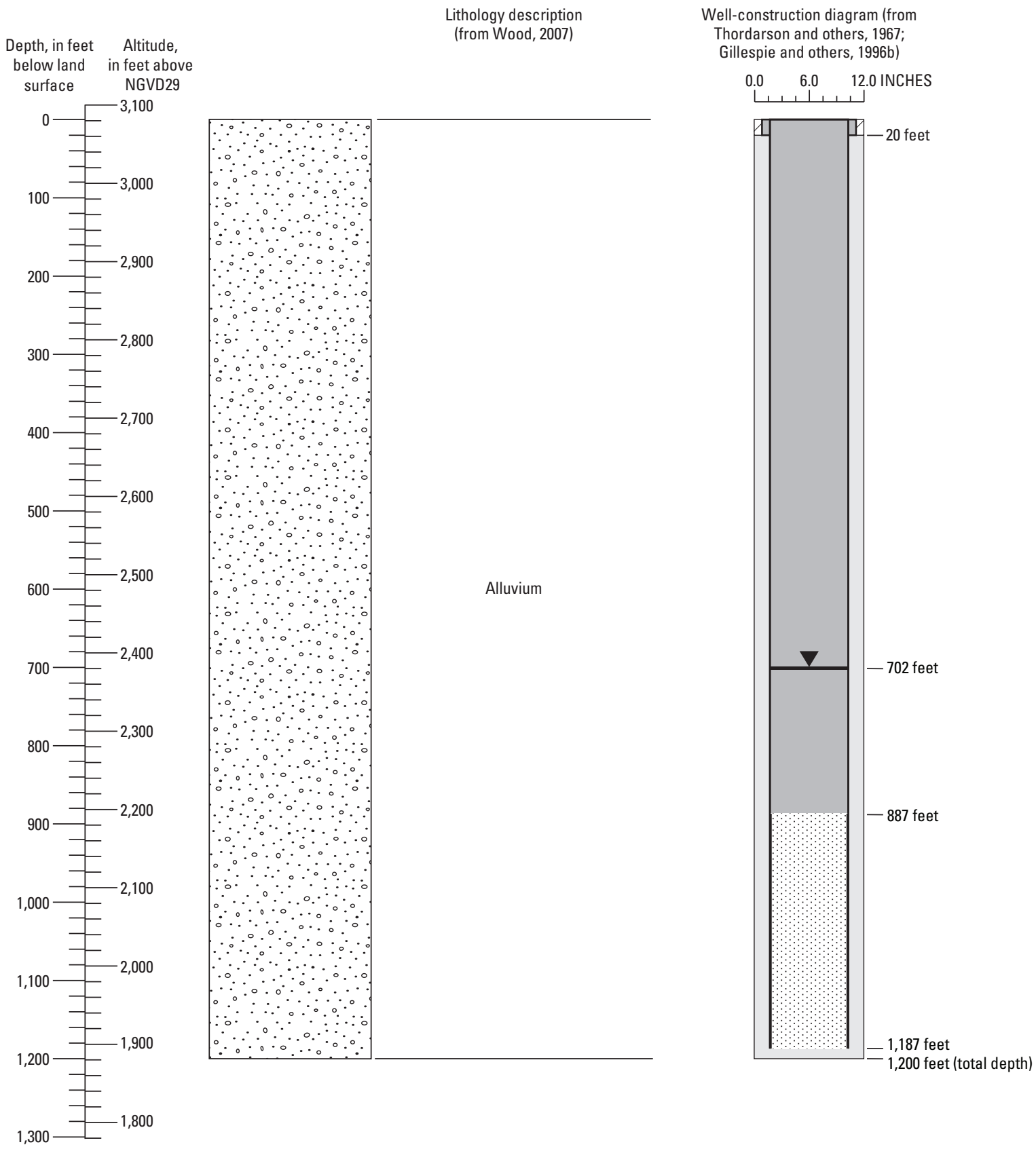

\section{EXPLANATION}

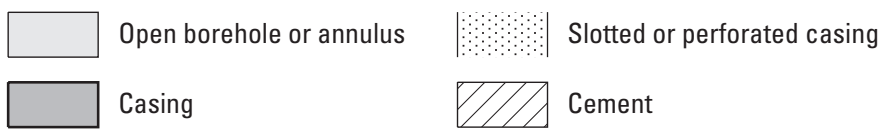

$\nabla$ Average water level

Figure 62. Borehole lithology and well construction for well WW-5C, Area 5, Nevada National Security Site, Nye County, Nevada. 

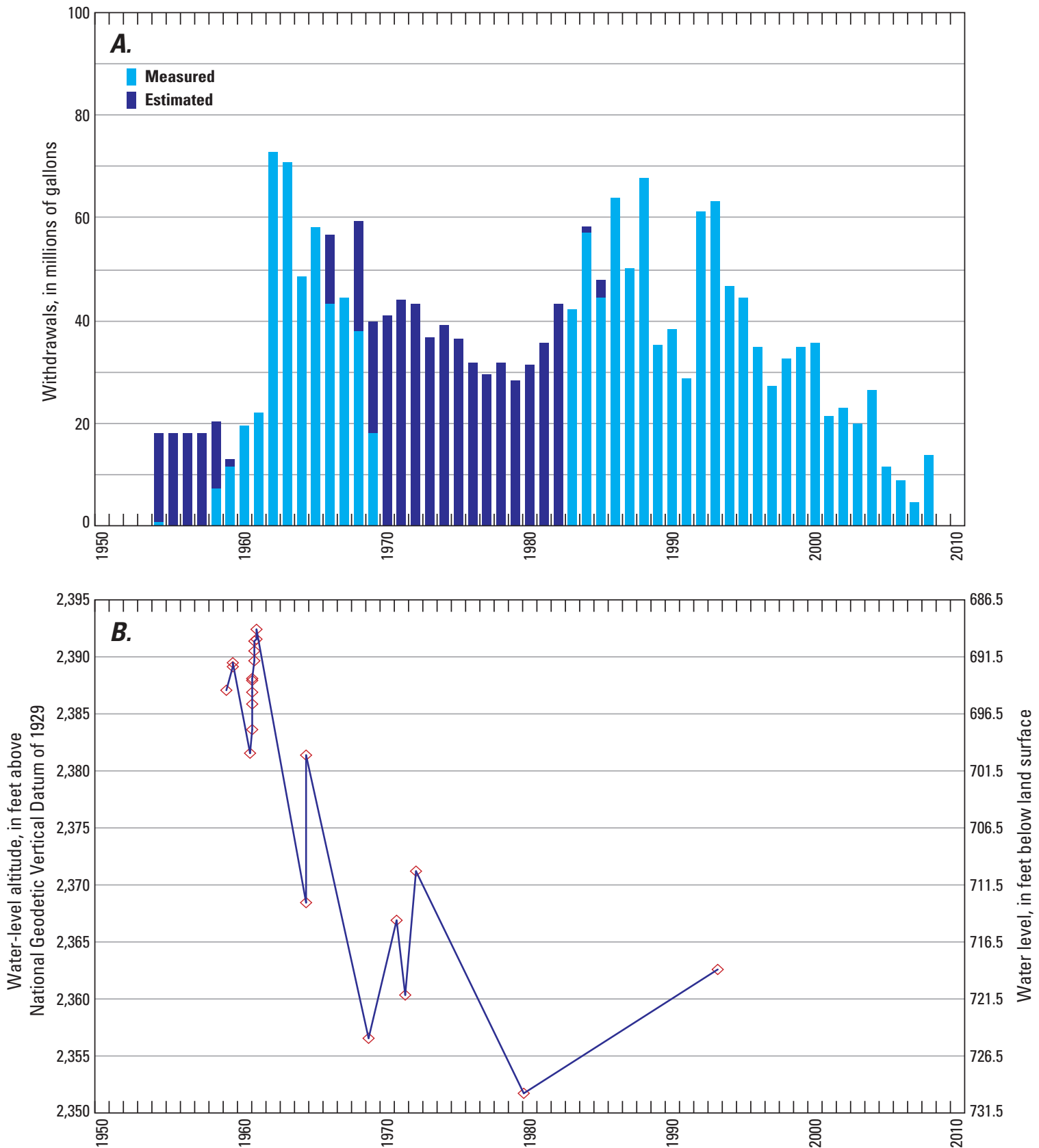

Figure 63. Annual groundwater withdrawals and water levels for well $W W-5 C$, Area 5, Nevada National Security Site, Nye County, Nevada, 1954-2008. 
WW-8.-WW-8 is southeast of Pahute Mesa in Area 18 of the NNSS (fig. 1; table 1; WW-8 photograph). Construction information for the borehole was compiled from L.R. West and William Thordarson, U.S. Geological Survey (written commun., 1963), and Fenix \& Scisson, Inc., hole history data (written commun., 1989). The borehole was drilled using the hydraulic-rotary method with air and mud to a total depth of 5,490 ft below land surface in December 1962. Borehole diameter ranges from $20 \mathrm{in}$. at land surface to $6.12 \mathrm{in}$. at the bottom of the hole $(5,490 \mathrm{ft})$.

Borehole WW-8 has two completion intervals, well $W W-8(2031-5490 \mathrm{ft})$ and well $W W-8(30-2031 \mathrm{ft})$. Well $W W-8$ (2031-5490 ft) represents the hole as it was completed in December 1962. This completion includes casing to a depth of 2,936 ft and an open borehole to 5,490 ft (fig. 64A). The casing is slotted from 2,038 to 2,070 ft and 2,137 to 2,170 ft, and the annular space between the casing and borehole is open below 2,031 ft. The lithology at the saturated part of the open interval consists of alternating layers of welded and nonwelded tuffs (fig. 64; Warren and others, 2003; Wood, 2007). Based on pumping tests done in the well, these volcanic tuffs have a relatively low specific capacity (L.R. West and William Thordarson, U.S. Geological Survey, written commun., 1963, p. 15).

Borehole WW-8 was recompleted on January 7, 1963, after a cement bridge plug was installed at a depth of $1,862 \mathrm{ft}$ sealing off the lower part of the borehole. Well WW-8 (30$2031 \mathrm{ft}$ ) represents the hole after this recompletion. This second completion includes casing to a depth of 2,936 ft, but above the bridge plug the casing is perforated from 1,250 to $1,300 \mathrm{ft}$; 1,450 to $1,500 \mathrm{ft}$; and 1,630 to $1,780 \mathrm{ft}$; and the annular space between the casing and borehole is open from
30 to about 2,031 ft (fig. 64B). The lithology at the saturated part of the open interval consists of alternating layers of welded and nonwelded tuffs interbedded with lava (fig. 64; Warren and others, 2003; Wood, 2007). Most of the water in the well originates from the interval 1,068 to 2,031 ft, specifically from the rhyolitic lava flows and interbedded tuffs between 1,290 and 2,010 ft (L.R. West and William Thordarson, U.S. Geological Survey, written commun., 1963, pp. 3-4; Gillespie and others, 1996b, p. 37).

WW-8 originally was drilled as an exploratory hole and later was used for water supply in Area 12 (Thordarson and others, 1967, p. 18; Russell, 1989, p. 31). WW-8 also has been part of DOE's hydrologic monitoring network since 1973 (Russell, 1989; Bechtel Nevada, 2003; U.S. Department of Energy, 2008, p. 7-6). About 1,800 Mgal of water have been withdrawn from the borehole since 1963 (fig. 65A; appendix A). Well WW-8 (2031-5490 ft) was used only for hydraulic testing, in which about $0.15 \mathrm{Mgal}$ of water were withdrawn during a production test from January 3 to 6, 1963 (L.R. West and William Thordarson, U.S. Geological Survey, written commun., 1963, p. 15). Most of the water from WW-8 was supplied by well $W W-8(30-2031 \mathrm{ft})$; pumping in this well began a few days after the production test.

Periodic water-level measurements made in WW-8 from 1963 to 2000 are shown in figure $65 \mathrm{~B}$. Two water levels were measured in well $W W-8(2031-5490 \mathrm{ft})$ at about 1,070 and $1,071 \mathrm{ft}$ below land surface. Water levels in well $W W-8$ (30$2031 \mathrm{ft}$ ) range from about 1,068 to $1,083 \mathrm{ft}$ below land surface. The highest water level measured in both well completions in 1963 represents pre-pumping conditions. Water levels measured from 1971 to 2000 show the effects of pumping in the well.

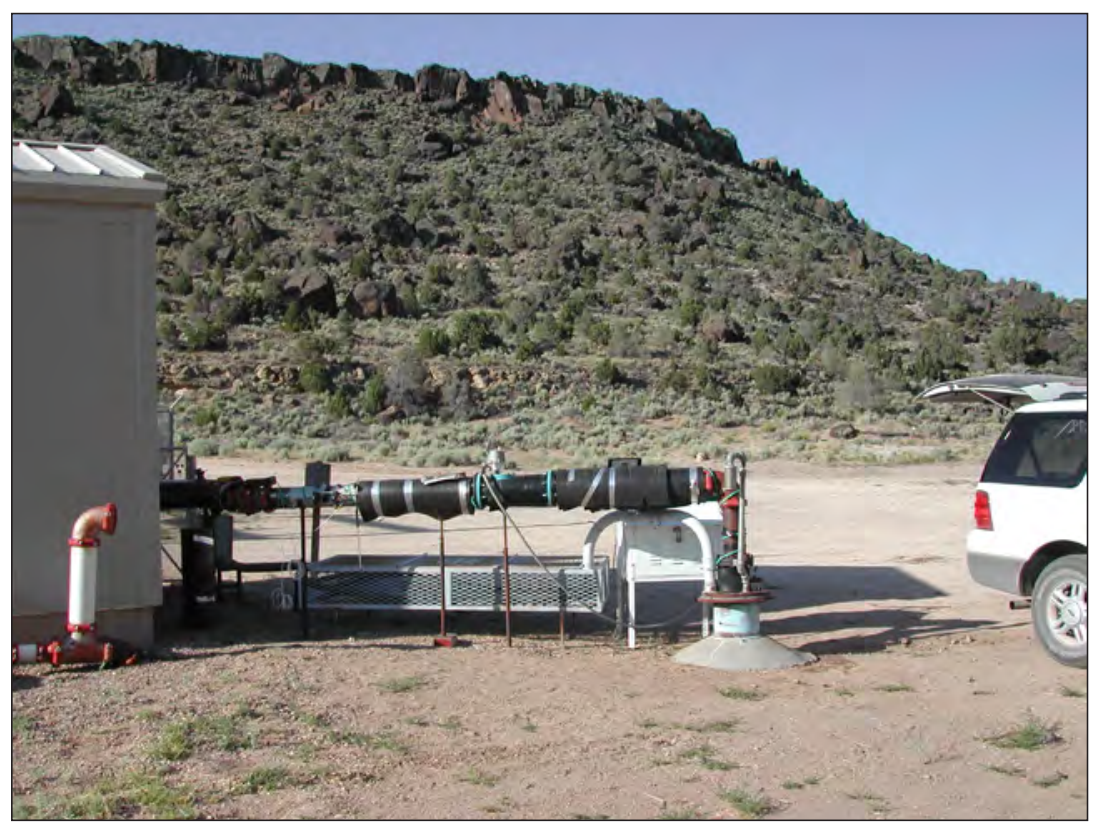

WW- 8, July 2005. Photograph by Richard J. La Camera, U.S. Geological Survey. 
Well name: WW-8 (2031-5490 ft)

USGS site identification No.: 370956116172133

Land-surface altitude: 5,695 feet above National Geodetic Vertical Datum of 1929 (NGVD29) Latitude: -

Longitude: -

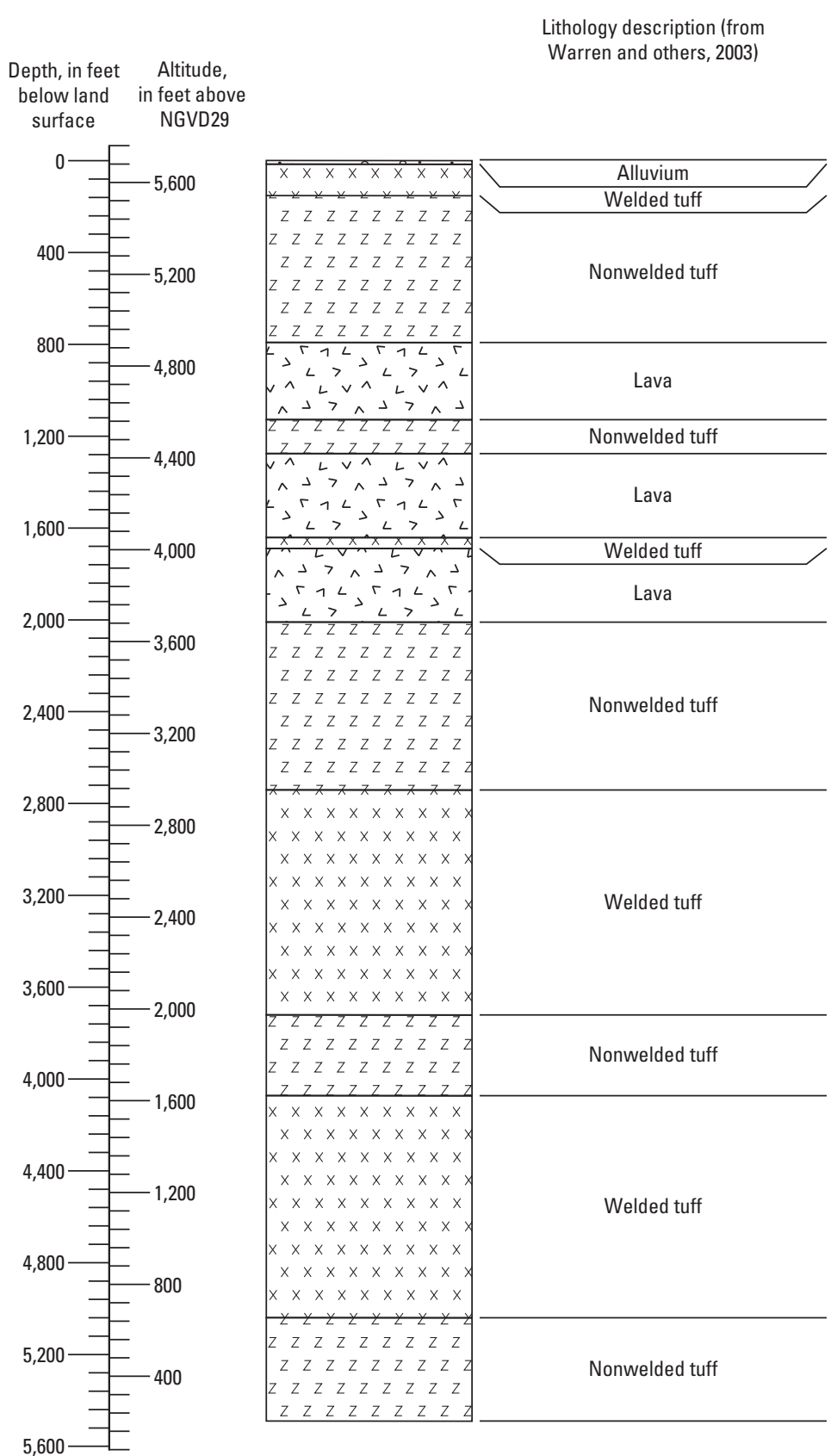

\section{EXPLANATION}

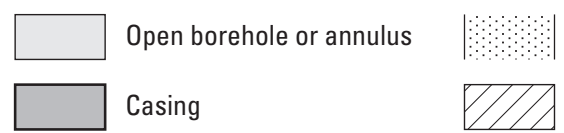

$\boldsymbol{A}$
Slotted or perforated casing

Cement, thickness of lowermost cement seal estimated
Well-construction diagram (from L.R. West and William Thordarson, U.S. Geological Suvey, written commun., 1963 Fenix \& Scisson, Inc., written commun., 1989)
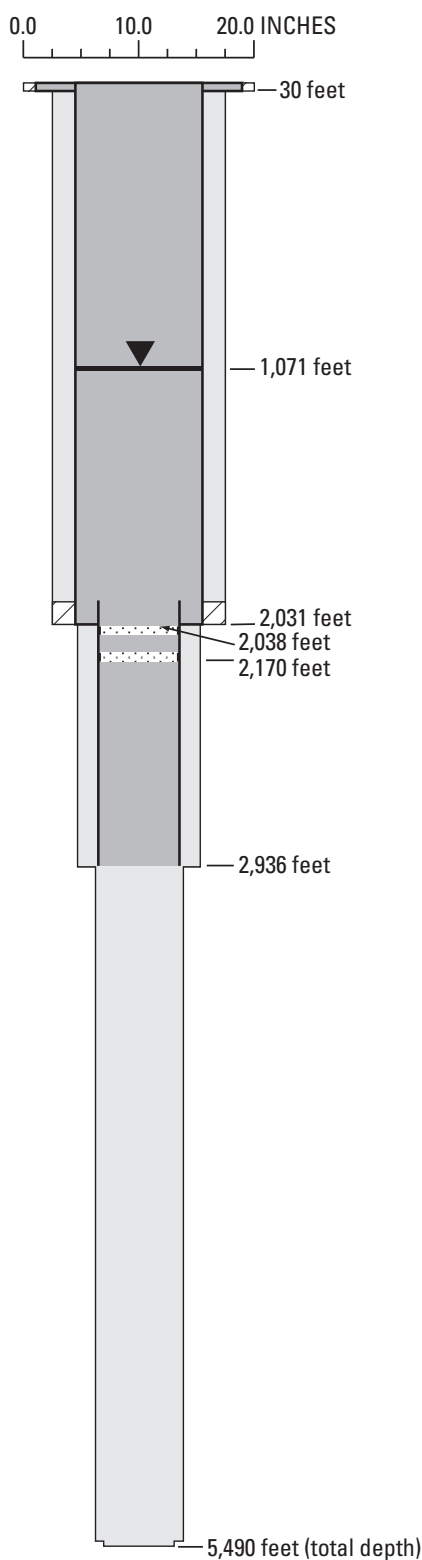

$\nabla$ Average water level

Figure 64. Borehole lithology and well construction for wells WW-8 (2031-5490 ft) and WW-8 (30-2031 ft), Area 18, Nevada National Security Site, Nye County, Nevada. 
Well name: $W W-8(30-2031 \mathrm{ft})$

USGS site identification No.: 370956116172101

Land-surface altitude: 5,695 feet above National Geodetic Vertical Datum of 1929 (NGVD29) Latitude: -

Longitude:-

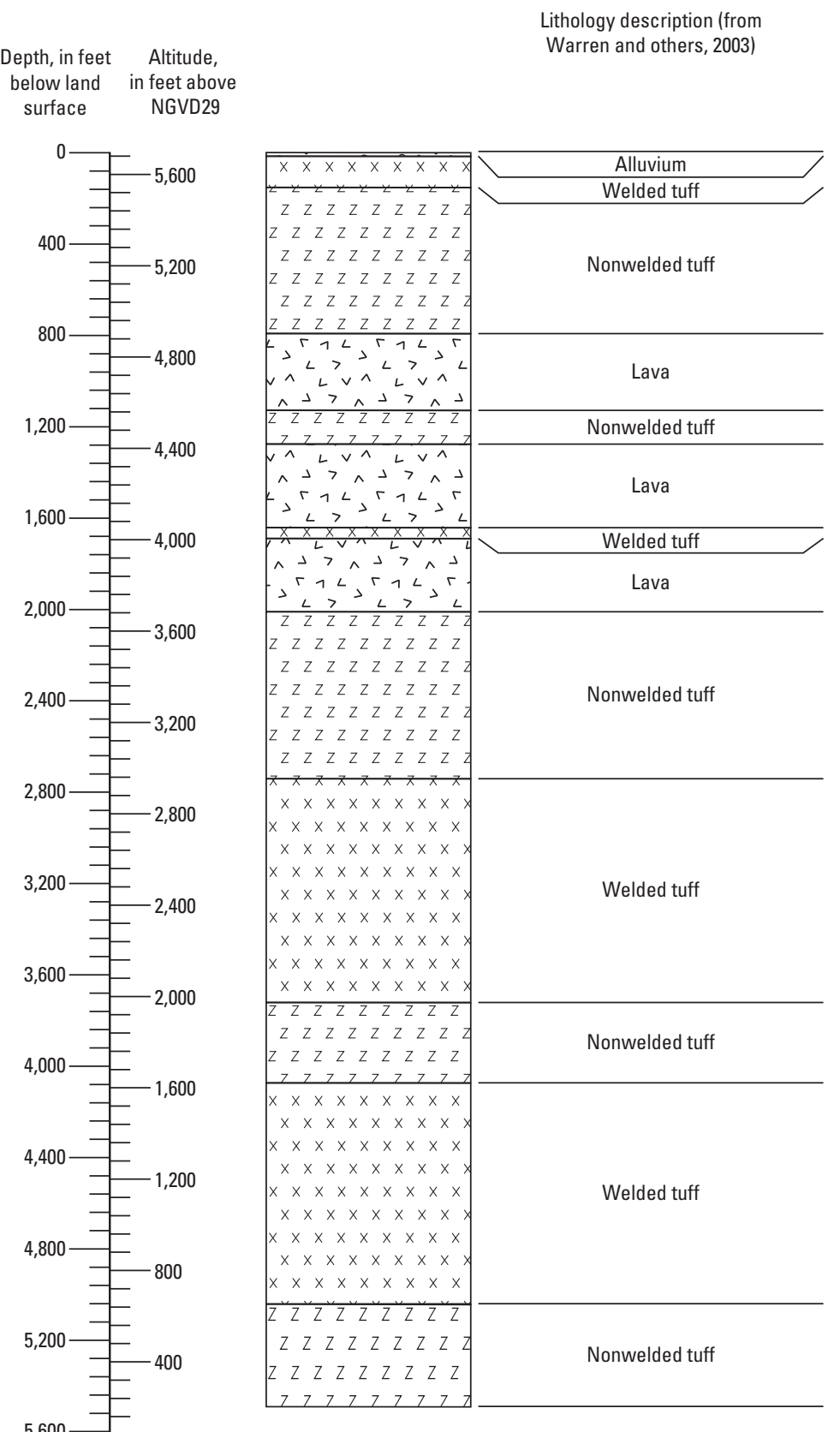

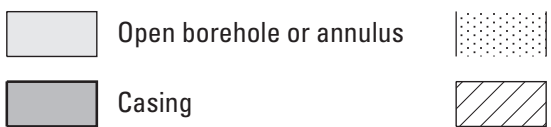

$\boldsymbol{B}$

Figure 64.-Continued.

\section{EXPLANATION}

Well-construction diagram (from L.R. West and William Thordarson, U.S. Geological Survey, written commun., 1963; Fenix \& Scisson, Inc., written commun., 1989)

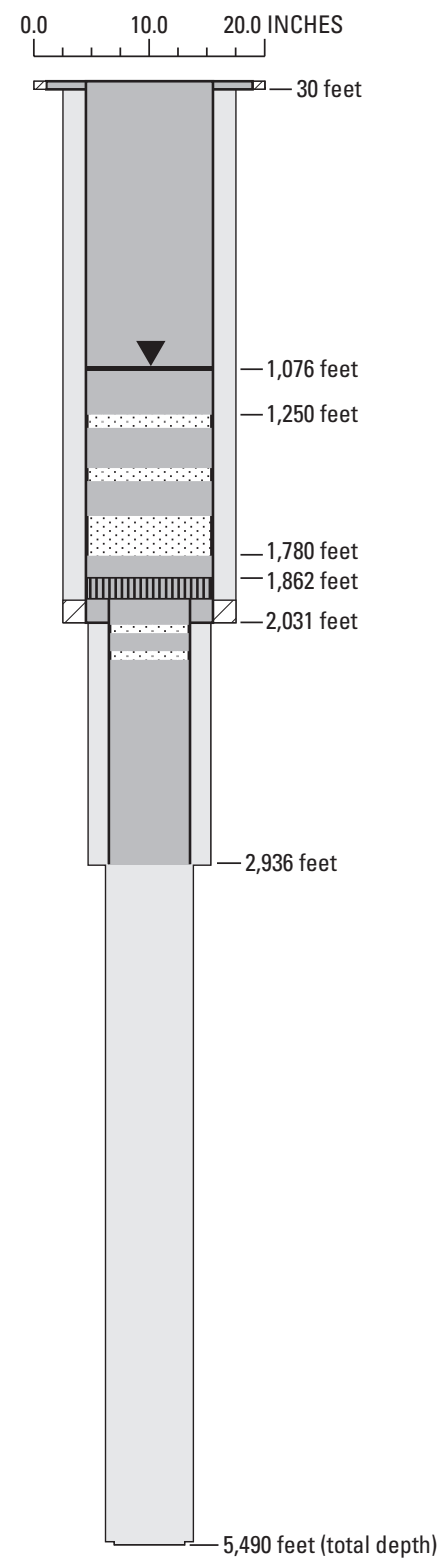

Slotted or perforated casing

Cement, thickness of lowermost cement seal estimated

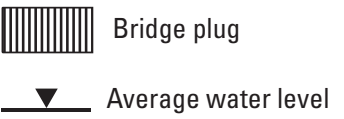



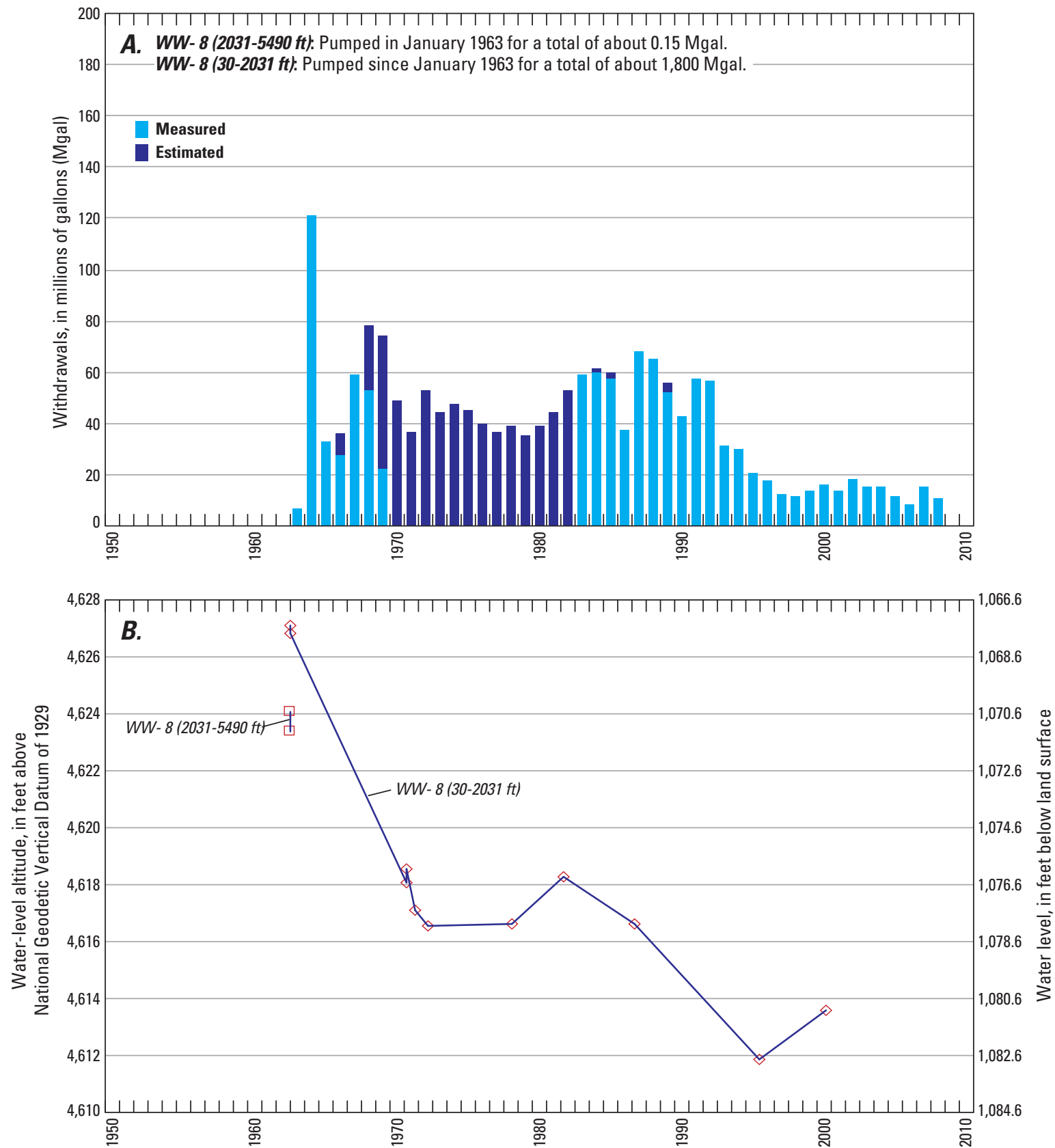

Figure 65. Annual groundwater withdrawals and water levels for wells WW-8 (2031-5490 ft) and WW-8 (30-2031 ft) Area 18, Nevada National Security Site, Nye County, Nevada, 1963-2008. 
WW-A.-WW-A is in Yucca Flat in Area 3 of the NNSS (fig. 1; table 1; WW-A photograph). Construction information for the borehole was compiled from Price and Thordarson (1961) and Bechtel Nevada (written commun., 2002). The borehole was drilled using the hydraulic-rotary and cabletool methods to a depth of 1,870 ft below land surface and completed in September 1960. During drilling of the well, the borehole deviated from vertical; at a measured hole depth of $1,870 \mathrm{ft}$, the true vertical depth is $1,847 \mathrm{ft}$. Measured (slant) depths are used when referring to well WW-A, except for water levels, which are reported as true vertical depths. Borehole diameter ranges from 16 in. at land surface to 12.25 in. at the bottom of the hole.

Borehole WW-A has one completion interval, well $W W-A$ (1870 ft), which includes casing to a depth of $1,870 \mathrm{ft}$, with a slotted interval from 1,608 to 1,870 ft (fig. 66). The annular space between the casing and borehole is open below a depth of $1,555 \mathrm{ft}$. The lithology at the saturated part of the open interval consists of alluvium (fig. 66; Wood, 2007) and thus, the well produces water from the alluvial aquifer.
WW-A originally was drilled to study groundwater movement beneath Yucca Flat (Price and Thordarson, 1961, p. 8). After completion, well $W W-A$ was pumped for a production test in September 1960, and then was used for water supply from 1961 to 1988. The well also has been part of DOE's hydrologic monitoring network since 1972 (Russell, 1989; Bechtel Nevada, 2003; U.S. Department of Energy, 2008, p. 7-6). About $882 \mathrm{Mgal}$ of water were withdrawn from the well from 1960 to 1988 (fig. 67A; appendix A). Use of the well for water supply was discontinued in 1988 (Gonzalez, 1989, p. 29).

Periodic water-level measurements made in well $W W$ - $A$ since 1960 are shown in figure $67 \mathrm{~B}$. The water levels range from about 1,600 to 1,616 ft below land surface. Water levels measured in 1960 and 1961 represent pre-pumping levels. Water levels from 1963 to 1971 show the effects of continuous pumping in the well.

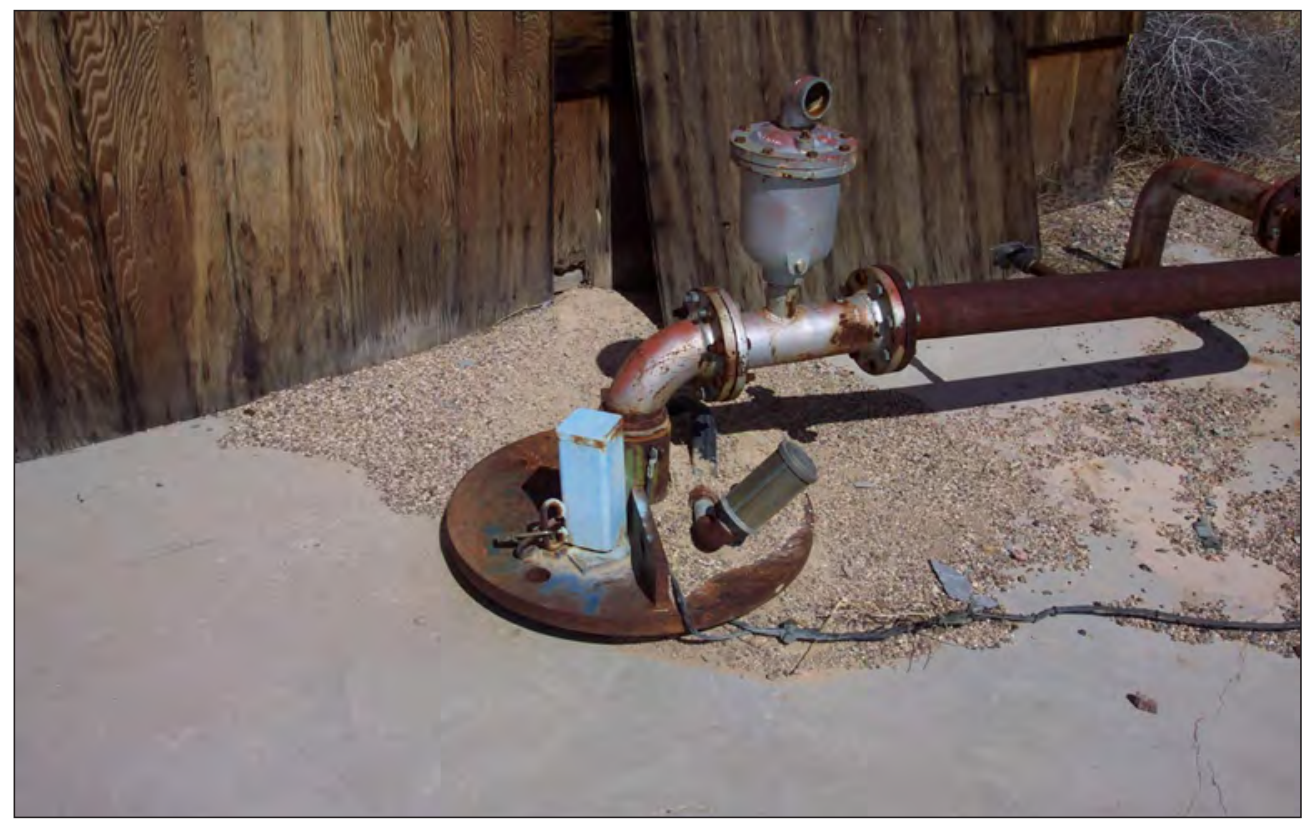

WW- A, April 2009. Photograph by Terry L. Miller, U.S. Geological Survey. 
Well name: $W W-A(1870 \mathrm{ft})$

USGS site identification No.: 370142116021101

Land-surface altitude: 4,006 feet above National Geodetic Vertical Datum of 1929 (NGVD29) Latitude:-

Longitude: -

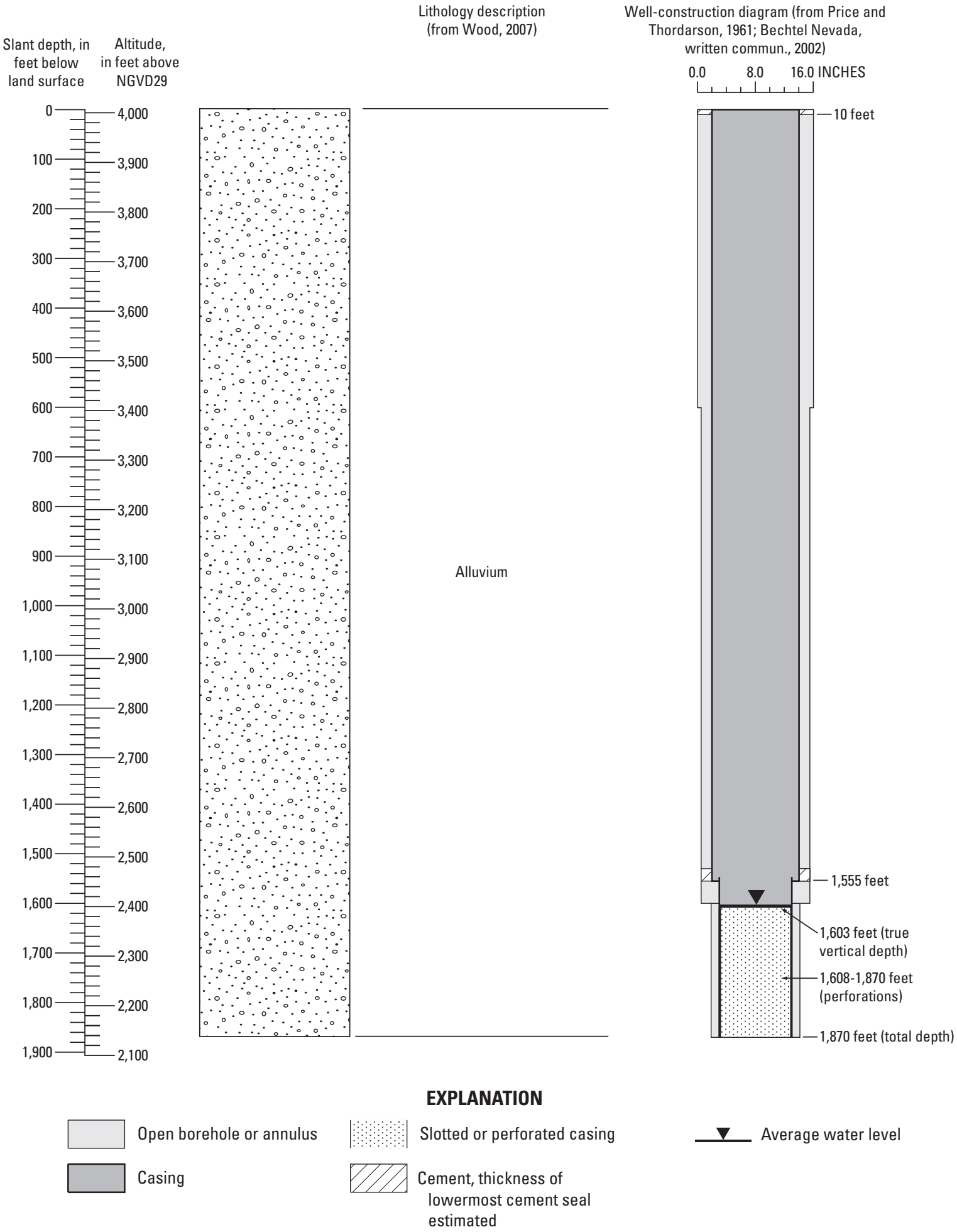

Figure 66. Borehole lithology and well construction for well $W W-A$ (1870 ft), Area 3, Nevada National Security Site, Nye County, Nevada. 

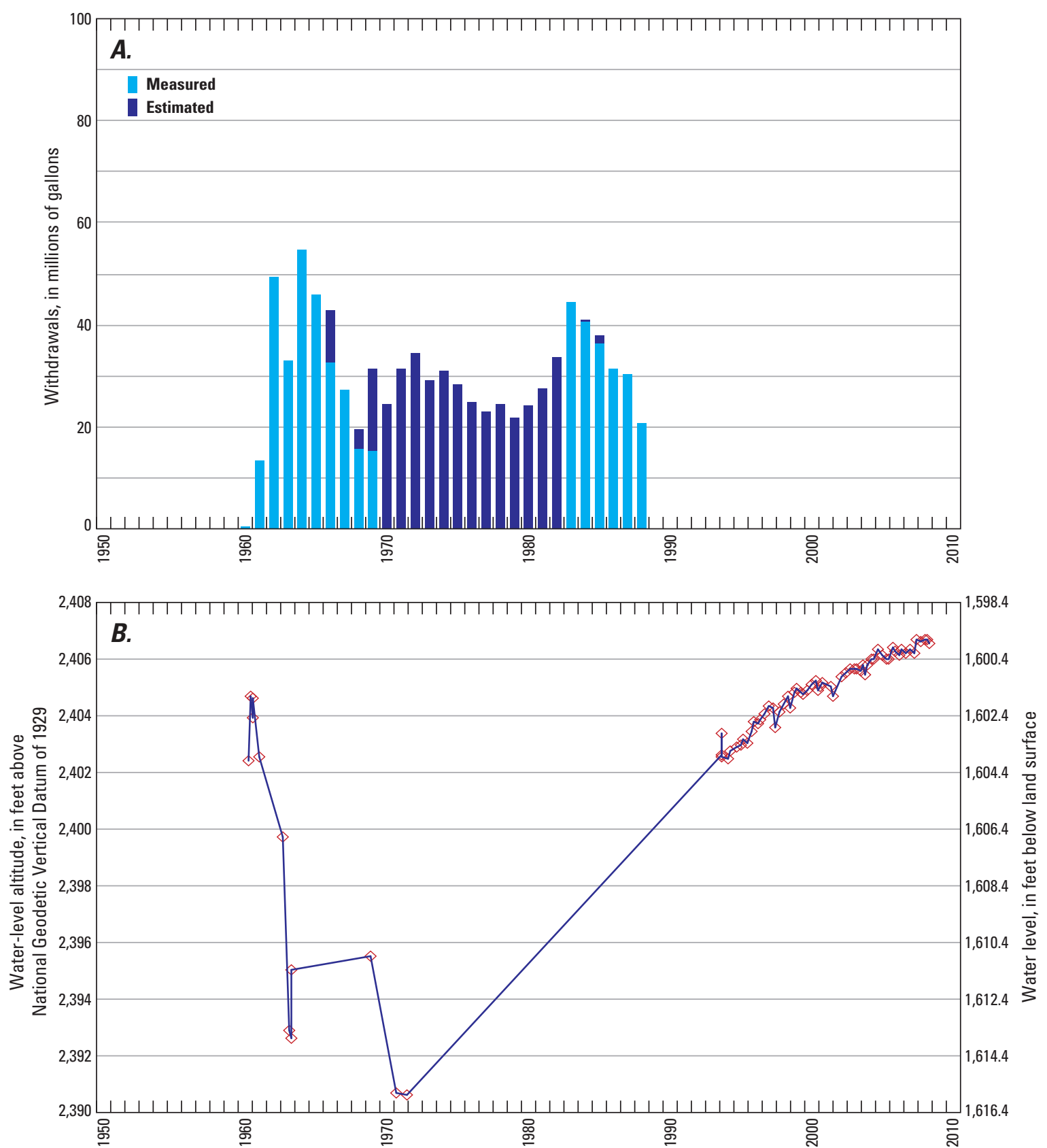

Figure 67. Annual groundwater withdrawals and water levels for well $W W-A$, Area 3, Nevada National Security Site, Nye County, Nevada, 1960-2008. 
WW-C.-WW-C is at the southern end of Yucca Flat in Area 6 of the NNSS (fig. 1; table 1; WW-C photograph). Construction information for the borehole was compiled from Fenix \& Scisson, Inc., hole history data (written commun., no date), Garber and Thordarson (1962), and Gillespie and others (1996b). The borehole was drilled to a total depth of 1,701 ft below land surface in March 1961. The borehole was drilled using the hydraulic-rotary and cable-tool methods. During drilling, the borehole deviated slightly from vertical; at a measured hole depth of $1,540 \mathrm{ft}$, the true vertical depth is 1,539.01 ft (Garber and Thordarson, 1962, p. 26). Measured (slant) depths are used when referring to WW-C, except for water levels, which are reported as true vertical depths. Borehole diameter ranges from $15 \mathrm{in}$. at land surface to $12 \mathrm{in}$. at the bottom of the hole $(1,701 \mathrm{ft})$.

Borehole WW-C has two completion intervals, well $W W-C$ (1373-1701 ft) and well WW-C (recompleted). Well $W W$ - $C$ (1373-1701 ft) represents the borehole as it was completed in March 1961. This completion includes casing to a depth of $1,701 \mathrm{ft}$, with a slotted interval from 1,571 to $1,679 \mathrm{ft}$. The annular space between the casing and borehole is open below a depth of 1,373 ft (fig. 68A). During installation of a pump in April 1961, a large amount of junk fell into the well below a depth of 1,650 ft.

Well $W W-C$ (recompleted) represents the borehole after it was under-reamed from 1,500 to $1,622 \mathrm{ft}$ extending the 15-in. borehole to a depth of 1,622 ft in April 1967. This second completion includes casing to a depth of 1,624 ft and an open borehole to $1,701 \mathrm{ft}$ (再g. 68B). The casing is slotted from 1,560 to $1,624 \mathrm{ft}$, and the annular space between the casing and borehole is open below a depth of 1,373 ft. The well currently is obstructed at a depth of about $1,624 \mathrm{ft}$. The lithology at the saturated part of the open interval in both wells is limestone (fig. 68B; Warren and others, 2003), which produces water mostly from fractures (Garber and Thordarson, 1962, p. 27; Winograd and Thordarson, 1975, table 3, see well 79-69a).

WW-C originally was drilled to study the movement of groundwater beneath Yucca Flat (Garber and Thordarson, 1962, p. 3), and later was used for water supply (Russell, 1989, p. 26). WW-C also was part of DOE's hydrologic monitoring network from 1972 to 1995 (Russell, 1989; Black and Townsend, 1996, table 9.5). Almost 1,300 Mgal of water were withdrawn from the borehole from 1961 to 1995. (fig. 69A; appendix A). Well WW-C (1373-1701 ft) was pumped from September 1961 to September 1966 for a total of about 210 Mgal. Groundwater withdrawals from well WW-C (recompleted) were estimated to be about 1,070 Mgal during pumping from May 1967 to July 1995.

Periodic water-level measurements made in WW-C are shown in figure $69 \mathrm{~B}$. The water levels range from about 1,539 to $1,545 \mathrm{ft}$ below land surface in well $W W-C(1373-1701 \mathrm{ft})$, and 1,541 to $1,544 \mathrm{ft}$ below land surface in well $W W-C$ (recompleted). The first two water levels in well WW-C (1373$1701 \mathrm{ft}$ ) were measured prior to the start of pumping, however, all water levels measured in the well during 1961 to 1962 are somewhat erratic. Water levels measured in well $W W-C$ (recompleted) from 1969 to 1975 show the effects of pumping in the well. The nearby well $W W-C-1$, which is about $100 \mathrm{ft}$ southeast of WW-C, also was pumped during 1962-75.

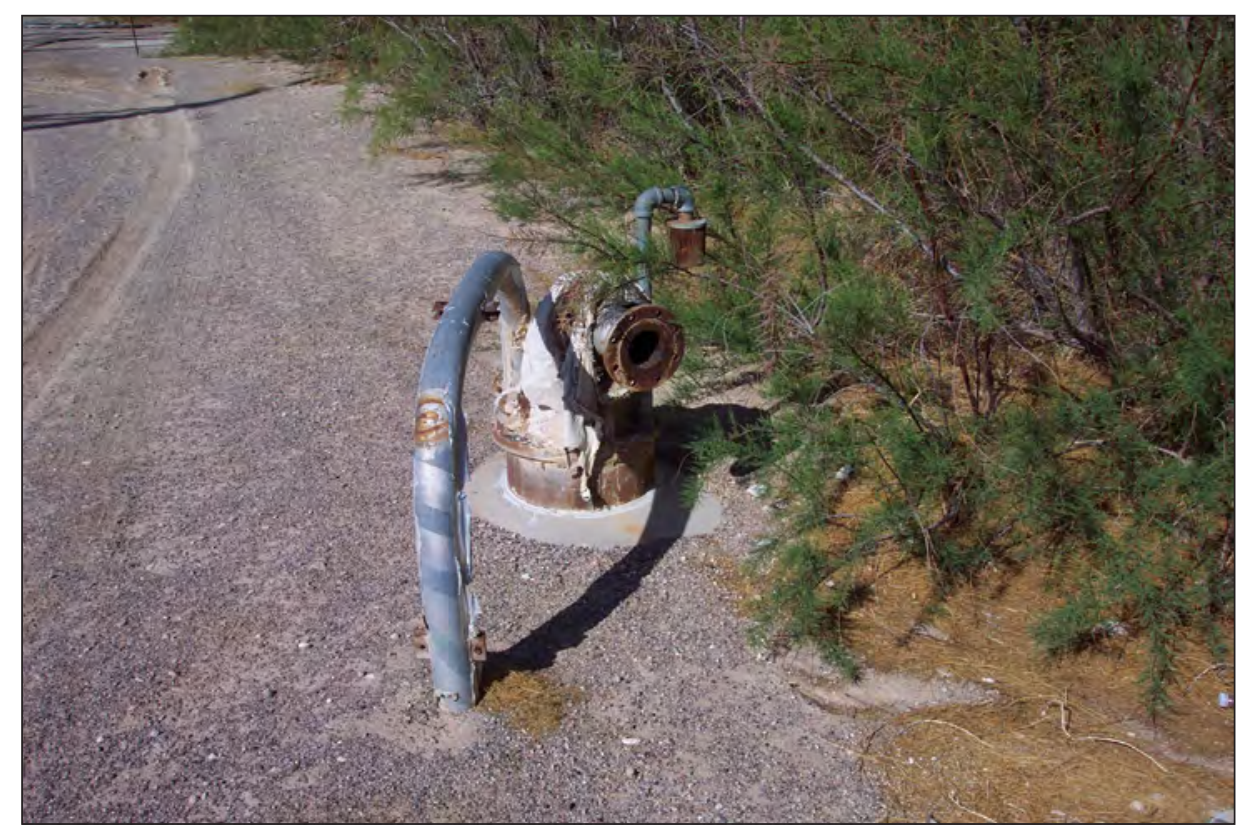

WW- C, April 2009. Photograph by Terry L. Miller, U.S. Geological Survey. 
Well name: $W W-C(1373-1701 \mathrm{ft})$

USGS site identification No.: 365508116003501

Land-surface altitude: 3,924 feet above National Geodetic Vertical Datum of 1929 (NGVD29) Latitude:-

Longitude: -

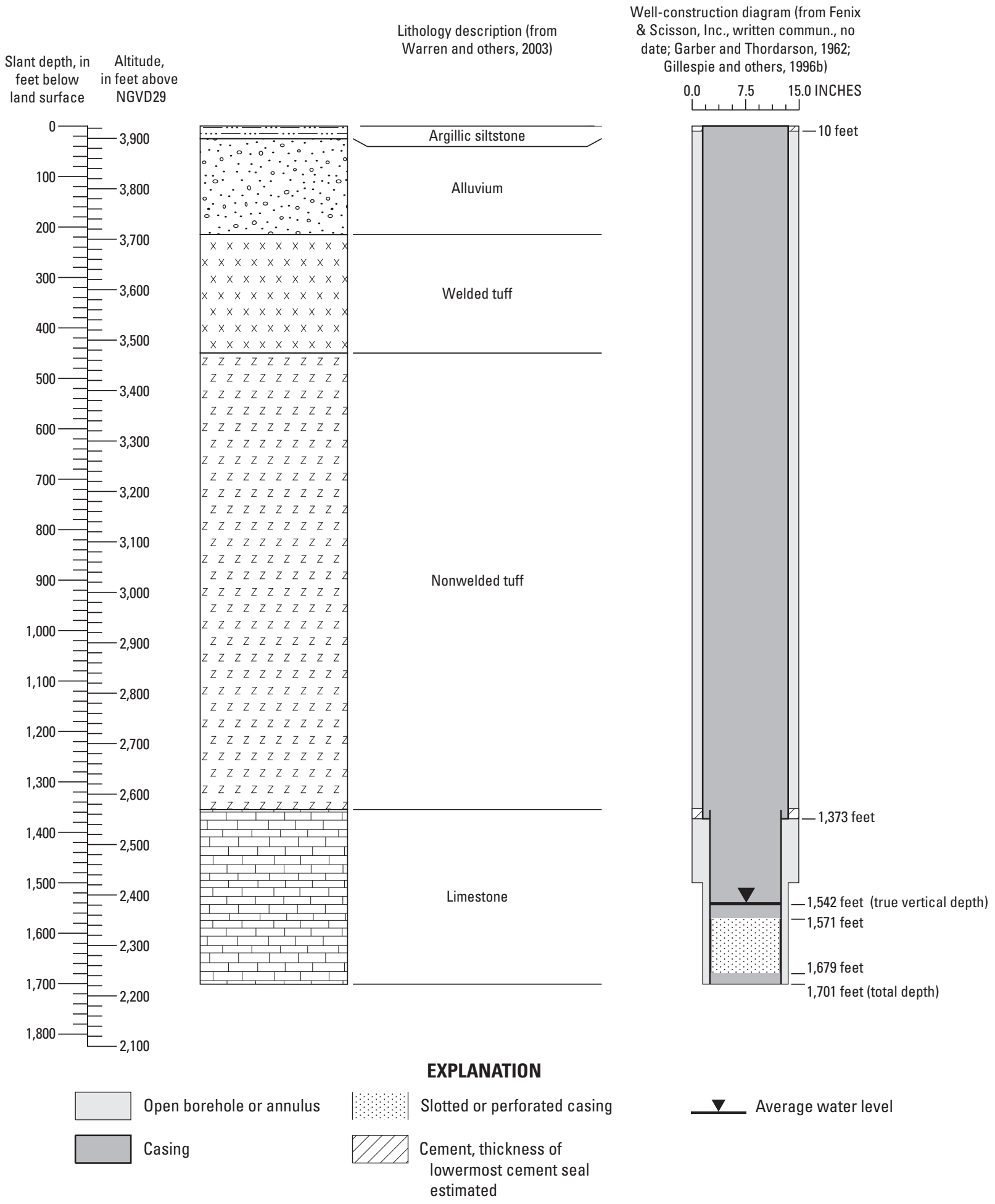

Figure 68. Borehole lithology and well construction for wells $W W-C$ (1373-1701 ft) and WW-C (recompleted), Area 6, Nevada National Security Site, Nye County, Nevada. 
Well name: WW-C (recompleted)

USGS site identification No.: 365508116003502

Land-surface altitude: 3,924 feet above National Geodetic Vertical Datum of 1929 (NGVD29)

Latitude:-

Longitude:-

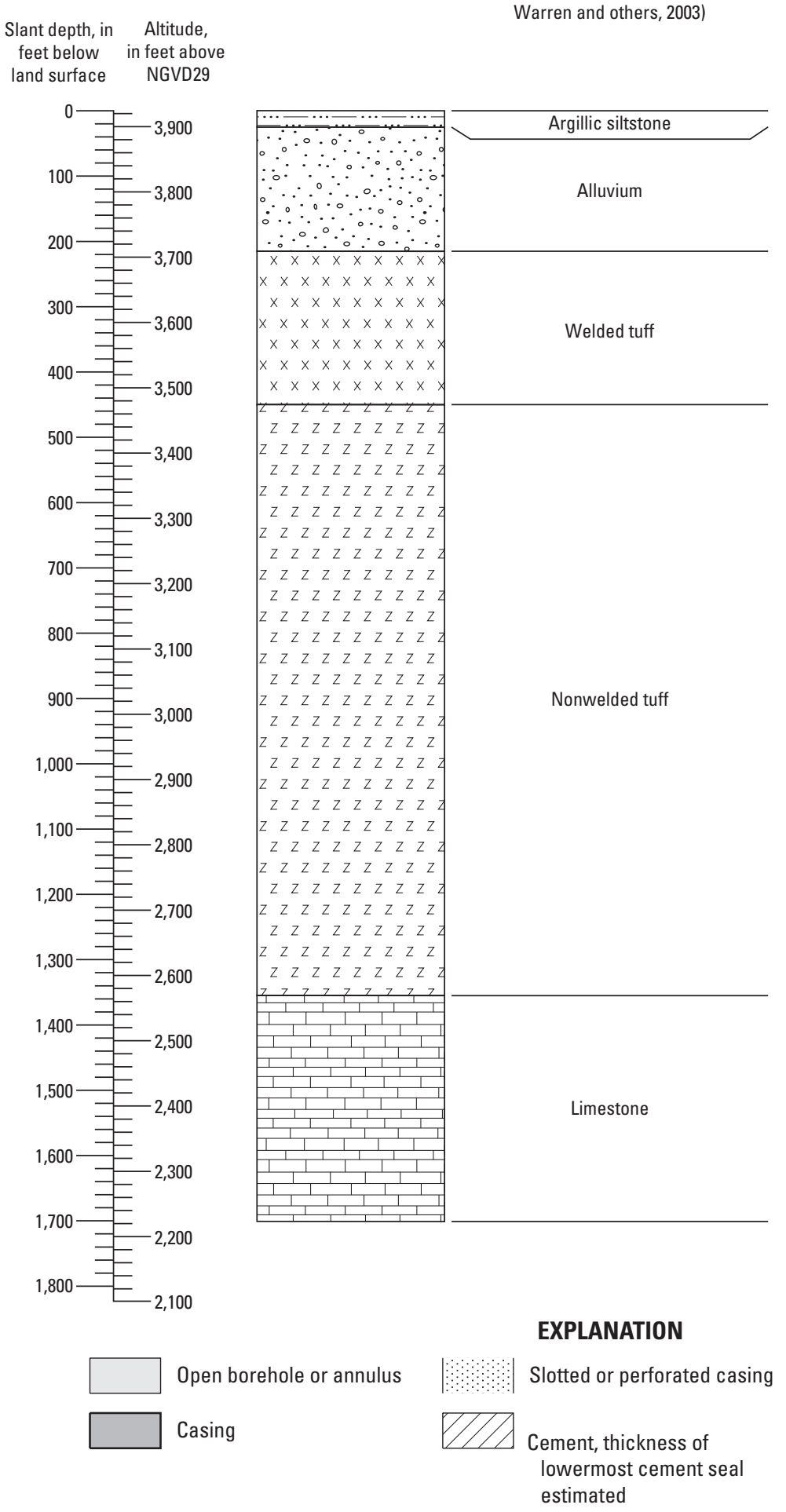

Well-construction diagram (from Fenix \&

Scisson, Inc., written commun., no date;

Garber and Thordarson, 1962; Gillespie and others, 1996b)
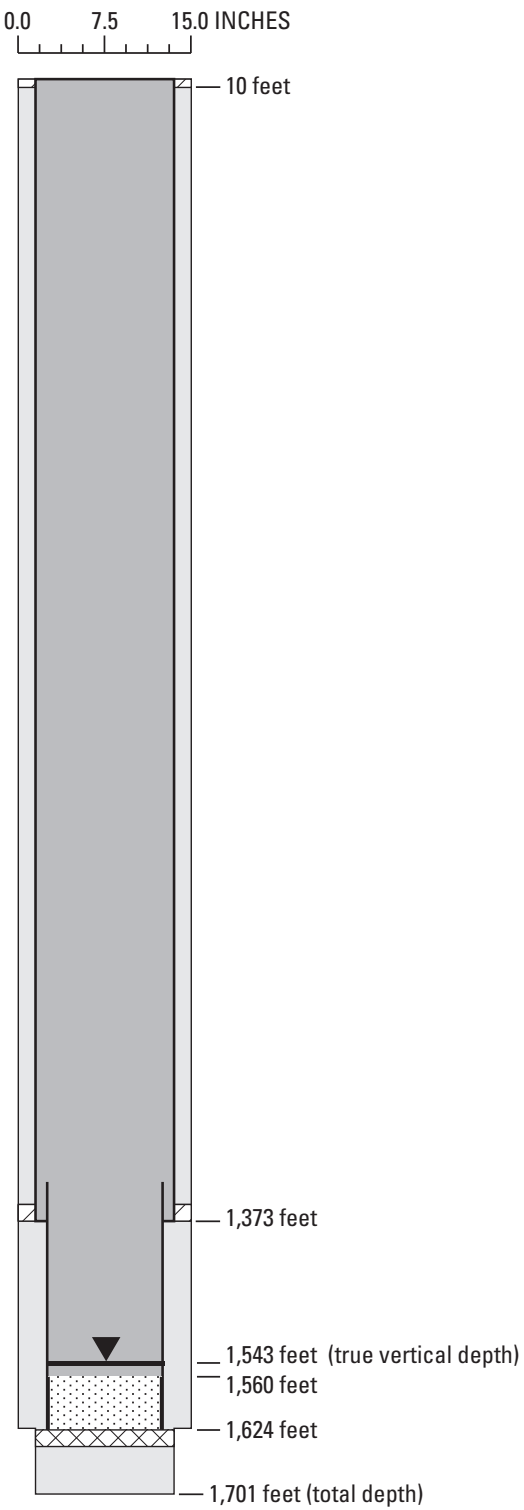

$\boldsymbol{B}$

estimated

Figure 68.-Continued. 

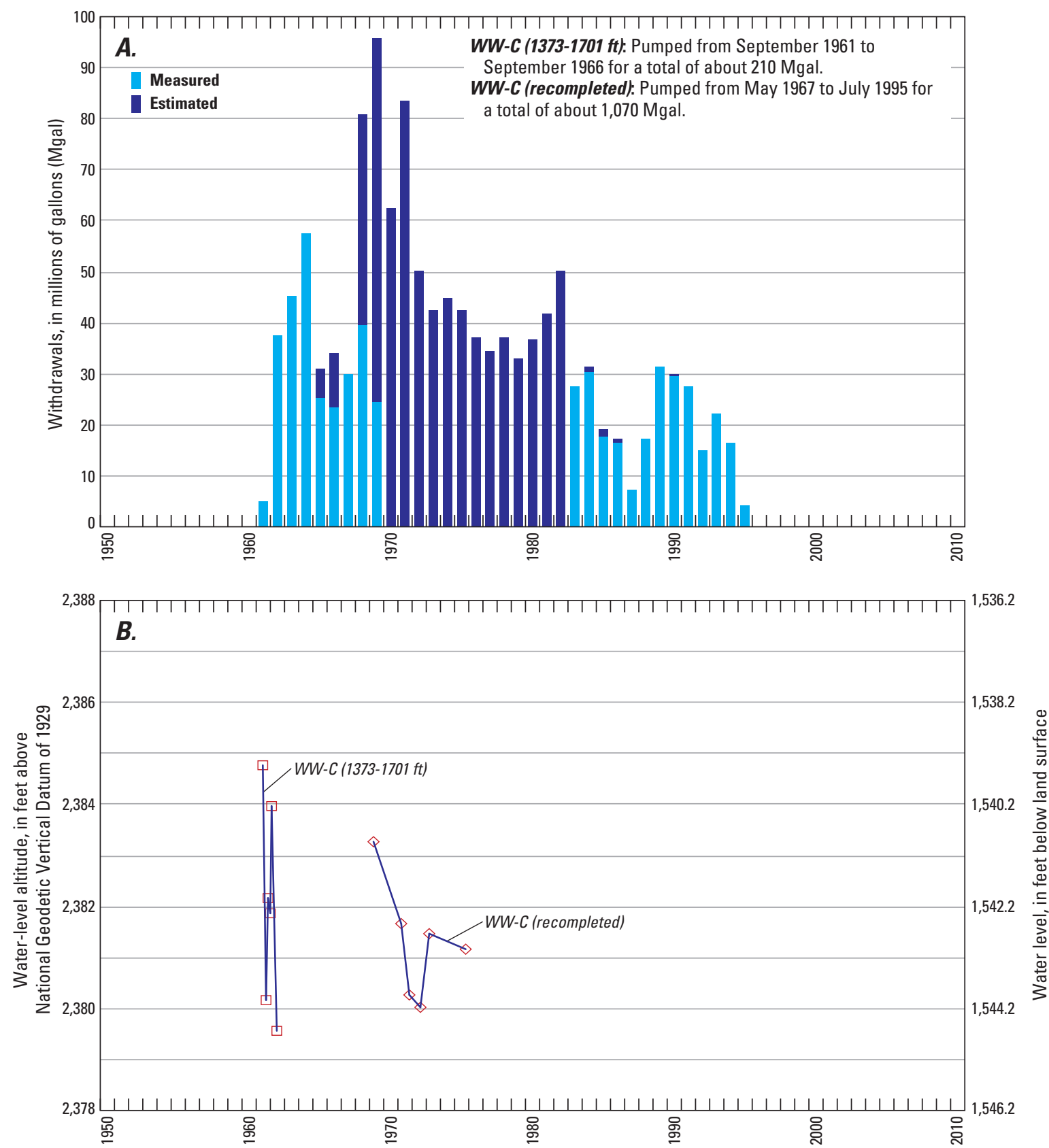

Figure 69. Annual groundwater withdrawals and water levels for wells $W W-C$ (1373-1701 ft) and WW-C (recompleted), Area 6, Nevada National Security Site, Nye County, Nevada, 1961-95. 
WW-C-1.-WW-C-1 is at the southern end of Yucca Flat in Area 6 of the NNSS (fig. 1; table 1; WW-C-1 photograph). Construction information for the borehole was compiled from Thordarson and others (1967), and Fenix \& Scisson, Inc., hole history data (written commun., 1989). The borehole was drilled using standard-rotary and cable-tool methods to a depth of 1,707 ft below land surface in April 1962. The borehole was sidetracked at 1,389 ft and drilled to a depth of 1,650 ft and completed in June 1962. In the sidetracked borehole, the deviation is 9 degrees at a measured borehole depth of 1,622 ft. Measured (slant) depths are used when referring to WW-C1 , except for water levels, which are reported as true vertical depths. Diameter of the borehole ranges from at least 54 in. at land surface to $22 \mathrm{in}$. at the bottom of the sidetracked hole $(1,650 \mathrm{ft})$.

Borehole WW-C-1 has a single completion interval, well $W W-C-1$, which represents the original borehole to a depth of 1,389 ft and the sidetracked hole to a depth of $1,650 \mathrm{ft}$ (fig. 70). The well contains casing to a depth of 1,650 ft with perforations from 1,536 to $1,650 \mathrm{ft}$. The annular space between the casing and borehole is open below a depth of $914 \mathrm{ft}$ (fig. 70). The lithology at the saturated part of the open interval is limestone (fig. 70; Wood, 2007). Water in the well originates from the limestone, specifically the interval from 1,607 to 1,623 ft (Winograd and Thordarson, 1975, table 3, see well 79-69).

WW-C-1 was drilled as a water-supply well (Thordarson and others, 1967, p.16; Russell, 1989, p. 26), and also has been part of DOE's hydrologic monitoring network since 1973 (Russell, 1989; Bechtel Nevada, 2003; U.S. Department of Energy, 2008, p. 7-6). Pumping in well $W W-C-1$ began in 1962 and has been nearly continuous since then. About 1,140 Mgal of water have been withdrawn from the well since June 1962 (fig. 71A; appendix A).

Periodic water-level measurements made in well $\mathrm{WW}$ $C$-1 from 1963 to 1998 are shown in figure $71 B$. The water levels range from about 1,538 to $1,540 \mathrm{ft}$ below land surface. Water levels were measured after continuous pumping began in the well. The nearby borehole WW-C, which is about $100 \mathrm{ft}$ northwest of WW-C-1, also was pumped from 1961 to 1995.

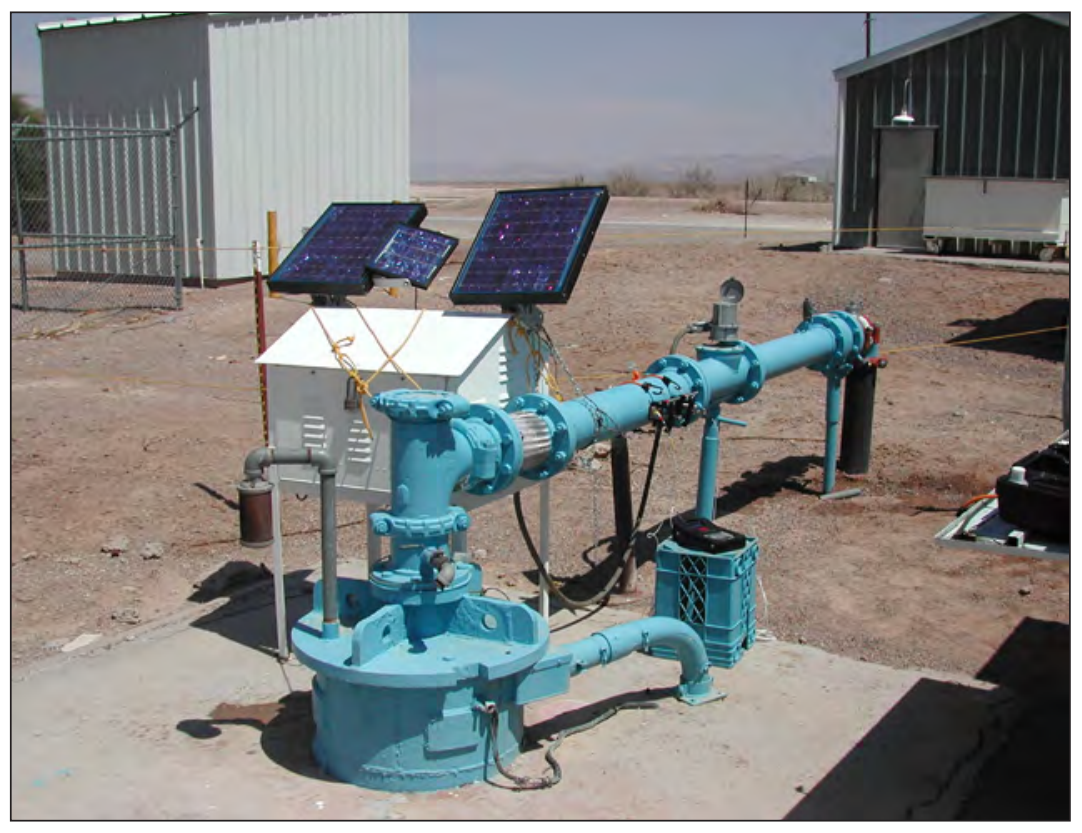

WW- C-1, July 2002. Photograph by Richard J. La Camera, U.S. Geological Survey. 
Well name: $W W-C-1$

USGS site identification No.: 365500116003901

Land-surface altitude: 3,924 feet above National Geodetic Vertical Datum of 1929 (NGVD29) Latitude: -

Longitude:-

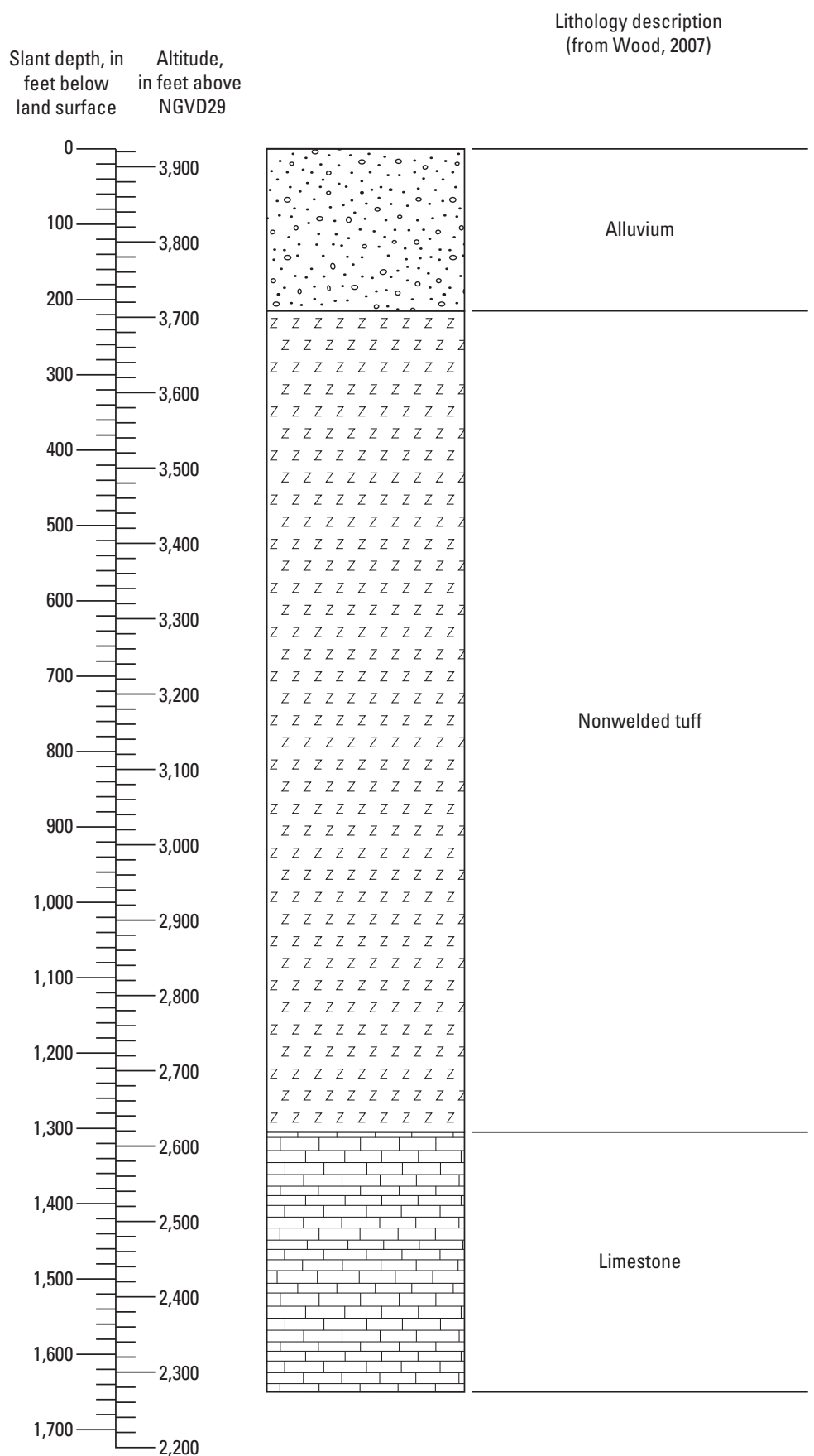

\section{EXPLANATION}

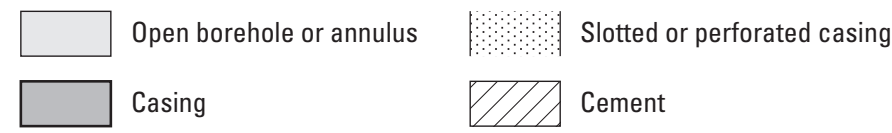

Well-construction diagram (from Thordarson and others, 1967; Fenix \& Scisson, Inc., written commun., 1989)

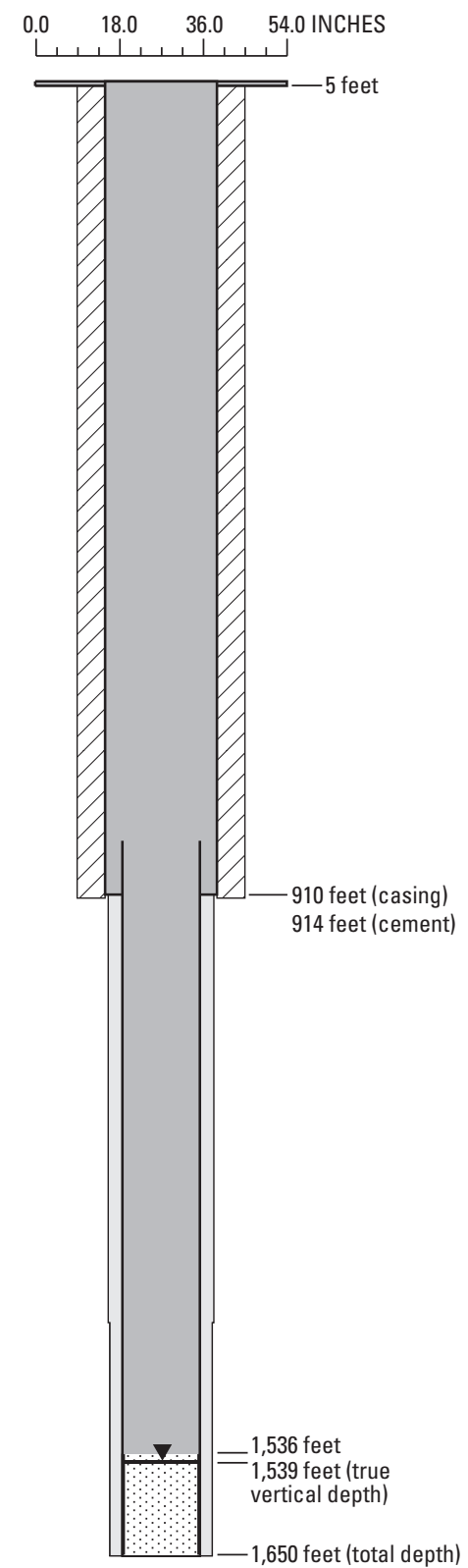

$-1,650$ feet (total depth)

$\nabla \quad$ Average water level

Figure 70. Borehole lithology and well construction for well WW-C-1, Area 6, Nevada National Security Site, Nye County, Nevada. 

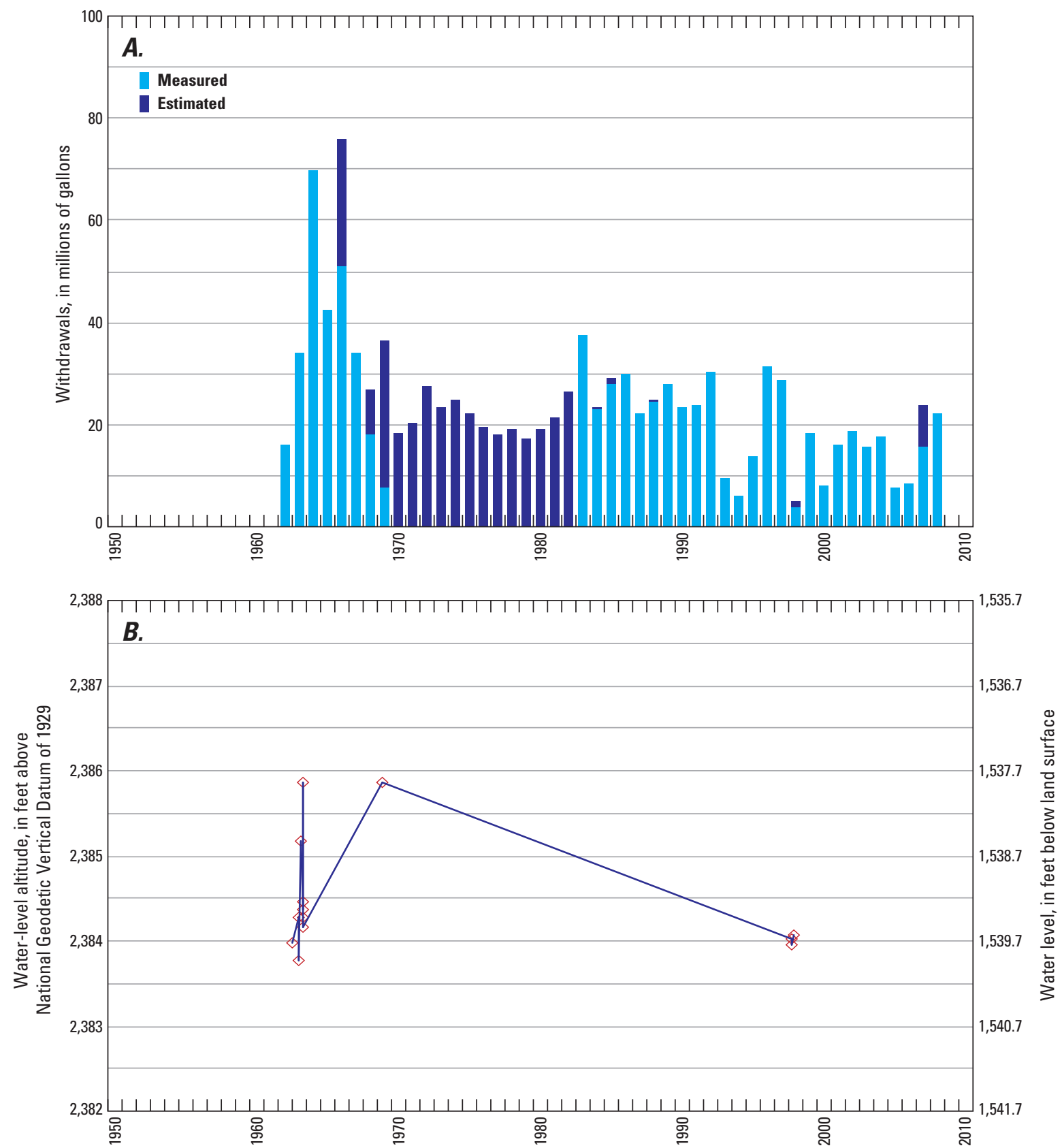

Figure 71. Annual groundwater withdrawals and water levels for well WW-C-1, Area 6, Nevada National Security Site, Nye County, Nevada, 1962-2008. 


\section{Acknowledgments}

This study was funded by the U.S. Department of Energy under Interagency Agreement DE-A152-07NA28100. The authors wish to thank employees of Reynolds Electrical \& Engineering Co., Inc. (REECo), Bechtel Nevada, and National Security Technologies, LLC (NSTec), who collected and provided most of the groundwater withdrawal data compiled in the Microsoft ${ }^{\circledR}$ Excel spreadsheet in appendix A, and the various other Federal agencies that provided groundwater withdrawal data also included in the spreadsheet. Appreciation is extended to USGS personnel David B. Wood for development of the original groundwater withdrawal spreadsheet, Joseph M. Fenelon and Randell J. Laczniak (retired) for guidance on further development of the spreadsheet and aspects of the report, and Keith J. Halford for creating a user interface in the spreadsheet to access and view the groundwater withdrawal data.

\section{References Cited}

Bechtel Nevada, 2003, Routine radiological environmental monitoring plan: Las Vegas, Nev., Report DOE/NV/11718804 prepared for the U.S. Department of Energy, National Nuclear Security Administration Nevada Site Office [variously paged].

Bechtel Nevada, 2004, Completion report for well cluster ER-6-1: Las Vegas, Nev., Report DOE/NV/11718-862 prepared for the U.S. Department of Energy, National Nuclear Security Administration Nevada Site Office [variously paged].

Black, S.C., Glines, W.M., and Townsend, Y.E., eds., 1995, Nevada Test Site annual site environmental report for calendar year - 1994: Reynolds Electrical \& Engineering Co., Inc., Report DOE/NV/11432-175 UC-600 prepared for the U.S. Department of Energy, Nevada Operations Office [variously paged].

Black, S.C., and Townsend, Y.E., eds., 1996, Nevada Test Site annual site environmental report for calendar year - 1995: Bechtel Nevada, Report DOE/NV/11718-037 UC-600 prepared for the U.S. Department of Energy, Nevada Operations Office [variously paged].

Blankennagel, R.K., 1968, Geophysical logging and hydraulic testing, Pahute Mesa, Nevada Test Site: Groundwater, v. 6, no. 4, p. 24-31.

Blankennagel, R.K., and Weir, J.E., Jr., 1973, Geohydrology of the eastern part of Pahute Mesa, Nevada Test Site, Nye County, Nevada: U.S. Geological Survey Professional Paper 712-B, 35 p.
Bryant, E.A., 1992, The Cambric migration experiment-A summary report: Los Alamos National Laboratory Report LA-12335-MS, $37 \mathrm{p}$.

Buddemeier, R.W., and Isherwood, Dana, 1985, Radionuclide migration project, 1984 progress report: Lawrence Livermore National Laboratory Report UCRL-53628, 71 p.

Burns \& McDonnell Engineering Company, 1959, Report on development of wells J-11 \& J-12, Jackass Flats, Nye County, Nevada: Kansas City, Missouri, Burns \& McDonnell Engineering Company Report, 56-16D [variously paged].

Cardinalli, J.L., Roach, L.M., Rush, F.E., and Vasey, B.J., 1968, State of Nevada hydrographic areas: Nevada Division of Water Resources map, scale 1:500,000.

Claassen, H.C., 1973, Water quality and physical characteristics of Nevada Test Site water-supply wells: U.S. Geological Survey Report USGS-474-158 [NTS-242], 145 p. Available only from National Technical Information Service, U.S. Department of Commerce, Alexandria, Virginia 22312.

Culham, H.W., Eaton, G.F., Genetti, V., Hu, Q., Kersting, A.B., Lindvall, R.E., Moran, J.E., Blasiyh Nuño, G.A., Powell, B.A., Rose, T.P., Singleton, M.J., Williams, R.W., Zavarin, M., and Zhao, P., 2008, Hydrologic Resources Management Program and Underground Test Area Project, FY 2006 progress report: Lawrence Livermore National Laboratory Report LLNL-TR-404620, 83 p.

Davisson, M.L., Eaton, G.F., Hakem, N.L., Hudson, G.B., Hutcheon, I.D., Laue, C.A., Kersting, A.B., Kenneally, J.M., Moran, J.E., Phinney, D.L., Rose, T.P., Smith, D.K., Sylwester, E.R., Wang, L., Williams, R., and Zavarin, M., 2001, Hydrologic Resources Management Program and Underground Test Area Project, FY2000 progress report: Lawrence Livermore National Laboratory Report UCRL-ID-145167, 27 p.

Dinwiddie, G.A., and Weir, J.E., Jr., 1979, Summary of hydraulic tests and hydrologic data for holes UE16d and UE16f, Syncline Ridge area, Nevada Test Site: U.S. Geological Survey Report USGS-1543-3, 25 p.

Doyle, A.C., and Meyer, G.L., 1963, Summary of hydraulic data and abridged lithologic log of ground-water Test Well 6 (J-13), Jackass Flats, Nevada Test Site, Nye County, Nevada: U.S. Geological Survey Open-File Report 474-314, $11 \mathrm{p}$.

Fenelon, J.M., 2000, Quality assurance and analysis of water levels in wells on Pahute Mesa and vicinity, Nevada Test Site, Nye County, Nevada: U.S. Geological Survey WaterResources Investigations Report 00-4014, 68 p. 
Fenelon, J.M., 2005, Analysis of ground-water levels and associated trends in Yucca Flat, Nevada Test Site, Nye County, Nevada, 1951-2003: U.S. Geological Survey Scientific Investigations Report 2005-5175, 87 p.

Fenelon, J.M., and Moreo, M.T., 2002, Trend analysis of ground-water levels and spring discharge in the Yucca Mountain region, Nevada and California, 1960-2000: U.S. Geological Survey Water-Resources Investigations Report 02-4178, 97 p.

Fenelon, J.M., Sweetkind, D.S., and Laczniak, R.J., 2010, Groundwater flow systems at the Nevada Test Site, Nevada: A synthesis of potentiometric contours, hydrostratigraphy, and geologic structures: U.S. Geological Survey Professional Paper 1771, 53 p.

Fenneman, N.M., 1931, Physiography of western United States: New York, McGraw-Hill Book Company, Inc., $534 \mathrm{p}$.

Garber, M.S., and Thordarson, William, 1962, Ground water test well C, Nevada Test Site, Nye County, Nevada: U.S. Geological Survey Open-File Report 62-50, 79 p.

Geldon, A.L., 1993, Preliminary hydrogeologic assessment of boreholes UE-25c \#1, UE-25c \#2, and UE-25c \#3, Yucca Mountain, Nye County, Nevada: U.S. Geological Survey Water-Resources Investigations Report 92-4016, 85 p.

Geldon, A.L., 1996, Results and interpretation of preliminary aquifer tests in boreholes UE-25c \#1, UE-25c \#2, and UE-25c \#3, Yucca Mountain, Nye County, Nevada: U.S. Geological Survey Water-Resources Investigations Report 94-4177, 119 p.

Geldon, A.L., Umari, A.M.A., Earle, J.D., Fahy, M.F., Gemmell, J.M., and Darnell, Jon, 1998, Analysis of a multiple-well interference test in Miocene tuffaceous rocks at the C-hole complex, May-June 1995, Yucca Mountain, Nye County, Nevada: U.S. Geological Survey WaterResources Investigations Report 97-4166, 33 p.

Geldon, A.L., Umari, A.M.A., Fahy, M.F., Earle, J.D., Gemmell, J.M., and Darnell, Jon, 2002, Results of hydraulic tests in Miocene tuffaceous rocks at the C-hole complex, 1995 to 1997, Yucca Mountain, Nye County, Nevada: U.S. Geological Survey Water-Resources Investigations Report 02-4141, 58 p.

Gillespie, David, Donithan, Dee, and Seaber, Paul, 1996a, Evaluation of existing wells at the Nevada Test Site for plugging and abandonment or for recompletion as monitoring wells: Desert Research Institute Publication 45153, DOE/NV/11508-21, UC-703, 125 p.

Gillespie, David, Donithan, Dee, and Seaber, Paul, 1996b, Nevada Test Site water-supply wells: Desert Research Institute Publication 45138, 68 p.
Gonzalez, D.A., 1989, Onsite environmental report for the Nevada Test Site (January 1988 through December 1988): Reynolds Electrical \& Engineering Co., Inc., Report DOE/ NV/10630-8 prepared for the U.S. Department of Energy, Nevada Operations Office, 234 p.

Hood, J.W., 1961, Water wells in Frenchman and Yucca Valleys, Nevada Test Site, Nye County, Nevada: U.S. Geological Survey Open-File Report 61-68, 60 p.

Houghton, J.G., Sakamoto, C.M., and Gifford, R.O., 1975, Nevada's weather and climate: Nevada Bureau of Mines and Geology Special Publication 2, 78 p.

La Camera, R.J., and Westenburg, C.L., 1994, Selected ground-water data for Yucca Mountain region, southern Nevada and eastern California, through December 1992: U.S. Geological Survey Open-File Report 94-54, 161 p.

Laczniak, R.J., Cole, J.C., Sawyer, D.A., and Trudeau, D.A., 1996, Summary of hydrogeologic controls on groundwater flow at the Nevada Test Site, Nye County, Nevada: U.S. Geological Survey Water-Resources Investigations Report 96-4109, 59 p.

Lyles, B.F., 1990, Tritium variations in groundwater on the Nevada Test Site: Desert Research Institute Publication 45086, 85 p.

Lyles, B.F., 1993, Tritium activities in selected wells on the Nevada Test Site: Desert Research Institute Publication 45104, 16 p.

Moore, J.E., 1961, Records of wells, test holes, and springs in the Nevada Test Site and surrounding area: U.S. Geological Survey Open-File Report 61-106, 22 p.

Moore, J.E., 1962, Selected logs and drilling records of wells and test holes drilled at the Nevada Test Site prior to 1960: U.S. Geological Survey Open-File Report 62-87, 54 p.

Moore, J.E., Doyle, A.C., Walker, G.E., and Young, R.A., 1963, Ground water Test Well 2, Nevada Test Site, Nye County, Nevada: U.S. Geological Survey Open-File Report 63-101, 73 p.

Moreo, M.T., Halford, K.J., La Camera, R.J., and Laczniak, R.J., 2003, Estimated ground-water withdrawals from the Death Valley regional flow system, Nevada and California, 1913-98: Water-Resources Investigations Report 03-4245, $28 \mathrm{p}$.

Nevada Department of Conservation and Natural Resources, Water words dictionary: Nevada Department of Conservation and Natural Resources, Division of Water Resources, accessed December 1, 2009 at URL http://water. nv.gov/WaterPlanning/dict-1/ww-index.cfm. 
Pawloski, G.A., 1982, Results from exploratory drill hole UE2ce, northwest Yucca Flat, Nevada Test Site, near the Nash Event: Lawrence Livermore Laboratory Report UCID-19324, 20 p.

Price, C.E., and Thordarson, William, 1961, Ground water test well A, Nevada Test Site, Nye County, Nevada: A summary of lithologic data, aquifer tests, and construction: U.S. Geological Survey Trace Elements Investigations Report 800, 60 p.

Reiner, S.R., Locke, G.L., and Robie, L.S., 1995, Groundwater data for the Nevada Test Site and selected other areas in south-central Nevada, 1992-93: U.S. Geological Survey Open-File Report 95-160, 38 p.

Robie, L.S., Reiner, S.R., and Locke, G.L., 1995, Groundwater data for the Nevada Test Site, 1992, and for selected other areas in south-central Nevada, 1952-92: U.S. Geological Survey Open-File Report 95-284, 48 p.

Robison, J.H., Stephens, D.M., Luckey, R.R., and Baldwin, D.A., 1988, Water levels in periodically measured wells in the Yucca Mountain area, Nevada, 1981-87: U.S. Geological Survey Open-File Report 88-468, 132 p.

Rush, F.E., 1968, Index of hydrographic areas in Nevada: Nevada Division of Water Resources Information Report 6, $38 \mathrm{p}$.

Russell, C.E., 1989, Assessment of the Nevada Test Site monitoring well system: Desert Research Institute Publication 45072, 46 p.

Sawyer, D.A., Thompson, J.L., and Smith, D.K., 1999, The CHESHIRE migration experiment-A summary report: Los Alamos National Laboratory Report LA-13555-MS, 32 p.

Slate, J.L., Berry, M.E., Rowley, P.D., Fridrich, C.J., Morgan, K.S., Workman, J.B., Young, O.D., Dixon, G.L., Williams, V.S., McKee, E.H., Ponce, D.A., Hildenbrand, T.G., Swadley, W.C., Lundstrom, S.C., Ekren, E.B., Warren, R.G., Cole, J.C., Fleck, R.J., Lanphere, M.A., Sawyer, D.A., Minor, S.A., Grunwald, D.J., Laczniak, R.J., Menges, C.M., Yount, J.C., and Jayko, A.S., 1999, Digital geologic map of the Nevada Test Site and vicinity, Nye, Lincoln, and Clark Counties, Nevada, and Inyo County, California: U.S. Geological Survey Open-File Report 99-554A, 54 p.

Soule', D.A., 2006, Climatology of the Nevada Test Site: National Oceanic and Atmospheric Administration Technical Memorandum SORD 2006-3, 165 p.

Stoller-Navarro Joint Venture, 2004, Integrated analysis report for the single- and multiple-well aquifer testing at Frenchman Flat well cluster RNM-2s, Nevada Test Site, Nevada: Stoller-Navarro Joint Venture Report S-N/99205029 [variously paged].
Stoller-Navarro Joint Venture, 2005, Analysis of hydraulic responses from the ER-6-1 multiple-well aquifer test, Yucca Flat, FY2004 Testing Program, Nevada Test Site, Nye County, Nevada: Stoller-Navarro Joint Venture Report S-N/99205-051 [variously paged].

Thompson, J.L., 1985, Laboratory and field studies related to the radionuclide migration project, October 1 , 1983-September 30, 1984: Los Alamos National Laboratory Progress Report LA-10372-PR, 35 p.

Thompson, J.L., 1999, ed., Laboratory and field studies related to the radionuclide migration project at the Nevada Test Site, October 1, 1997-September 30, 1998: Los Alamos National Laboratory Progress Report LA-13576-PR, 28 p.

Thordarson, William, 1983, Geohydrologic data and test results from well J-13, Nevada Test Site, Nye County, Nevada: U.S. Geological Survey Water-Resources Investigations Report 83-4171, 63 p.

Thordarson, William, Young, R.A., and Winograd, I.J., 1967, Records of wells and test holes in the Nevada Test Site and vicinity (through December 1966): U.S. Geological OpenFile Report 67-218, 26 p.

Townsend, Y.E., and Grossman, R.F., 2000, Nevada Test Site annual site environmental report for calendar year 1999: Bechtel Nevada, Report DOE/NV/11718-463 prepared for the U.S. Department of Energy, Nevada Operations Office [variously paged].

U.S. Army Corps of Engineers, 1951, Log of well no. 1: Los Angeles, Calif., U.S. Engineer Office [variously paged].

U.S. Department of Energy, 1996a, Recompletion report and summary of well history for Water Well 2: Nevada Operations Office, Environmental Restoration Division, Report DOE/NV-436 UC-700 [variously paged].

U.S. Department of Energy, 1996b, Recompletion report and summary of well history for Water Well 3: Nevada Operations Office, Environmental Restoration Division, Report DOE/NV-433 UC-700 [variously paged].

U.S. Department of Energy, 1996c, Recompletion report and summary of well history for Water Well 5a: Nevada Operations Office, Environmental Restoration Division, Report DOE/NV-431 UC-700 [variously paged].

U.S. Department of Energy, 1996d, Recompletion report and summary of well history for Water Well UE-19c: Nevada Operations Office, Environmental Restoration Division, Report DOE/NV-432 UC-700 [variously paged].

U.S. Department of Energy, 2000, United States nuclear tests, July 1945 through September 1992: Nevada Operations Office, Report DOE/NV-209-REV 15, 162 p. 
U.S. Department of Energy, 2004, EPA Farm: National Nuclear Security Administration Nevada Site Office, Report DOE/NV-771, 2 p.

U.S. Department of Energy, 2005, Nevada Test Site guide: National Nuclear Security Administration Nevada Site Office, Report DOE/NV-715, rev. 1, 81 p.

U.S. Department of Energy, 2008, Groundwater protection program plan for the National Nuclear Security Administration Nevada Site Office: National Nuclear Security Administration Nevada Site Office, Report DOE/ NV/25946-557 [variously paged].

Warren, R.G., Sawyer, D.A., Byers, F.M., Jr., and Cole, G.L., 2003, A petrographic, geochemical, and geophysical database, and stratigraphic framework for the southwestern Nevada volcanic field: Los Alamos National Laboratory Report LA-UR-03-1503, 55 p. accessed online September 23, 2008, at http://www.pggdb-swnvf.lanl.gov/.

Wills, C.A., 2004, Nevada Test Site environmental report 2003: Bechtel Nevada, Report DOE/NV/11718-971 prepared for the U.S. Department of Energy, National Nuclear Security Administration Nevada Site Office [variously paged].

Wills, C.A., 2006, Nevada Test Site environmental report 2005: National Security Technologies, LLC, Report DOE/ NV/11718-1214 prepared for the U.S. Department of Energy, National Nuclear Security Administration Nevada Site Office [variously paged].
Wills, C.A., 2007, Nevada Test Site environmental report 2006: National Security Technologies, LLC, Report DOE/ NV/25946-259 prepared for the U.S. Department of Energy, National Nuclear Security Administration Nevada Site Office [variously paged].

Wills, C.A., 2008, ed., Nevada Test Site environmental report 2007: National Security Technologies, LLC, Report DOE/ NV/25946-543 prepared for the U.S. Department of Energy, National Nuclear Security Administration Nevada Site Office [variously paged].

Wilmarth, V.R., Healey, D.L., Clebsch, Alfred, Jr., Winograd, I.J., Zietz, Isidore, and Oliver, H.W., 1959, A summary interpretation of geologic, hydrologic, and geophysical data for Yucca Valley, Nevada Test Site, Nye County, Nevada: U.S. Geological Survey Open-File Report 60-156, 53 p.

Winograd, I.J., and Thordarson, William, 1975, Hydrogeologic and hydrochemical framework, south-central Great Basin, Nevada-California; with special reference to the Nevada Test Site: U.S. Geological Survey Professional Paper 712-C, $126 \mathrm{p}$.

Wood, D.B., 2007, Digitally available interval-specific rocksample data compiled from historical records, Nevada Test Site and vicinity, Nye County, Nevada: U.S. Geological Survey Data Series 297, rev. 2.00, 58 p. (Also available at http://pubs.usgs.gov/ds/2007/297/.)

Wood, D.B., and Reiner, S.R., 1996, Ground-water data for 1990-91 and ground-water withdrawals for 1951-91, Nevada Test Site and vicinity, Nye County, Nevada: U.S. Geological Survey Open-File Report 96-475, 78 p.

Young, R.A., 1972, Water supply for the Nuclear Rocket Development Station at the U.S. Atomic Energy Commission's Nevada Test Site: U.S. Geological Survey Water-Supply Paper 1938, 19 p. 
This page intentionally left blank. 


\section{Appendix A. Database of Groundwater Withdrawal Data and Associated Well Characteristics for the Nevada National Security Site, Nye County, Nevada, 1951-2008}

Groundwater withdrawal data and well characteristic information for 42 wells completed in 33 boreholes on and directly adjacent to the Nevada National Security Site (NNSS) are presented in a Microsoft ${ }^{\odot}$ Excel 2003 spreadsheet. A graphical representation of monthly or annual groundwater withdrawal data and generalized well construction and borehole lithology can be viewed for each well, as well as a site map showing borehole locations ("View data" sheet in the Excel spreadsheet). NOTE: The macros used in this spreadsheet were developed to work in Microsoft ${ }^{\odot}$ Excel 2003. Use of the spreadsheet in newer versions of Excel may result in the data and/or diagrams in the "View data" worksheet to display incorrectly. The wellcharacteristics table ("Well characteristics" sheet in the Excel spreadsheet) contains U.S. Geological Survey site identification number, well name, latitude, longitude, hydrographic area, NNSS area number, land-surface altitude, date well construction was started and completed, hole depth, well depth, bottom of casing, casing diameter, top and bottom of open intervals, primary aquifer (primary water-bearing zone), period of withdrawal, and pump installation and removal dates (if known) for each well. The groundwater withdrawal data ("Data" sheet in the Excel spreadsheet) consist of measured and estimated withdrawals, number of days measured or estimated, and associated remarks and data sources.

Data are available for download at http://pubs.usgs.gov/ds/567/. 
This page intentionally left blank. 
Publishing support provided by the U.S. Geological Survey

Publishing Network, Tacoma Publishing Service Center

For more information concerning the research in this report, contact the Director, Nevada Water Science Center

U.S. Geological Survey

2730 N. Deer Run Road

Carson City, Nevada 89701

http://nevada.usgs.gov/ 


\section{애용}

少

ํㅡㄹ

응



言

s

. 